ANL- 6073

Reactors - General

(TID-4500, 15th Ed.)

AEC Research and.

Development Report

ARGONNE NATIONAL LABORATORY

P. O. Box 299

Lemont, Illinois

\title{
ADVANCED DESIGNS OF MAGNETIC JACK-TYPE CONTROL ROD DRIVE
}

by

Joseph N. Young

Reactor Engineering Division

November, 1959

Operated by The University of Chicago under

Contract $W-31-109-e n g-38$ 


\section{DISCLAIMER}

This report was prepared as an account of work sponsored by an agency of the United States Government. Neither the United States Government nor any agency Thereof, nor any of their employees, makes any warranty, express or implied, or assumes any legal liability or responsibility for the accuracy, completeness, or usefulness of any information, apparatus, product, or process disclosed, or represents that its use would not infringe privately owned rights. Reference herein to any specific commercial product, process, or service by trade name, trademark, manufacturer, or otherwise does not necessarily constitute or imply its endorsement, recommendation, or favoring by the United States Government or any agency thereof. The views and opinions of authors expressed herein do not necessarily state or reflect those of the United States Government or any agency thereof. 


\section{DISCLAIMER}

Portions of this document may be illegible in electronic image products. Images are produced from the best available original document. 
TABLE OF CONTENTS

Page

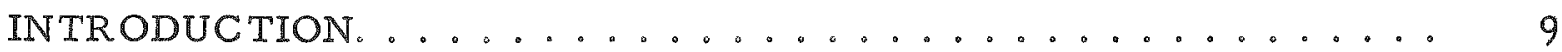

LITERATURE RELATING TO THE MAGNETIC JACK . . . . . . . 9

BRIEF DESCRIPTION OF THE MAGNETIC JACK ........ 10

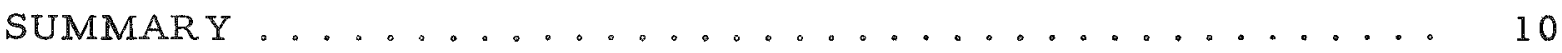

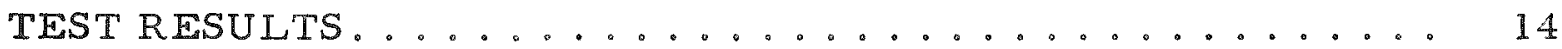

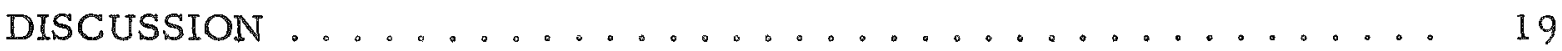

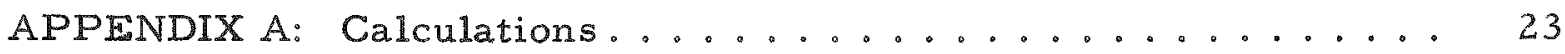

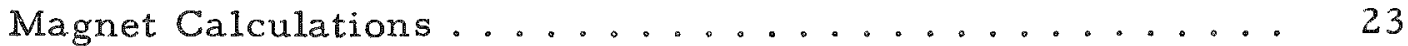

Water Dash Pot Design..................... 28

Antigravity-Scram Control Rod Drive

Using the Magnetic Jack ................ 34

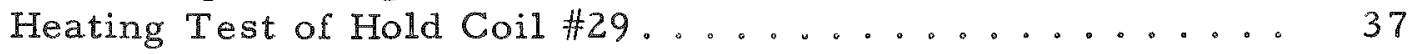

APPENDIX B: Jack Drive for ALPR $(\mathrm{SL}-1) \ldots \ldots . \ldots 1$

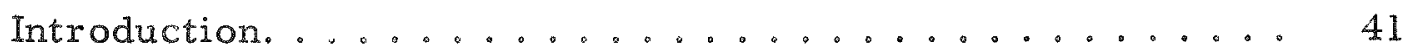

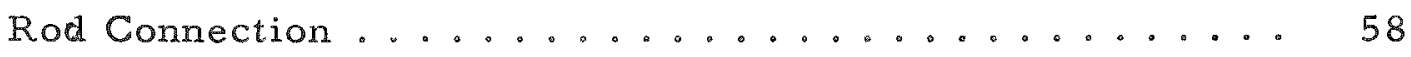

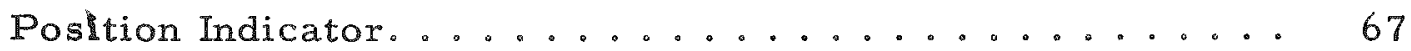

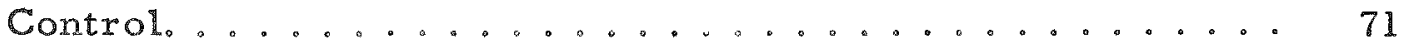

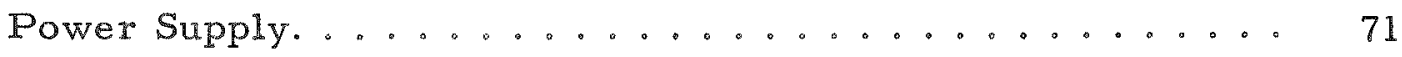

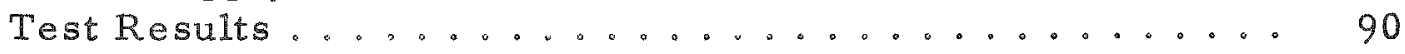

APPENDIX C: Details of the High-pressure and the

EBWR Magnetic Jacks................ 93

Drawing List for the High-Pressure Magnetic

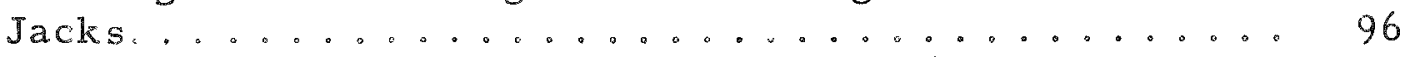

Drawing List for the EBWR Magnetic Jack (29L) ...... 97

APPENDIX D: Position Indicators ............... 111

Light Bulb Type..................... 114

Test Results of the Decade Switch-type Position Indicator. 122

APPENDIX E: Destruction Test of a Model of the Pressure Shell . 127

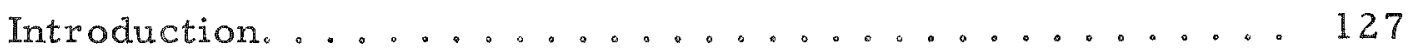

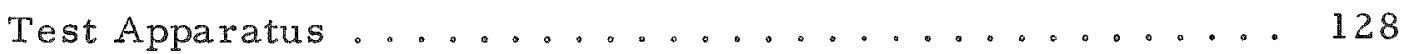

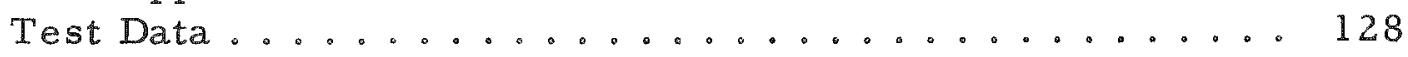

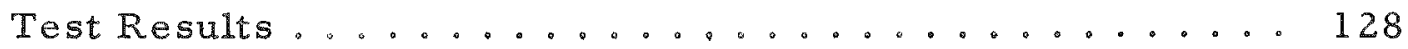

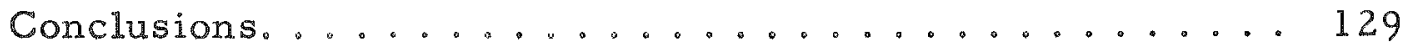

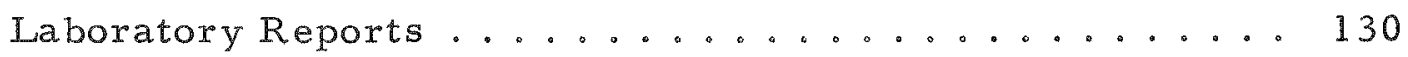

$\operatorname{INDEX} \ldots \ldots \ldots \ldots \ldots \ldots \ldots \ldots$ 


\section{LIST OF FIGURES AND DRA WINGS}

Page

Specifications of Two Magnetic Jacks. . . . . . . . . . . . . 12

EBWR Magnetic Jack (29L) . . . . . . . . . . . . . . . 13

Control and Power Supply .................. 15

Rectifier (Silicon). . . . . . . . . . . . . . . 16

Test of EBWR Magnetic Jack (29L). . . . . . . . . . . 17

Insulating Flange $\ldots \ldots \ldots \ldots \ldots \ldots \ldots \ldots \ldots \ldots \ldots \ldots \ldots \ldots$

Move Magnet, Jack \#29 H. . . . . . . . . . . . . . . . . 23

Grip-Magnet, Jack \#29 H . . . . . . . . . . . . . . . . . 24

Hold Magnet, Jack $\# 29$ L .................... 25

Grip and Hold Magnet, Jack \#27 . . . . . . . . . . . . 27

Sample Force Curve.......................... 32

Dash Pot, Schematic Drawing ............... 33

Heating Test of Hold Coil \#29................ 38

Thermal Coefficient of Electrical Resistance for Copper

Magnetic Wire....................... 39

Typical Heat Dissipation Curve. . . . . . . . . . . . . 40

Short-length Magnetic Jack (\#27). . . . . . . . . . . . . . . 42

Magnetic Jack \#27 . . . . . . . . . . . . . . . . . 43

Magnetic Jack \#27 (RE-1-20471-D) ............... 44

Coil Terminal Connections. . . . . . . . . . . . . . . . 45

Move Coil Assembly (RE-1-21538-A) . . . . . . . . . . . 46

Grip Coil Assembly $(R E-1-21541-B) \ldots \ldots \ldots \ldots . \ldots \ldots 4$

End Plate $(R E-1-21539-B) \ldots \ldots \ldots \ldots \ldots \ldots \ldots$

Move Coil Ring (RE-1-24235-A) . . . . . . . . . . . . 48

Move Coil $(\mathrm{RE}-1-24236-\mathrm{B}) \ldots \ldots \ldots \ldots \ldots . \ldots \ldots 4$

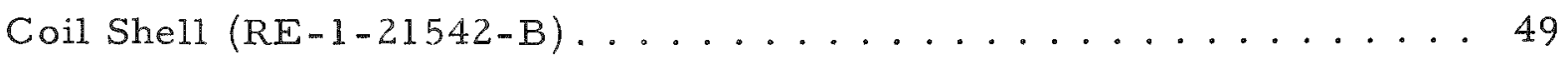

Terminal Post $(R E-1-21540-A) \ldots \ldots \ldots \ldots \ldots \ldots$

Grip-Coil $(R E-1-24237-B) \ldots \ldots \ldots \ldots . \ldots \ldots 49$

Flanged Tube $(R E-1-20386-B) \ldots \ldots \ldots \ldots \ldots$ 
Flanged Plate $(\mathrm{RE}-1-23430-\mathrm{B}) \ldots \ldots \ldots \ldots$

Coil Clamp $(\mathrm{RE}-1-20387-\mathrm{A}) \ldots \ldots \ldots \ldots \ldots$

"S" Connector $(\mathrm{RE}-1-22432-\mathrm{A}) \ldots \ldots \ldots \ldots \ldots$

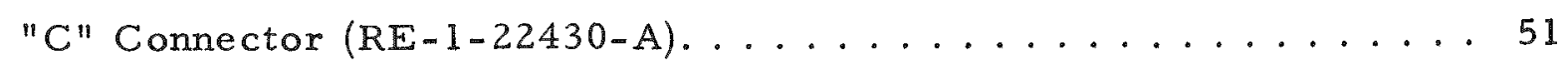

"L" Connector $(\mathrm{RE}-1-22431-\mathrm{A}) \ldots \ldots \ldots \ldots \ldots$

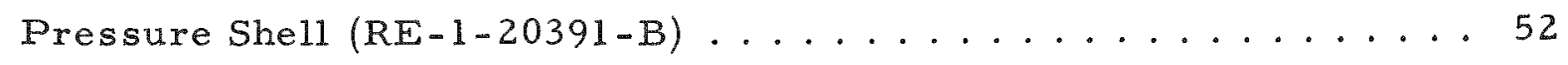

Large End $(\mathrm{RE}-1-20396-\mathrm{B}) \ldots \ldots \ldots \ldots \ldots$

Large End Pipe $(\mathrm{RE}-1-20397-\mathrm{B}) \ldots \ldots \ldots \ldots 2$

Large End Flange $(\mathrm{RE}-1-20398-\mathrm{A}) \ldots \ldots \ldots \ldots$

Small End $(R E-1-20392-B) \ldots \ldots \ldots \ldots$

Small End Plug $(R E-1-20393-A) \ldots \ldots \ldots$

Small End Pipe $(R E-1-20394-A) \ldots \ldots \ldots 3$

Small End Flange $(\mathrm{RE}-1-20395-\mathrm{B}) \ldots \ldots \ldots \ldots$

Holder $(\mathrm{RE}-\mathrm{I}-20399-\mathrm{B}) \ldots \ldots \ldots \ldots \ldots$

Weldment $(\mathrm{RE}-1-20402-\mathrm{B}) \ldots \ldots \ldots \ldots \ldots \ldots$

Fnd $(R E-1-20377-B) \ldots \ldots \ldots \ldots \ldots \ldots$

Armature $(R E-1-20400-B) \ldots \ldots \ldots \ldots$

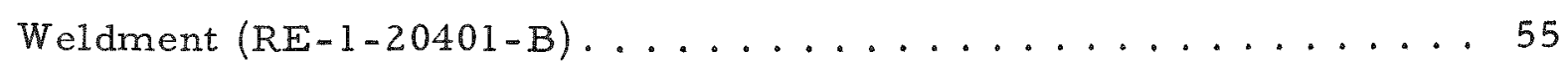

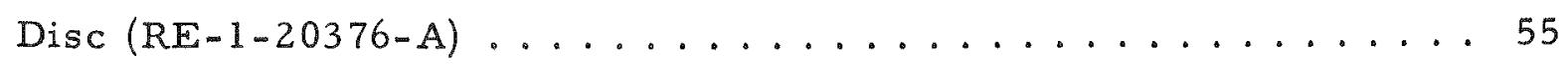

Nonmagnetic Sleeve $(R E-1-20381-A) \ldots \ldots \ldots 6$

Nonmagnetic Washer $(\mathrm{RE}-1-20380-\mathrm{A}) \ldots \ldots \ldots$

$\operatorname{Shim}(\mathrm{RE}-1-20379-\mathrm{A}) \ldots \ldots \ldots \ldots \ldots$

Cushion Washer $(\mathrm{RE}-1-20378-\mathrm{A}) \ldots \ldots \ldots \ldots$

Drive $\operatorname{Rod}(\mathrm{RE}-1-20177-\mathrm{B}) \ldots \ldots \ldots \ldots \ldots$

P. I. $\operatorname{Rod}(\operatorname{RE}-1-20383-A) \ldots \ldots \ldots \ldots \ldots$

Flange Ring $(\mathrm{RE}-1-20382-\mathrm{B}) \ldots \ldots \ldots \ldots \ldots$

Coil Spacer $(\mathrm{RE}-1-20388-\mathrm{A}) \ldots \ldots \ldots \ldots \ldots$

Rod Connection Assembly $(\mathrm{RE}-1-22614-\mathrm{F}) \ldots \ldots 61$

Lift Tool $(R E-1-24181-B) \ldots \ldots \ldots \ldots 2$ 


\section{LIST OF FIGURES AND DRAWINGS}

Page

Adapter Flange $(R E-1-22615-B) \ldots \ldots \ldots 2$

Spring Seat Tube $(R E-1-22616-B) \ldots \ldots \ldots 2$

Filler Tube $(R E-1-22617-B) \ldots \ldots \ldots \ldots$

Lock Tube $(\mathrm{RE}-1-22618-\mathrm{B}) \ldots \ldots \ldots 3$

Belleville Spring $(\operatorname{RE}-1-22619-A) \ldots \ldots 63$

Support Washer $(R E-1-22620-A) \ldots \ldots \ldots 4$

Spacer $(R E-1-22621-A) \ldots \ldots \ldots 4$

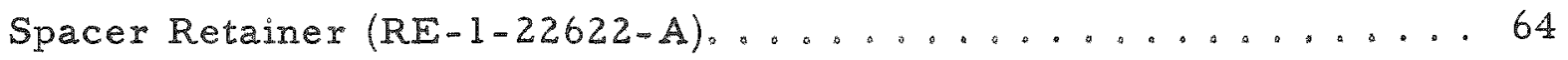

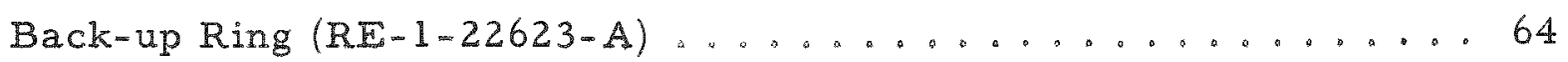

Outer Tube $(\mathrm{RE}-1-22624-\mathrm{B} ; 22625-\mathrm{B} ; 22626-\mathrm{A}) \ldots \ldots 65$

Extension Rod (RE-1-22627-B:22628-A:22629-A:22630-B;

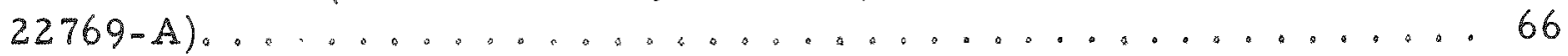

Linear Scale-type Position Indicator Coil Assembly . . . . . . . . 68

ALPR P. I. Power Supply (One Drive) ................ 69

ALPR P.I. Selector (One Drive)..................... 70

ALPR P. I. Meter and Lights (One Drive) .............. 70

Power Supply for One Magnetic Jack ................. 72

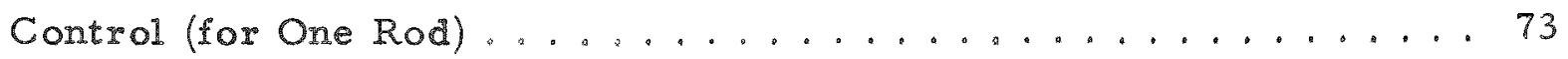

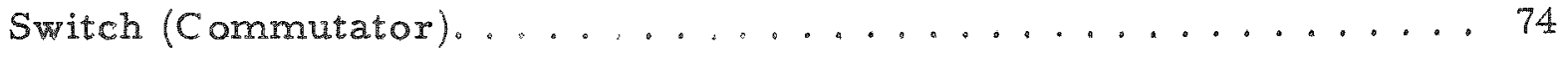

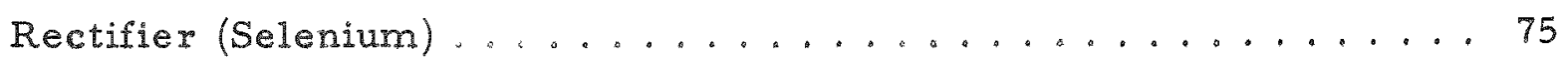

Commutator Switch Assembly $\left(\operatorname{RE}_{-1}-23474-\mathrm{D}\right) \ldots \ldots 76$

Commutator Switch Rotor Parts $(\mathrm{RE}-1-23472-\mathrm{D}) \ldots \ldots . \ldots 77$

Commutator Switch, Mounting Parts (RE-1-23473-D) ........78

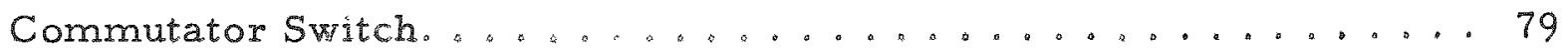

ALPR Magnetic Jack Control Rod Drive, Electrical Panel...... 81

Control for 4 Outer Rods and 1 Center Rod.............8 82

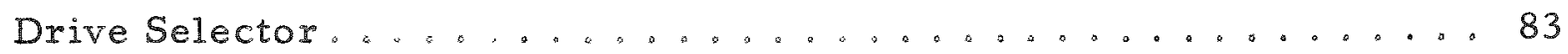

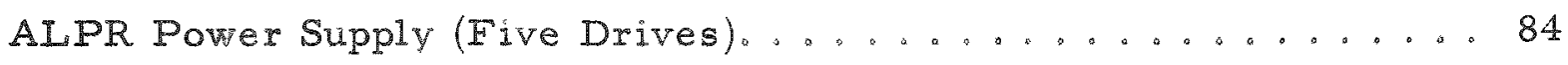

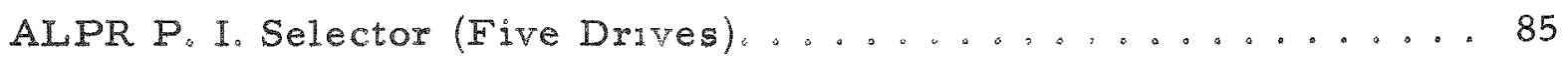


LIST OF FIGURES AND DRAWINGS

Page

ALPR P.I, Meters and Lights (Five Drives)........... 86

Electrical Panel for Five Jack Drives, Front View . . . . . . . . . . 88

Electrical Panel for Five Jack Drives, Back View . . . . . . . . . 89

High-pressure Magnetic Jack (29 H) Assembly . . . . . . . . . . . 93

Low-pressure Bottom Drive Magnetic Jack (EBWR) (29 L) Assembly with Coils Removed ......................... 94

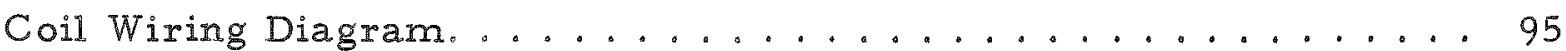

Pressure Shell, High-pressure (RE-1-31081-A) . . . . . . . . 98

Flange Ring, High-pressure (RE-1-31084-A) . . . . . . . . . 98

Armature,Grooved (RE-1-31083-A) ............... 98

Chamber Plug $(\mathrm{RE}-1-31082-\mathrm{A}) \ldots \ldots \ldots \ldots$

Pressure Shell Body, High-pressure (RE-1-31085-A) . . . . . . . . 99

Body Head $(\mathrm{RE}-1-31088-\mathrm{A}) \ldots \ldots \ldots 9$

Body Flange, High-pressure $(\mathrm{RE}-1-31086-\mathrm{A}) \ldots \ldots 99$

Body Tube, High-pressure $(R E-1-31087-A) \ldots \ldots 99$

Pressure Shell Extension, High-pressure (RE-1-31089-A). . . . . 100

Extension Pipe $(R E-1-31092-A-1) \ldots \ldots 100$

Extension Cap $(R E-1-31092-A-2) \ldots \ldots \ldots 0$

Extension Tube, High-pressure $(R E-1-31091-A) \ldots \ldots 0$

Extension Flange $(R E-1-31090-A) \ldots \ldots \ldots 0$

Drive Rod, Notched $(R E-1-18795-B) \ldots \ldots \ldots 1$

Rod Connector $(R E-1-17894-A) \ldots \ldots \ldots 1$

Filler $\operatorname{Rod}(\operatorname{RE}-1-18799-A) \ldots \ldots \ldots 10 \ldots \ldots$

Nonmagnetic Sleeve $(\mathrm{RE}-1-31093-\mathrm{A}-1) \ldots \ldots \ldots 2$

Cushion Washer $(R E-1-31093-A-2) \ldots \ldots \ldots 2$

$\operatorname{Shim}(R E-1-31093-A=3) \ldots \ldots \ldots \ldots 2$

Large Coil Spacer $(\mathrm{RE}-1-31094-\mathrm{A}-1) \ldots \ldots 102$

Small Coil Spacer $(R E-1-31094-A-2) \ldots \ldots 102$

Large Coil Clamp $(\mathrm{RE}-1-31094-\mathrm{A}-3) \ldots \ldots \ldots 2$ 


\section{LIST OF FIGURES AND DRAWINGS}

Page

Small Coil Clamp $(\mathrm{RE}-1-31094-\mathrm{A}-4) \ldots \ldots \ldots \ldots \ldots 2$

Move Coil, Potted (RE-1-31095-A) ............... 103

Move Coil End Plate $(R E-1-31096-A) \ldots \ldots \ldots \ldots 103$

Move Coil Ring (RE $1-31097-A) \ldots \ldots \ldots . \ldots \ldots 3$

Grip Coil, Potted (RE-1-31098-A) . . . . . . . . . . . . 104

Grip Coil End Plate (RE-1-31099-A-1). . . . . . . . . . . 104

Grip Coil Ring (RE-1-31099-A-2) . . . . . . . . . . . . 104

Grip Coil (RE-1-31100-A) . . . . . . . . . . . . . . . . 104

Hold Coil End Plate $(R E-1-31102-A-1) \ldots \ldots \ldots \ldots 105$

Hold Coil Ring $(R E-1-31102-A-2) \ldots \ldots \ldots \ldots \ldots$

Hold Coil, Potted $(R E-1-31101-A) \ldots \ldots \ldots \ldots$. . . . . . . .

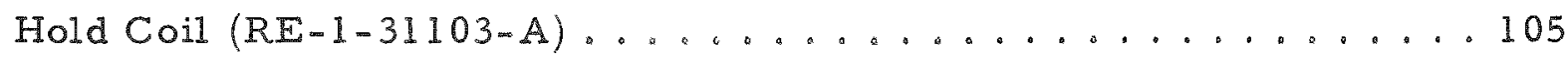

Pressure Shell Body, Low-pressure (RE-1-31105-A) . . . . . . 106

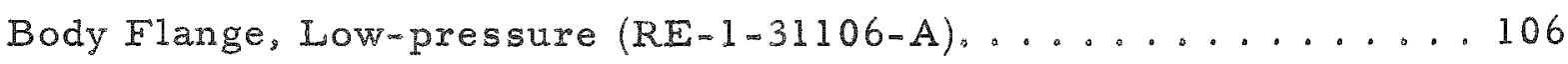

Body Tube, Low-pressure $(R E-1-31107-A) \ldots \ldots \ldots 106$

Flange Ring, Low pressure $(R E-1-31113-A) \ldots \ldots \ldots 106$

Pressure Shell Extension Low-pressure (RE-1-31108-A) . . . . . . 107

Extension Tube, Low-pressure $(R E-1-31109-A) \ldots \ldots \ldots \ldots 107$

Armature $(R E-1-31110-A) \ldots \ldots \ldots \ldots \ldots$. . . . . . . . . . . .

Dirt Shield $(R E-1-31117-A) \ldots \ldots \ldots \ldots \ldots \ldots$

Drive $\operatorname{Rod}(R E-1-31111-A-1) \ldots \ldots \ldots \ldots$. . . . . . . . . . . . . . . . .

Rod Connection $(R E-1-31111-A-2) \ldots \ldots \ldots \ldots \ldots$. . . . . . . . . .

Rod Retainer $(R E-1-31111-A-3) \ldots \ldots \ldots \ldots$. . . . . . . . .

Valve Body $(R E-1-31115-A-1) \ldots \ldots \ldots 109$

Valve Stem $(R E-1-31115-A-2) \ldots \ldots \ldots \ldots$. . . . . . . . . . . .

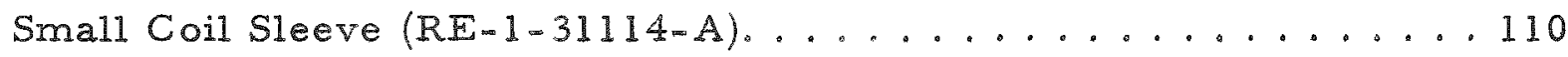

Large Coil Sleeve $(R E-1-31116-A) \ldots \ldots \ldots \ldots \ldots \ldots 10$

Position Indicator Coil $(R E-1-21409=B) \ldots \ldots \ldots 113$

Light Bulb-type Position Indicator (Schematic) . . . . . . . . . d15 
LIST OF FIGURES AND DRAWINGS

Page

Voltage Variation across Coil. .................. 116

Light Bulb-type Position Indicator. . . . . . . . . . . . 117

Automatic Meter-type Position Indicator .............. 118

Automatic Meter-type Position Indicator Pane1 ............. I19

Automatic Meter Position Indicator, Transmitter Diagram . . . . . 120

Automatic Meter Position Indicator, Panel Diagram.......... 121

Automatic Meter Position Indicator, Coil Diagram. . . . . . . . . 121

Decade Switch-type Position Indicator (RE-2-30138-C) . . . . . 123

Decade-type Position Indicator, Coil Diagram. . . . . . . . . . . 124

Decade Switch-type Position Indicator Panel. . . . . . . . . 125

Large Crack at Flanged End. . . . . . . . . . . . . 136

End View of Failure ..................... 137

Side View of Failure....................... 138

Side View of Failure. . . . . . . . . . . . . . . . . . 139

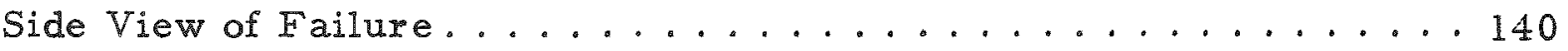

Side View of Failure ....................... . . 141

Side View ............................... 142

Bottom View - Disassembled .................. 143

Flange and Gasket - Disassembled . . . . . . . . . . . . . 144

Model Used in Tests 1 and 2.................... 145

Model Used in Test $3 \ldots \ldots \ldots \ldots$

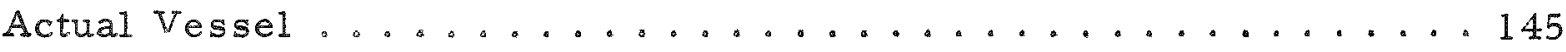

Test Model Flange Assembly . . . . . . . . . . . . . . . . 146 


\section{INT RODUCTION}

The magnetic jack is a device for positioning the control rods in a nuclear reactor, especially in a reactor containing water under pressure. Magnetic actuation precludes the need for shaft seals and eliminates the problems associated with mechanisms operating in water.

This report covers the developments made since the writing of a previous report, ANL-5768 (December 1957). The index at the end of this report covers this report and also ANL-5768.

\section{LITERATURE RELATING TO THE MAGNETIC JACK}

J. N. Young, Magnetic Jack - A New Control Drive Mechanism, Nucleonics, 15 (6), $118-123$ (June 1957).

J. N. Young, Design and Performance Characteristics of Magnetic JackType Control Rod Drive, ANL-5768 (December 1957).

Westinghouse Magnetic Rod Drives Description (advertisement), Nucleonics, 17 (6), 129 (June 1959).

Patent number 2,803,761, which is the improved type discussed in this report.

Patent number 2,831,990, which is the mechanical gripper type.

Annual Technical Progress Report AEC Unclassified Programs Fiscal Year 1959, NAA-SR-3850, page IV-12 thru IV-16 (Atomics International).

J. D. Howell, OMR Control-Safety Rod Component Development Tests, NAA-SR-3172 (Atomics International) (September 1959).

The following drawings may be obtained from the Technical Information Service Extension, P. O. Box 1001 , Oak Ridge, Tennessee, attn: Engineering Sales:

\begin{tabular}{|c|r|c|l|}
\hline AEC No. & Price & ANL No. & \\
\hline CAPE-34-21 & $\$ 2.48$ & $\mathrm{RE}-1-18892-\mathrm{F}$ & control rod \\
CAPE-34-22 & 0.32 & $\mathrm{RE}-1-17892-\mathrm{B}$ & connection \\
CAPE-34-23 & 0.32 & $\mathrm{RE}-1-17893-\mathrm{B}$ & (round rod, sma11 \\
CAPE-34-25 & 0.16 & $\mathrm{RE}-1-17895-\mathrm{A}$ & diameter type) \\
CAPE-34-26 & 0.16 & $\mathrm{RE}-1-17897-\mathrm{A}$ & March, 1956 \\
$\mathrm{CAPE}-34-36$ & 0.16 & $\mathrm{RE}-6-19155-\mathrm{A}$ & \\
\hline $\mathrm{CAPE}-34-30$ & 0.32 & $\mathrm{RE}-1-19093-\mathrm{B}$ & control and \\
CAPE-34-31 & 0.32 & $\mathrm{RE}-1-19096-\mathrm{B}$ & power supply, \\
CAPE-34-32 & 0.16 & $\mathrm{RE}-6-19125-\mathrm{A}$ & (relay type) \\
$\mathrm{CAPE}-34-33$ & 0.16 & $\mathrm{RE}-1-19126-\mathrm{A}$ & Oct. 1956 \\
CAPE-34-34 & 0.16 & $\mathrm{RE}-6-19127-\mathrm{A}$ & \\
CAPE-34-35 & 0.16 & $\mathrm{RE}-7-17995-\mathrm{A}$ & \\
\hline
\end{tabular}


The magnetic jack control rod drive is an hermetically sealed system which eliminates the problems associated with mechanisms operating in water. It consists of a pressure shell, four sets of external stationary magnet coils (hold, grip, lift, pull down) and one internal moving part (armature) that imparts linear motion to a cluster of rods (drive rods).

The drive rods fit loosely in the center of the jack. Applying current to the hold coils causes the rods to adhere to the wall of the pressure shell; the application of current to the grip coils causes the rods to adhere to the bore of the armature. Energizing the lift coil moves the armature to the top end of the chamber and energizing the pull down coil moves the armature to the bottom end of the chamber. Thus, by switching the coils off and on in the proper sequence, the drive rods are moved in steps. If only the hold coil is energized, the rods are held firmly in position. Deenergizing all of the coils allows the rods to drop, thus scramming the reactor.

Although the usual step length (about 0.1 in.) is set in assembly by the amount of axial clearance that the armature has in the chamber, the rods may be moved in extra large steps in the down direction and in extra fine steps (about 0.006 in.) in either direction. The large step length is accomplished by dropping and catching the rods with the hold magnet. The small step is accomplished by switching off the lift magnet and letting the cushion washer do the lifting. The cushion washer is a stiff belleville spring which is located at the end of the armature.

The only drawback in the use of this rod drive at Argonne has been the lack of a positive and precise position indicator which is required for experimental work. For reactors which are primarily used for the production of power, simple magnetic position indicators are adequate. For experimental work, some fairly precise magnetic position indicators have been developed recently. One is a simple device which requires several operations to obtain a close reading; another is a complicated one which is easy to read.

\section{SUMMARY}

There continues to be no mechanical problems with the jack; consequently there have been no basic changes.

Jacks \#24 and \#27 have been modified to provide a more durable coil connection. Instead of fastening the ends of the coil wire to a terminal strip, the coils now have nickel terminal posts which are an integral part of the coil.

\footnotetext{
*A more detailed description is given in ANL-5768.
} 
Jack \#24 was modified further to provide a universal control rod drive for pressures up to 2600 psi. Jack \#29 $\mathrm{H}$ is the high-pressureversion. A short model of the pressure shell of Jack $29 \mathrm{H}$ was pressure tested to destruction (See appendix E).

Jack \#29 L is designed for lower pressures. The design for lower pressure makes possible the use of coil sleeves which facilitate installation of preassembled coil assemblies. This is especially desirable for below-the-reactor applications. The internal parts of Jack $29 \mathrm{~L}$ were slightly modified to minimize the possibility of radioactive dirt collecting in the jack. A special blow-down valve at the bottom is used to remove the dirt that falls thru the drive. Jack \#29 L has been built, tested, and will be installed in EBWR.

Five type \#27 magnetic jacks have been built and tested; one of these will be installed in ALPR. Parts are on hand for a sixth unit, which is a spare. This drive system is described in detail in appendix $B$. It was found necessary to increase the chrome plate thickness of Jack \#27 rods from $0.002 \mathrm{in}$. to $0.006 \mathrm{in}$. This decreases the amount of residual magnetism so that the rod is freer to drop. Residual magnetism is more of a problem with large-diameter hold magnets such as in Jack \#27 than with small-diameter hold magnets such as in Jack \#29. It was also necessary to increase the thickness of the nonmagnetic sleeves to reduce the unbalanced radial forces on the armature and thereby reduce wear. The test described on page 90 caused a small amount of wear which indicates that there will be practically no wear with the thicker sleeve. Radial forces are more of a problem with a short-length armature such as in Jack \#27 than with a long armature such as in Jack \#29.

The following is an approximate manufacturing cost breakdown of the EBWR Magnetic Jack (\#29 L):

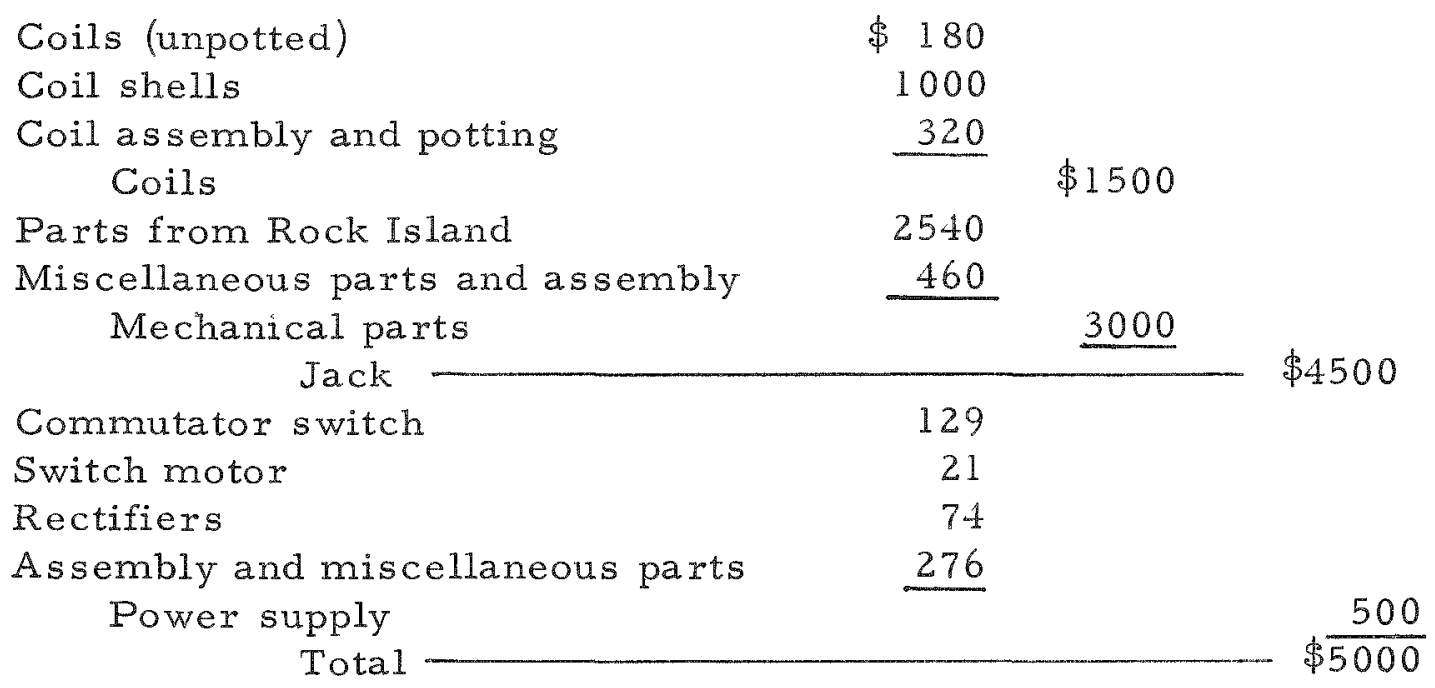




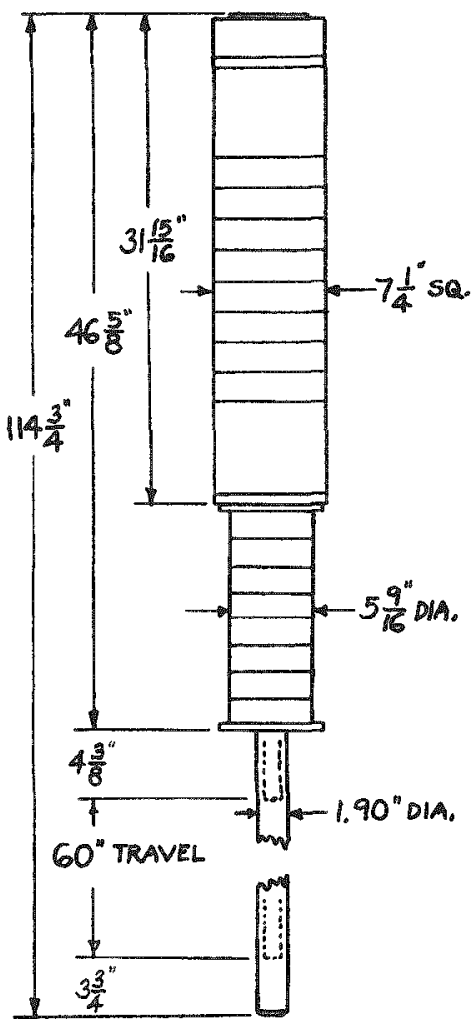

\begin{tabular}{|c|c|c|c|}
\hline & & $100^{\circ} \mathrm{F}$ & $350^{\circ} \mathrm{F}$ \\
\hline DESIGM PRESSURE & P.S.I. & 1120 & 1025 \\
\hline MAXIMUM CAPACITY & 5), LES. & 580 & 490 \\
\hline RATED CAPACITY, & LBS. & 190 & 160 \\
\hline POWER FOR MOLDING, & WATTS & 200 & 140 \\
\hline POWER FOR MOVIMG, & WATTS & 1470 & 980 \\
\hline
\end{tabular}

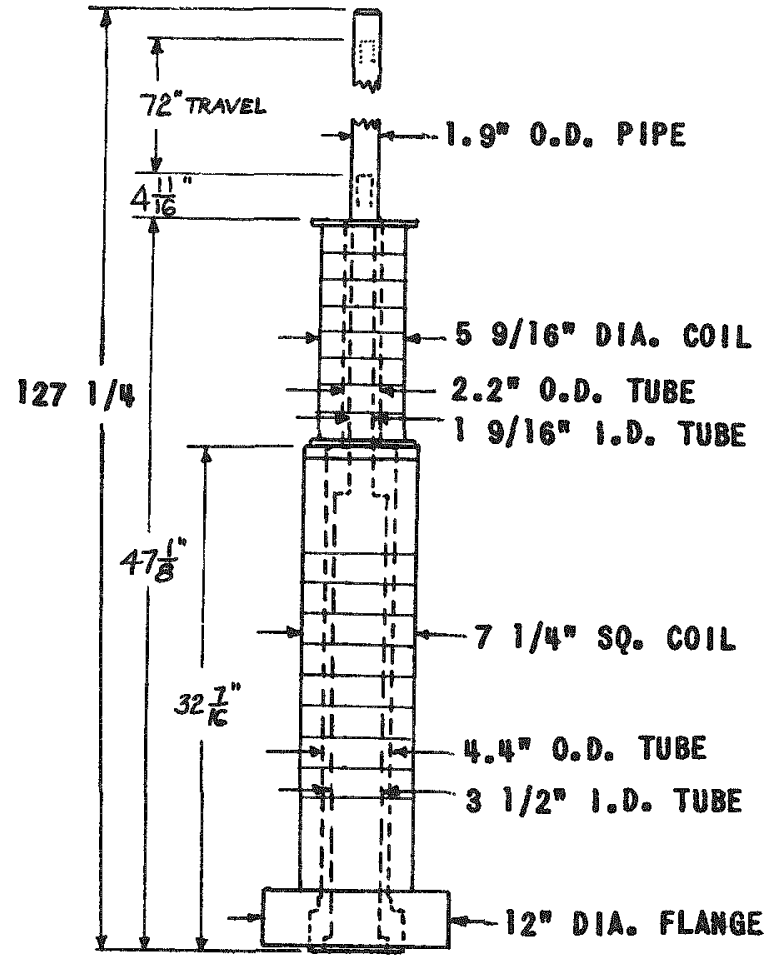

\begin{tabular}{|c|c|c|c|}
\hline & \multicolumn{2}{|c|}{$100^{\circ} \mathrm{F} 350^{\circ} \mathrm{F}$} \\
\hline DESION PRESSURE & P.S.1. & 2800 & 2600 \\
\hline MAXIMUM CAPACITY(F= & 1.LBS. & 580 & 490 \\
\hline RATED CAPACITY, & LBS. & 190 & 160 \\
\hline POWER FOR HOLDING. & WATTS & 200 & 140 \\
\hline POWER FOR MOVING, & WATTS & 1470 & 980 \\
\hline
\end{tabular}

\section{LOW PRESSURE BOTTOM DRIVE MAGNETIC JACK (EBWR) (22L)}

HI GH PRESSURE

TOP DRIVE

MAGNETIC JACK 

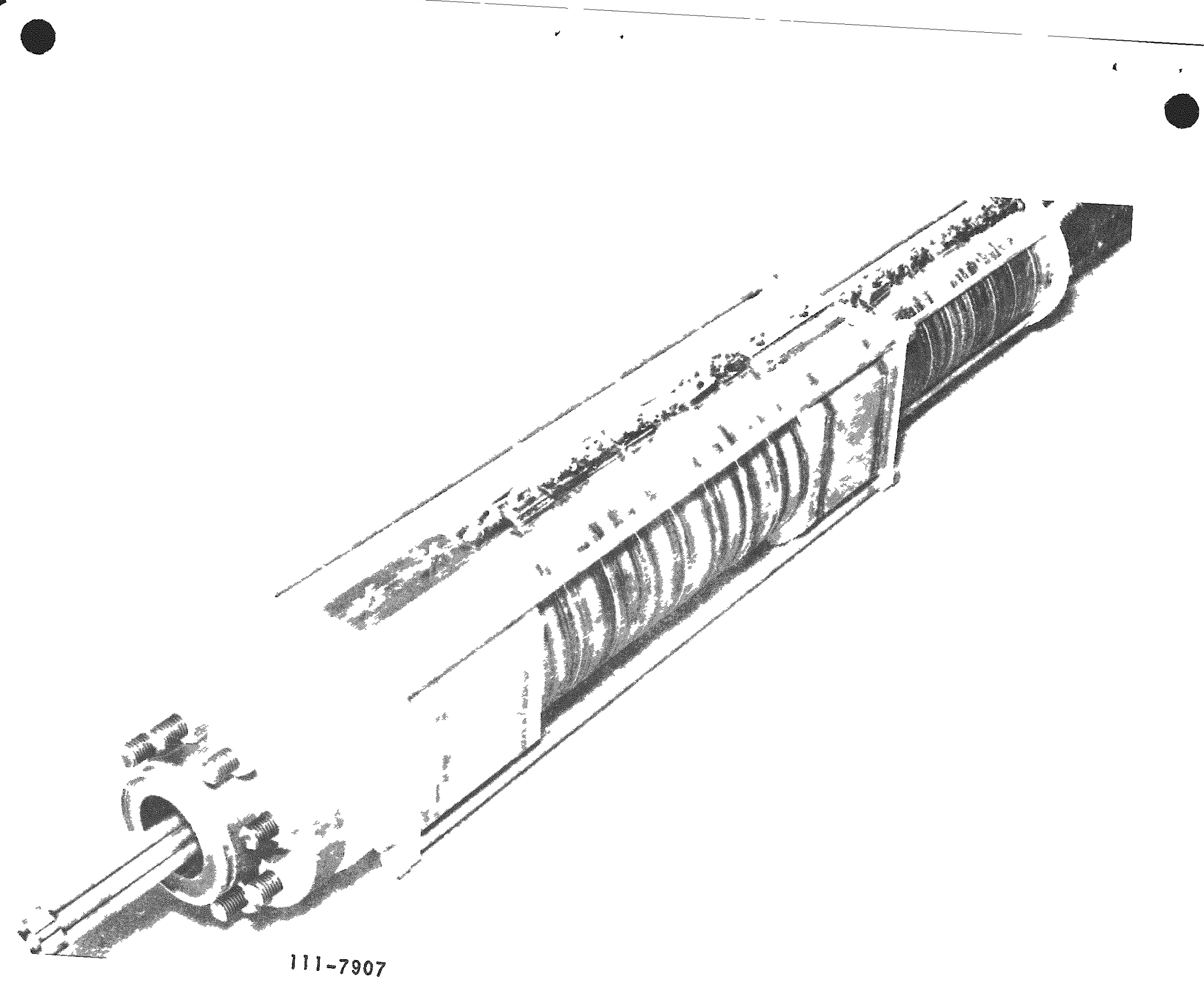

EBWR MAGNETIC JACK (29L) 
The control system has been simplified and designed so that existing reactor controls may be used to control the magnetic jack (see page 15 and appendix B). A new feature is a switch located on the control panel for switching from the usual coarse step of about 0.1 in. to a fine step of about 0.006 in.

The power supply has been simplified and made smaller by using a commutator-type switch instead of the cam-operated microswitches and relays, and by using silicon rectifiers (see page l6) instead of selenium rectifiers (appendix $B$ ). The silicon rectifiers are more efficient, smaller and cheaper but not quite as reliable as the selenium rectifiers. The control and power supply fit on a $17 \times 10$ in. chassis and a $19 \times 7$ in. panel (see page 15).

Three new variations of the magnetic position indicator were built and successfully tested (see appendix D). One is an automatic version of the position indicator described in ANL-5768. The rod position is read directly on a meter which has dial numbers which automatically change when the rod moves from one 3-in. coil range to the next. The second one gives linear indication on a long-scale DC milliammeter. This is accomplished by special spacing of the coils. The third one consists of two selector switches, a meter and a series of coils with one-inch spacing. The first selector switch reads tens of inches, the second selector switch reads inches and the meter reads tenths of inches. Another meter is used across the series of coils to give the approximate position.

\section{TEST RESULTS}

Test results, in addition to those shown below, are listed in the Table of Contents.

The curves on page 17 show decreased lift slippage as the effect of removing the last trace of lubrication and of forming an iron oxide film. This occurs after a new jack is run for a while. This test was made on the EBWR jack (\#29 L) at room temperature and with water open to the atmosphere. The measurements were taken while the jack was cold, but, during most of the operating time, the jack was at about $180 \mathrm{~F}$.

A series of tests were made to determine the equilibrium temperatures of the drive with various cooling methods. The tests were made with the ALPR jack (\#27-2) mounted on a vessel containing water at $422^{\circ} \mathrm{F}$ (300 psig). To simulate a boiling reactor, the top half of the vessel contained saturated steam. To simulate a pressurized reactor, the water level was raised so that there was little or no steam space. A truly pressurized. system might give slightly lower drive temperatures. The ambient temperature was $80^{\circ} \mathrm{F}$. The cooling water was 0.10 gallons per minute of $100^{\circ} \mathrm{F}$ water injected at the flange just below the drive. The hold coils were turned 


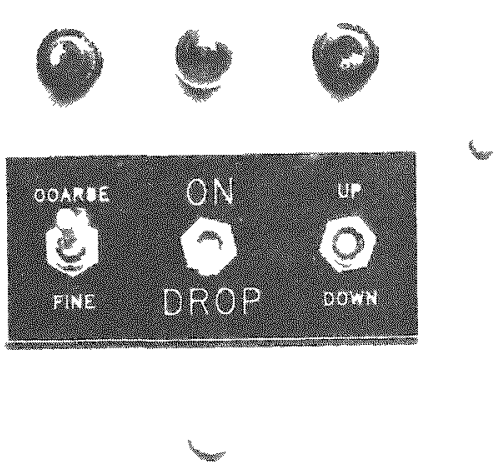

$111-7505$

FRONT VIEW

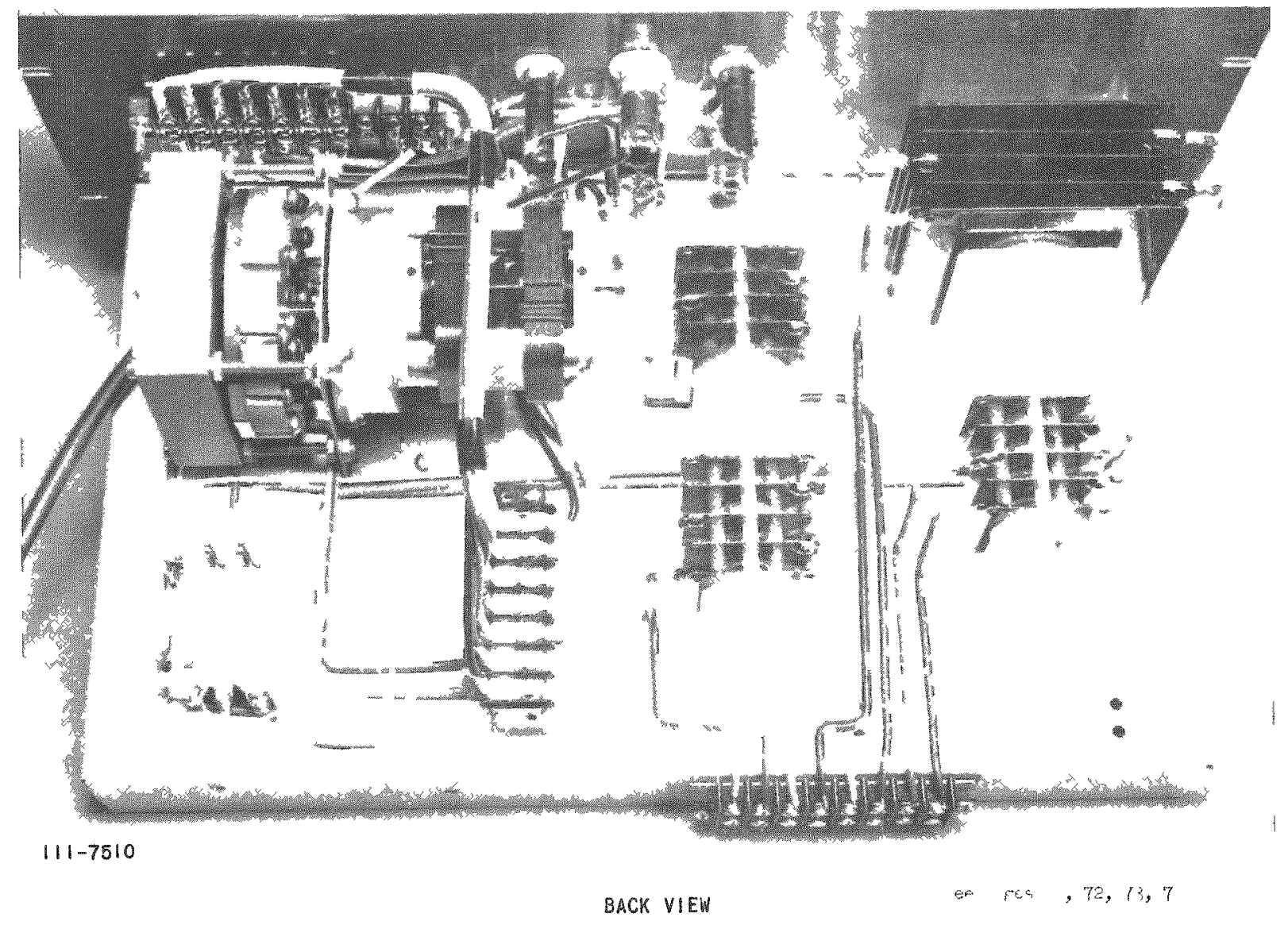

CONTROL AND POWER SUPPLY 


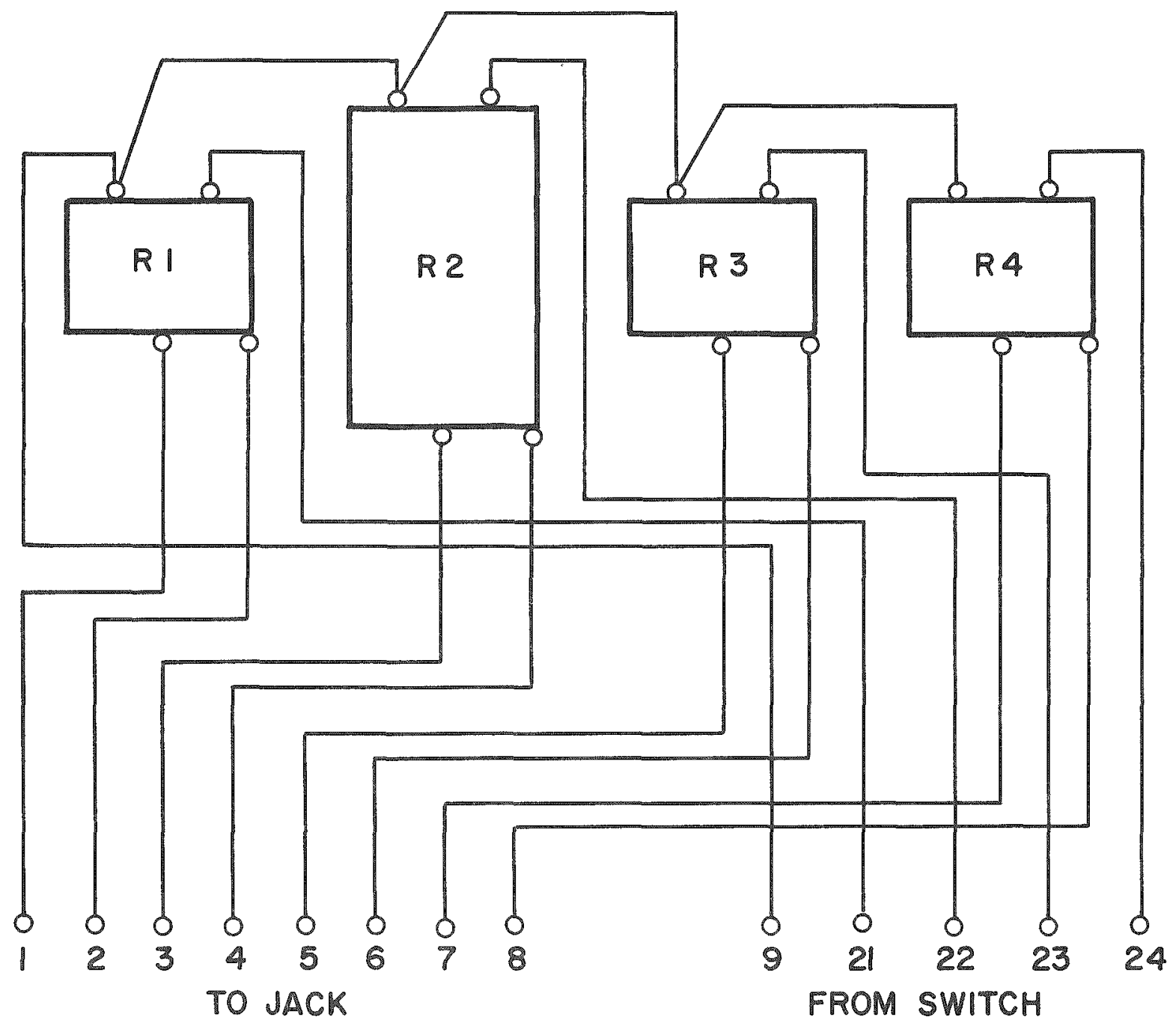

\begin{tabular}{|l|l|}
\hline RI,R3,R4 & SILICON RECTIFIER, 5A., 125 VDC, BRIDGE \\
\hline R2 & SILICON RECTIFIER, 15A., I25 VDC, BRIDGE \\
\hline
\end{tabular}

RECTIFIER (SILICON)

BACK AND TOP VIEW 


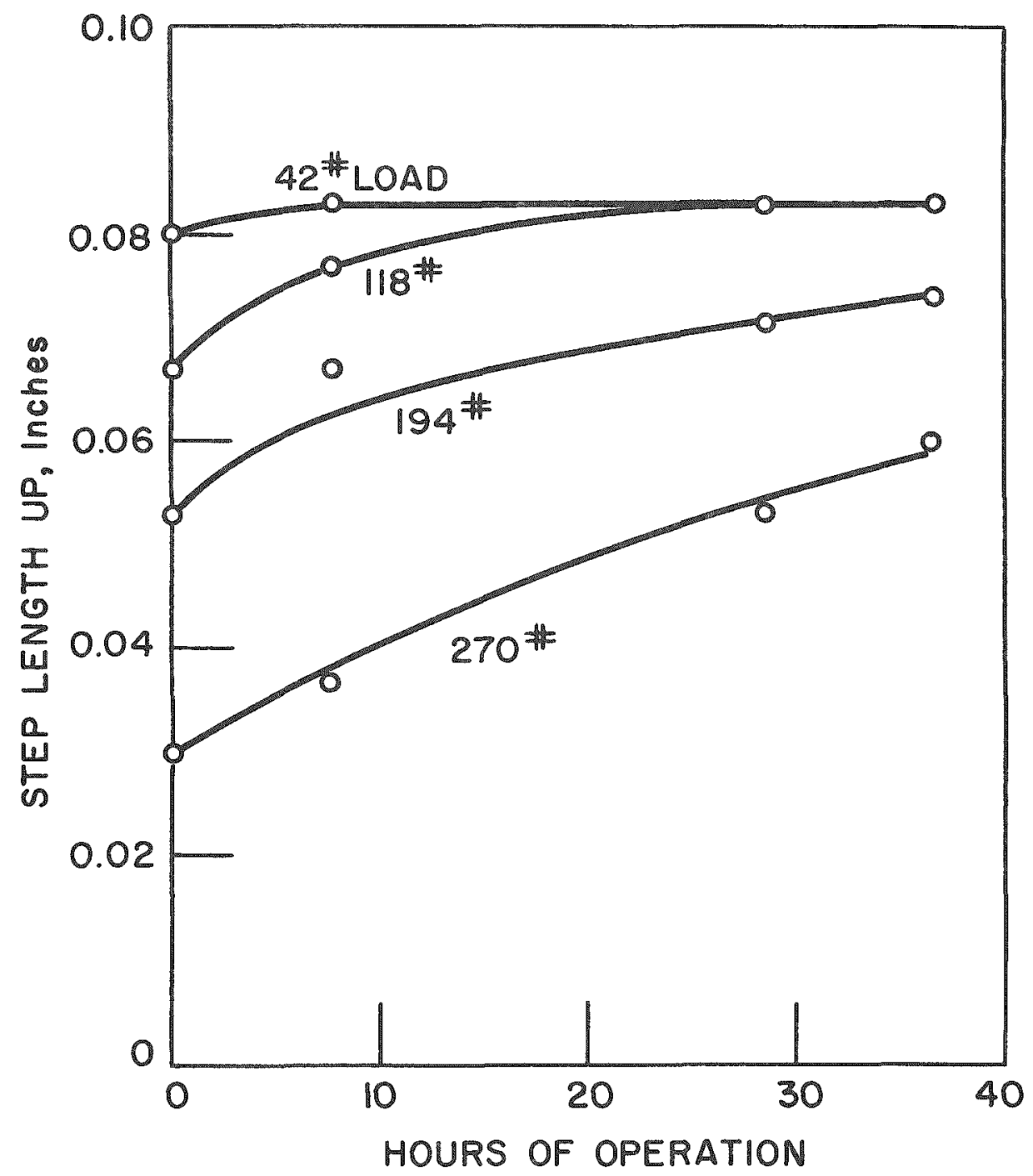

TEST OF EBWR MAGNETIC JACK(29L) 
on during the test. The thin flange consisted of the flange shown on page 62 with a water inlet hole added and with a sleeve which reduced the $1 \frac{3}{4}$ in. bore to a $1 \frac{1}{2}$ in. bore. This sleeve gave a smalle $\mathrm{r}$ clearance for the drive rod and thus kept water in and steam out of the jack with a moderate amount of cooling. The insulating flange is shown below.

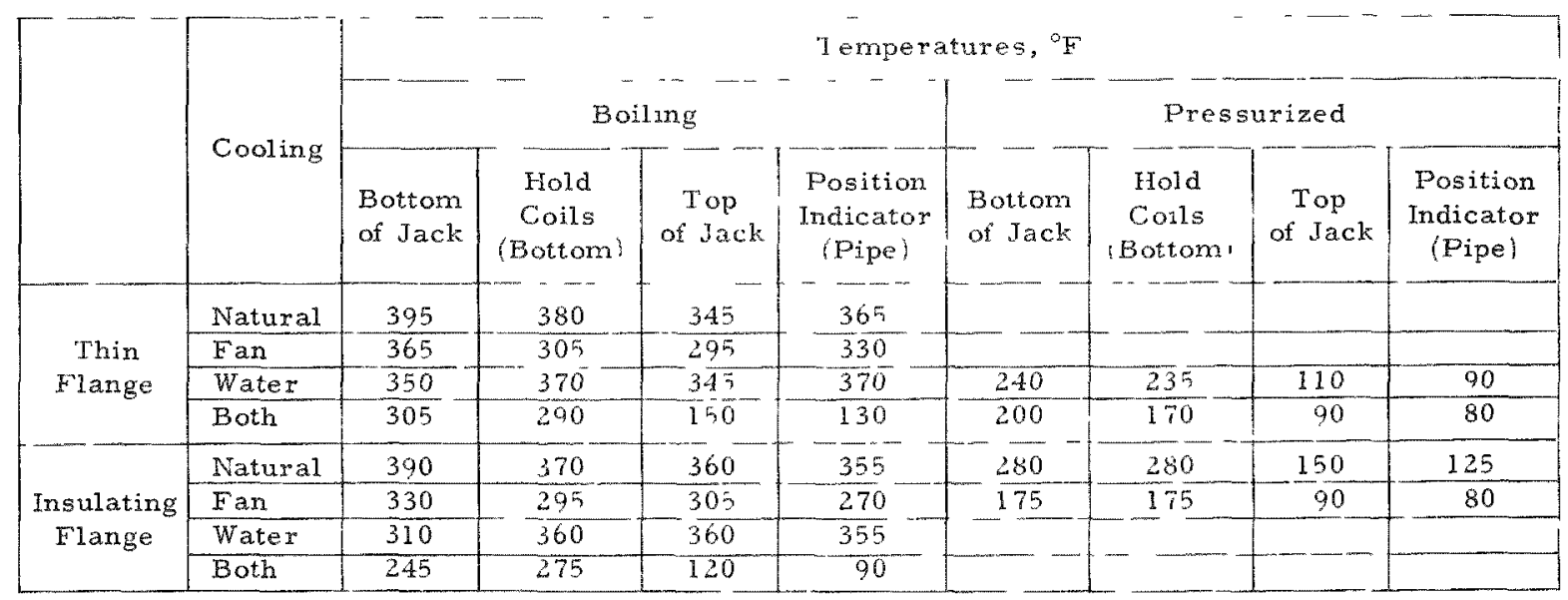

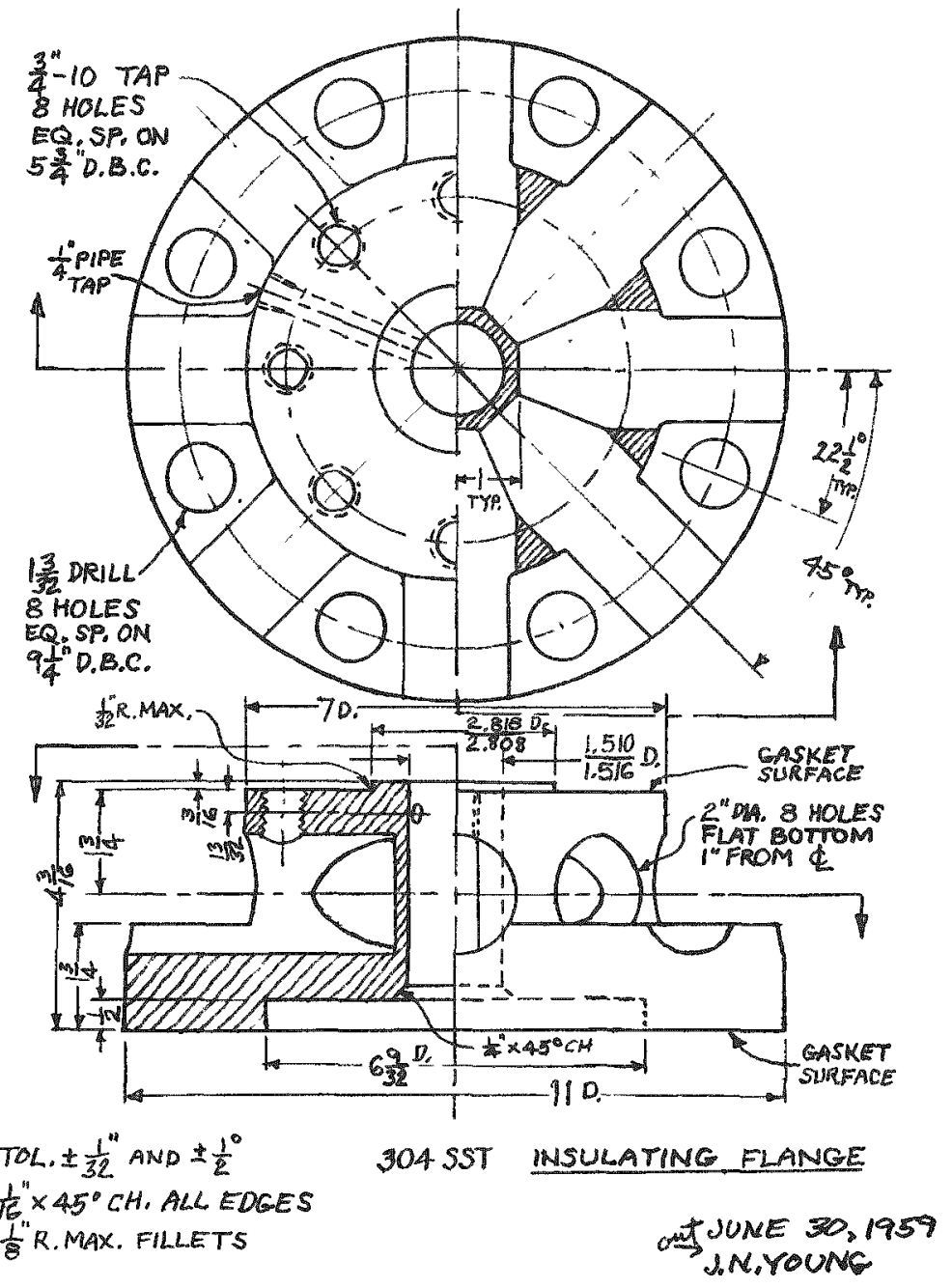




\section{DISCUSSION}

The Grooved Rod Type Magnetic Jack vs the Smooth Rod Type

\section{Size}

Both types would be of the same diameter since the load capacity is limited by the diameter of the lift magnet. Although the grooved rod could be a little smaller than the smooth rod cluster, this would make very little difference in the outside diameter of the jack. The smooth rod type is about twice as long as the grooved rod type and, if the gripping strength must be stronger than the lifting strength, the difference is somewhat greater.

Cost

The cost of the grooved rod type is probably a little more since it has two precision gripper mechanisms that must not wear and a long rod with many grooves, while the coils and the pressure shell are less costly.

\section{Position Indication}

The grooved rod type has the adrantage in this respect since the precise position may be obtained by counting steps, assuming that it does not miss a step.

\section{Movement}

The grooved rod type gives a precise step length while the smooth rod type step length is about $3 \%$ larger in the down direction than in the up direction and varies about $2 \%$ from other causes. The smooth rod has the advantage of being able to go down in large steps by the drop and catch method and being able to go up or down with an extra fine step of about 0.006 in., as well as the standard step.

\section{Slippage}

The grooved rod type will not slip under any conditions; however, overloading will cause serious damage. This is not likely in a stationary application except if the rod is gripped while it is dropping. The smooth rod type will slip only if the load capacity is exceeded and this does no damage. 


\section{Life}

In the grooved rod type wear is slight because the gripper parts do not carry a load when they are moving, but the allowable wear is quite low. The smooth rod type has a longer life since a great deal of wear may be tolerated.

\section{Reliability}

The smooth rod type has only one moving part and is not affected by dirt, corrosion and wear. The grooved rod type is not recommended for a below the reactor application where dirt is likely to be present.

MAGNETIC JACK COMPARISON CHART

\begin{tabular}{|c|c|c|c|c|c|}
\hline & \multirow{2}{*}{$\begin{array}{c}\text { Impor- } \\
\text { tance } \\
\text { Factor, } \\
\text { A }\end{array}$} & \multicolumn{2}{|c|}{$\begin{array}{l}\text { Grooved } \\
\text { Rod Type }\end{array}$} & \multicolumn{2}{|c|}{$\begin{array}{l}\text { Smooth } \\
\text { Rod Type }\end{array}$} \\
\hline & & $\begin{array}{c}\text { Rating } \\
\text { Factor, } \\
\text { B }\end{array}$ & $\begin{array}{c}\text { Score, } \\
A \times B\end{array}$ & $\begin{array}{c}\text { Rating } \\
\text { Factor, } \\
\text { B }\end{array}$ & $\begin{array}{l}\text { Score } \\
A \times B\end{array}$ \\
\hline Small diameter & 2 & 2 & 4 & 2 & 4 \\
\hline Short length & 2 & 4 & 8 & 2 & 4 \\
\hline Low cost & 2 & 3 & 6 & 4 & 8 \\
\hline Good position indication & 3 & 4 & 12 & 0 & 0 \\
\hline Precise step length & 1 & 4 & 4 & 0 & 0 \\
\hline More than one step length & 1 & 0 & 0 & 4 & 4 \\
\hline No slippage & 3 & 4 & 12 & 0 & 0 \\
\hline No damage from overload & 4 & 0 & 0 & 4 & 16 \\
\hline Wear resistance & 4 & 2 & 8 & 4 & 16 \\
\hline Dirt resistance & 3 & 0 & 0 & 4 & 12 \\
\hline Corrosion resistance & 3 & 2 & 6 & 4 & 12 \\
\hline & & & 60 & & 76 \\
\hline
\end{tabular}




\section{Thick vs Thin Pressure Shells for a Magnetic Jack}

The idea of using a thin pressure shell for a magnetic jack is a carryover from the canned rotor motors the only real advantage being that it avoids the use of nonmagnetic sections, which require quite a few welds. The welding problem has been minimized by a new weld material (see Appendix E) and by the fact that a thick pressure shell has low stresses due to pressure.

Actually, a thick pressure shell is an adrantage for the magnetic jack if it is provided with magnetic and nonmagnetic sections along its length. These magnetic sections. if they are thick enough, spread out the magnetic flux which is transmitted from the shell to the armature. It is important to spread out this magretic flux since the radial forces on the armature are thereby reduced.

Another way of reducing the unbalanced radial force is by reducing the radial clearance of the armature, but this makes the device more sensitive to wear, dirt, corrosion and manufacturing errors. Use of a moderately thick pressure shell does not increase the overall diameter of the jack since spreading out the flux reduces the ampere turns required to transmit the flux, thus reducing the size of the coil.

\section{Cooling vs High-temperature Operation}

There is no cooling problem in the case of a control rod drive 10cated below the reactor ressel since there is no heat transfer by convection, and the heat brought down by conduction is remored by the surrounding air in less than a foot of thimble length The heat produced by the magnet coils is also removed simply by the surroundirg air with a temperature rise of $135^{\circ} \mathrm{F}$ for the hold coils (\#29).

In the case of a drive loc ated abore a boiling reactor, special provisions are necessary in order to keep the drive cooler than the reactor. This may be done with a device for reducing the heat transfer by conduction and convection, with about 0.1 gpm of cooling water and with some fan cooling (see page 18). The cooling water is fed in just below the drive, thus it does not interfere with the remoral of the colls. Cooling of a drive on a pressurized reactor is less of a problem.

The system is simplified if no special cooling is required and there is less danger failure if the drive does not depend on a flow of cooling water and a fan.

On the other hand, coils that are designed to operate at high temperatures are expensive and they must be larger because their resistance is higher at high temperatures. 
In any case, the surrounding air must be cool enough to remove the electrical heat or the coils will become even hotter than the reactor.

Future Development

Although Argonne is not expecting to continue development work on the magnetic jack, there are several parts of the system that could be developed further. These are listed below:

1. mild steel or Armco iron magnet parts with Neo-chrome plating or other protective coating:

2. conforming-type drive rods with re-entry flux path using long coils such as those used on jack \#29:

3. conforming-type drive rods made from extruded-to-size stainless steel:

4. better coil-sequencing switch;

5. metal mounting brackets on the position-indicator coils:

6. digital position indicator.

\section{High-speed Operation}

Using the simple circuit, switching and magnets shown in this report, three inches per minute is about as fast as the jack will lift a rod. This is adequate for most applications, especially if more than one rod is moved at a time. Other laboratories have obtained substantially higher speeds. Atomics International mentions 14 inches per minute with a 300 -pound load and 25 inches per minute with a 50-pound load in their report NAA-SR-3350, page IV-6.

The magnet action limits the speed more than the mechanical action. This is indicated by the results of speed calculations which consider only the inertia effects on the moving parts. The maximum theoretical speed for liftung a 200-pound rod assembly is 285 inches per minute, assuming a 30-pound armature, a 600-pound grip and lift force, and a 0.1 -inch step length 


\section{APPENDIX A}

\section{CALCULATIONS}

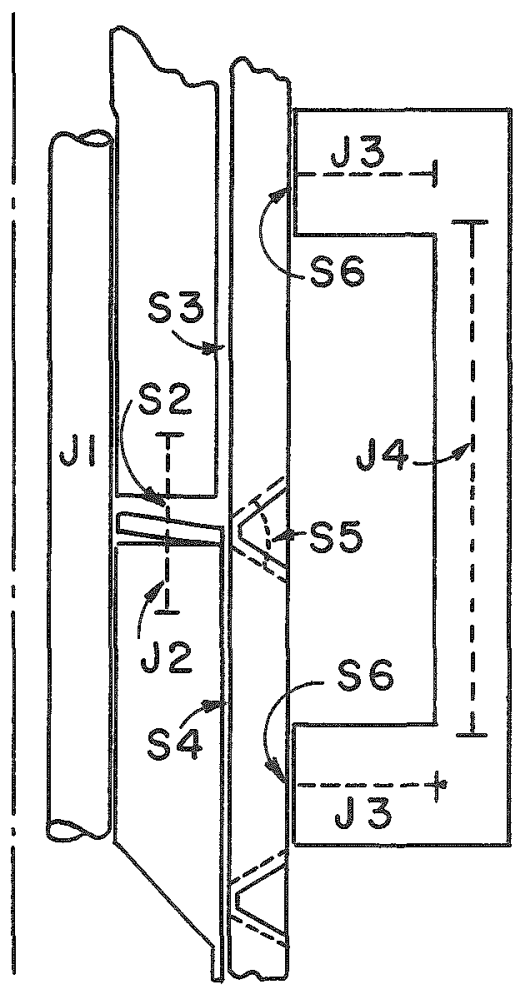

$M=$ Material

$B=$ Flux density, kilolines per in. ${ }^{2}$

$H=$ Field intensity, amp turns per in.

$E$ = Magnetomotive force, amp turns

$I=F l u x$, kilolines

$A=$ Area, in. ${ }^{2}$

$L=$ Length, in.

Subscript "J" is used for magnetic material

Subscript "S" is used for air gaps or other nonmagnetic material

MAGNET CALCULATIONS

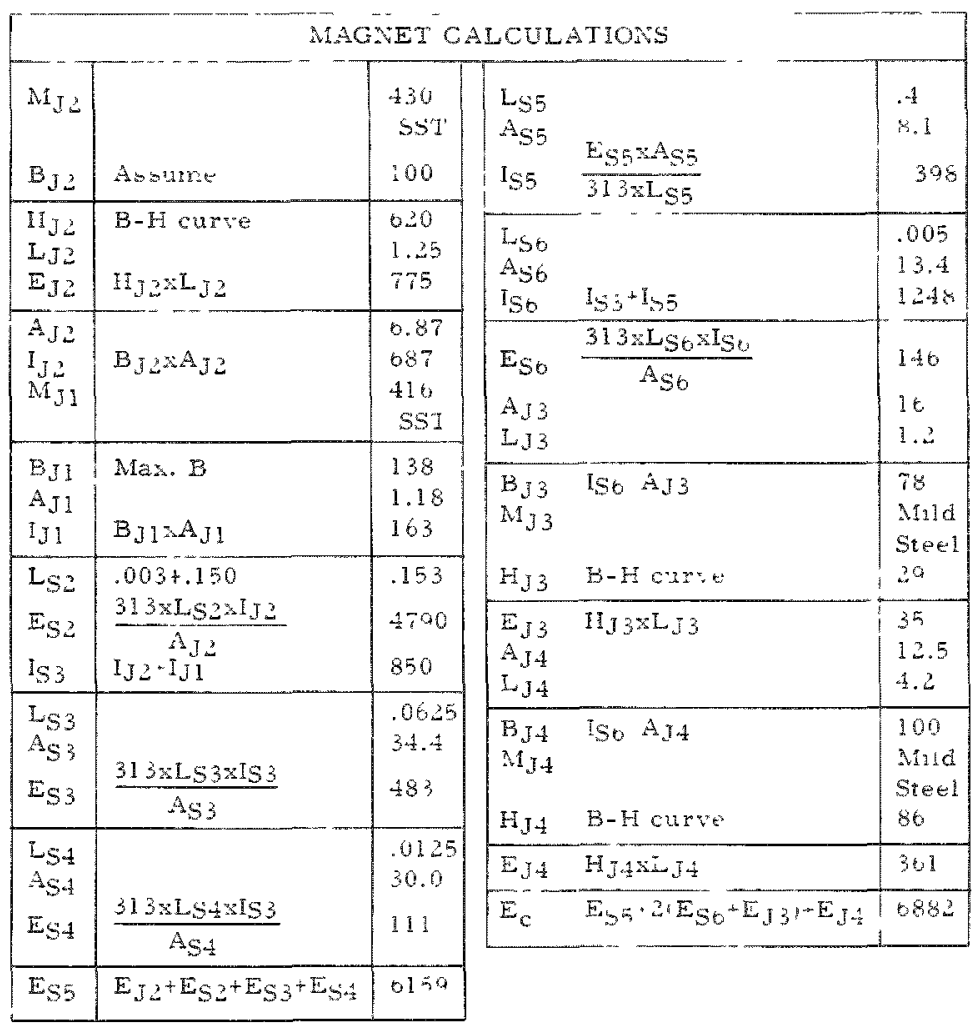

\begin{tabular}{|c|c|c|c|}
\hline \multicolumn{4}{|c|}{ COLL POWER } \\
\hline$n$ & \multirow{5}{*}{$\begin{array}{l}F_{c} n \\
\text { temp. } \\
r \in S . \\
3 \approx r\end{array}$} & turns & 1200 \\
\hline 3 & & amps & 5.33 \\
\hline & & & 180 \\
\hline$r$ & & ohrs & 18.8 \\
\hline$e$ & & $\because$ olts & 100 \\
\hline & $2 x_{3}$ & watts & 533 \\
\hline \multicolumn{4}{|c|}{ PULL CAPACITY } \\
\hline \multirow{2}{*}{$\mathrm{I}$} & \multirow{2}{*}{\multicolumn{2}{|c|}{ 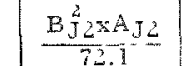 }} & 954 \\
\hline & & & lbs. \\
\hline
\end{tabular}

MOVE MAGNET

Jack \#29H 


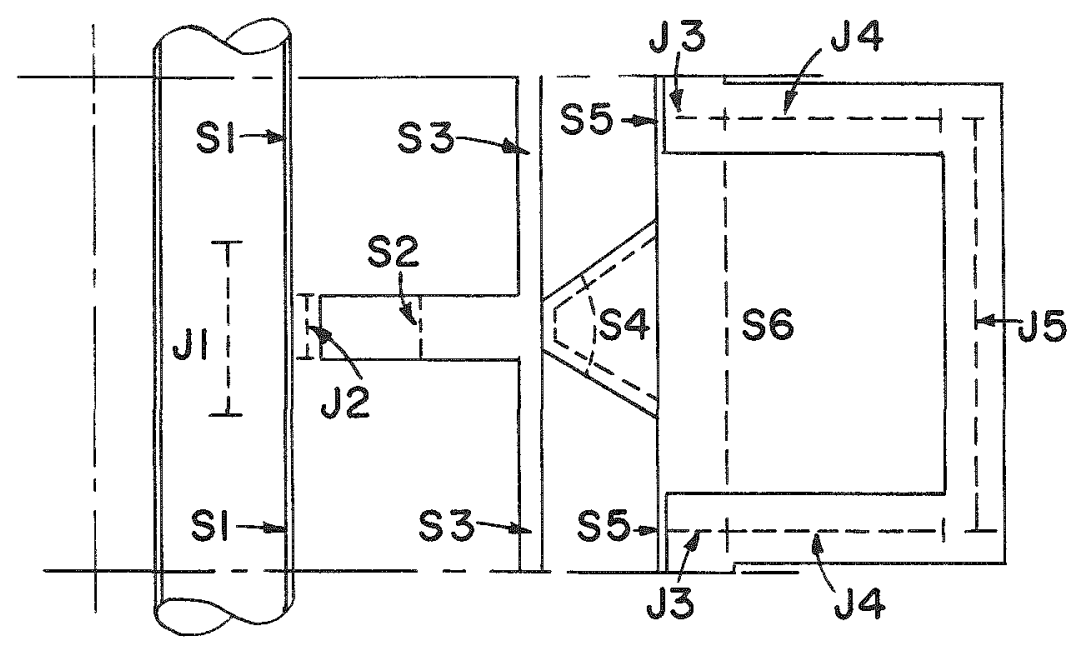

\begin{tabular}{|c|c|c|}
\hline \multicolumn{3}{|c|}{ MAGNET CA } \\
\hline $\begin{array}{l}\mathrm{M}_{\mathrm{J} 1} \\
\mathrm{~B}_{\mathrm{J} 1} \\
\mathrm{H}_{\mathrm{J} 1}\end{array}$ & $\begin{array}{l}\text { Assume } \\
\text { B-H curve }\end{array}$ & $\begin{array}{l}416 \text { SST } \\
100 \\
320\end{array}$ \\
\hline $\begin{array}{l}L_{J 1} \\
E_{J 1} \\
A_{J 1}\end{array}$ & $\mathrm{H}_{\mathrm{J} 1} \times L_{\mathrm{J} 1}$ & $\begin{array}{l}.688 \\
220 \\
1.18\end{array}$ \\
\hline $\begin{array}{l}\mathrm{I}_{\mathrm{J} 1} \\
\mathrm{~L}_{\mathrm{S} 1} \\
\mathrm{~A}_{\mathrm{S} 1}\end{array}$ & $\begin{array}{l}B_{J 1} \times A_{J 1} \\
.002+.00375 \\
A_{J 1} \times 2.5\end{array}$ & $\begin{array}{l}118 \\
.00575 \\
2.95\end{array}$ \\
\hline $\begin{array}{l}I_{S 1} \\
E_{S 1} \\
M_{J 2}\end{array}$ & $\frac{{ }_{31}^{I_{I}} 3 \times L_{S 1} \times I_{S 1}}{A_{S I}}$ & $\begin{array}{l}118 \\
72.0 \\
430 \mathrm{SST}\end{array}$ \\
\hline $\begin{array}{l}\mathrm{B}_{\mathrm{J} 2} \\
\mathrm{~A}_{\mathrm{J} 2} \\
\mathrm{IJ}_{2}\end{array}$ & $\begin{array}{l}\text { Max. B } \\
B_{\mathrm{J} 2} \times A_{J 2}\end{array}$ & $\begin{array}{l}138 \\
.488 \\
67.3\end{array}$ \\
\hline $\begin{array}{l}E_{S 2} \\
A_{S 2} \\
L_{S 2}\end{array}$ & $E_{J 1}+2 E_{S 1}$ & $\begin{array}{l}364 \\
6.54 \\
.25 \\
\end{array}$ \\
\hline $\begin{array}{l}\mathrm{I}_{\mathrm{S} 2} \\
\mathrm{IS} 3 \\
\mathrm{~L}_{\mathrm{S} 3}\end{array}$ & $\begin{array}{l}\frac{E_{\mathrm{S} 2} \times A_{S 2}}{313 \times I_{S 2}} \\
I_{J 1}+I_{J} 2+I_{S 2}\end{array}$ & $\begin{array}{l}30.4 \\
\\
215.7 \\
.0625\end{array}$ \\
\hline $\begin{array}{l}A_{S 3} \\
E_{S 3} \\
E_{S 4}\end{array}$ & $\frac{313 \times I_{S 3} \times I_{S 3}}{A_{S 3}}$ & $\begin{array}{l}9.29 \\
454 \\
1272\end{array}$ \\
\hline 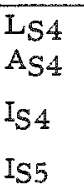 & $\begin{array}{l}\frac{E_{S 4 \times A} \times A_{S 4}}{313 \times .4} \\
I_{S 3+I S 4}+I_{S 4}\end{array}$ & $\begin{array}{l}.4 \\
8.1 \\
82 \\
298\end{array}$ \\
\hline
\end{tabular}

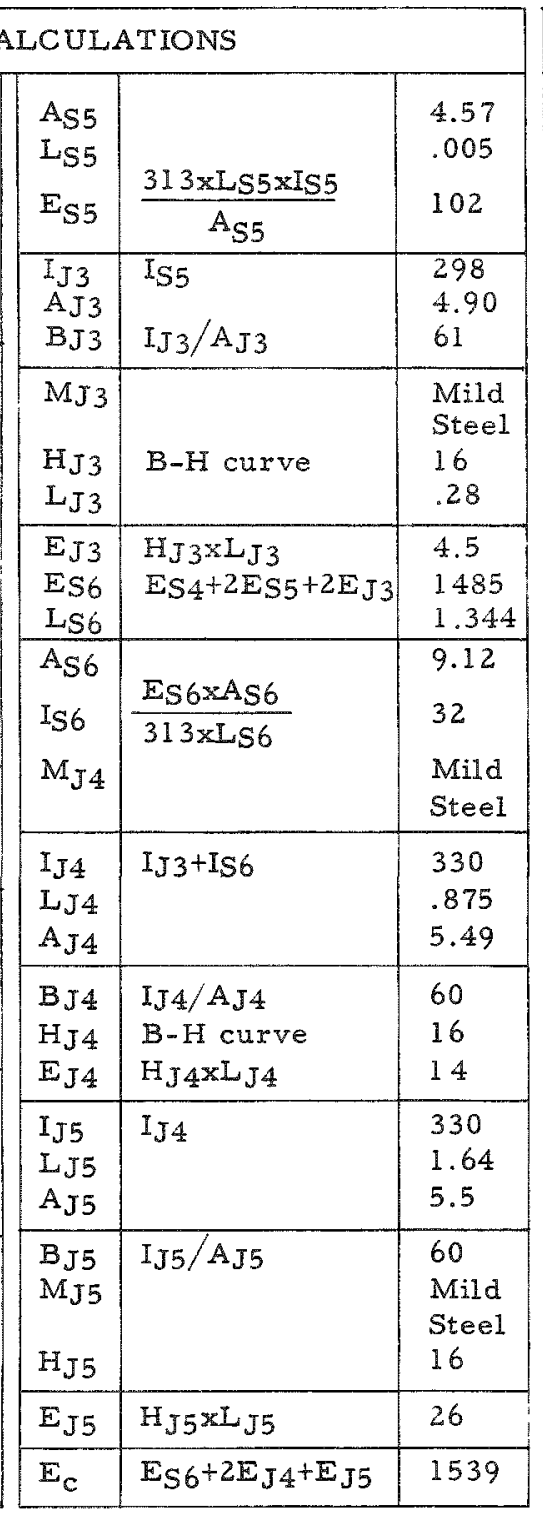

\begin{tabular}{|l|ll|l|}
\hline \multicolumn{4}{|c|}{ COIL POWER } \\
\hline $\mathrm{n}$ & & Turns & 430 \\
$\mathrm{i}$ & $\mathrm{E}_{\mathrm{c}} / \mathrm{n}$ & amps & 3.58 \\
& Temp. & ${ }^{\circ} \mathrm{C}$ & 180 \\
$\mathrm{r}$ & Res. & ohms & 6.28 \\
$\mathrm{e}$ & $\mathrm{i} \times \mathrm{r}$ & volts & 22.5 \\
\hline & $\mathrm{e} \times \mathrm{i} \times 8$ & watts & \\
& & (8 coils) & 644 \\
\hline
\end{tabular}

\begin{tabular}{|l|l|l|}
\hline \multicolumn{3}{|c|}{ GRIP CAPACITY } \\
\hline $\mathrm{B}_{\mathrm{S} 1}$ & I $_{\mathrm{S} 1} / \mathrm{A}_{\mathrm{S} 1}$ & 40.0 \\
$\mathrm{~N}$ & Mag. circuits & 8 \\
$\mathrm{f}$ & $\begin{array}{l}\text { Coefficient } \\
\text { of Friction }\end{array}$ & .45 \\
\hline$F$ & $\frac{\mathrm{B}_{\mathrm{S} 1}^{2} \mathrm{~A}_{\mathrm{SI}} \mathrm{N}}{36.05}$ & $\begin{array}{l}470 \\
\text { lbs. }\end{array}$ \\
\hline
\end{tabular}

GRIP MAGNET

Jack \# $29 \mathrm{H}$ 


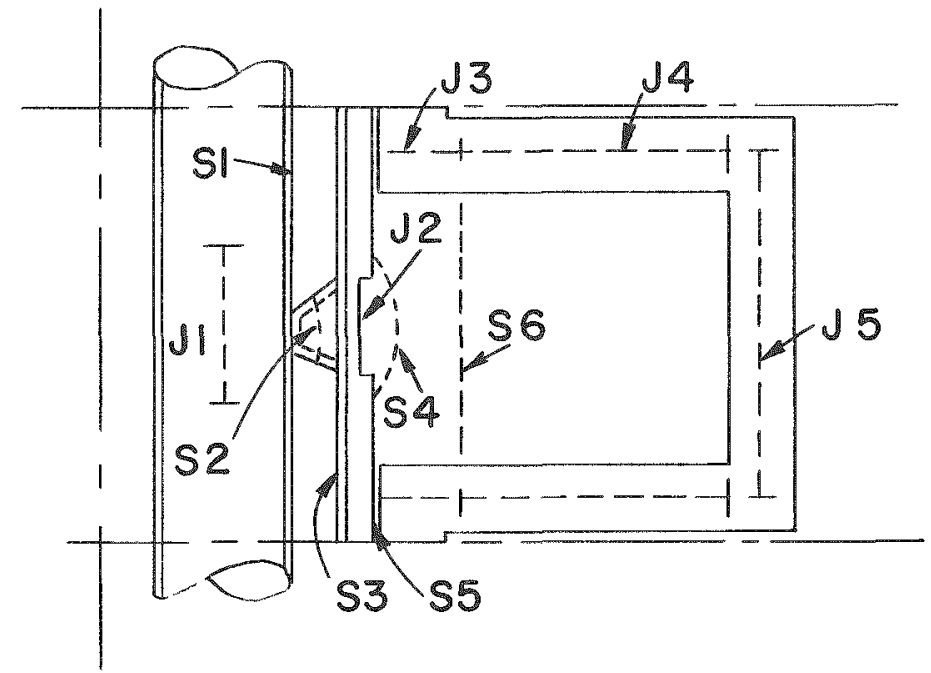

\begin{tabular}{|c|c|c|}
\hline \multicolumn{3}{|c|}{ MAGNET CA } \\
\hline $\begin{array}{l}\mathrm{M}_{\mathrm{J} 1} \\
\mathrm{~B}_{\mathrm{J} 1} \\
\mathrm{H}_{\mathrm{JI}}\end{array}$ & $\begin{array}{l}\text { Assume } \\
\text { B-H curve }\end{array}$ & $\begin{array}{l}416 \mathrm{SST} \\
100 \\
320\end{array}$ \\
\hline $\begin{array}{l}\mathrm{L}_{\mathrm{J} 1} \\
\mathrm{E}_{\mathrm{J} 1} \\
\mathrm{~A}_{\mathrm{J} 1}\end{array}$ & $\mathrm{H}_{\mathrm{J} 1} \times \mathrm{LJ} 1$ & $\begin{array}{l}.625 \\
200 \\
1.18\end{array}$ \\
\hline $\begin{array}{l}I_{J 1} \\
I_{S 1} \\
A_{S 1}\end{array}$ & $\begin{array}{l}\mathrm{B}_{\mathrm{J} 1} \times \mathrm{A}_{\mathrm{J} 1} \\
.002+.00375 \\
\mathrm{~A}_{\mathrm{J} 1} \times 2.5\end{array}$ & $\begin{array}{l}118 \\
.00575 \\
2.95\end{array}$ \\
\hline $\begin{array}{l}E_{S 1} \\
E_{S 2} \\
A_{S 2} \\
\end{array}$ & $\begin{array}{l}\frac{313 \times L_{S 1} \times I J 1}{A_{S 1}} \\
E_{J 1}+2 \times E_{S 1}\end{array}$ & $\begin{array}{l}72.0 \\
344 \\
1.13 \\
\end{array}$ \\
\hline $\begin{array}{l}\mathrm{L}_{\mathrm{S} 2} \\
\mathrm{I}_{\mathrm{S} 2} \\
\mathrm{I}_{\mathrm{S} 3}\end{array}$ & $\begin{array}{l}\frac{E_{S 2 \times} \times A_{S 2}}{313 \times L_{S 2}} \\
I_{J_{1} 1}+I_{S 2}\end{array}$ & $\begin{array}{l}.25 \\
5.0 \\
123 \\
\end{array}$ \\
\hline $\begin{array}{l}A_{S 3} \\
L_{S 3} \\
E_{S 3}\end{array}$ & $\frac{313 \times L_{S 3 \times I S 3}}{A_{S 3}}$ & $\begin{array}{l}4.22 \\
.0075 \\
68\end{array}$ \\
\hline $\begin{array}{l}\mathrm{M}_{\mathrm{J} 2} \\
\mathrm{~B}_{\mathrm{J} 2} \\
\mathrm{~A}_{\mathrm{J} 2}\end{array}$ & Max. B & $\begin{array}{l}\text { Mild } \\
\text { Steel } \\
138 \\
.29\end{array}$ \\
\hline $\begin{array}{l}I_{\mathrm{J} 2} \\
\mathrm{E}_{\mathrm{S} 4} \\
\mathrm{~L}_{\mathrm{S} 4} \\
\end{array}$ & $\begin{array}{l}\mathrm{B}_{\mathrm{J} 2} \times \mathrm{A}_{\mathrm{J} 2} \\
\mathrm{E}_{\mathrm{S} 2}+2 \mathrm{E}_{\mathrm{S} 3}\end{array}$ & $\begin{array}{l}40 \\
480 \\
.6 \\
\end{array}$ \\
\hline $\begin{array}{l}\mathrm{A}_{\mathrm{S} 4} \\
\mathrm{I}_{\mathrm{S} 4}\end{array}$ & $\frac{E_{S 4 \times A_{S 4}}}{313 \times L_{S 4}}$ & $\begin{array}{l}2.5 \\
6.4\end{array}$ \\
\hline
\end{tabular}

\begin{tabular}{|c|c|c|}
\hline \multicolumn{3}{|c|}{ CULATIONS } \\
\hline $\begin{array}{l}\text { IS5 }_{\text {S }} \\
\text { A S5 }_{\text {L }} \\
\text { LS5 }_{\text {S }}\end{array}$ & $\mathrm{I}_{\mathrm{S} 3}+\mathrm{I}_{\mathrm{J} 2}+\mathrm{I}_{\mathrm{S} 4}$ & $\begin{array}{l}169 \\
2.3 \\
.005\end{array}$ \\
\hline $\begin{array}{l}E_{\mathrm{S} 5} \\
A_{\mathrm{J} 3} \\
B_{\mathrm{J} 3}\end{array}$ & $\begin{array}{l}\frac{313 \times L_{S 5} \times I_{S 5}}{A_{S 5}} \\
\text { IS5 }_{A_{J} 3}\end{array}$ & $\begin{array}{l}115 \\
2.6 \\
65\end{array}$ \\
\hline $\begin{array}{l}\mathrm{M}_{\mathrm{J} 3} \\
\mathrm{H}_{\mathrm{J} 3} \\
\mathrm{~L}_{\mathrm{J} 3}\end{array}$ & B-H curve & $\begin{array}{l}\text { Mild } \\
\text { Steel } \\
19 \\
.37 \\
\end{array}$ \\
\hline $\begin{array}{l}\mathrm{E}_{\mathrm{J} 3} \\
\mathrm{E}_{\mathrm{S} 6} \\
\mathrm{~L}_{\mathrm{S} 6}\end{array}$ & $\begin{array}{l}\mathrm{H}_{\mathrm{J} 3} \times \mathrm{L}_{\mathrm{J} 3} \\
\mathrm{E}_{\mathrm{S} 4+2\left(\mathrm{E}_{\mathrm{S} 5}+\mathrm{E}_{\mathrm{J} 3}\right)}\end{array}$ & \begin{tabular}{|l|}
7 \\
724 \\
1.094
\end{tabular} \\
\hline $\begin{array}{l}{ }_{\mathrm{S} 6} \\
\mathrm{I}_{\mathrm{S} 6} \\
\mathrm{M}_{\mathrm{J} 4}\end{array}$ & $\frac{E_{S 6 \times A_{S 6}}}{313 \times L_{S 6}}$ & $\begin{array}{l}7.07 \\
15.0 \\
\text { Mild } \\
\text { Steel }\end{array}$ \\
\hline $\begin{array}{l}\mathrm{I}_{\mathrm{J} 4} \\
\mathrm{~L}_{\mathrm{J} 4} \\
\mathrm{~A}_{\mathrm{J} 4}\end{array}$ & $\mathrm{I}_{\mathrm{S} 5}+\mathrm{I}_{\mathrm{S} 6}$ & $\begin{array}{l}184 \\
1.10 \\
3.5 \\
\end{array}$ \\
\hline $\begin{array}{l}B_{\mathrm{J} 4} \\
\mathrm{H}_{\mathrm{J} 4} \\
\mathrm{E}_{\mathrm{J} 4}\end{array}$ & $\begin{array}{l}\mathrm{I}_{\mathrm{J} 4} / \mathrm{A}_{\mathrm{J} 4} \\
\mathrm{~B}_{-\mathrm{H}} \text { curve } \\
\mathrm{H}_{\mathrm{J} 4} 4 \mathrm{LL}_{\mathrm{J} 4}\end{array}$ & \begin{tabular}{|l|}
53 \\
12.3 \\
13.5
\end{tabular} \\
\hline $\begin{array}{l}\text { MJ5 } \\
\text { LJ5 } \\
\text { AJ5 }\end{array}$ & & \begin{tabular}{|l|} 
Mild \\
Steel \\
1.39 \\
4.0 \\
\end{tabular} \\
\hline $\begin{array}{l}\mathrm{B}_{\mathrm{J} 5} \\
\mathrm{H}_{\mathrm{J} 5} \\
\mathrm{E}_{J 5}\end{array}$ & $\begin{array}{l}\mathrm{IJ}_{\mathrm{J} 4} / \mathrm{AJ}_{\mathrm{J} 5} \\
\mathrm{~B}-\mathrm{H} \text { curve } \\
\mathrm{H}_{\mathrm{J} 5} \mathrm{xL}_{\mathrm{J} 5}\end{array}$ & $\begin{array}{l}46 \\
10 \\
14\end{array}$ \\
\hline$E_{c}$ & $E_{S 6}+2 E_{J 4}+E_{J 5}$ & 765 \\
\hline
\end{tabular}

\begin{tabular}{|c|c|c|c|c|}
\hline \multicolumn{5}{|c|}{ COIL POWER } \\
\hline $\begin{array}{l}r \\
e\end{array}$ & \multicolumn{2}{|c|}{$\begin{array}{l}E_{c}, n \\
\text { temp. } \\
\text { res. } \\
i x r\end{array}$} & $\begin{array}{l}\text { Turns } \\
\text { amps } \\
{ }^{\circ} \mathrm{C} \\
\text { ohms } \\
\text { volts }\end{array}$ & $\begin{array}{l}600 \\
1.28 \\
180 \\
9.18 \\
11.75\end{array}$ \\
\hline & \multicolumn{2}{|c|}{ exix 8} & $\begin{array}{l}\text { watts } \\
(8 \text { coils })\end{array}$ & 120 \\
\hline \multicolumn{5}{|c|}{ HOLD CAPACITY } \\
\hline \multicolumn{2}{|c|}{$\begin{array}{l}\mathrm{B}_{\mathrm{S} 1} \\
\mathrm{~N}\end{array}$} & \multicolumn{2}{|c|}{$\begin{array}{l}I_{\mathrm{J} 1} / \mathrm{A}_{\mathrm{S} 1} \\
\text { Mag. } \\
\text { circuits } \\
\text { Coefficient } \\
\text { of Friction }\end{array}$} & $\begin{array}{l}40.0 \\
8\end{array}$ \\
\hline \multicolumn{2}{|l|}{$F$} & \multicolumn{2}{|c|}{$\frac{\mathrm{BS}_{\mathrm{S} 1 \mathrm{ASI}}^{2} \mathrm{Nf}}{36.05}$} & $\begin{array}{l}470 \\
1 \mathrm{bs} .\end{array}$ \\
\hline
\end{tabular}

HOLD MAGNET Jack \#29L 


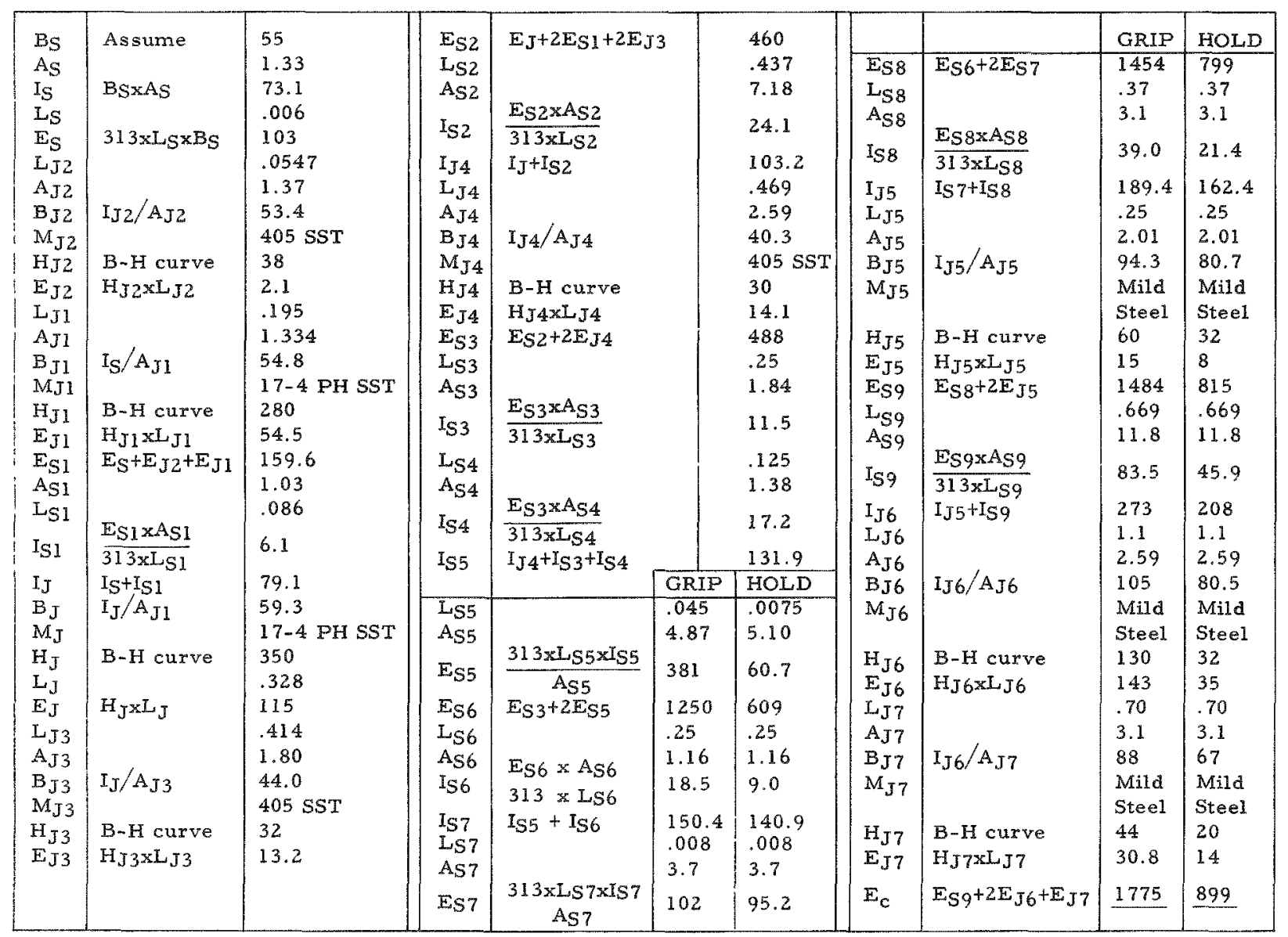

GRIP AND HOLD MAGNETIC CALCULATIONS

Jack \#27 


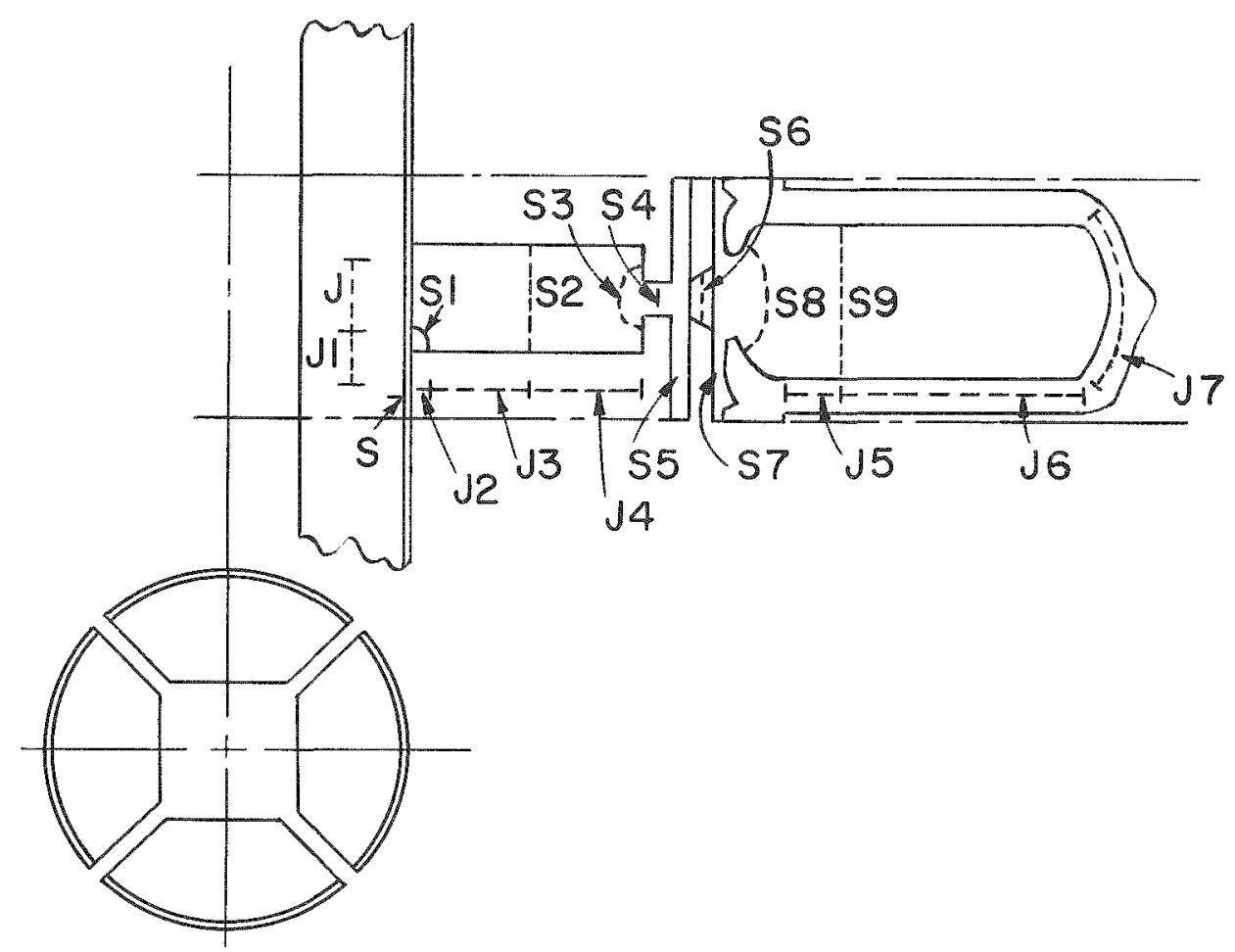

COIL POWER

\begin{tabular}{|c|l|l|l|l|}
\hline & & & GRIP & HOLD \\
\cline { 3 - 5 } $\mathrm{n}$ & & Turns & 300 & 300 \\
& $\mathrm{E}_{\mathrm{c}} / \mathrm{n}$ & amps & 5.91 & 3.00 \\
$\mathrm{Temp}$ & ${ }^{\circ} \mathrm{C}$ & 180 & 180 \\
$\mathrm{r}$ & Res. & ohms & 4.73 & 4.73 \\
$\mathrm{e}$ & $\mathrm{i} \times \mathrm{r}$ & volts & 28.0 & 14.2 \\
& $\mathrm{e} \times \mathrm{i} \times 8$ & watts & & \\
& & (8 coils) & $\underline{1330}$ & $\underline{340}$ \\
\hline
\end{tabular}

GRIP OR HOLD

CAPACITY

\begin{tabular}{|c|l|l|}
\hline $\mathrm{N}$ & Mag. circuits & 8 \\
$\mathrm{f}$ & $\begin{array}{l}\text { Coefficient } \\
\text { of Friction }\end{array}$ & .45 \\
$\mathrm{~F}$ & $\frac{\mathrm{B}_{\mathrm{S}}^{2} \mathrm{xA} \times \mathrm{A}_{\mathrm{S} X \mathrm{Nxf}}}{36.05}$ & $\underline{401}$ \\
\hline
\end{tabular}


Water Dash Pot Design

One of the functions of a control rod in a nuclear reactor is to shut the reactor off quickly in case of an emergency. This is done by a fast insertion of the control rod into the reactor core, usually by gravity. A dash pot is one means of stopping the rod at the end of its travel. The design of such a dash pot is the subject of this paper.

The dash pot piston is a part of the control rod assembly and the dash pot cylinder is stationary. A self-contained dash pot using a return spring is not used because of the possibility of the rod operating while the dash pot is stuck closed.

The piston, as it travels down through the pipe before entering the dash pot cylinder, limits the speed of insertion without delaying the initial movement of the rod to any measurable extent.

The clearance between the piston and the cylinder is used as the orifice and is made to decrease toward the end of the travel by tapering the piston or the cylinder or both. A taper with a certain contour will provide a constant deceleration. This would give the ideal action; however, a straight taper is more economical and is sufficient for most applications. The clearance at the beginning of the travel is calculated to give an initial force equal to the average force. This gives the smallest peak force, which occurs near the center of the travel, and is equal to 1.3 times the average force.

The minimum clearance (at the end of the travel) is a compromise between a clearance that is large enough to prevent trouble from dirt and corrosion and a clearance that is small enough to slow the rod down to a point where the final impact is small. This compromise is no problem if the diameter of the piston is large enough. To minimize the final velocity for a given minimum clearance, the last $10 \%$ of length is not tapered.

The following example of calculations is similar to that used to calculate the internal dash pot that has been in operation on EBWR with the linear seal drive.

The following method is a convenient way of calculating fluid flow The orifice formula was derived from the general law of flow: $V=(2 \mathrm{gh})^{1 / 2}$. The leakage formula was derived from the stuffing box leakage formula given in Marks' Mechanical Engineers' Handbook. 
Flow through annular clearances

orifice formula for large clearances:

$$
\begin{aligned}
& Q=0.0873 \mathrm{KCD}(\mathrm{P} / \mathrm{B})^{1 / 2} \text { for any fluid } \\
& Q=0.4 \mathrm{CDP} \mathrm{P}^{1 / 2} \text { for } 100^{\circ} \mathrm{F} \text { water and } \mathrm{K}=0.87
\end{aligned}
$$

leakage formula for small clearances:

$$
\begin{aligned}
& Q=0.0018 \mathrm{C}^{3} \mathrm{DP} / \mathrm{M} \mathrm{L} \text { for any fluid } \\
& Q=0.00265 \mathrm{C}^{3} \mathrm{DP} / \mathrm{L} \text { for } 100^{\circ} \mathrm{F} \text { water }
\end{aligned}
$$

Use the formula which gives the smaller $Q$.

$Q=$ flow in cubic inches per second

$\mathrm{C}=$ radial clearance in mils (inch/1000)

$\mathrm{D}=$ mean diameter of clearance in inches

$P=$ pressure in pounds per square inch

$\mathrm{L}=$ length of clearance in inches

$\mathrm{M}=$ absolute viscosity of fluid in centipoises

$B=$ density of fluid in pounds per cubic inch

$K=$ discharge coefficient

For this example the following parameters are assumed:

$\begin{array}{rlr}\mathrm{W} \text { weight in air, } \mathrm{lb} & =234 \\ \mathrm{~W}_{1} \text { buoyancy (half submerged), } \mathrm{lb} & =14 \\ \mathrm{~W}_{2} \text { friction (estimated), } 1 \mathrm{~b} & =10 \\ \mathrm{~F}_{1} \text { load, } 1 \mathrm{~b}=\mathrm{W}-\mathrm{W}_{1}-\mathrm{W}_{2}=234-14-10 & =210 \\ \mathrm{D} \text { piston diameter, in. } & =3.568 \\ \mathrm{~A} \text { piston area, in. } & =10.0 \\ \mathrm{~S} \text { dash pot length (total), in. } & =2.75 \\ \mathrm{~L}_{1} \text { dash pot length (tapered portion), in. } & =10 \\ \mathrm{C}_{4} \text { final dash pot radial clearance } & \text { (minimum), mils } & =10\end{array}$

If the velocity at which the piston enters the dash pot is governed by the retarding effect of the piston displacing water in a pipe, the energy to be absorbed by the dash pot may be calculated as follows:

$$
\begin{aligned}
& J \text { pipe inside diameter, in. }=3.826 \\
& P_{1} \text { pressure, } \mathrm{psi}=\mathrm{F}_{1} / \mathrm{A}=210 / 10.0=21.0 \\
& \mathrm{C}_{1} \text { radial clearance, } \mathrm{mils}=1000(\mathrm{~J}-\mathrm{D}) \\
& =1000(3.826-3.568) \quad=129 \\
& \mathrm{D}_{1} \text { clearance mean diameter, in. }= \\
& \mathrm{D}+\left(\mathrm{C}_{1} / 1000\right)=3.568+(129 / 1000)=3.697 \\
& \text { water temperature, }{ }^{\circ} \mathrm{F} \quad=100
\end{aligned}
$$


Q flow, in. $3 / \mathrm{sec}=0.4 \mathrm{C}_{1} \mathrm{D}_{1}\left(\mathrm{P}_{1}\right)^{1 / 2}$ $=(0.4)(129)(3.697)(21.0)^{1 / 2}=874.4$

$\mathrm{V}$ piston velocity, in. $/ \mathrm{sec}=\mathrm{Q} / \mathrm{A}=874.4 / 10.0=87.4$

$\mathrm{E}_{1}$ kinetic energy, in. $\mathrm{lb}=\mathrm{W} \mathrm{V} \mathrm{V}^{2} / 2 \mathrm{~g}$ $=(234)(87.42) /(2)(12)(32.2)=2310$

$E_{2}$ potential energy, in. $1 \mathrm{~b}=F_{1} S=(210)(3)=630$

$\mathrm{E}$ total energy, in. $\mathrm{lb}=\mathrm{E}_{1}+\mathrm{E}_{2}=2310+630=2940$

If the rod is not retarded by hydraulic effects, the energy to be absorbed by the dash pot may be calculated as follows:

$S_{1}$ length of rod travel including dash pot, in. (for this example a length is assumed which gives the same energy arrived at by the previous calculation) $=18.75$

$E$ total energy, in。 $=F_{1} S_{1}=(210)(18.75) \quad=2940$

Knowing the energy to be absorbed, the stopping forces may be calculated as follows:

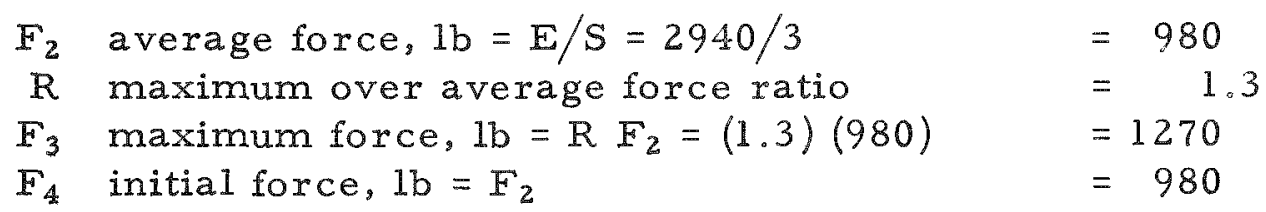

Using the initial force, the initial dash pot clearance is calculated as follows:

$$
\begin{array}{lll}
\mathrm{P}_{2} \text { pressure, psi }=\mathrm{F}_{4} / \mathrm{A}=980 / 10.0 & =98 \\
\mathrm{D}_{2} \text { clearance mean diameter (estimated), in。 } & =3.6 \\
\mathrm{C}_{2} \quad \begin{array}{l}
\text { radial clearance (first try })_{9} \text { mils } \\
=Q / 0.4 \mathrm{D}_{2}\left(\mathrm{P}_{2}\right)^{1 / 2}=874.4 /(0.4)(3.6)(98)^{1 / 2}
\end{array} & =61.3 \\
\mathrm{D}_{3} \quad \begin{array}{l}
\text { clearance mean diameter, in. } \\
\quad=\mathrm{D}+\left(\mathrm{C}_{2} / 1000\right)=3.568+(61.3 / 1000)
\end{array} & =3.629 \\
\mathrm{C}_{3} \quad \begin{array}{l}
\text { initial radial clearance, mils } \\
=Q / 0.4 \mathrm{D}_{3}\left(\mathrm{P}_{2}\right)^{1 / 2}=874.4 /(0.4)(3.629)(98)^{1 / 2}
\end{array} & =60.8
\end{array}
$$

The impact at the end of the dash pot travel is determined by the final radial clearance and by the spring constant of the parts. The energy which must be dissipated by deflection of the mechanical parts is calculated as follows:

$$
\begin{array}{ll}
\mathrm{D}_{4} \quad \begin{array}{l}
\text { clearance mean diameter, in。 }=\mathrm{D}+\left(\mathrm{C}_{4} / 1000\right) \\
=3.568+(10 / 1000)
\end{array} & 3.578 \\
\mathrm{Q}_{2} \quad \text { flow, in. } 3 / \mathrm{sec}(\text { orifice formula }) & =65.5 \\
\quad=0.4 \mathrm{C}_{4} \mathrm{D}_{4}\left(\mathrm{P}_{1}\right)^{1 / 2}=(0.4)(10)(3.578)(21.0)^{1 / 2} & =0.94
\end{array}
$$


$Q_{3}$ flow, in. $3 / \mathrm{sec}$ (leakage formula)

$=0.00265 \mathrm{C}_{\frac{3}{4}} \mathrm{D}_{4} \mathrm{P}_{1} / \mathrm{L}$

$=(0.00265)\left(10^{3}\right)(3.578)(21.0) / 0.94=212$

$Q_{4}$ flow, in. $3 / \mathrm{sec}=$ smaller of $Q_{2}$ and $Q_{3}=65.5$

$\mathrm{V}_{4}$ piston velocity, in. $/ \mathrm{sec}=Q_{4} / \mathrm{A}$

$$
=65.5 / 10.0=6.55
$$

$\mathrm{E}_{4}$ kinetic energy, in. $1 \mathrm{~b}=\mathrm{W} \mathrm{V} \frac{2}{4} / 2 \mathrm{~g}$

$=(234)(6.552) /(2)(12)(32.2)=13.0$

amount of compression of the parts to give a striking force equal to $F_{3}$, in.

$=2 E_{4} / F_{3}=(2)(13.0) / 1270=0.0205$

height from which the rod could be dropped freely to give a striking force equal to the impact at the end of the dash pot travel, in. $=E_{4} / W=13.0 / 234=0.0555$

The following calculations are not necessary for designing the dash pot but may be used if a force curve is desired. The maximum over average force ratio, $R$, is obtained from this curve; however, $R$ is close to 1.3 in most cases. The dash pot length is divided into increments the average force of which is estimated and then checked. The correct force is usually obtained after a few tries. The use of about ten increments gives a close enough approximation; thus the only uncertainty in the se calculations is the discharge coefficient, $K$.

The following example shows the calculating of the second and third points of the curve. The first point was calculated on page 30.

\begin{tabular}{|c|c|c|c|c|c|}
\hline & $\begin{array}{l}\text { try } \\
\text { increment begmining } \\
\text { increment end }\end{array}$ & $\begin{array}{l}1 \text { st } \\
0 \\
025\end{array}$ & $2 \mathrm{nd}$ & $\begin{array}{l}1 \mathrm{st} \\
0.25 \\
050\end{array}$ & 2nd \\
\hline $\begin{array}{l}\mathrm{S} \\
\mathrm{C}_{\mathrm{A}} \\
\mathrm{DA}_{\mathrm{A}}\end{array}$ & $\begin{array}{l}\text { increment length, in. } \\
\text { average radial clearance, muls } \\
\text { average clearance mean diameter, } \mathrm{m} \text {. } \\
\quad=\mathrm{D}+\left(\mathrm{C}_{\mathrm{A}} / 1000\right)=3568+\left(\mathrm{C}_{\mathrm{A}} 1000\right)\end{array}$ & $\begin{array}{l}025 \\
58 \pm \\
3.026\end{array}$ & & $\begin{array}{l}025 \\
538 \\
3622\end{array}$ & \\
\hline $\begin{array}{l}\mathrm{E}_{\mathrm{I}} \\
\mathrm{E}_{\mathrm{G}} \\
\mathrm{E}\end{array}$ & $\begin{array}{l}\text { initial kinetic energy, in } 1 \mathrm{~b} \\
\quad=\left(\mathrm{E}_{\mathrm{F}} \text { from previous column) }\right. \\
\text { energy gamed, } \mathrm{n} . \mathrm{lb}=\mathrm{F}_{1} \mathrm{~S}-210 \mathrm{~S} \\
\text { total energy, } \mathrm{n} . \mathrm{b}=\mathrm{E}_{\mathrm{I}}+\mathrm{E}_{\mathrm{G}}\end{array}$ & $\begin{array}{r}2310 \\
52.5 \\
23625\end{array}$ & & $\begin{array}{r}21075 \\
52.5 \\
2160\end{array}$ & \\
\hline $\begin{array}{l}Q \\
F_{A} \\
E_{L}\end{array}$ & $\begin{array}{l}\text { intial flow, } \mathrm{m}^{3} / \mathrm{sec}=\left(Q_{\mathrm{F}} \text { from }\right. \\
\text { previous column }) \\
\text { estimated average force, } 1 \mathrm{~b} \\
\text { energy lost, in } \mathrm{lb}=\mathrm{FAS}\end{array}$ & $\begin{array}{l}874.4 \\
1000 \\
250\end{array}$ & $\begin{array}{r}1020 \\
255\end{array}$ & $\begin{array}{l}834 \\
1070 \\
267.5\end{array}$ & $\begin{array}{r}1085 \\
271\end{array}$ \\
\hline $\begin{array}{l}E_{F} \\
V_{F} \\
Q_{F}\end{array}$ & $\begin{array}{l}\text { final energy, in. Ib }=E-E_{L} \\
\text { final ielocity in. } / \mathrm{sec}=\left(2 \mathrm{~g} \mathrm{E}_{\mathrm{F}} / \mathrm{W}\right)^{\mathrm{I}} \mathrm{z} \\
=\left(33 \mathrm{E}_{\mathrm{F}}\right)^{12} \\
\text { final flow, in. }{ }^{3} / \mathrm{sec}=\mathrm{A} \mathrm{V}_{\mathrm{F}}=\left(10.0, \mathrm{~V}_{\mathrm{F}}\right.\end{array}$ & $\begin{array}{l}2112.5 \\
835 \\
835\end{array}$ & $\begin{array}{c}2107.5 \\
83.4 \\
834\end{array}$ & $\begin{array}{c}18925 \\
791 \\
791\end{array}$ & $\begin{array}{r}1889 \\
790 \\
790\end{array}$ \\
\hline $\begin{array}{l}Q_{A} \\
P_{A} \\
F_{A}\end{array}$ & $\begin{array}{l}\text { average flow, in. } 3 / \mathrm{sec}=\left(\bar{Q}+Q_{\mathrm{F}}\right)^{2} \\
\text { average pressure, psi }= \\
\left(\Omega_{\mathrm{A}} / 0.40 \mathrm{~K} \mathrm{C}_{\mathrm{A}} \mathrm{D}_{\mathrm{A}}\right)^{2}=\left(\Omega_{\mathrm{A}} 04 \mathrm{C}_{\mathrm{A}} \mathrm{D}_{\mathrm{A}}\right)^{2} \\
\text { average force, } 1 \mathrm{~b}=\mathrm{A} \mathrm{P}_{\mathrm{A}}=10.0 \mathrm{P}_{\mathrm{A}}\end{array}$ & $\begin{array}{r}8547 \\
102 \\
1020\end{array}$ & $\begin{array}{r}8542 \\
102 \\
1020\end{array}$ & $\begin{array}{l}812.5 \\
108.8 \\
1088\end{array}$ & $\begin{array}{r}8120 \\
108.7 \\
1087\end{array}$ \\
\hline
\end{tabular}


SAMPLE FORCE CURVE

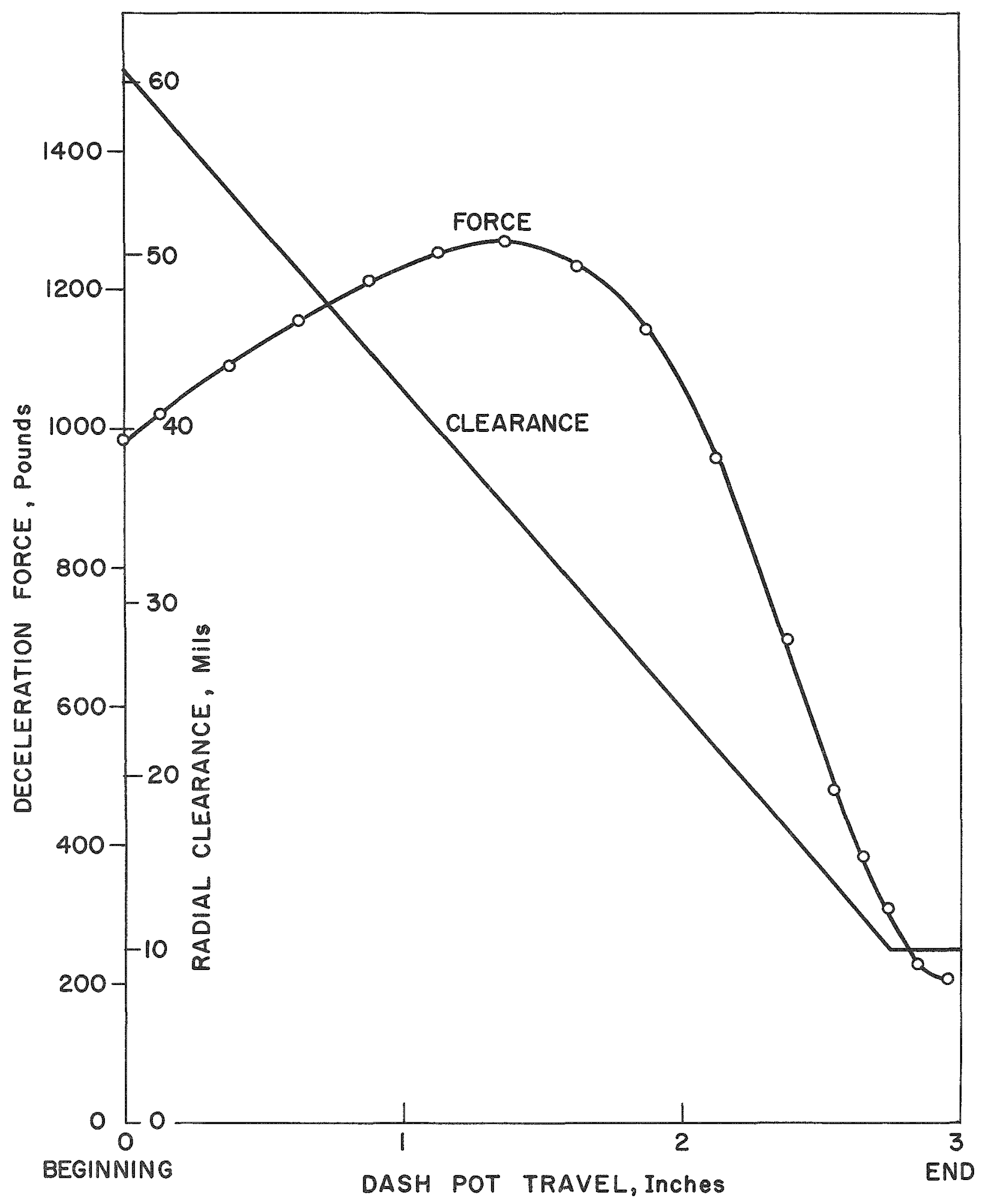




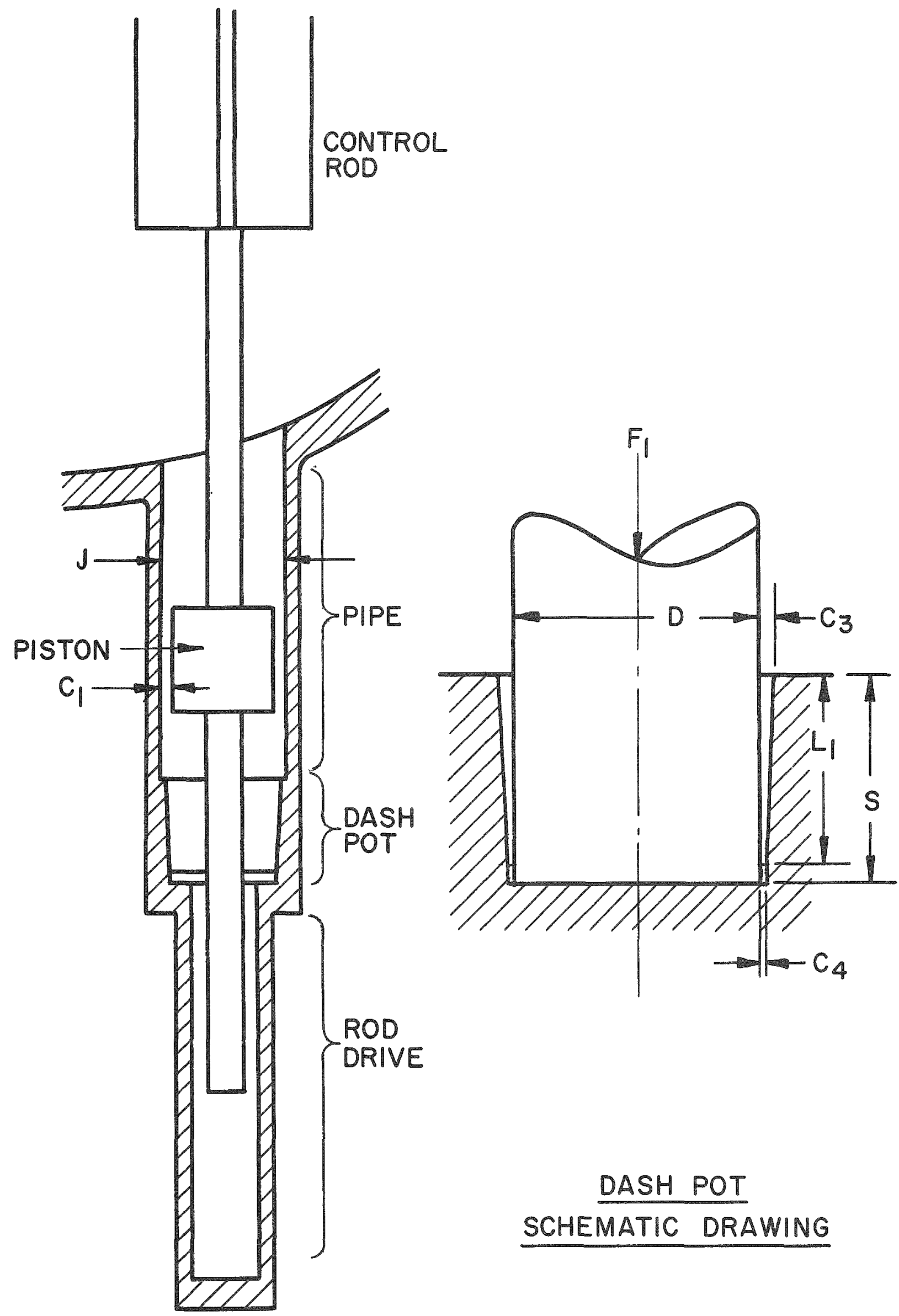


Antigravity-scram Control Rod Drive using the Magnetic Jack

For emergency shutdown of a nuclear reactor by control rods, a force to move the rods must be available under any condition; in the case discussed here, the force must work against gravity. To retain the principal advantage of the magnetic jack the scram device should not use shaft seals or other openings through the reactor vessel. This means that the device must operate in the reactor coolant; therefore, there should be no close-fitting or load-bearing moving parts. Although being required to use an antigravity-scram device complicates the drive somewhat, it has the advantage of balancing the weight of the control rod, thus requiring less load capacity of the drive. This reduces the acceleration and speed of the rod during shutdown, but in most cases this does not matter.

Five Possible Antigravity-scram Methods

\begin{tabular}{|c|c|}
\hline Device & Disadrantages \\
\hline Counterweight & Complicated mechanism; large space. \\
\hline Negator Spring & One break would cause complete fallure; large space. \\
\hline Hydraulic Cylinder & Depends on unfailing supply of water under pressure. \\
\hline Compression Spring & Force varies with position; large space. \\
\hline Tension Spring & $\begin{array}{l}\text { One break would cause complete failure; large space; } \\
\text { force varies with position. }\end{array}$ \\
\hline
\end{tabular}

The force variation of the compression spring device can be reduced by using a larger spring; however, some variation is all right, since the force is least when the rod is being stopped at the end of its travel. The space requirement of the compression spring device can be reduced by using several springs, one inside of another and alternately wound left hand and right hand.

Bottom vs Top Drive using the Magnetic Jack with a Compression Spring Antigravity-scram

\begin{tabular}{|c|c|c|}
\hline & $\begin{array}{c}\text { Advantages of Drive at the } \\
\text { Bottom of the Reactor }\end{array}$ & $\begin{array}{l}\text { Advantages of Drive at the } \\
\text { Top of the Reactor }\end{array}$ \\
\hline $\begin{array}{l}1 . \\
2 . \\
3 .\end{array}$ & $\begin{array}{l}\text { lower temperatures } \\
\text { lower building height } \\
\text { control rod parts are in } \\
\text { compression and therefore } \\
\text { cannot fall apart, thus in- } \\
\text { creasing reactivity } \\
\text { drive rods are in tension } \\
\text { and therefore are less } \\
\text { likely to buckle } \\
\text { water dash pot may be used } \\
\text { no special provisions axe } \\
\text { needed to keep the reactor } \\
\text { heat from the drive } \\
\text { no interference at top of } \\
\text { reactor }\end{array}$ & $\begin{array}{l}\text { 1. less dirt } \\
\text { 2. less basement depth } \\
\text { 3. if the end of the drive blows off, } \\
\text { the control rod will not be } \\
\text { forced down by pressure, thus } \\
\text { increasing reactivity } \\
\text { 4. control rod is pulled thru the } \\
\text { reactor during scram and } \\
\text { therefore is less likely to jam }\end{array}$ \\
\hline
\end{tabular}




\section{Conclusions}

An antigravity-scram control rod drive using the magnetic jack is practical. The scram device recommended in this report requires the length of the drive to be increased by two travel lengths. In the case of a reactor having a control rod travel of $81 \mathrm{in.,} \mathrm{the} \mathrm{drive} \mathrm{would} \mathrm{be} 25 \mathrm{ft} 2 \mathrm{in}$. long. The device would fit in a standard $8 \mathrm{in}$. pipe. The time required to travel the 81 in. during scram would be $2.07 \mathrm{sec}$

Helical compression springs, because of their reliability, would be the best type of device for scramming a control rod against gravity.

The scram device should be located between the magnetic jack drive and the control rod so that the scram device does not interfere with the removal of the magnet coils.

In most cases, the drive should be located below the reactor.

\section{Calculations}

Control rod drive length:

$$
\begin{aligned}
\text { spring travel } & =81 \mathrm{in} . \\
\text { spring, etc. length } & =81 \mathrm{in} . \\
\text { magnetic jack length } & =54 \frac{3}{\mathrm{i}} \mathrm{in} . \\
\text { magnetic jack travel } & =81 \mathrm{in} . \\
\text { blow down valve length } & =4 \frac{1}{\mathrm{in}} \mathrm{in} \\
\text { Total length } & =302 \mathrm{in.}=25 \mathrm{ft} 2 \mathrm{in} .
\end{aligned}
$$

Control rod assembly net weight (1b):

fuel and absorber rod seven $\frac{1}{2}$ in. dia. drive rods, $11 \mathrm{ft}$ long extension rod, $1 \frac{\pi}{2}$ in pipe $10 \mathrm{ft}$ long connectors, etc. (estimated) W

buoyancy (half submerged)
$=360$

$=51.5$

$=27.2$

$=11.3$

$450 \mathrm{lb}$ in air

$=-30$

$420 \mathrm{lb}$ in boiling water

pressure drop across core

cross-sectional area of rod

pressure drop force $=(2.5)(18.5)=-46.2 \mathrm{lb}$
$=25 \mathrm{psi}$

$=18.5$ in. $^{2}$

$=+16.21 \mathrm{~b}$ 
Compression spring forces:
coil housing I.D.
$=7.98 \mathrm{in}$.
solid length of active coils $=70 \mathrm{in}$.
maximum stress in wire $=50,000 \mathrm{psi}$
diametral clearances $\quad=\frac{1}{16}$ in
number of springs
$=7$

\begin{tabular}{|c|c|c|c|c|c|c|}
\hline $\begin{array}{c}\text { mean } \\
\text { dia. }\end{array}$ & $\begin{array}{l}\text { wire } \\
\text { dia. }\end{array}$ & $\begin{array}{l}\max . \\
\text { load }\end{array}$ & $\begin{array}{l}\text { active } \\
\text { coils } \\
\end{array}$ & $\begin{array}{c}1 \mathrm{~b} \\
\text { inch } \\
\end{array}$ & $\begin{array}{c}\text { def1., } \\
\text { in. }\end{array}$ & $\begin{array}{l}\text { load } \\
\text { at } 81 \text { in. }\end{array}$ \\
\hline 7.562 & 0.375 & 135 & 187 & 0.34 & 397 & 107 \\
\hline 6.781 & 0.344 & 118 & 203 & 0.31 & 380 & 93 \\
\hline 6.062 & 0.312 & 97 & 224 & 0.27 & 359 & 75 \\
\hline 5.406 & 0.281 & 81 & 250 & 0.22 & 368 & 63 \\
\hline 4.812 & 0.250 & 64 & 280 & 0.17 & 376 & 50 \\
\hline 4.281 & 0.219 & 47 & 319 & 0.125 & 376 & 37 \\
\hline 3.812 & 0.187 & 34 & 374 & 0.082 & 415 & 28 \\
\hline \multicolumn{2}{|c|}{ total force } & 576 & & & & 453 \\
\hline
\end{tabular}

Net scram force:

spring force at bottom position $=576$

net weight $=-390$

F scram force at bottom position $=186$ pounds

spring force at top position $=453$

net weight $=-390$

scram force at top position $=63$ pounds

Time to scram rod:

$a_{0}$ initial acceleration $=F g / W=(186)(32.2) / 450=13.3 \mathrm{ft} / \mathrm{sec}^{2}$

$\mathrm{s}_{0-2}$ with a certain dash pot piston orificing (before entering the dash pot), the distance to reach

terminal velocity would $=2 \mathrm{ft}$

$a_{0-2}$ average acceleration $=\left(a_{0}+a_{2}\right) / 2=(13.3+0) / 2=6.65 \mathrm{ft} / \mathrm{sec}^{2}$

$\mathrm{v}_{2}$ terminal velocity $=\left(2 \mathrm{a}_{0-2} \mathrm{~s}_{0-2}\right)^{\mathrm{l} / 2}=[(2)(6.65)(2)]^{1 / 2}=5.16 \mathrm{ft} / \mathrm{sec}$

$t_{0-2}$ time to reach terminal velocity $=\left(2 s_{0-2} / a_{0-2}\right)^{1 / 2}$ $=[(2)(2) / 6.65]^{1 / 2}$

$=0.77 \mathrm{sec}$

$\mathrm{F}_{2}$ scram force at the 2-ft point

$=147 \mathrm{lb}$

distance to the beginning of slowing down by

by dash pot

$=6 \mathrm{ft}$

$F_{6}$ scram force at the 6-ft point

$=771 \mathrm{~b}$ 


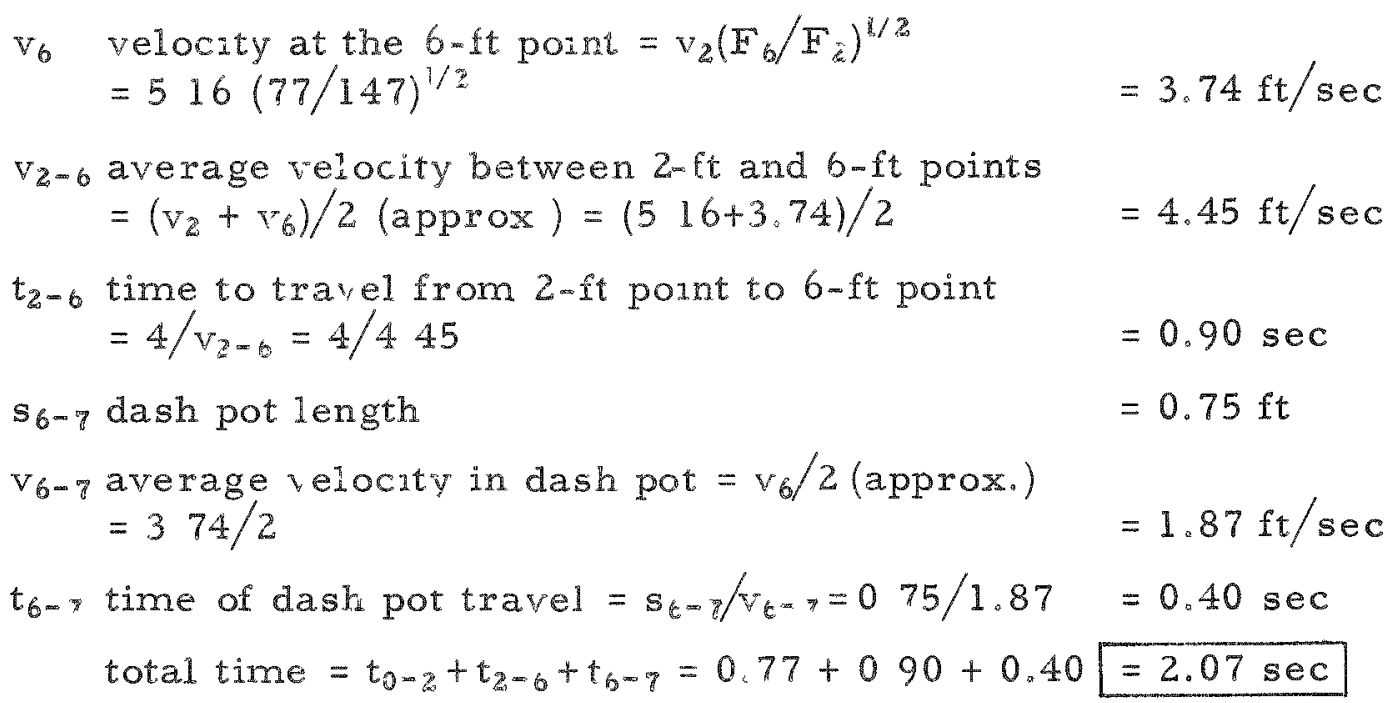

Heating Test of Hold Coil \#29

A coil (see page 105) was supplied with an increasing amount of DC voltage until it burned out. The coil operated for 68 hours at $300 \mathrm{~F}$ and for 168 hours at $450 \mathrm{~F}$ with no sign of failure Then, after a short time at $500 \mathrm{~F}$, the epoxy resin began to give off fumes After 116 hours at $550 \mathrm{~F}$ and a few hours at $680 \mathrm{~F}$, the epoxy resin became chared, thus reducing its thermal conductivity and causing the wre temperalure to rise to $720 \mathrm{~F}$. After 16 hours at $720 \mathrm{~F}, 24$ hours at $780 \mathrm{~F}$ and about 48 hours at $800 \mathrm{~F}$, the coil failed by short circuiring The short circuit was probably caused by the carbon which was formed as the epoxy resin charred.

The coil was tested under conditions which simulated those of a coil in a drive operating in $68 \mathrm{~F}$ still air To simulate the effect of adjacent coils, the test coil had each end corered with a 1 in. thick disc of asbestos board. The temperature of the cols was measured by measuring the resistance of the coil with a voltmeter and an ammeter This gave the average wire temperature which was close to the temperature of the center windings (maximum temperature) and close to the temperature of the iron shell (minimum temperature), since the coll is thoroughly impregnated.

The heatirg curves were calculated trom coefficients given in $\mathrm{Ma}$ chinery Handbook, eleventh edition page 1660. The surface area of the coil was assumed to be 329 square inches, which 15 the area of the periphery plus $8.2 \%$ of the exposed area of the ends This $82 \%$ represents the effect of the small space between the colls in the jack assembly. 


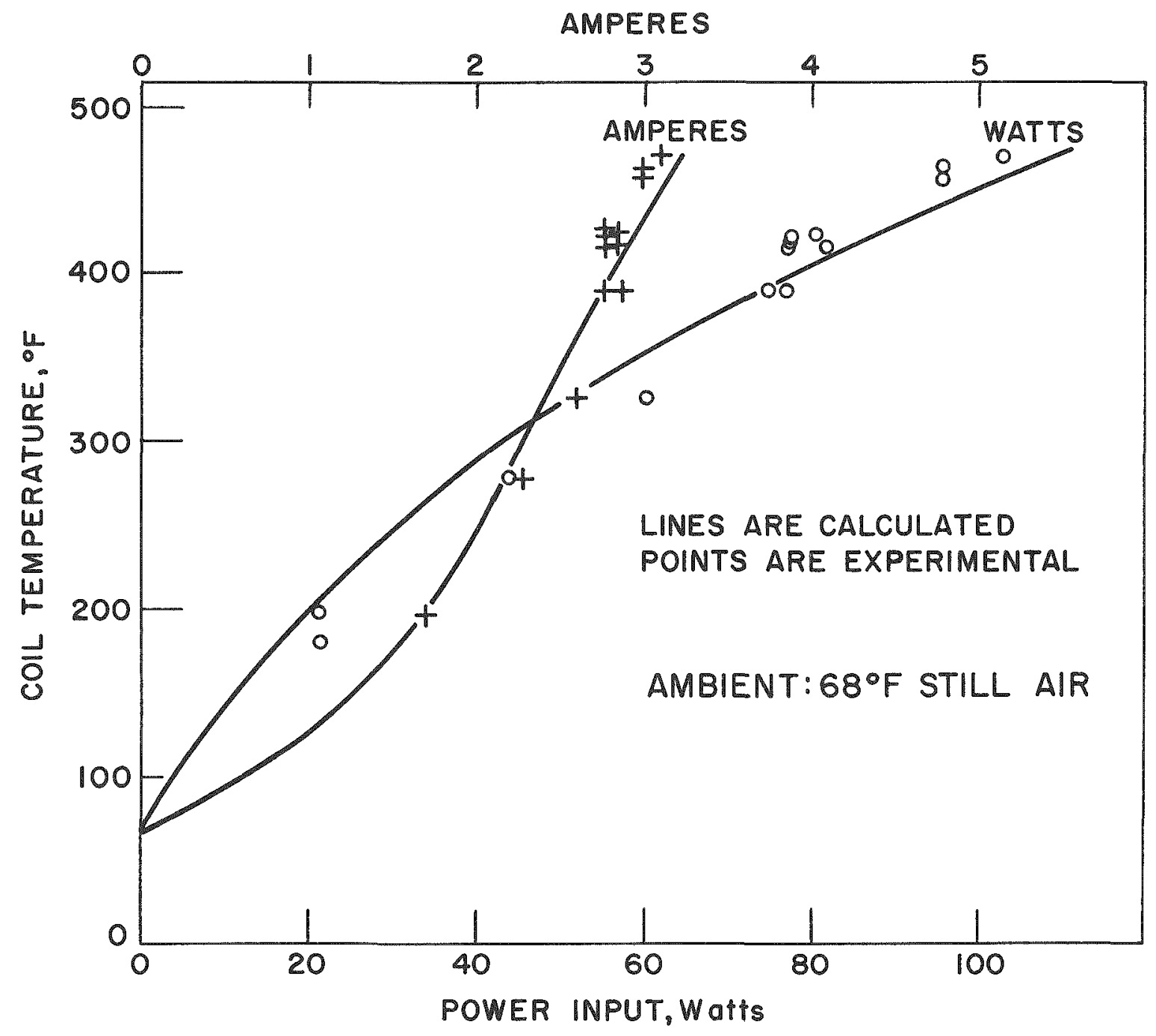

HEATING TEST OF HOLD COIL \#29 


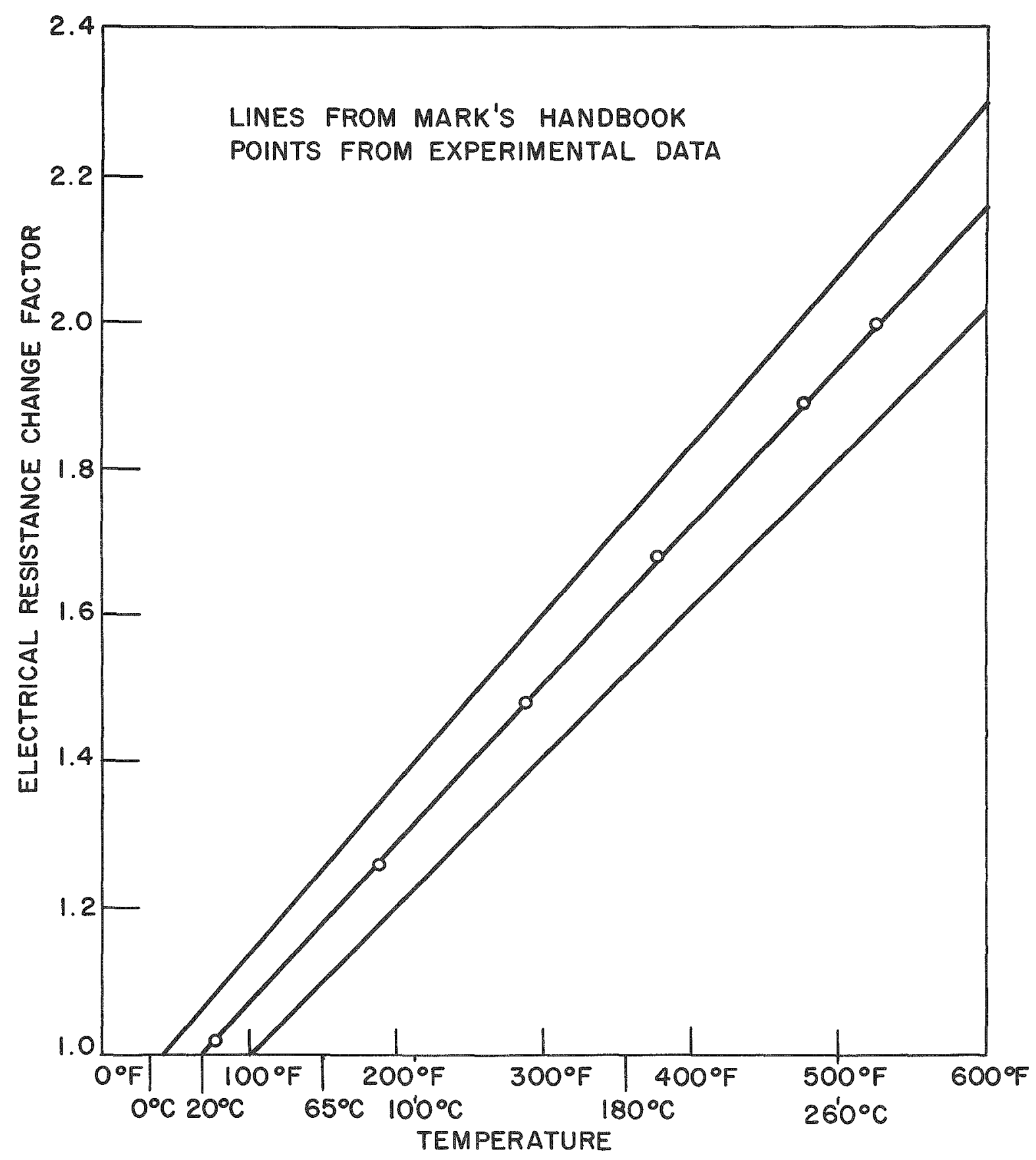

THERMAL COEFFICIENT OF ELECTRICAL RESISTANCE FOR COPPER MAGNET WIRE 


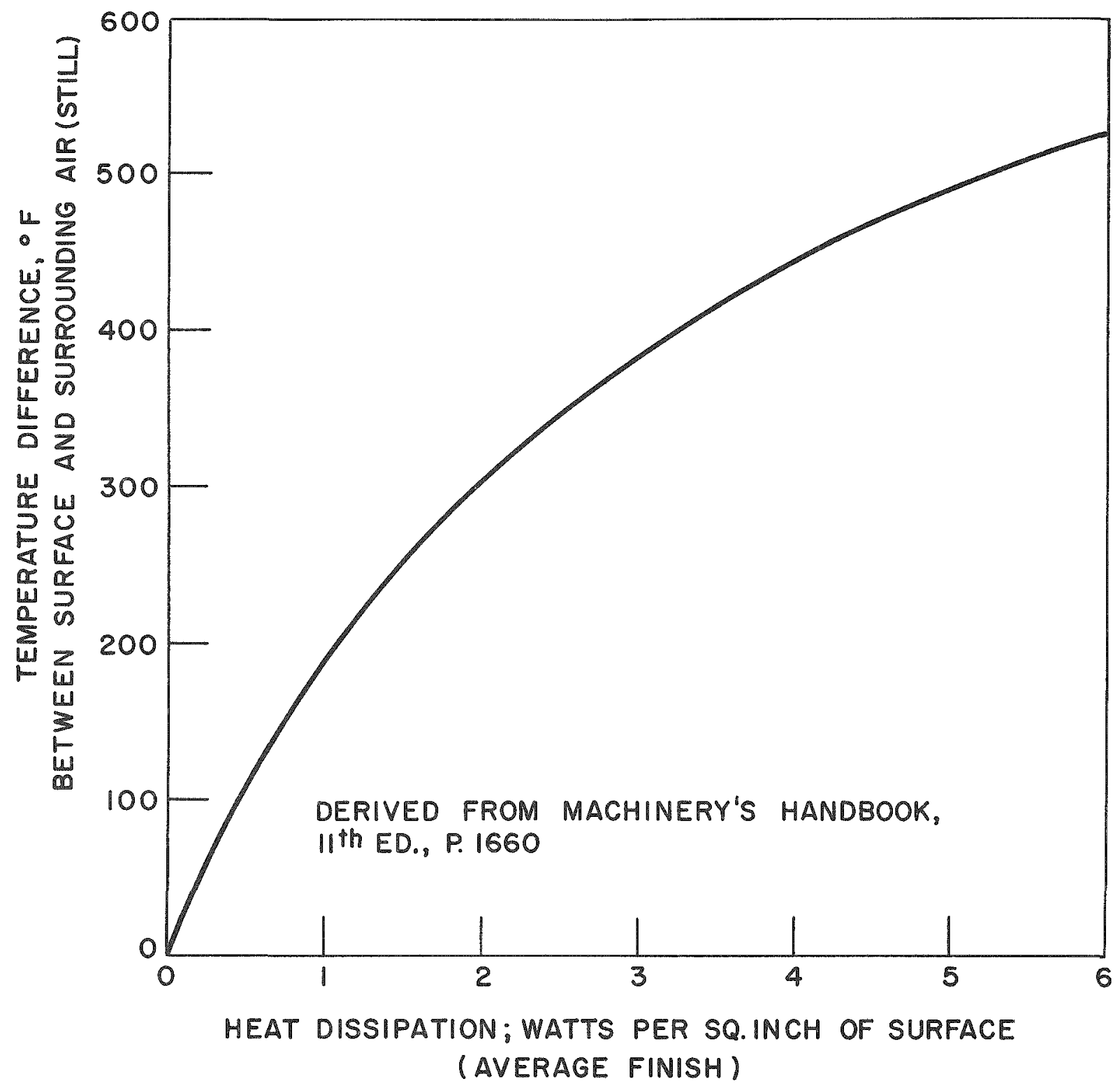

TYPICAL HEAT DISSIPATION CURVE 


\section{APPENDIX B}

JACK DRIVE FOR ALPR $(S L-1)$

Introduction

The SL-1 (ALPR) magnetic jack (\#27) is designed for low pressure and minimum length. This report describes the installation and operation of one magnetic jack control rod drive and gives detailed information on the construction of the magnetic jack, the control rod connection, the position indicator, the control and the power supply. A description of the electrical circuit for five jack drives is given at the end of Appendix B.

The magnetic jack control rod drive system consists of the following as semblies:

A. The jack is pre-assembled for shipping and installation. It consists of:

1. the parts listed on page 44 (drawing RE-1-20471 D) except the drive rod (part \#8) and the position indicator rod (part \#9):

2. the adapter flange (drawing $R E-1-22615-B$ ) on page 62 :

3. the position indicator coil assembly on page 68 ;

4. a high-temperature, flexible cable assembly.

B. The rod connection device is shipped and installed unassembled. It consists of:

1. the parts listed on page $60 \%$

2. the drive rod and the position indicator rod shown on page 57 .

C. The position indicator components are mounted on the instrument panel. They are:

1. the power supply shown on page 69 :

2. the selector shown on page 70 ;

3. the meter shown on page 70 .

D. The jack power supply components may be mounted away from the instrument panel. They are

1. the coil sequence switch shown on page 74 :

2. the rectifier assembly shown on page 75 . 


\begin{tabular}{lr|r|r|} 
& \multicolumn{1}{r}{$100^{\circ} \mathrm{F}$} & $350^{\circ} \mathrm{F}$ \\
\hline Design Pressure, & P.S.I. & 505 & 490 \\
Maximum Capacity $(f=.45)$, & Lbs. & 450 & 340 \\
Rated Capacity, & Lbs. & 150 & 110 \\
Power for Holding, & Watts & 400 & 270 \\
Power for Moving, & Watts & 1720 & 1150 \\
\hline
\end{tabular}

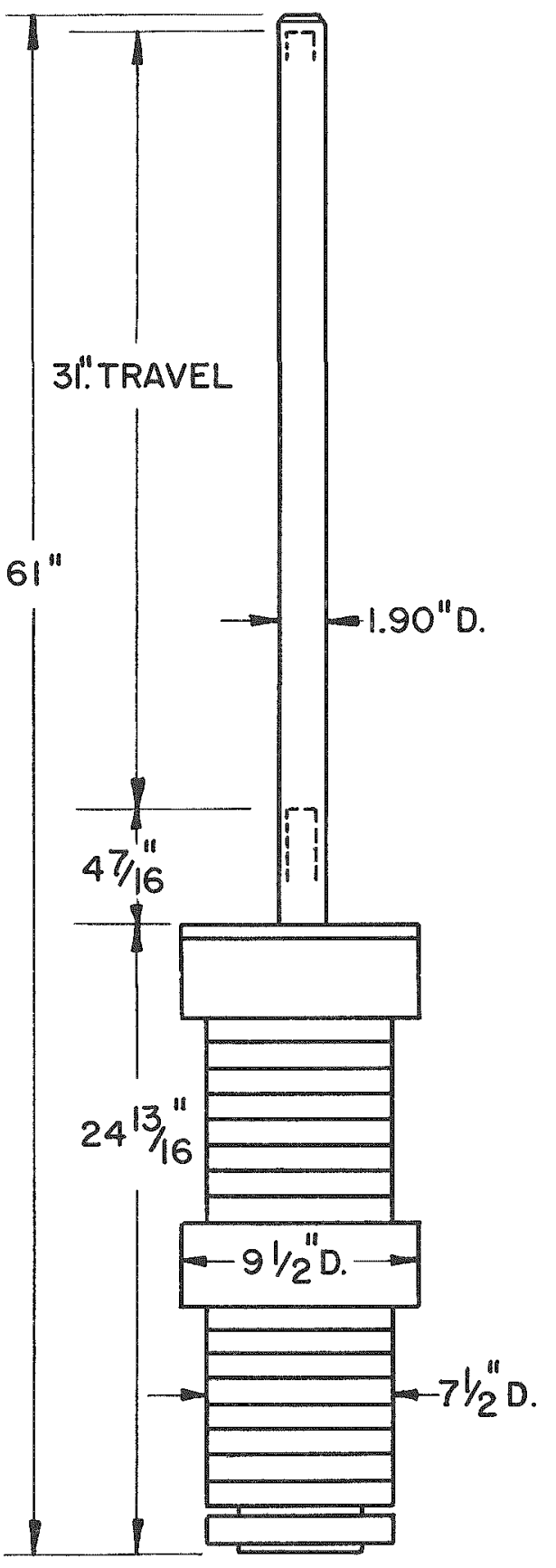




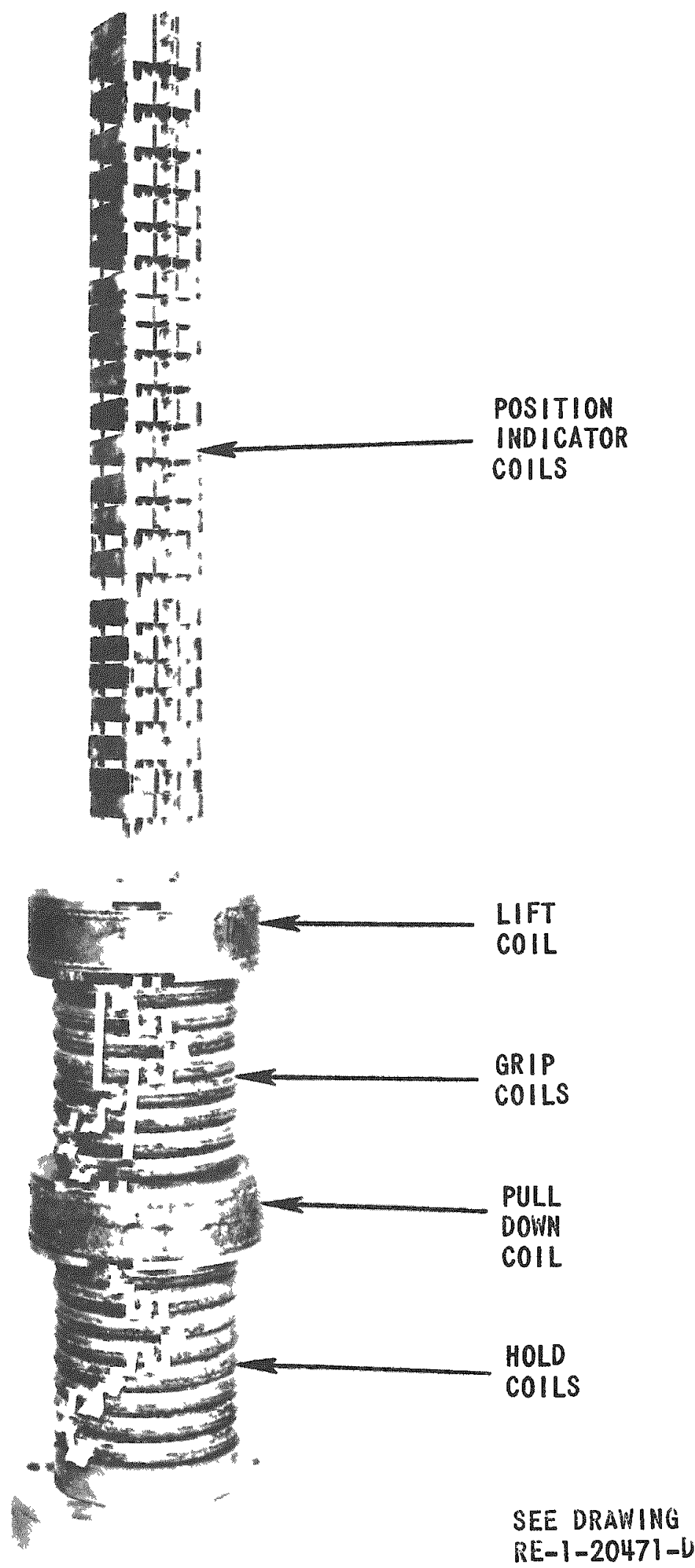

$111-7508$

MAGNETIC JACK HET 


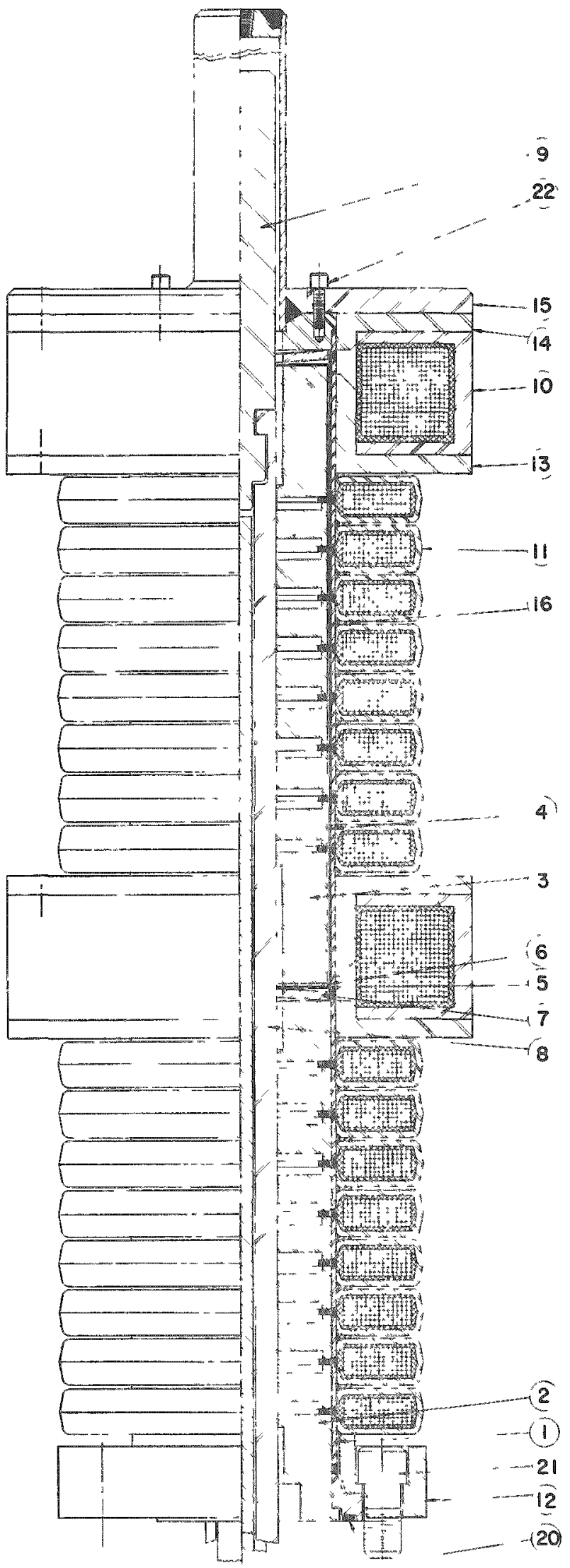

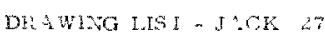

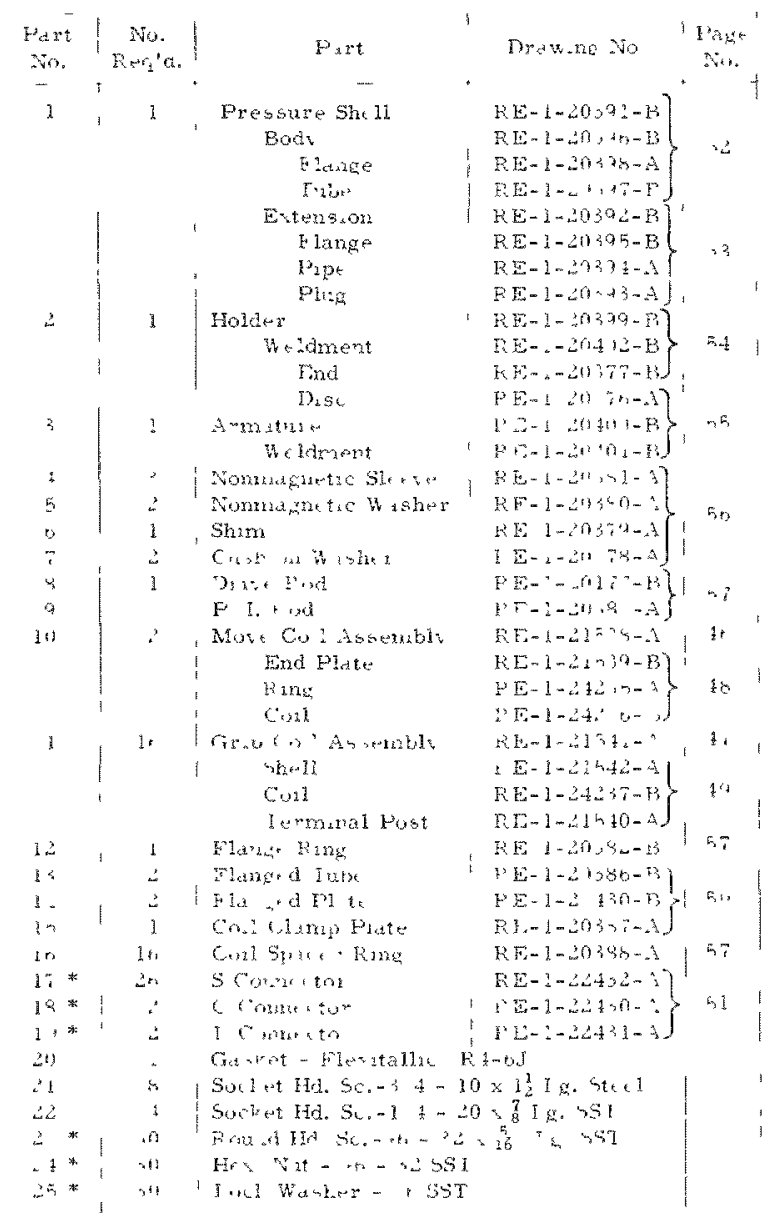

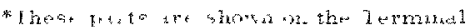

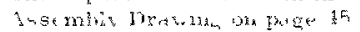

MAGNETIC JACK W27

RE-1-20471-D 


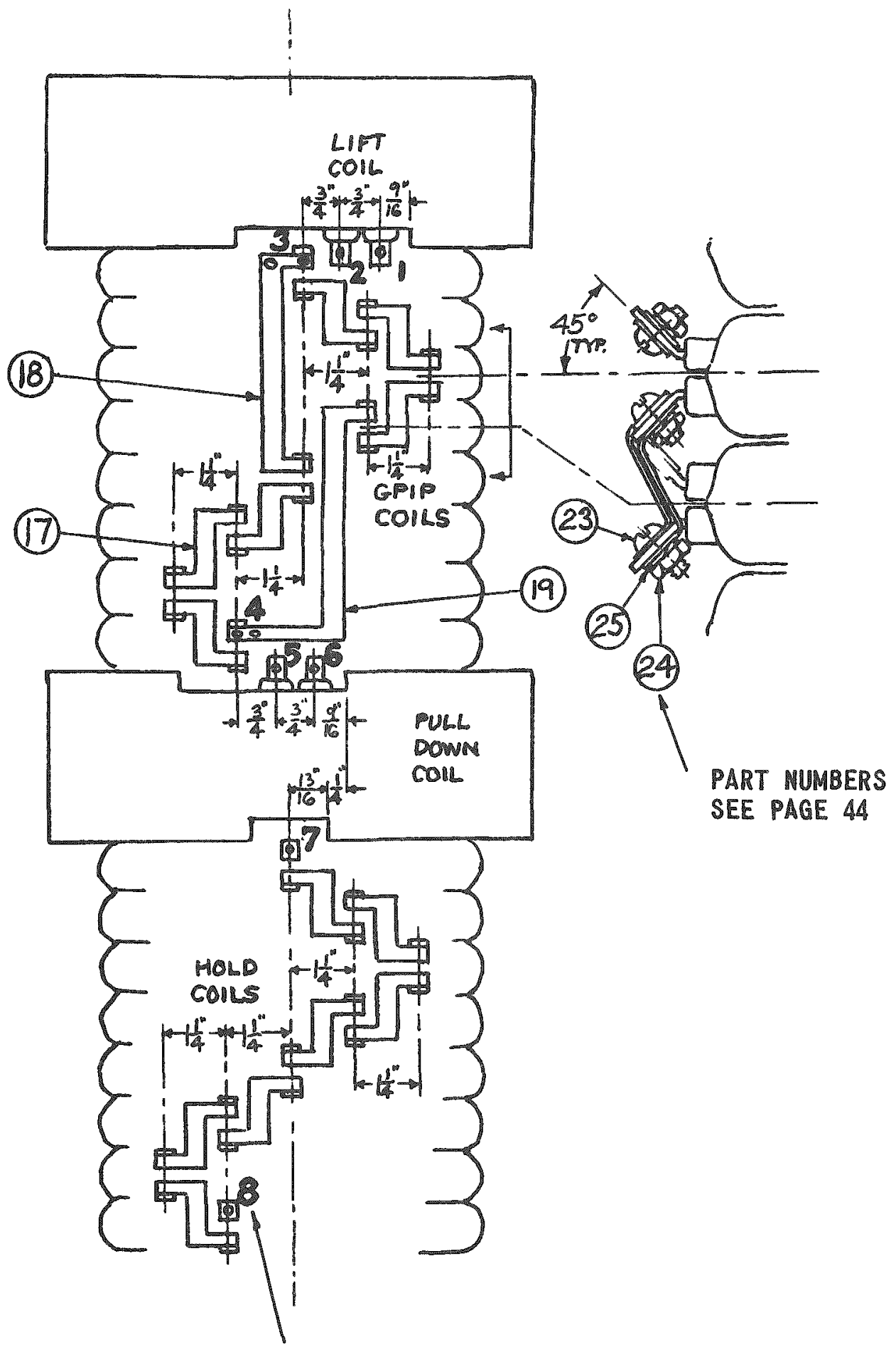

TERMINAL NUMBERS

SEE PAGES $72 \& 75$

COIL TERMINAL CONNECTIONS 

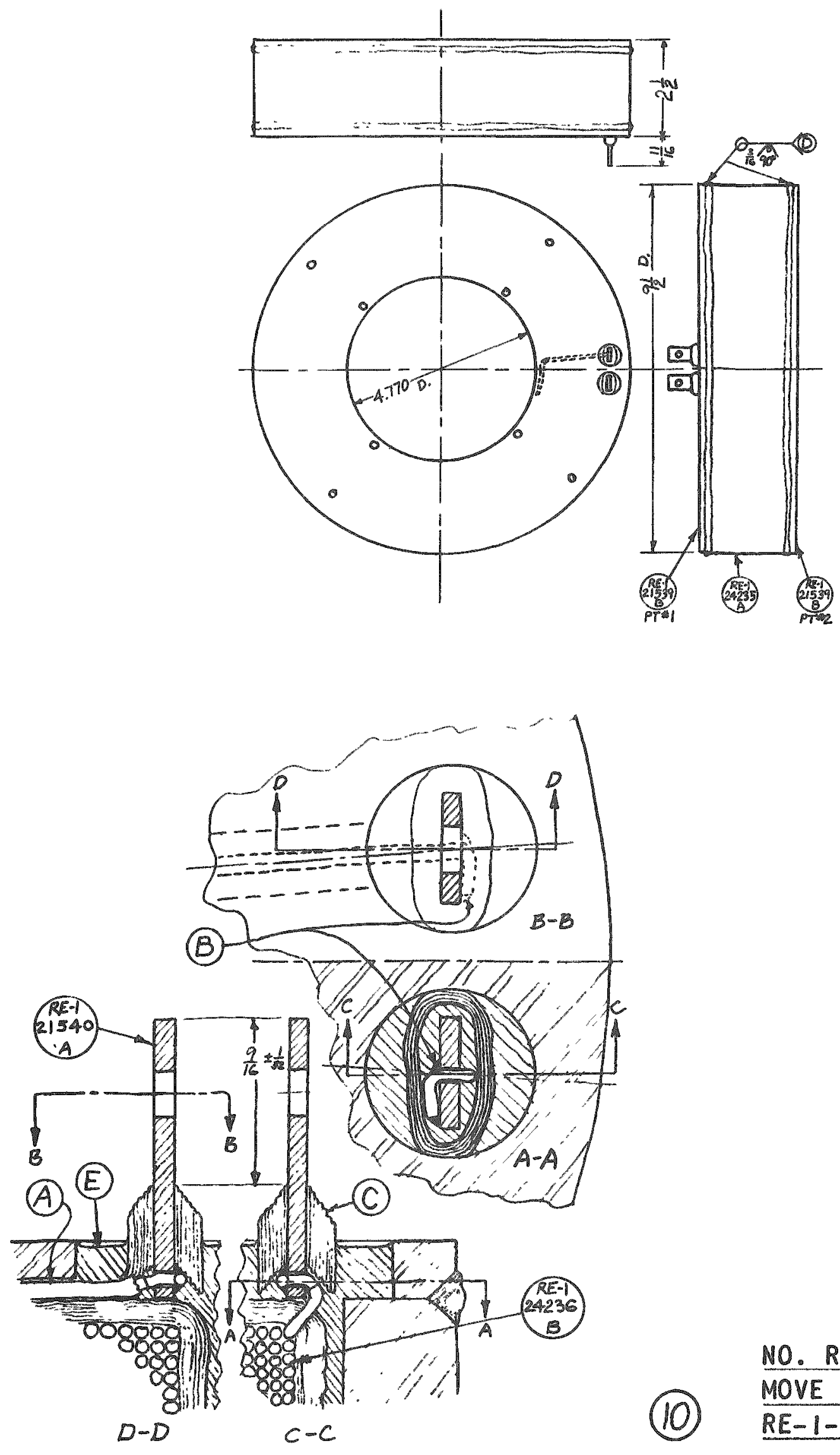

NO. REQUIRED: 2

(10) $\frac{\text { MOVE COIL ASSEMBLY }}{R E-1-21538-A}$ 


\section{COIL ASSEMBLY NOTES - JACK \#27}

(A) Slip glass cloth sleeving over the long lead wire.

(B) Silver solder the wire connections with "Easy-Flo."

(C) Wrap the terminals $\frac{3}{32}$ "thick with $\frac{3}{8} "$ wide untreated glass cloth tape.

(D) Clean the steel parts to provide a good bond with the potting material. Clamp the steel parts and the coil in the welding jig and weld as shown using mild steel weld rod.

(E) Clamp the welded assembly in the teflon mold and vacuum impregnate with epoxy resin prepared as follows: to Shell Epon Resin 815 add $7.5 \%$ by weight of MMM Cardelite N.C. 513; heat mixture to $140^{\circ} \mathrm{F}$; to mixture add $14 \%$ by weight of Shell Epon Curing Agent CL (heated until melted); stix well; use immediately. Place filled mold in $200^{\circ} \mathrm{F}$ furnace for two (2) hours.
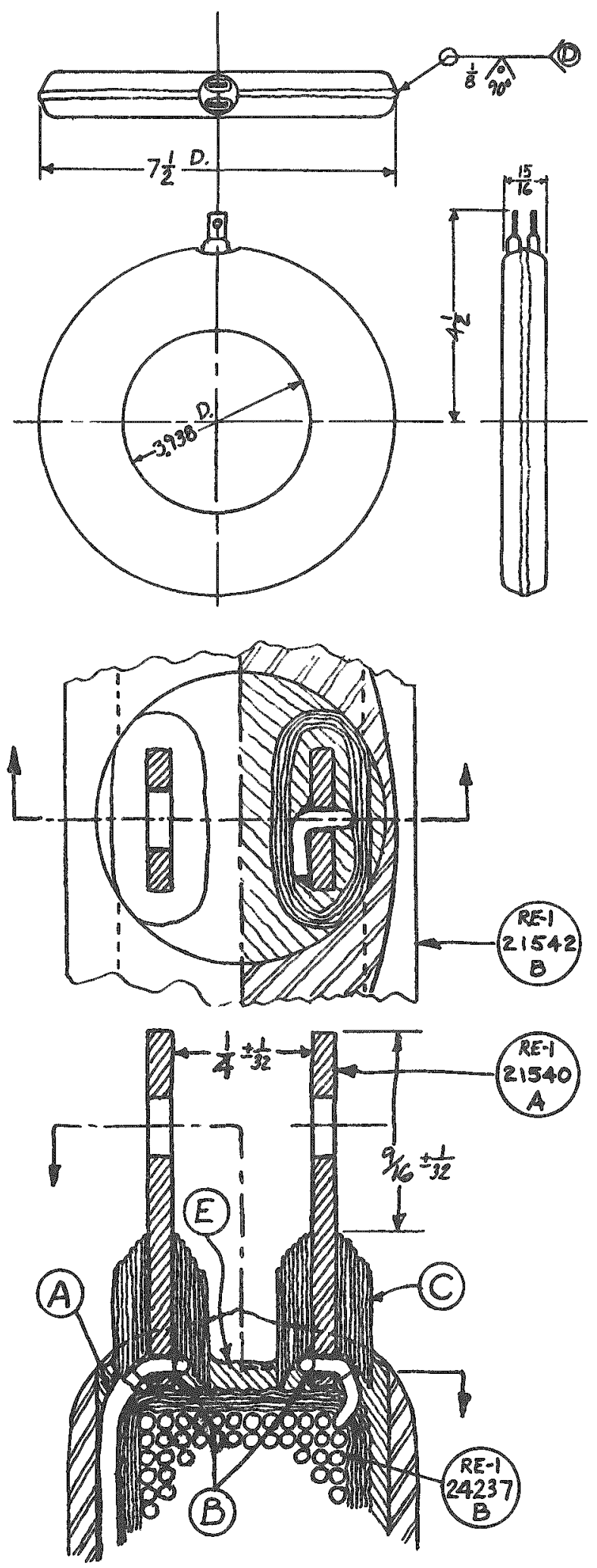

NO. REQUIRED: 18 GRIP COIL ASSEMBLY RE-1-21541-B 

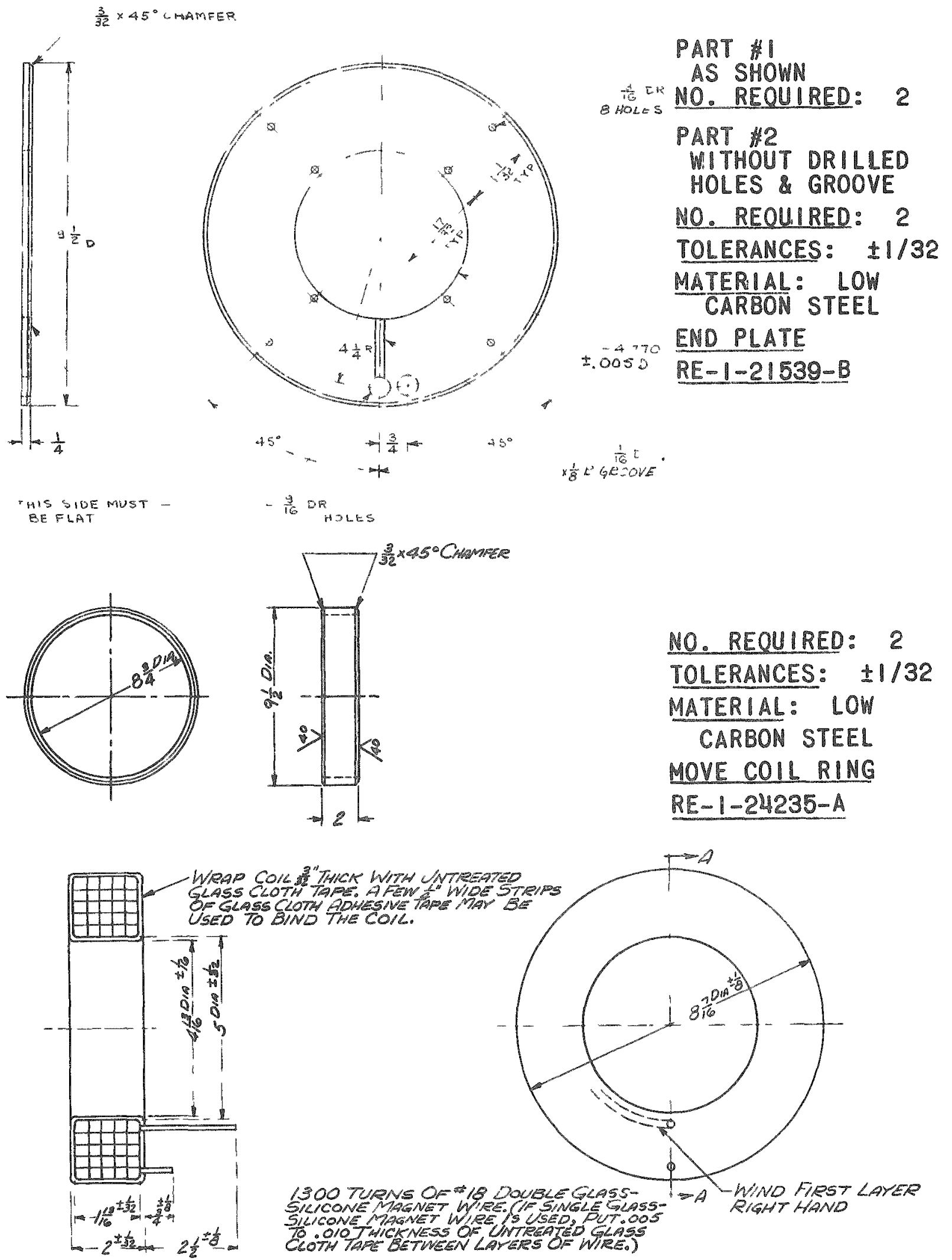

SECTION "A-A"

NO. REQUIRED: 2 MOVE COIL RE-1-24236-B 

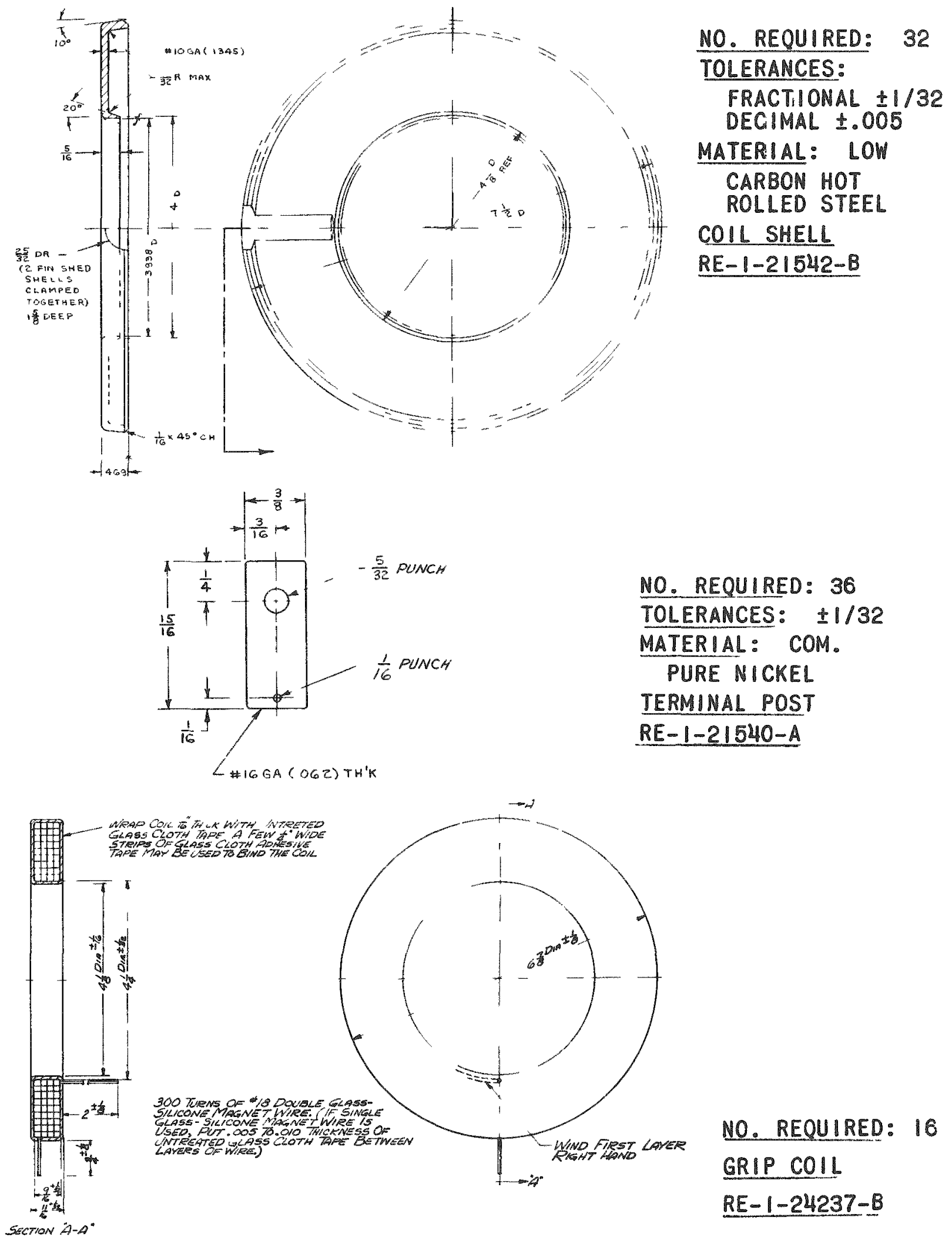

NO. REQUIRED: 16 GRIP COIL

RE-1-24237-B 


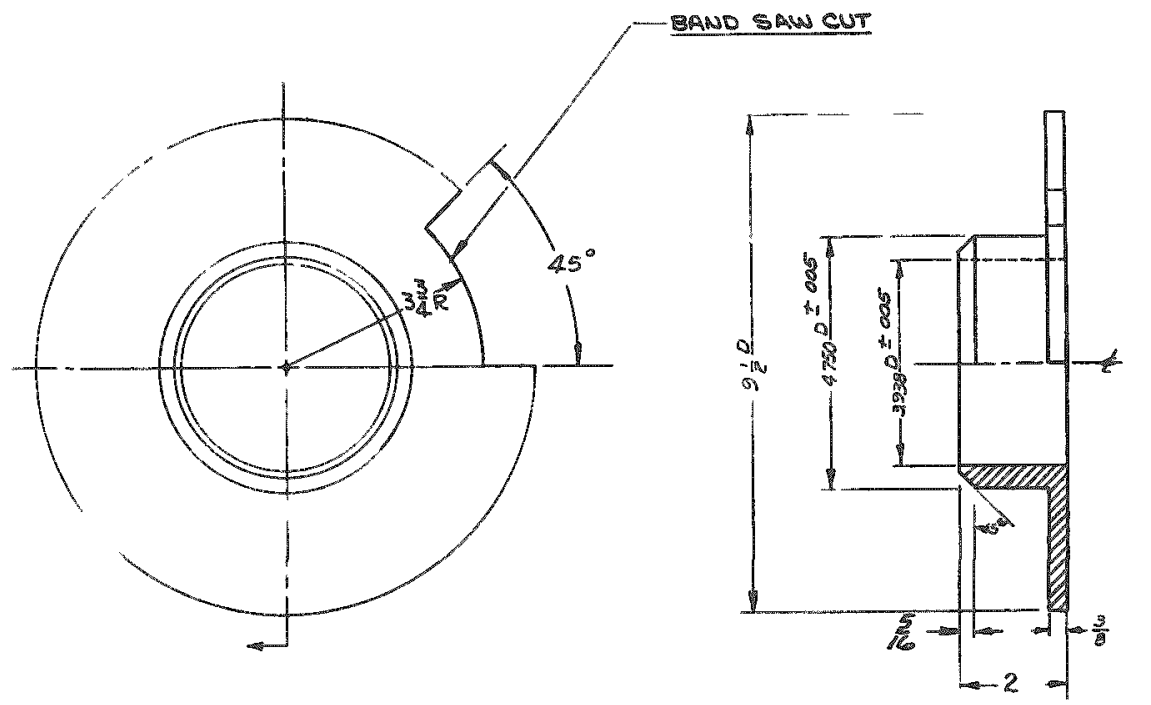

NO. REOUIRED: 2

TOLERAMCES: $\pm 1 / 32$

MATERIAL: LOW

CARBON STEEL

FLAMGED TUBE

RE- $1-20386-8$

(13)

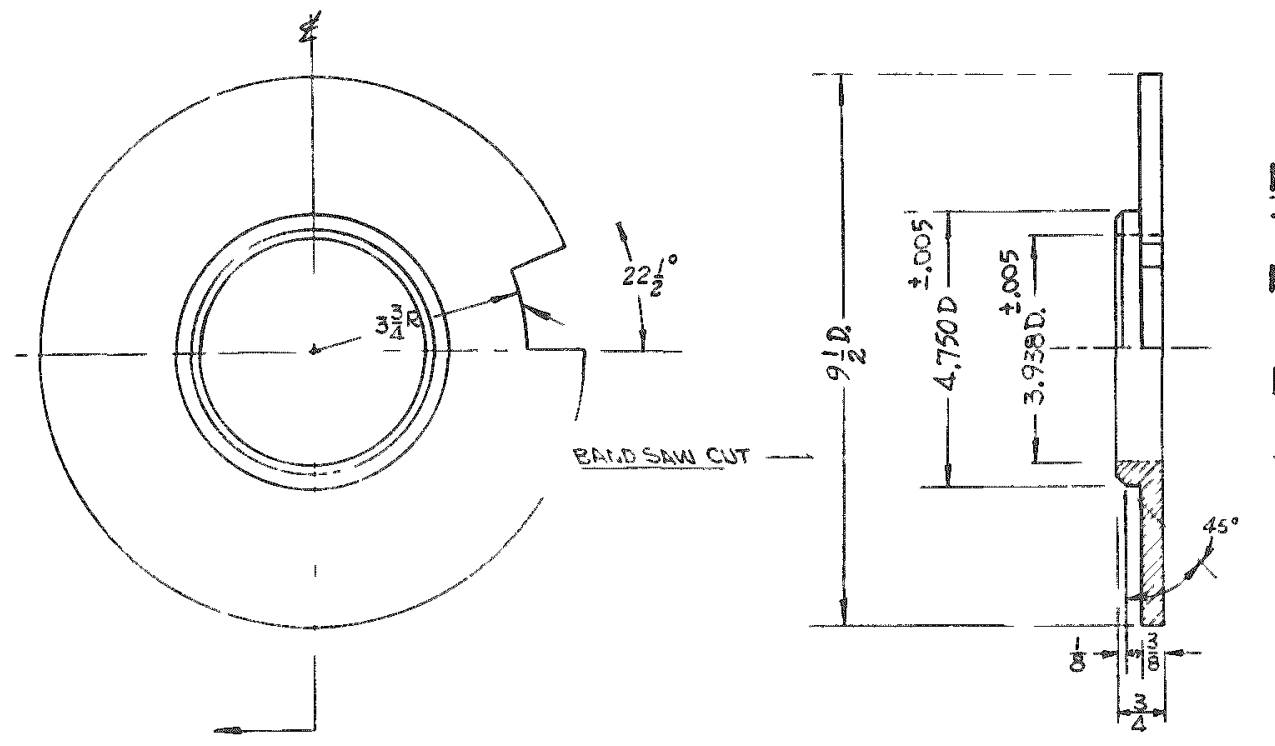

NO. REOUIRED: 2

TOLERANCES: $1 / 132$

MATERIAL: LOW

CARBON STEEL

FLANGED PLATE

RE-1-23430-B

(14)

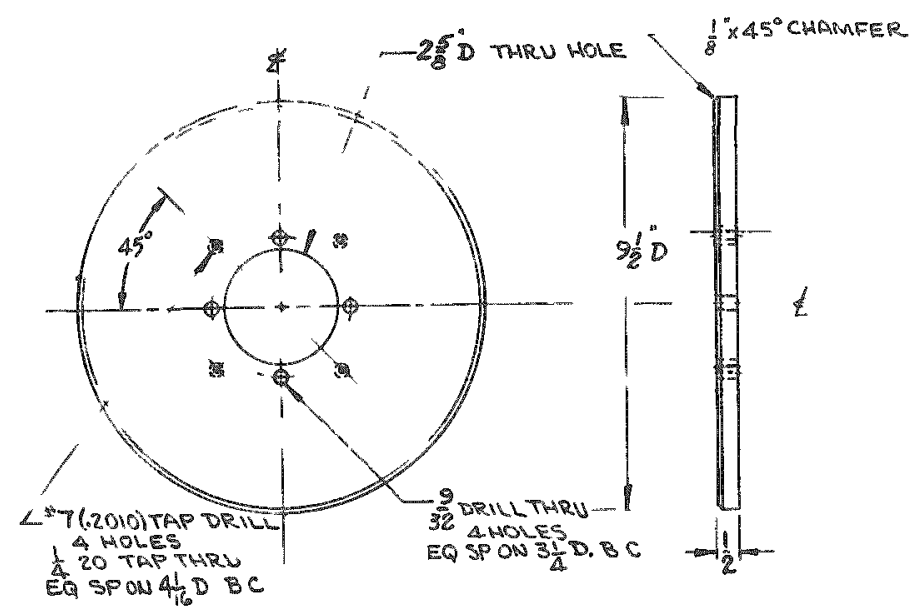

NO. REOUIRED: I

TOLERANCES: $1 / 32$

MATERIAL: LOW

CARBON STEEL

COIL CLAMP

RE-1-20387-A

(15) 


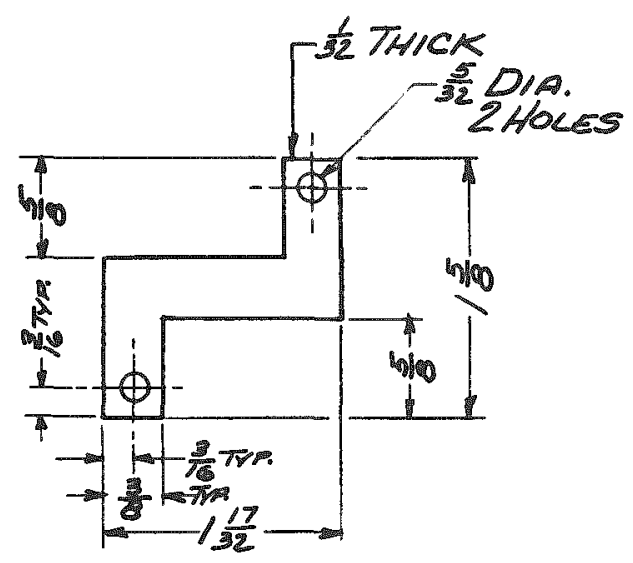

NO. REQUIRED: 26

TOLERANCES: $\pm 1 / 32$

MATERIAL: COM.

PURE NICKEL

"S" CONNECTOR

RE-1-22432-A

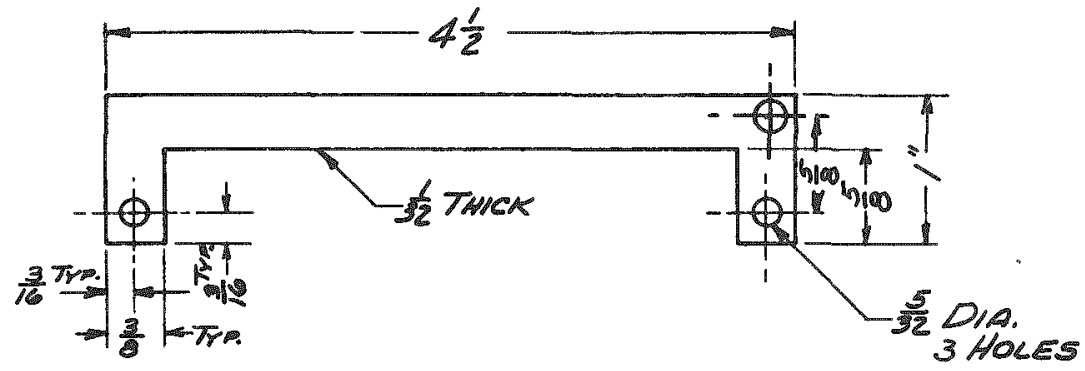

NO. REQUIRED: 2 TOLERANCES: $\pm 1 / 32$ MATERIAL: COM. PURE NICKEL "C" CONNECTOR RE-1-22430-A

(18)

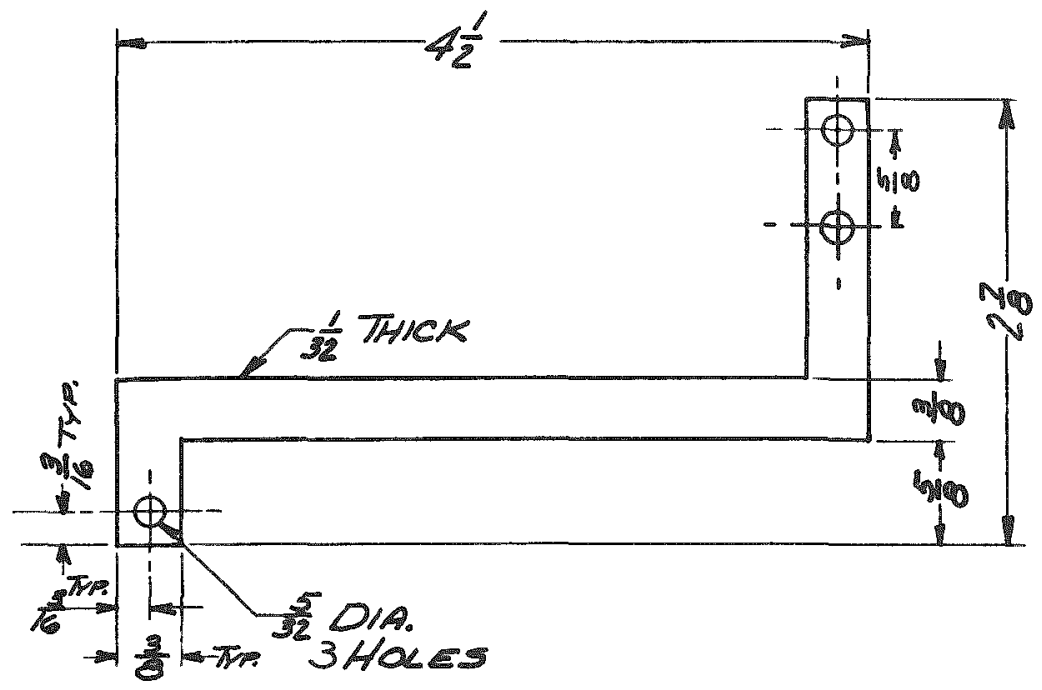

NO. REQUIRED: 2 TOLERANCES: $\pm 1 / 32$ MATERIAL: COM. PURE NICKEL "L" CONNECTOR RE-|-2243|-A 


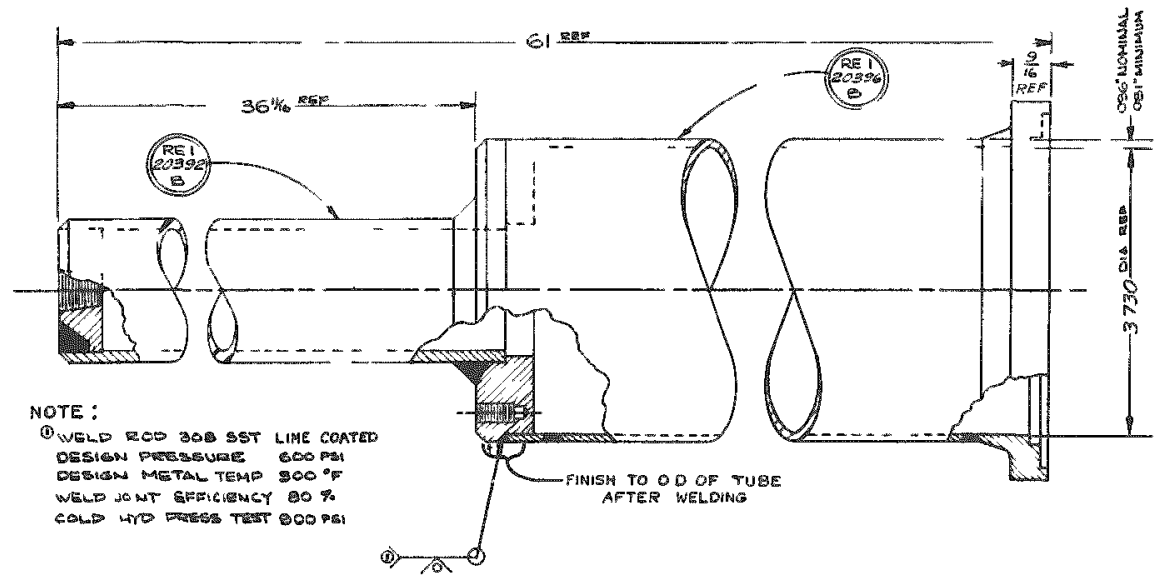

MO. REQUIRED: I

PRESSURE SHELL

RE-1-20391-B

(1)

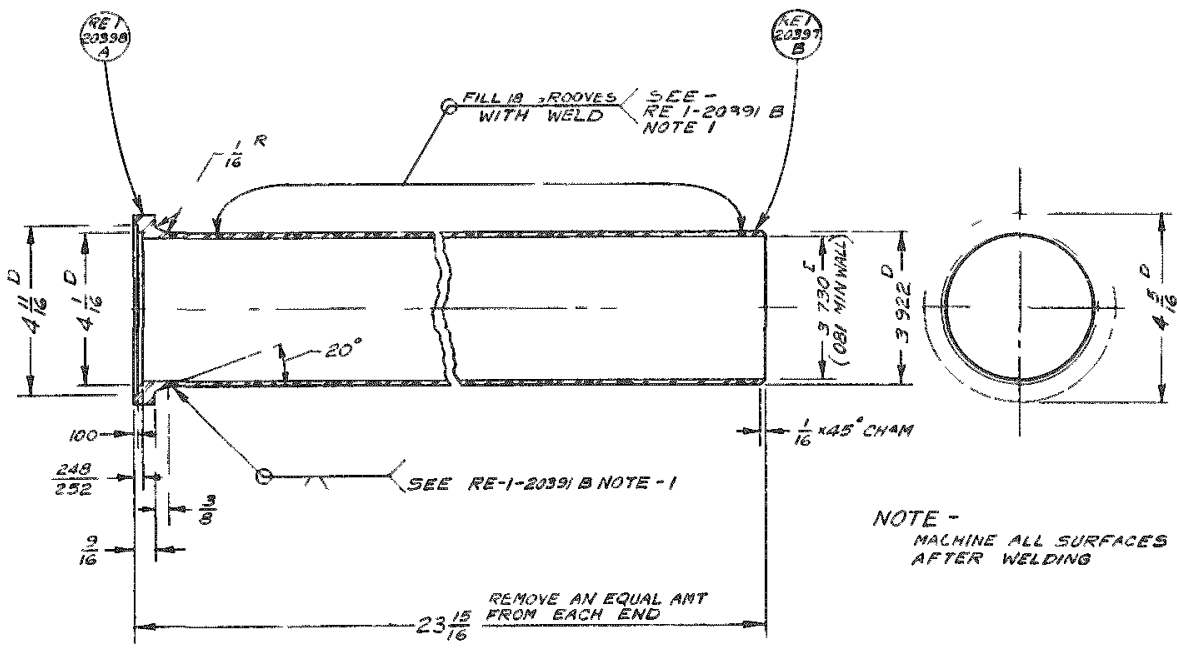

MO. REQUIRED: I

TOLERAMCES:

FRACTIONAL $\pm \frac{1}{64}$

DECIMAL \pm .005

LARGE END

$R E-1=20396-B$

OTE

NO. REQUIRED: I

TOLERAMCES:

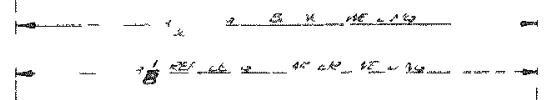

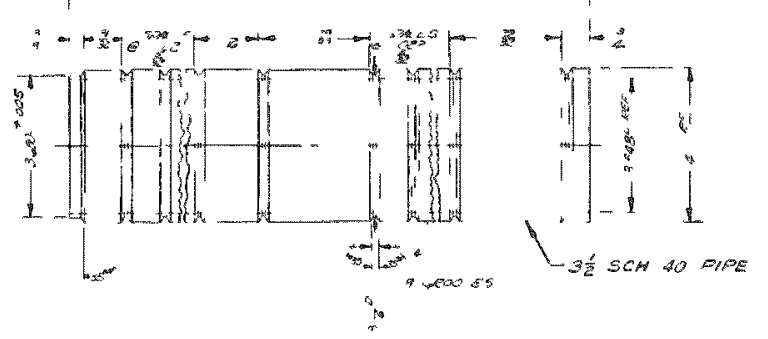

FRACTIONAL $\pm \frac{1}{64}$

DECIMAL \pm .005

AMGLE $\pm 2^{\circ}$

MATERIAL: 405 SST

LARGE END PIPE

$R E-1=20397-B$

MO. REQUIRED: I

TOLERAMCES:

FRACTIOMAL $\pm \frac{1}{32}$

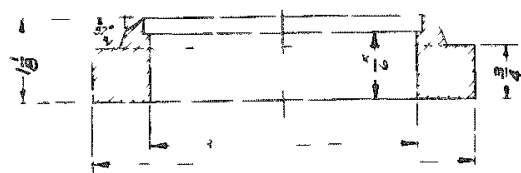

AMGLE $\pm 2^{\circ}$

MATERIAL: 304 SST

LARGE END FLANGE

RE- I - 20398 - A 

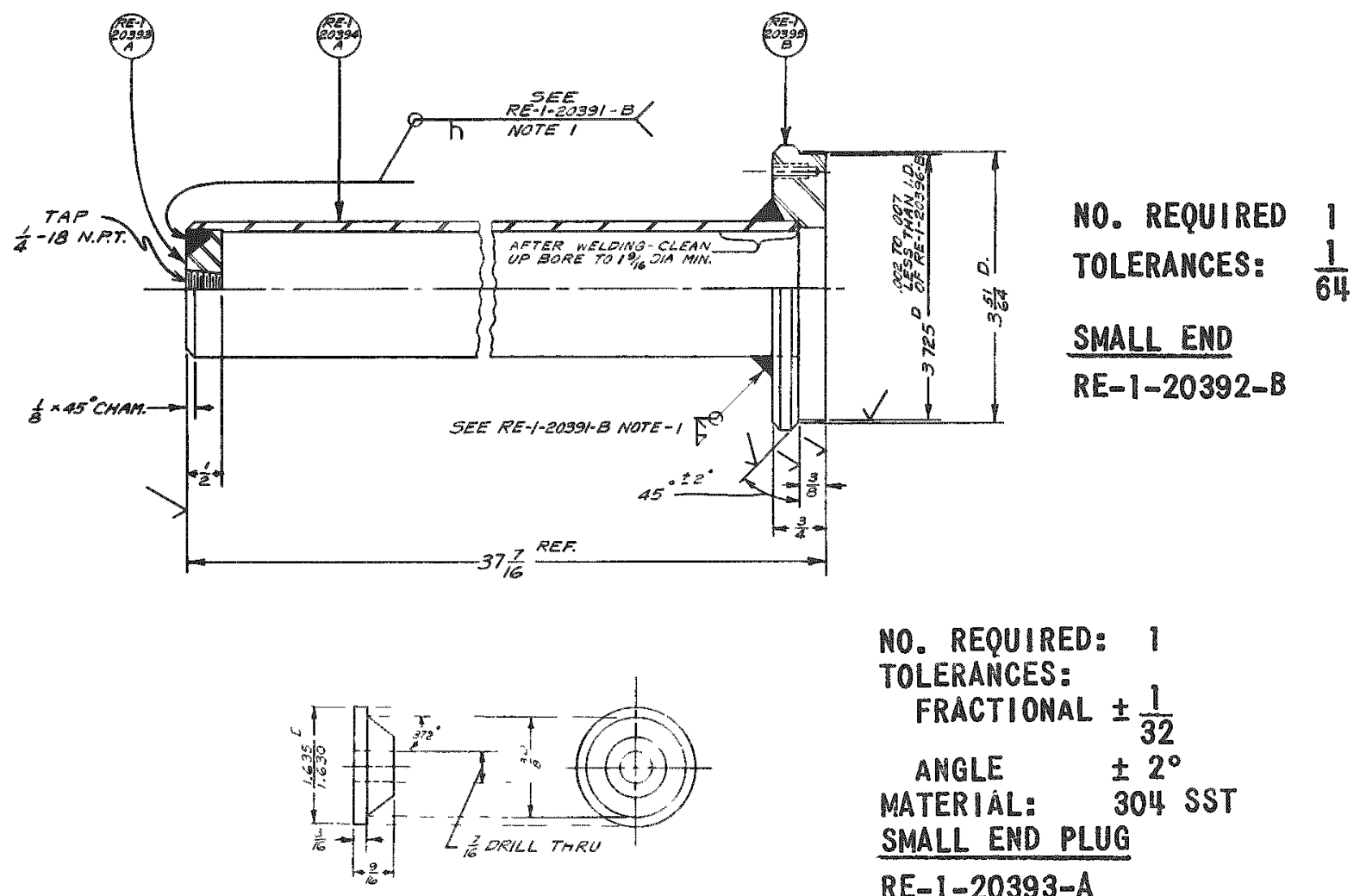

NO. REQUIRED: I

TOLERANCES:

FRACTIONAL $\pm \frac{1}{32}$

AHGLE $\quad \pm 2^{\circ}$

MATERIAL: 304 SST

SMALL END PLUG

$R E-[-20393-A$

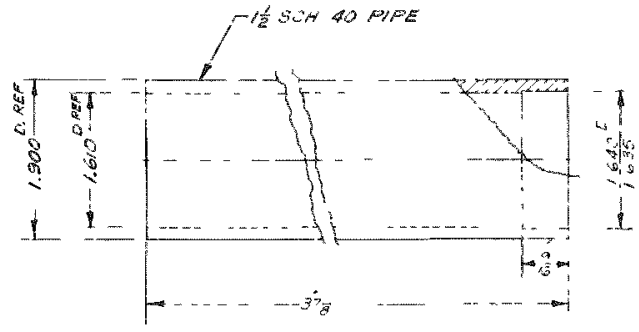

NO. REQUIRED:
TOLERANCES: $\pm \frac{1}{32}$

MATERIAL: 304 SST

SMALL END PIPE

$R E-1-20394-A$
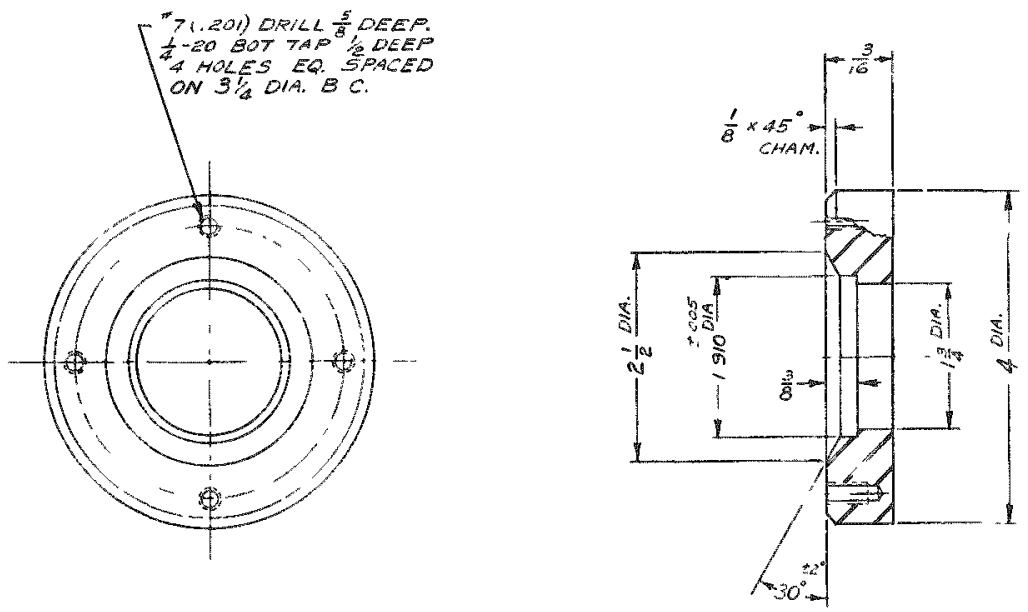

MO. REQUIRED: I

TOLERAMCES: $\pm \frac{1}{32}$ MATERIAL: 405 SST SMALL END FLANGE RE-1-20395-B 


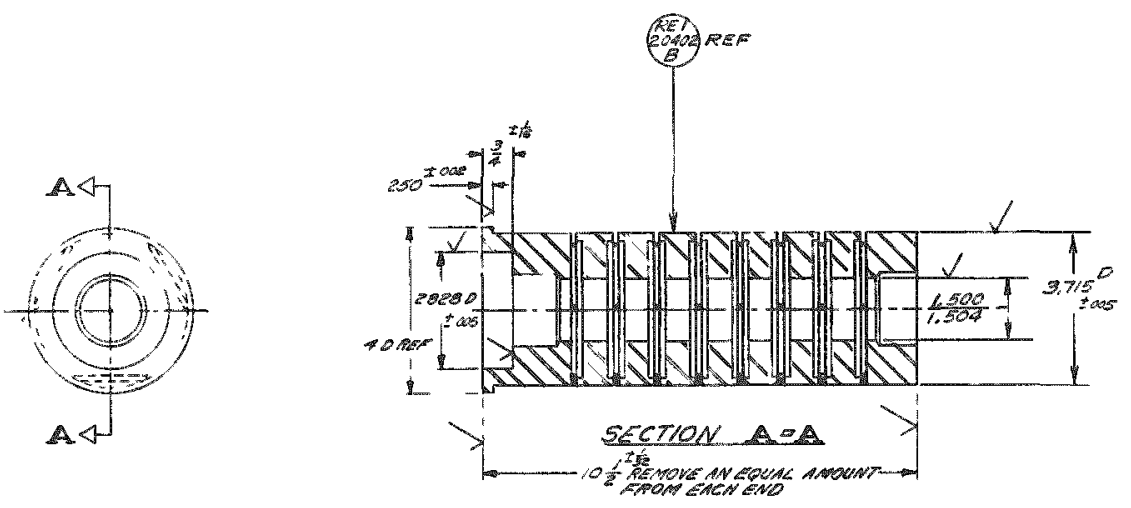

NO. REQUIRED: I

HOLDER

RE-1-20399-B

(2)
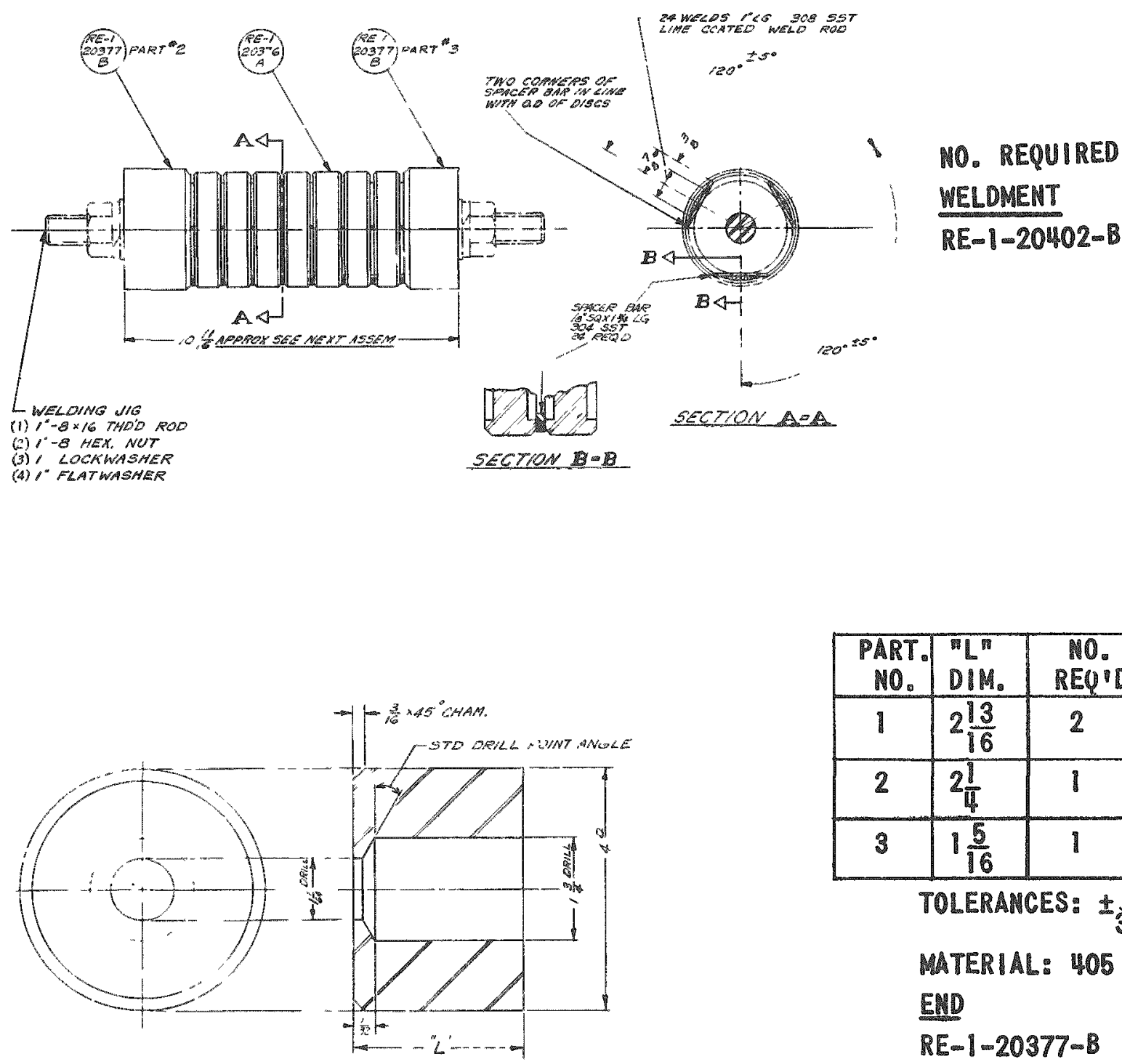

\begin{tabular}{|c|c|c|}
\hline $\begin{array}{c}\text { PART. } \\
\text { NO. }\end{array}$ & $\begin{array}{c}\text { "LIM. } \\
\text { DIM. }\end{array}$ & $\begin{array}{c}\text { REQ } \\
\text { RED }\end{array}$ \\
\hline 1 & $2 \frac{13}{16}$ & 2 \\
\hline 2 & $2 \frac{1}{4}$ & 1 \\
\hline 3 & $1 \frac{5}{16}$ & 1 \\
\hline
\end{tabular}

MATERIAL: 405 SST

END

$R E-1-20377-8$ 


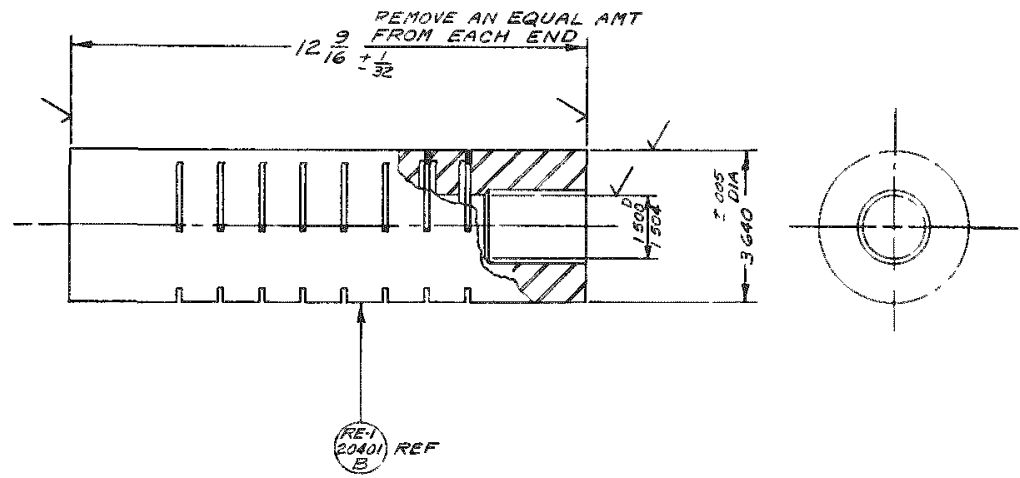

NO. REQUIRED: I

ARMATURE

$R E-1=20400-8$

(3)

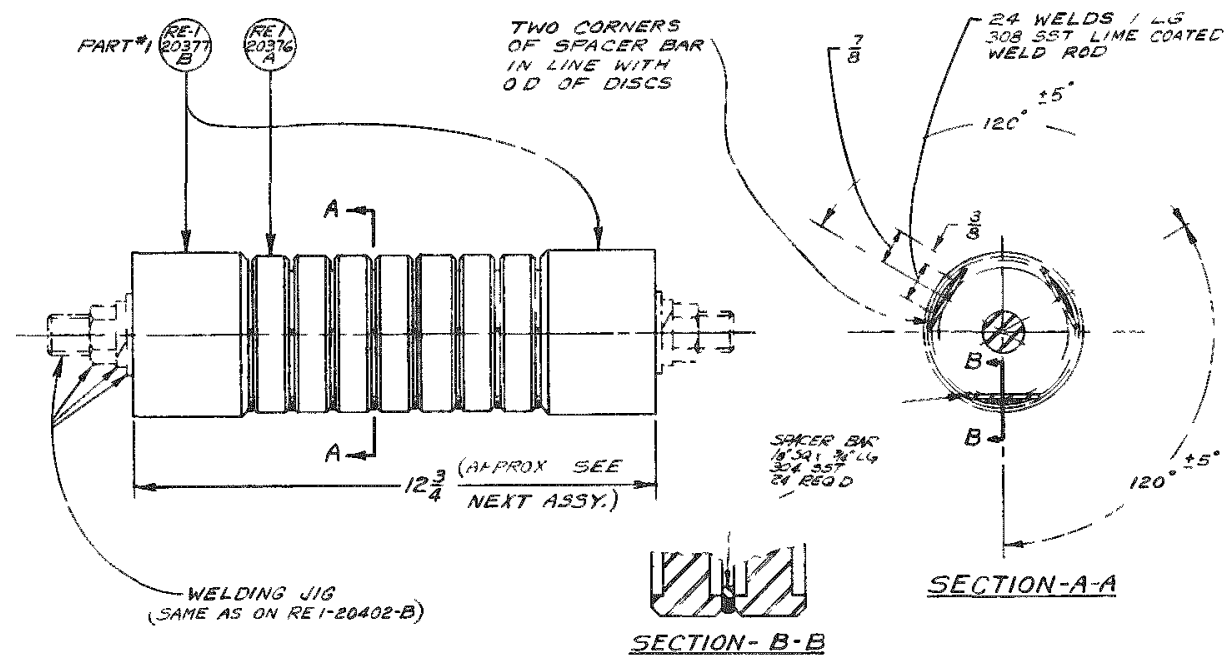

MO. REQUIRED: I

WELDMENT

$R E-1-2040 \mid=B$

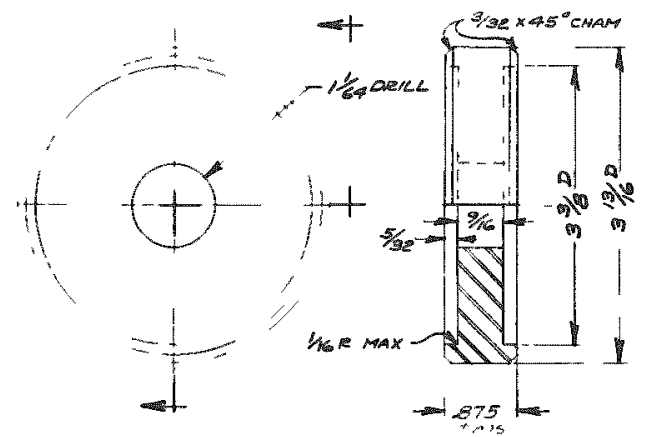

NO. REQUIRED: 14

TOLERANCES: $\pm \frac{1}{32}$

MATERIAL: 405 SST

DISC

RE- I-20376 A 

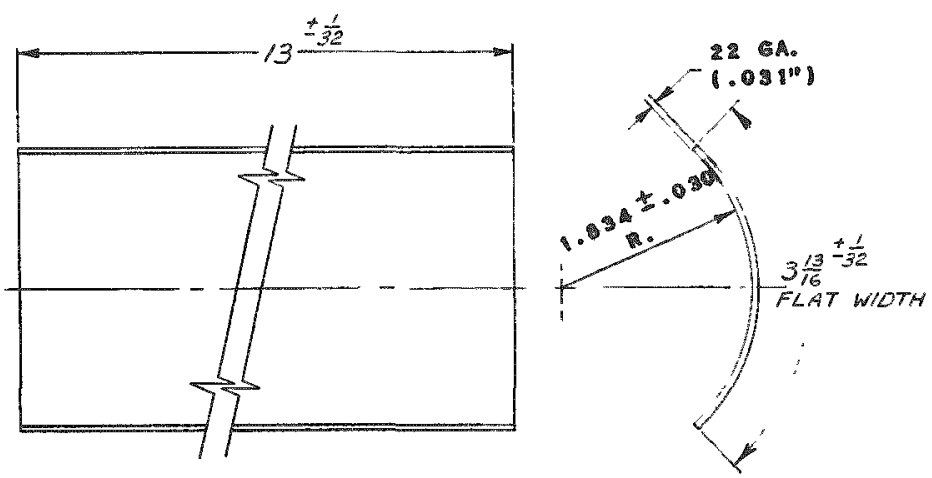

NO. REQUIRED: 3 MATERIAL: 304 SST NON-MAG. SLEEVE BE-1-20381-A

(4)
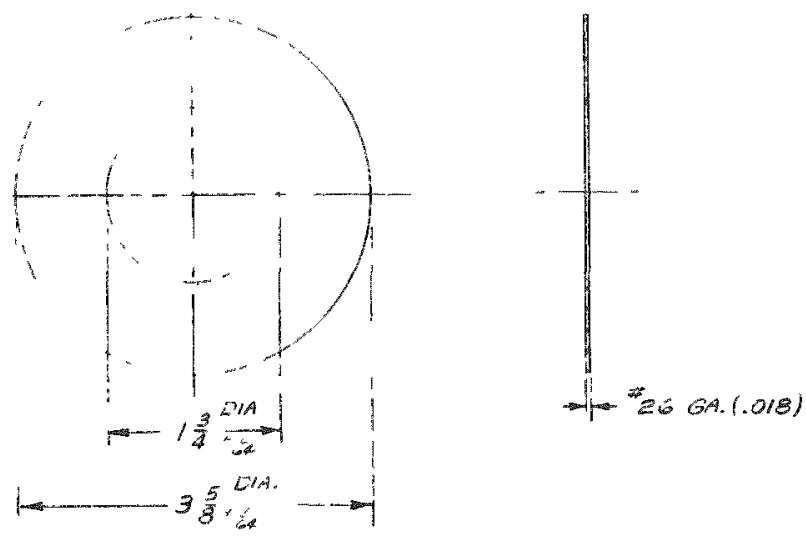

NO. REQUIRED: 2 MATERIAL: 304 SST MON-MAG. WASHER $R E-1=20380-A$

(5)

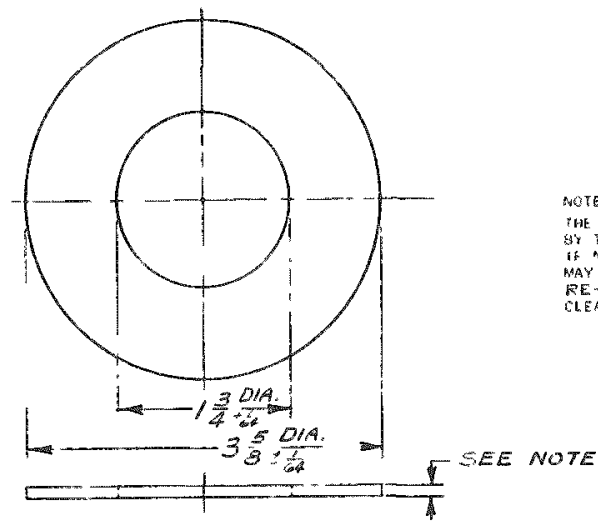

NO. REQUIRED: I MATERIAL: 405 SST

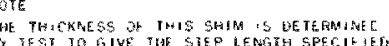

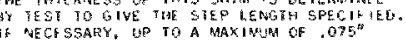

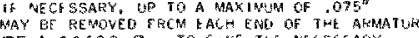
RE $-1-20400$

SHIM

$R E=1-20379-A$

(6)
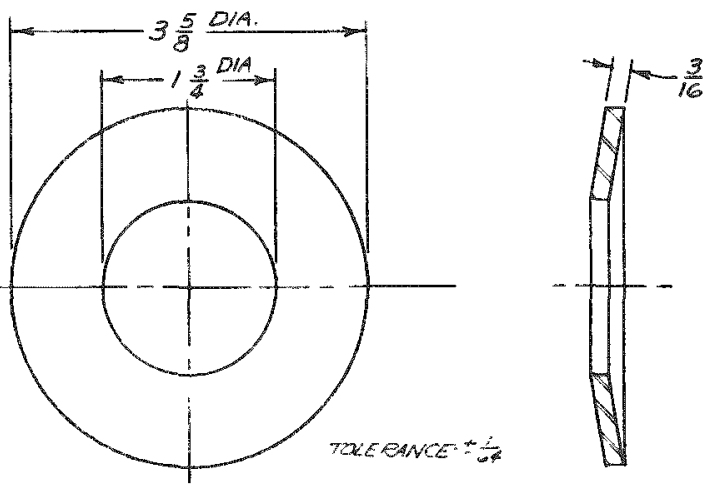

NO. REQUIRED: 2 TOLERANCES: $\pm \frac{1}{64}$ MATERIAL: 405 SST CUSHION WASHER $R E-1=20378-A$ 


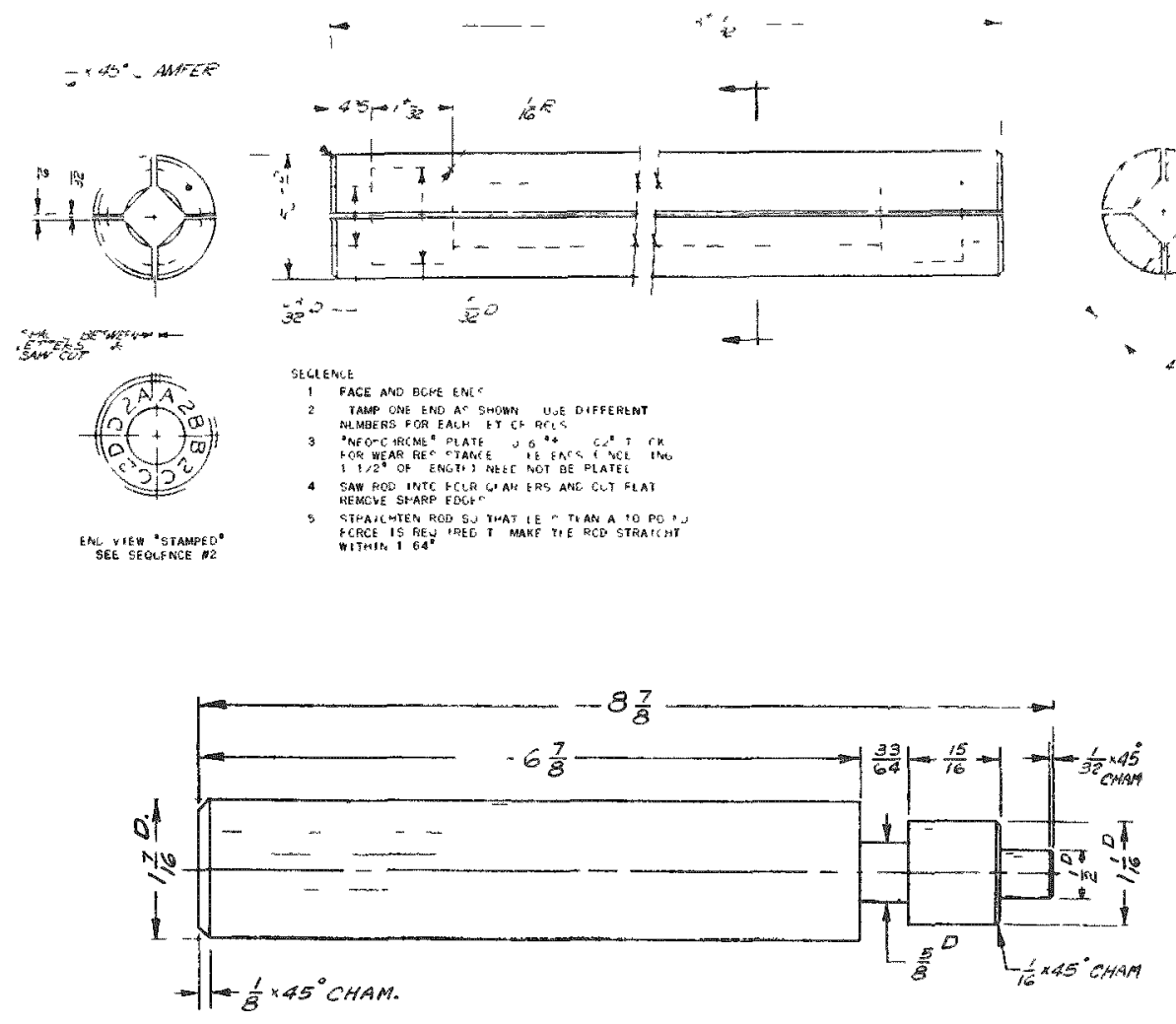

NO. REQUIRED: I

TOLERANCES:

FRACTI ONAL $\pm \frac{1}{64}$

DECIMAL \pm .005

MATERIAL: SST

ARMCO 17-4-PH

DRIVE ROD

$\overline{R E-1-20177-B}$

(8)

NO. REQUIRED: I

TOLERANCES:

FRACTIONAL $\pm \frac{1}{64}$ DECIMAL \pm .005

MATERIAL: SST ARMCO 17-4 PH

P. I. ROD

$R E=1-20383=A$

(9)

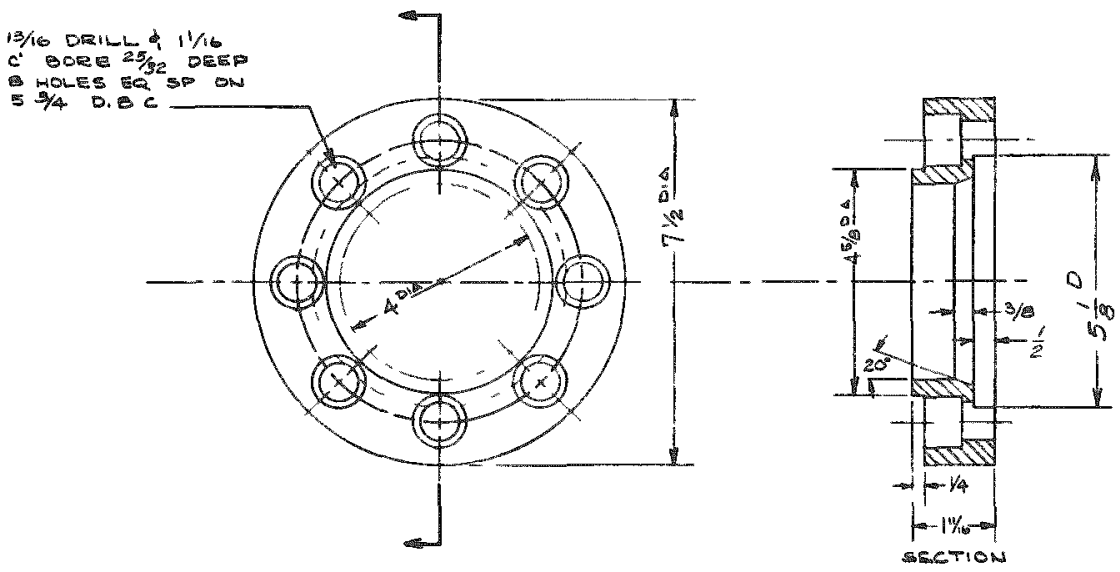

NO. REOUIREO: I TOLERANCES: $\pm \frac{1}{32}$

MATERIAL:

MILD STEEL

FLANGE RING

RE-1-20382-B

(12)

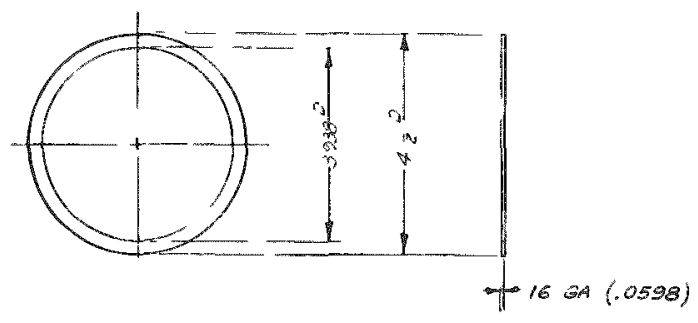

NO. REQUIRED: 16

TOLERAMCES: $\pm \frac{1}{32}$

MATERIAL:

MILD STEEL

COIL SPACER

$R E=1-20388-A$

(16) 


\section{Rod Connection}

The assembly and detail drawings of the device which connects the control rod to the drive rod of the magnetic jack are listed on page 60 In addition to the connection parts, this device has a stack of Belleville washers which cushion the rod assembly after it is dropped for scramming. The washers also serve as a heat barrier and radiation shield.

The procedure for installing and removing the drive without re moving the control rod or the vessel cover is shown on pages 59 and 60 There are no close fitting parts and no screw threads.

Since the crane hook rises only $7 \mathrm{ft}$ above the floor, a lift beam is used with the crane to lift the jack high enough to go over the drive rod. The end of the beam is clamped on the pipe just below the position indicator coils. The crane hook lifts the beam close to the load. The free end of the beam is held down by hand to make the jack hang vertically. 


\section{ASSEMBLY PROCEDURE FOR JACK \#27 CONNECTION}

1. Lower the extension rod ( $1 \frac{1}{4} \mathrm{in}$. dia by $112 \mathrm{in.}$ long) into the vessel and onto the control rod ball tip. Push the extension rod down lightly to engage the rod. The connection should snap together when the top end of the extension rod is 4 in. above the flange face.

2. Insert the outer tube ( $6 \mathrm{in.}$ dia. by $3 \pm \mathrm{in}$. long) in the vessel thimble.

3. Drop the $5 \frac{3}{16}$ in. OD Belleville springs into the outer tube, making sure that each spring faces in the opposite direction from the one next to it. Stack them to within $9 \frac{1}{4}$ in. and $9 \frac{1}{2}$ in. below the top of the outer tube (about 97 springs).

4. Drop the $5 \mathrm{in}$. OD Belleville springs on top of the larger springs in the same manner. Stack them to within $6 \frac{1}{4}$ in. and $6 \frac{1}{2}$ in. below the top of the outer tube (about 12 springs).

5. Insert the lock tube ( $1 \frac{1}{2} \mathrm{in.}$ dia by $75 \mathrm{in}$. long), small bore end up, in the spring seat tube ( $2 \mathrm{in.}$ dia by $65 \mathrm{in.}$ long), flanged end up, and hook the lift tool into the groove.

6. Lower the spring seat tube into the stack of springs until the flange rests on the springs.

7. Raise the extension rod about $\frac{1}{8}$ in. to allow the connector to close and the lock tube to seat.

8. Raise the extension rod 3 to $6 \mathrm{in}$. to see that the control rod is connected, then lower it gently to the bottom again.

9. Lower the drive rods $\left(1 \times \frac{1}{2} \times 53 \mathrm{in.}\right)$ into the space around the extension rod. Have the stamped end of the rods at the top and arrange the rods so that the letters correspond and each rod has the same number.

10. Lower the filler tube ( $2 \mathrm{in.}$ dia by $34 \mathrm{in.}$ long) over the drive rods until the flange rests on the spring seat tube.

11. Raise the spring seat tube 6 to $7 \mathrm{in.}$ with the lift tool.

12. Place the two spacers $\left(2 \frac{1}{2} \times 1 \times 6\right.$ in.) under the flange of the spring seat tube and lower the tube onto the spacers. Remove the lift tool.

13. Place the spacer retaine $\left(3 \mathrm{in.}\right.$ dia by $6 \frac{1}{2} \mathrm{in.}$ long) over the flange and spacers.

14. Place two $5 \frac{3}{16} \mathrm{in}$. OD Belleville springs concave side up on the spacer retainer.

15. Place two $5 \frac{3}{16}$ in. OD Belleville springs concave side down on the other two springs.

16. Raise the filler tube about $2 \mathrm{in}$. and slip the support washer ( $6 \mathrm{in}$. dia by $\frac{1}{16}$ in. thick) into the slots near the top of the filler tule. Then drop the tube.

17. Place the back-up ring ( $2 \frac{1}{2} "$ dia by $\frac{1}{4}$ in. long) on the support washer.

18. Insert the position indicator $\operatorname{rod}\left(1 \frac{1}{2} \mathrm{in}\right.$. dia by $9 \mathrm{in}$. long) in the top end of the drive rod.

19. Place the gasket in the groove of the thimble flange.

20. Lowex the magnetic jack over the rod. See that the support washer fits up into the adapter flange of the jack and the four springs fit down into the outer tube.

21. Bolt the adapter flange down to the thimble flange. There should be no gap between the flanges. 


\section{REMOVAL PROCEDURE FOR JACK \#27 CONNECTION}

1. Remove the bolts that fasten the adapter flange to the thimble flange.

2. Hoist the magnetic jack at least 33 in. straight up; then remove.

3. Remove the position indicator rod, the gasket and the back-up ring.

4. Remove the support washer and let the filler tube drop onto the spring seat tube.

5. Remove the four $5 \frac{3}{16}$ in. OD Belleville springs.

6. Remove the spacer retainer.

7. Raise the spring seat tube $\frac{1}{2}$ to $1 \mathrm{in}$. with the lift tool. Then remove the two spacers and lower the spring seat tube slowly onto the stack of Belleville springs. Remove the lift tool.

8. Remove the filler tube.

9. Remove the four drive rod quarters by moving the lower ends outward, then lifting. Use drive rod tool if necessary (48" aluminum bar).

10. Use the lift tool to lift the spring seat tube out with the lock tube in it.

11. Remove most of the Belleville springs to reduce the weight; then remove the outer tube.

12. Lift the extension rod 3 to 6 in. to see that the control rod is disconnected. If the control does not remain at the bottom, hold it there with an $8-\mathrm{ft}$ rod or tube while lifting the extension rod.

\section{PARTS LIST FOR JACK \#27 CONNECTION}

Number

Required

Per Unit

\begin{tabular}{rr}
1 & \\
1 & \\
1 & \\
1 & \\
14 & \\
102 & \\
1 & \\
2 & \\
1 & \\
1 & \\
1 & \\
& 1 \\
& 1 \\
1 & \\
& 1 \\
& 1 \\
& 1 \\
& 1 \\
\hline 1 &
\end{tabular}

Page

62

62

63

63

63

63

64

64

64

64

65

65

65

66

66

66

66

66

62

\begin{tabular}{l} 
Part Name \\
\hline Adapter Flange \\
Spring Seat Tube \\
Filler Tube \\
Lock Tube \\
5 in. dia Belleville Spring \\
$5 \frac{3}{16}$ in. dia Belleville Spring \\
Support Washer \\
Spacer \\
Spacer Retainer \\
Back-up Ring \\
Outer Tube Assembly \\
Body \\
End \\
Dxtension Rod Assembly \\
Drive End \\
Tube \\
Upd End
\end{tabular}

Lift Tool

Gasket, Flexitallic \#R4-4N

\section{Drawing Number}

RE- $1-22615-\mathrm{B}$
$6-\mathrm{B}$
$7-\mathrm{B}$
$8-\mathrm{B}$
$9-\mathrm{A}-\mathrm{Part} \# 1$
$9-\mathrm{A}-\mathrm{Part}$ \#2
$20-\mathrm{A}$
$1-\mathrm{A}$
$2-\mathrm{A}$
$3-\mathrm{A}$
$4-\mathrm{B}$
$5-\mathrm{B}$
$6-\mathrm{A}$
$7-\mathrm{B}$
$8-\mathrm{A}$
$9-\mathrm{A}$
$30-\mathrm{B}$
RE-1-22769-A
RE-1-24181-B




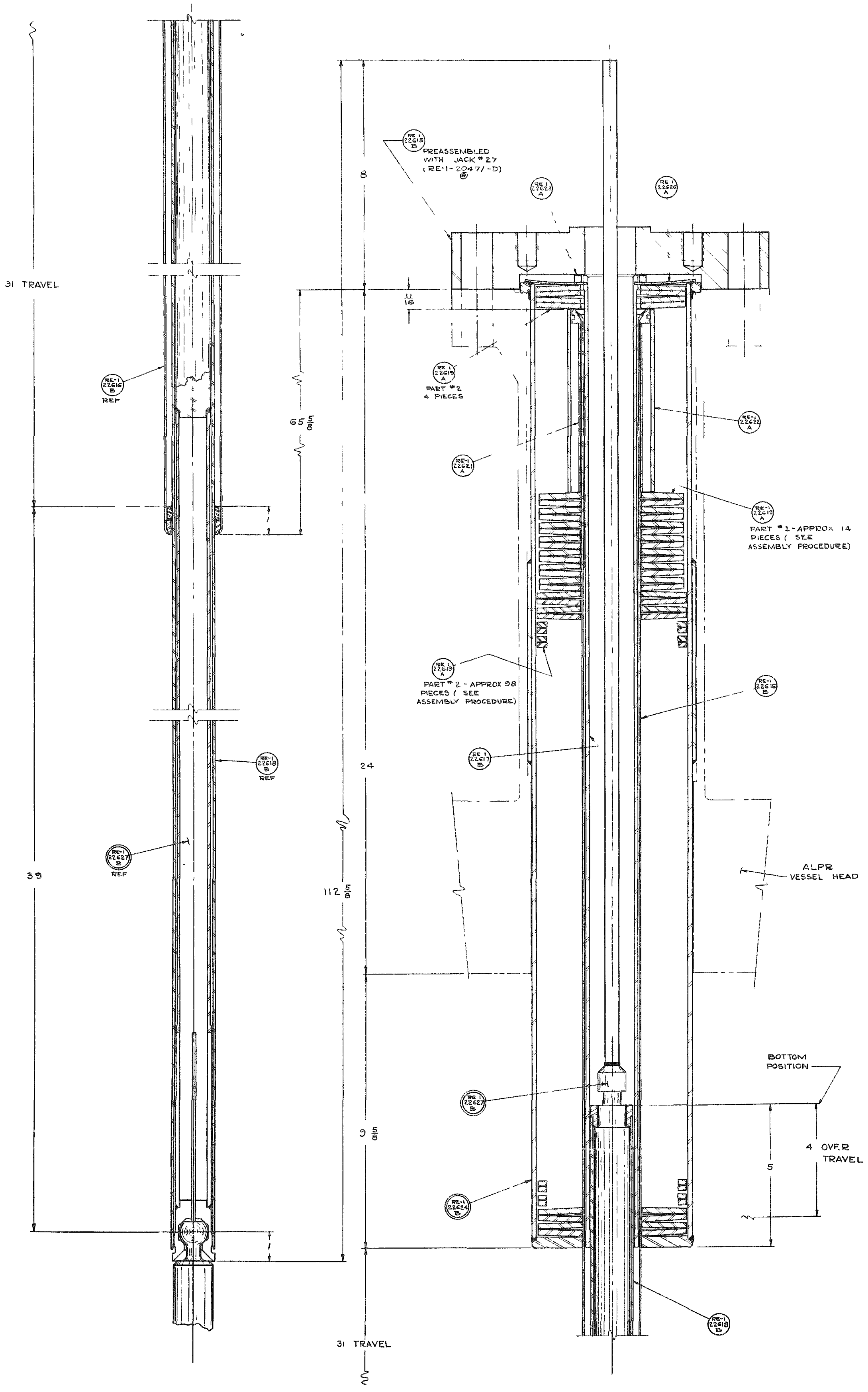

ROD CONNECTION ASSEMBLY 

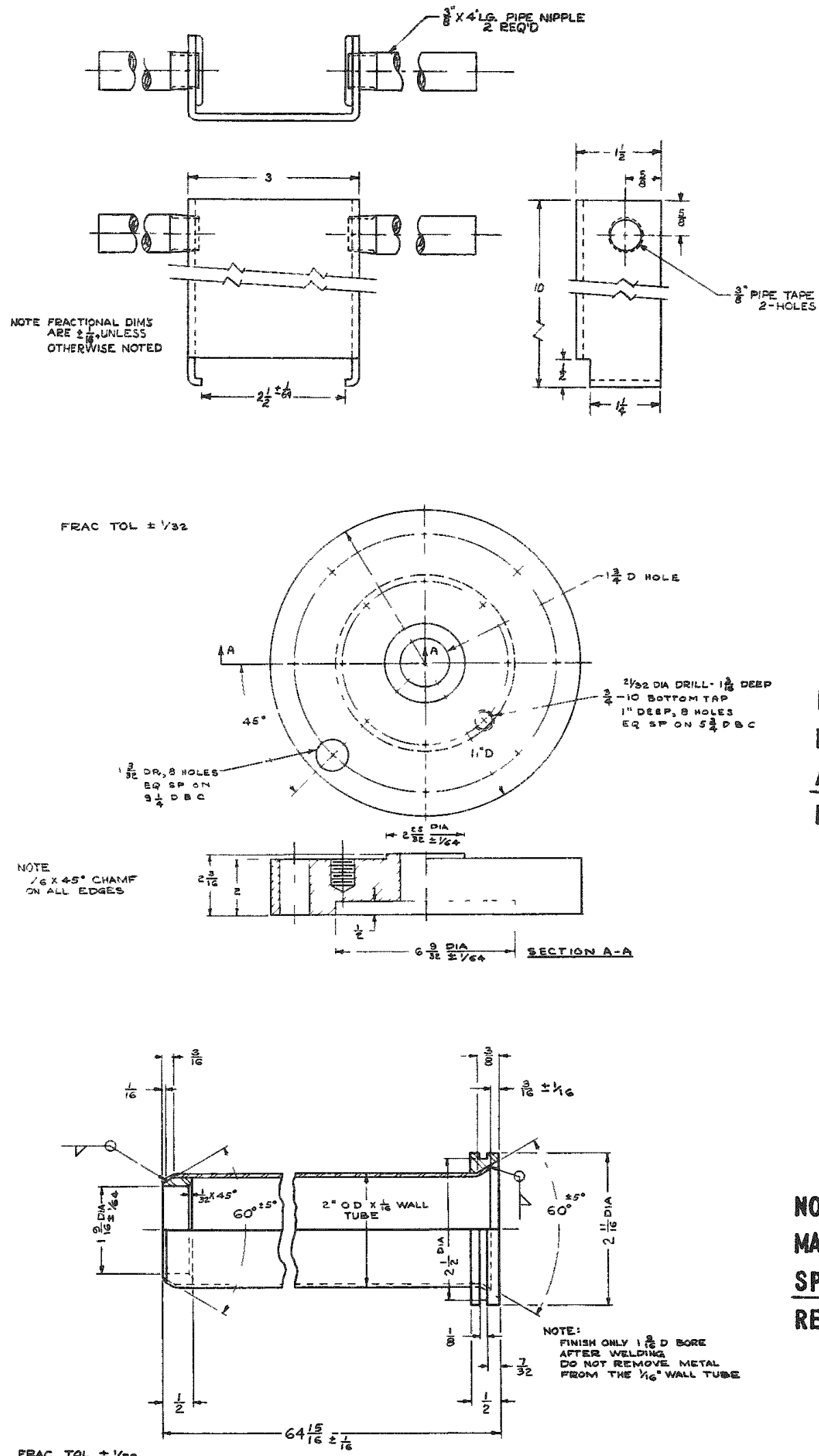

FAAC. TOL $\pm 1 / 32$
MATERIAL:

II GA. (1119)

MILD STEEL

LIFT TOOL

$R E-1-24181-B$

(SEE ASSEMBLY

PROCEDURE)
NO. REQ 'D.: I

MATERIAL: 405 SST

ADAPTER FLAMGE

RE-1 -22615-B
MO. REQ'D. I

MATERIAL: 304 SST

SPRING SEAT TUBE

RE-1-22616-B 


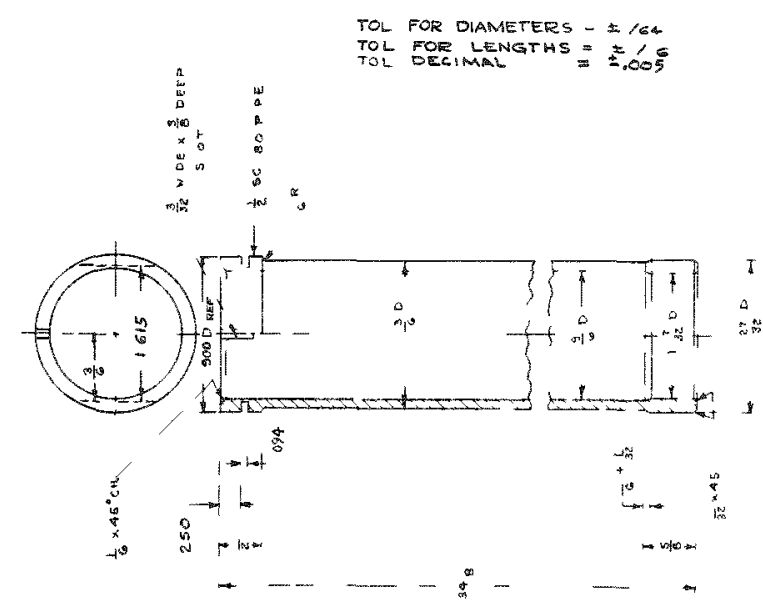

MO. REQ D: I MATERIAL: '304 SST

FILLER TUBE

$R E-1=226 i 7-B$
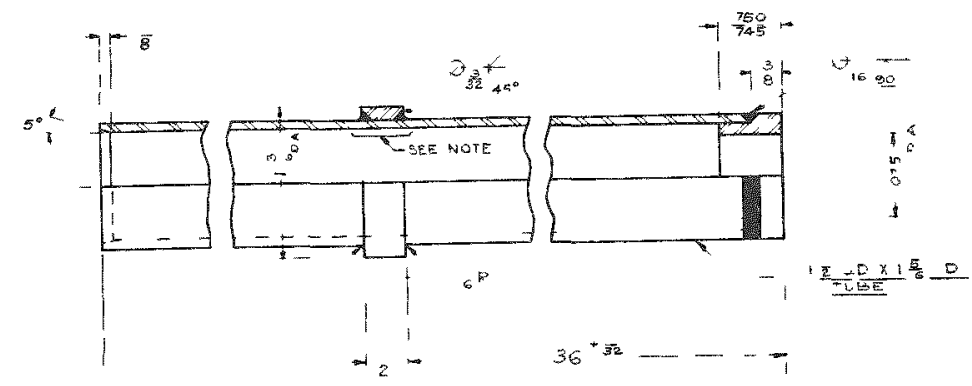

NO. REQPD.: I

TOLERAHCES:

FRACTIONAL $\pm \frac{1}{64}$ DECIMAL \pm .005

MATERIAL: 304 SST

LOCK TUBE

- $-1 \quad-7 \frac{5}{8}=-\frac{-1}{6}$

RE $-1-22618=6$

NOTE REAM TO I 92 DIA

F MECESSARY AFTER

WELING

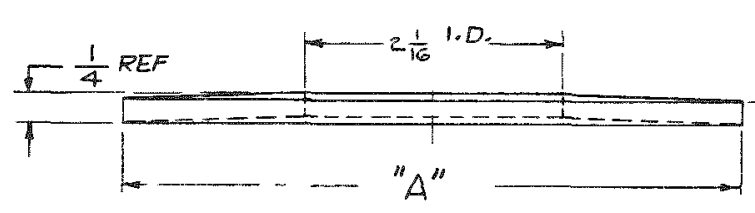

TO GIVE DESIRED SPRING

BACK, PRESS WITH $10^{\circ}$ DIE

THEN P ESS WITH FLAT DIE

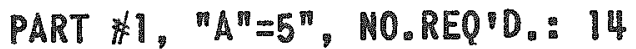

PART \#2, " ${ }^{n}=5 \frac{3}{16} "$, MO.REQ D.: 102

$E_{\frac{3}{16}}$ 中 TOLERANCES: $\frac{1}{64}$

MATERIAL: 17.4 PH SST

BELLEVILLE SPRING

RE-1-22619-A 


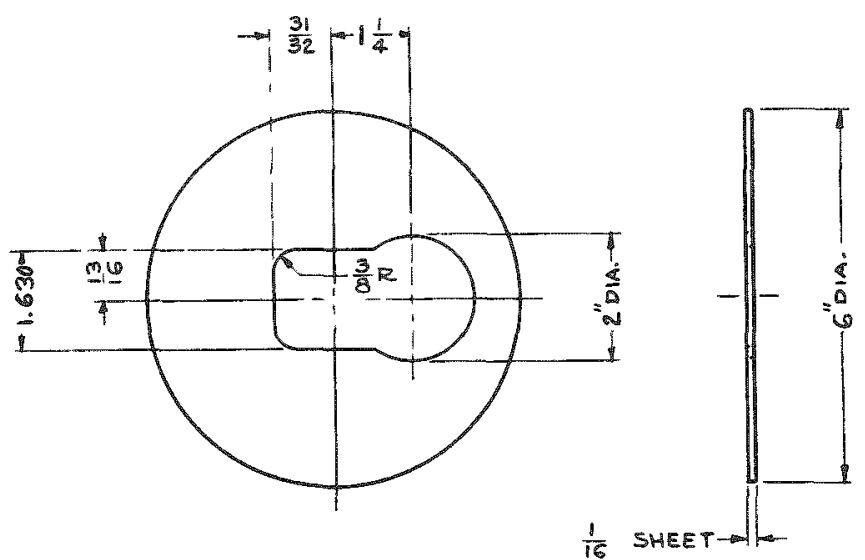

FEACTIONAL TOL $=1 / 32$

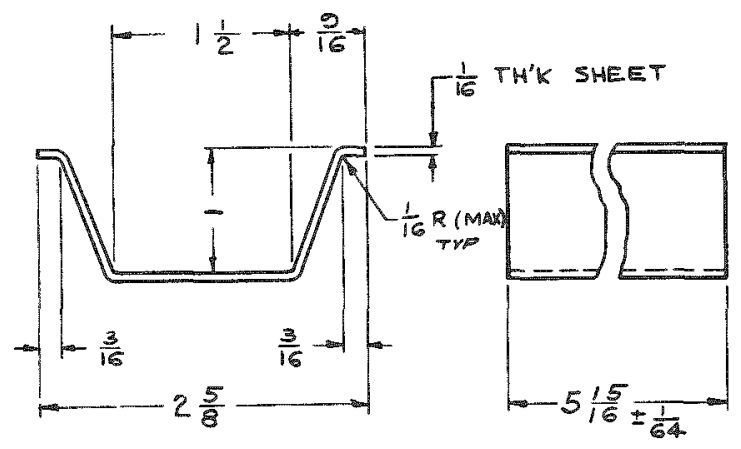

FRAC TOL $=1 / 32$
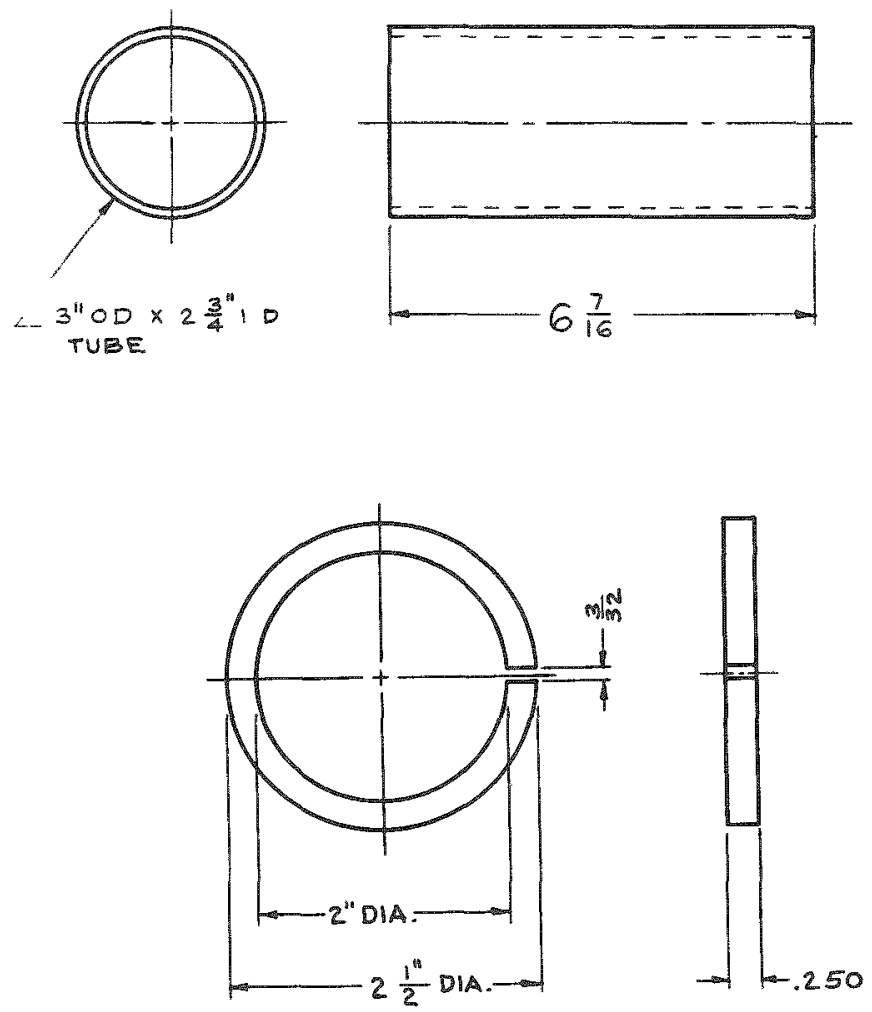

NO. REQ D.: I

MATERIAL: 304 SST SUPPORT WASHER RE-1-22620-A
HO. REQ'D.: 2

MATERIAL: 304 SST SPACER

RE-1-22621 -A
NO. REQD.: I TOLERAMCES: $\pm \frac{1}{64}$ MATERIAL: 304 SST SPACER RETAINER $R E-1-22622-A$
HO. REQDD.: I

TOLERAMCES:

FRACTIONAL $\pm \frac{1}{32}$

DECIMAL \pm .005 MATERIAL: 304 SST

BACROUP RIMG $R E=1-22623=A$ 


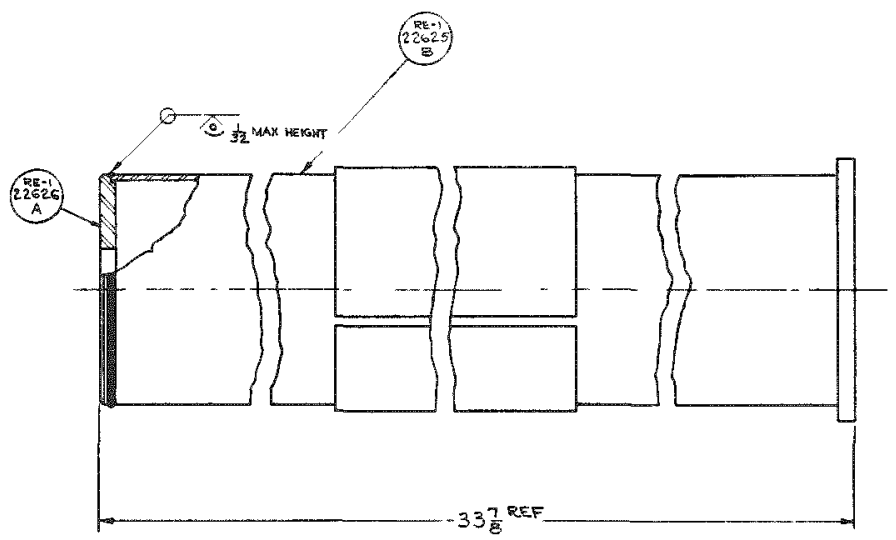

NO. REQ'D:

TOLERANCES: $\pm \frac{1}{64}$

MATERIAL: 304 SST

OUTER TUBE

RE- I-22624-B

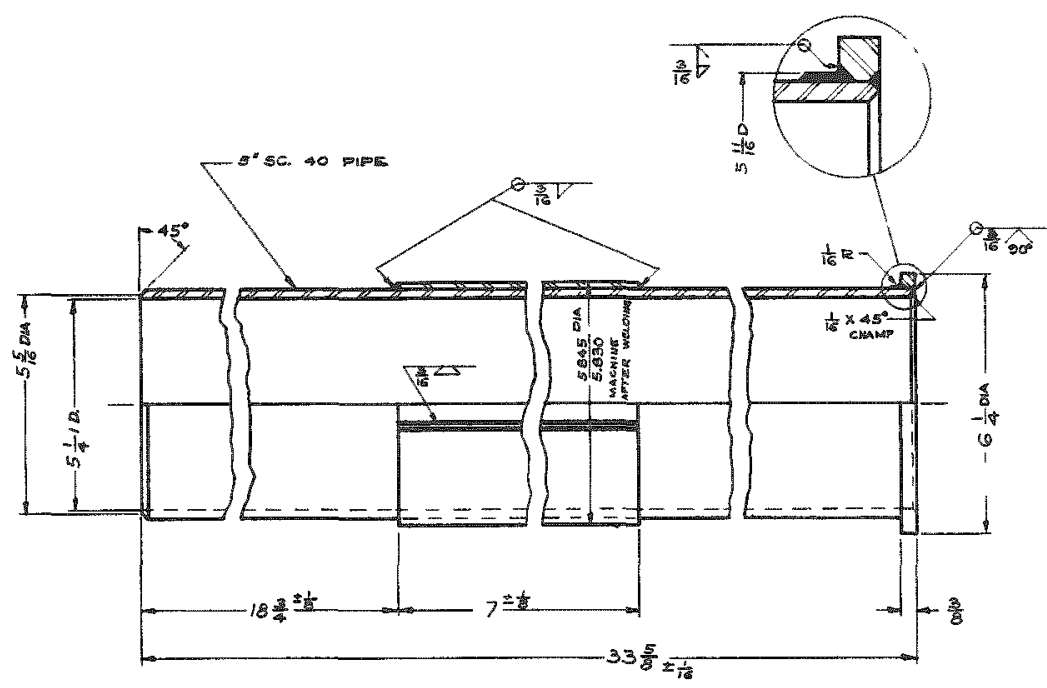

$R E-1=22625-B$

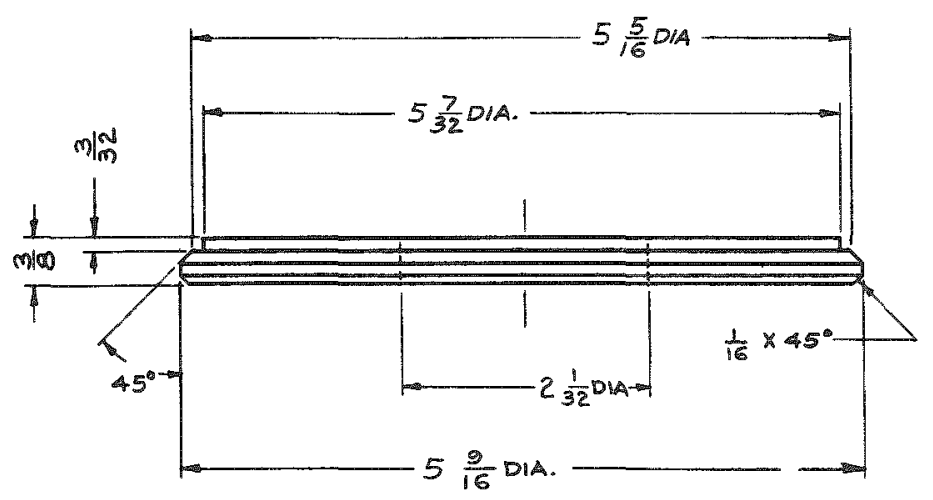




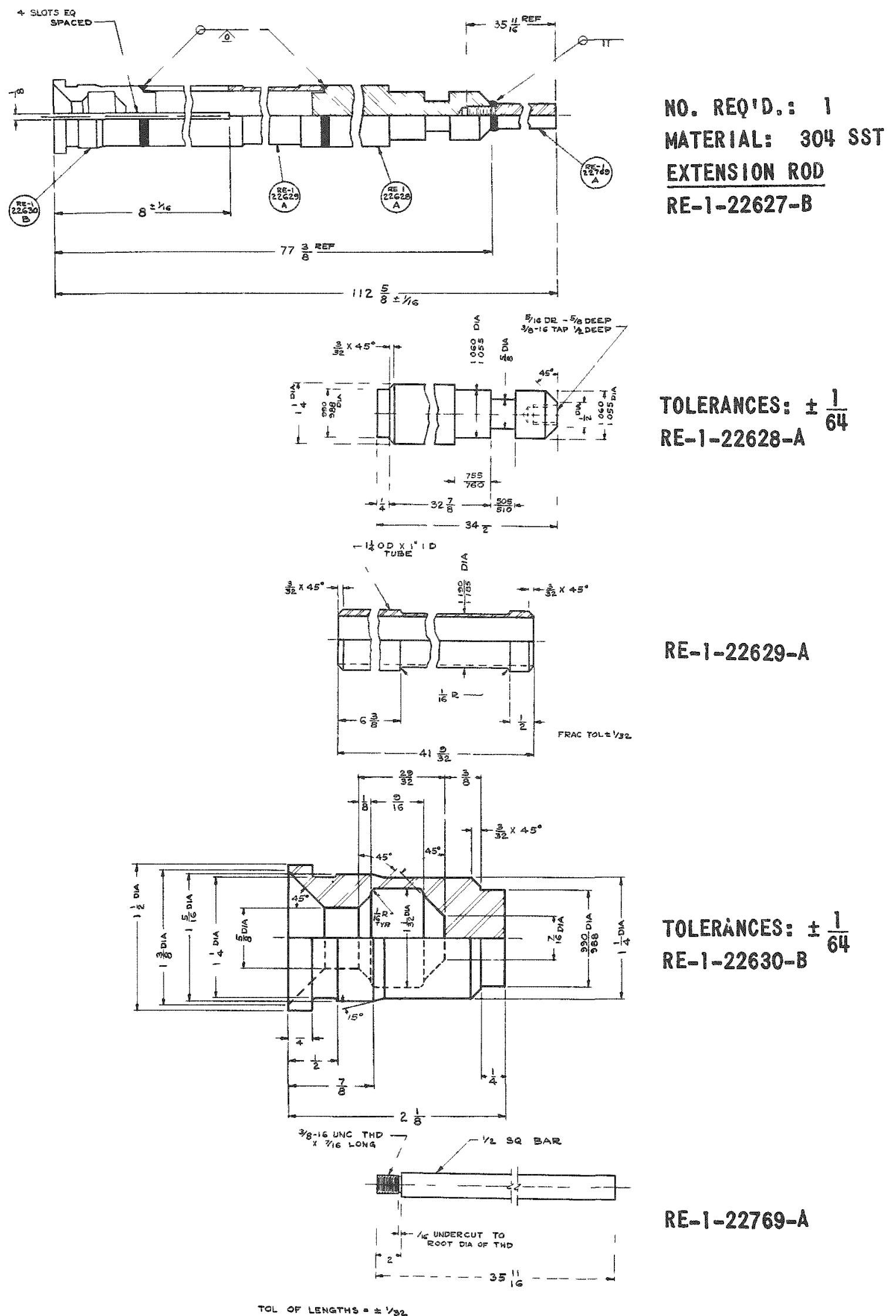


Position Indicator

Approximate position is shown on a long-scale meter which has equally spaced inch marks. Close position is measured by switching a milliammeter to the group of coils in which the end of the drive is located. The position is then read on a corresponding curve which converts milliamps to inches.

To adjust for any variation in line voltage and also to compensate for changes in temperature of the drive, the voltage is adjusted manually so that a meter indicates the voltage which should be used at that temperature.

The center light (amber) located under the position meter indicates that this drive is selected to be operated. This is the same as that used with the rack and pinion drive. The right light (red) indicates that the rod is all the way out and the left light (green) indicates that the rod is all the way in. This function is similar to that used with the rack and pinion drive, but the actuation is by coil and relay instead of by limit switch.

Although the position indicator meter is mounted in a standard cabinet for testing and shipping, the meter may be mounted on the ALPR panel in place of one of the existing position indicators.

The position indicator coil assembly is shown on page 68 . The spaces between the coils are adjusted to make the meter $x$ ead correctly.

In addition to the coils, the position indicator system consists of the following components: Power Supply, page 69; Selector, page 70; Meters and Lights, page 70. 


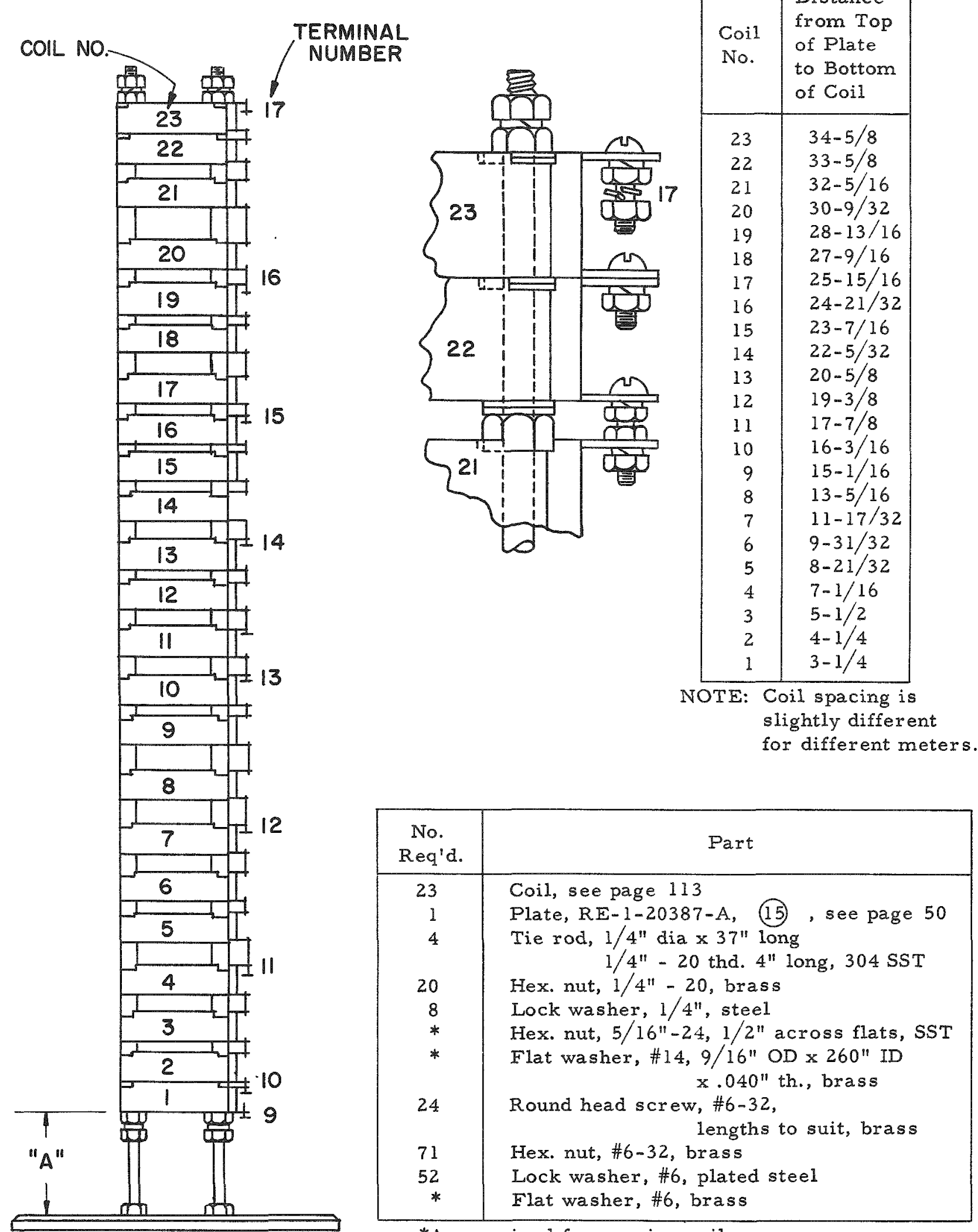

* As required for spacing coils 


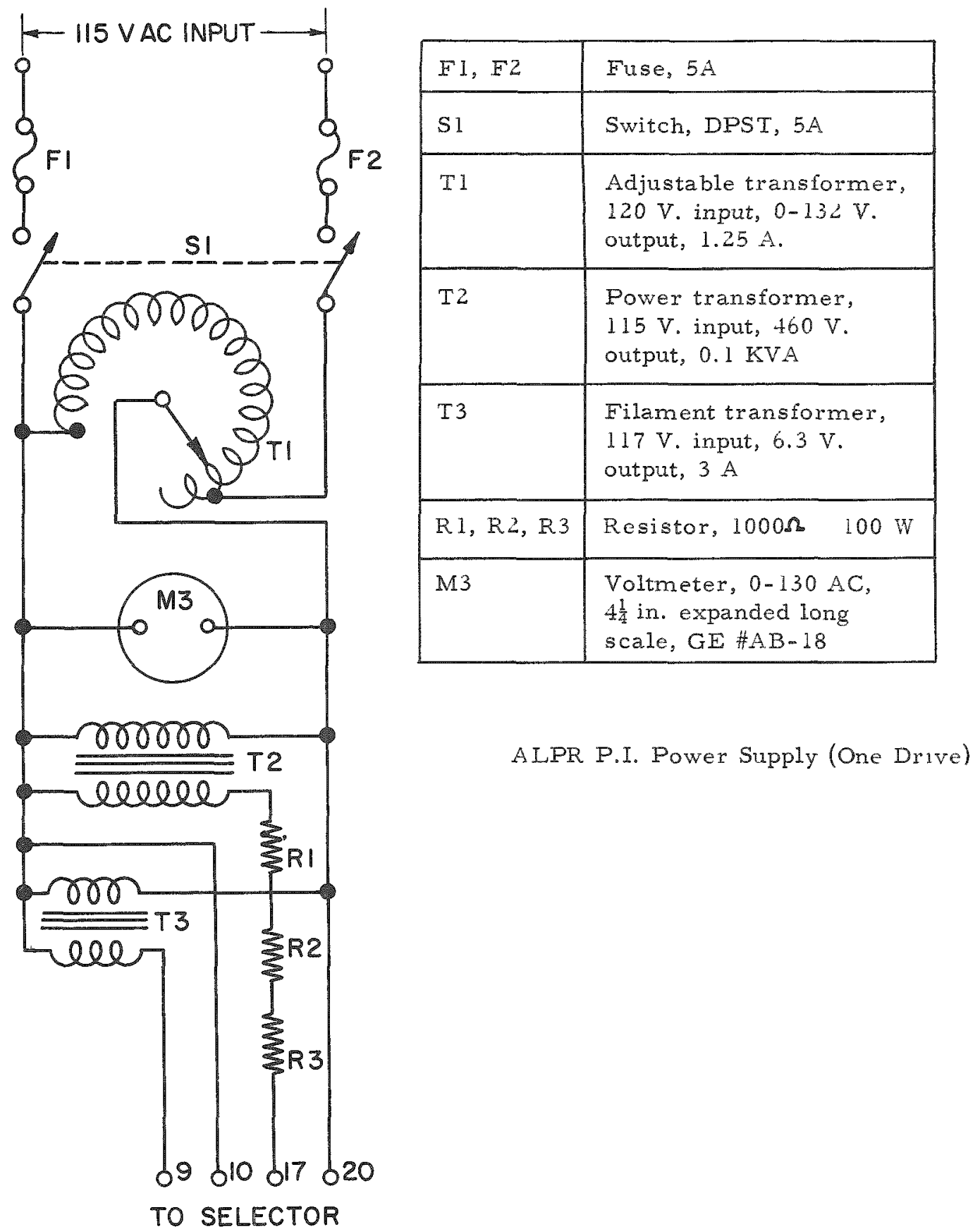




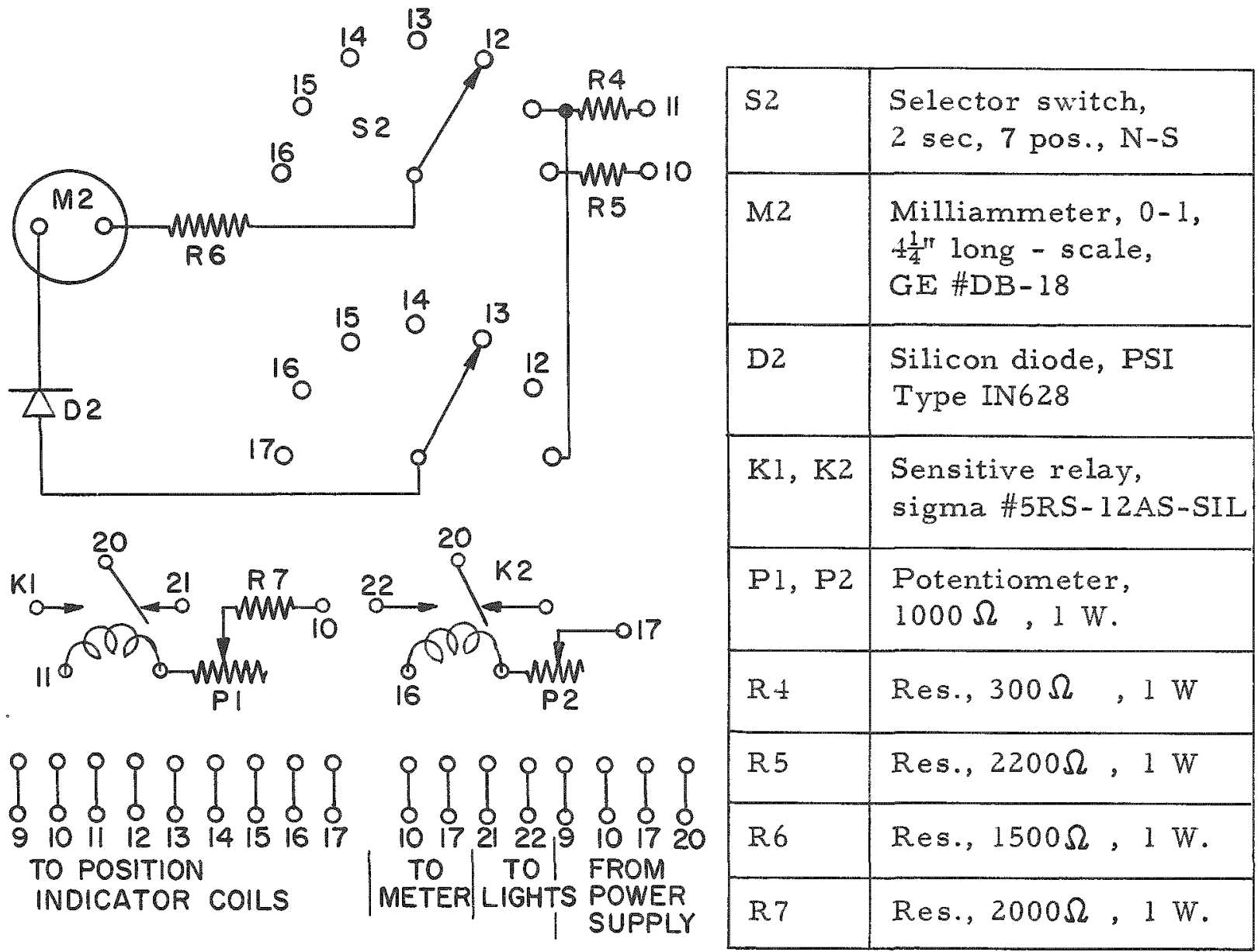

ALPR P.I. Selector (one drive)

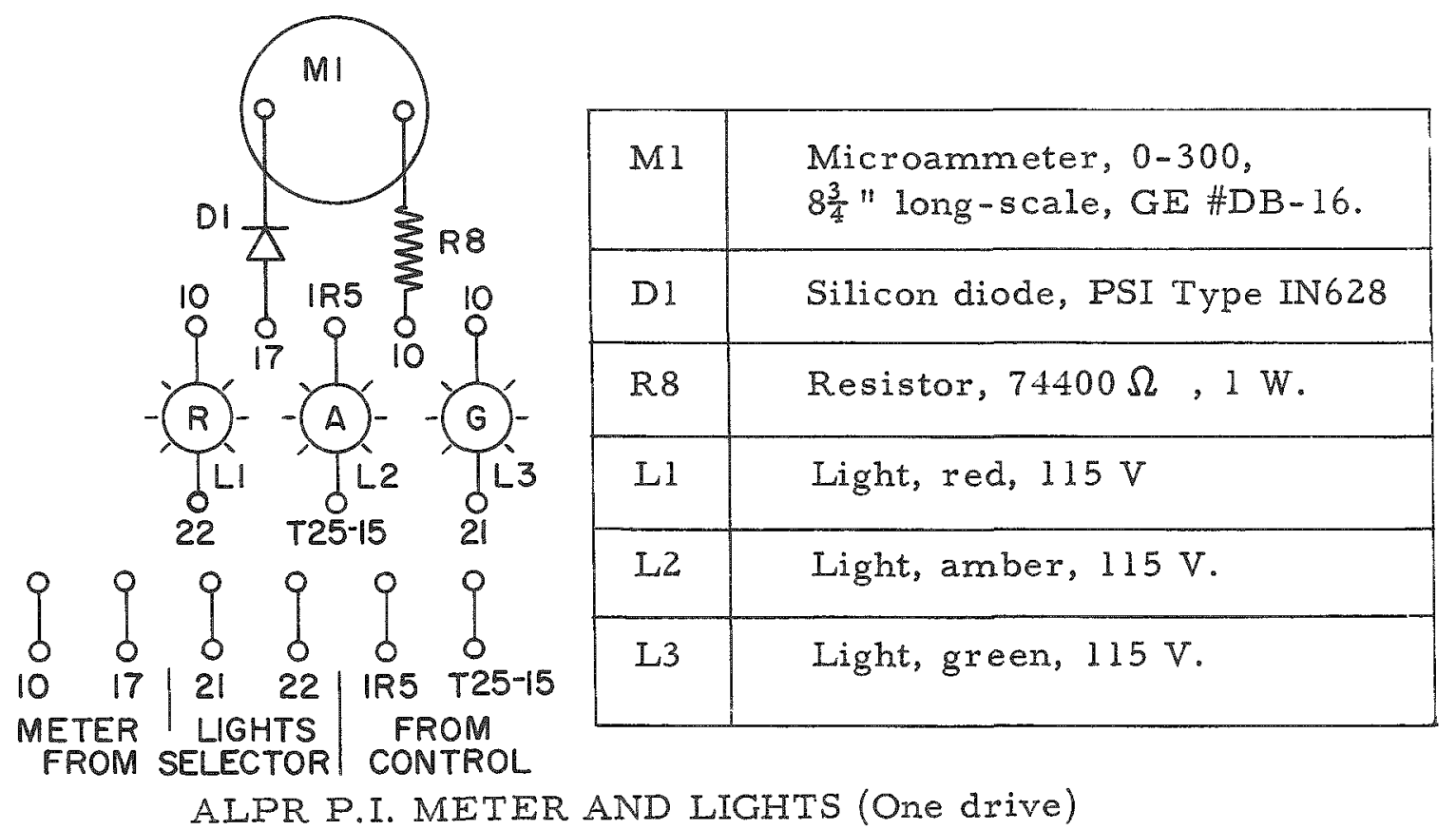


Control

The control shown on page 73 is used for preliminary test operation of the magnetic jack. For actual reactor operation the jack power supply is connected to the reactor control panel.

The jack makes 30 steps per minute. The step length is adjusted to 0.10 inch at assembly to give a speed of 3 inches per minute (see shim drawing RE-1-20379-A, page 56). A switch may be provided on the control panel for switching from the coarse step to a fine step of about 0.006 inch.

\section{Power Supply}

The power supply consists of a commutator switch (page 74) and a rectifier assembly (page 75). The commutator switch should be replaced after about 300 hours of operation (1 year, assuming the control rod is moving $3.4 \%$ of the time).

The magnet coils and the position indicator coils are powered by a high-temperature flexible cable which goes through the rack and pinion drive shaft hole in the shield. The cable has a plug which plugs into the socket that powered the rack and pinion drive. 


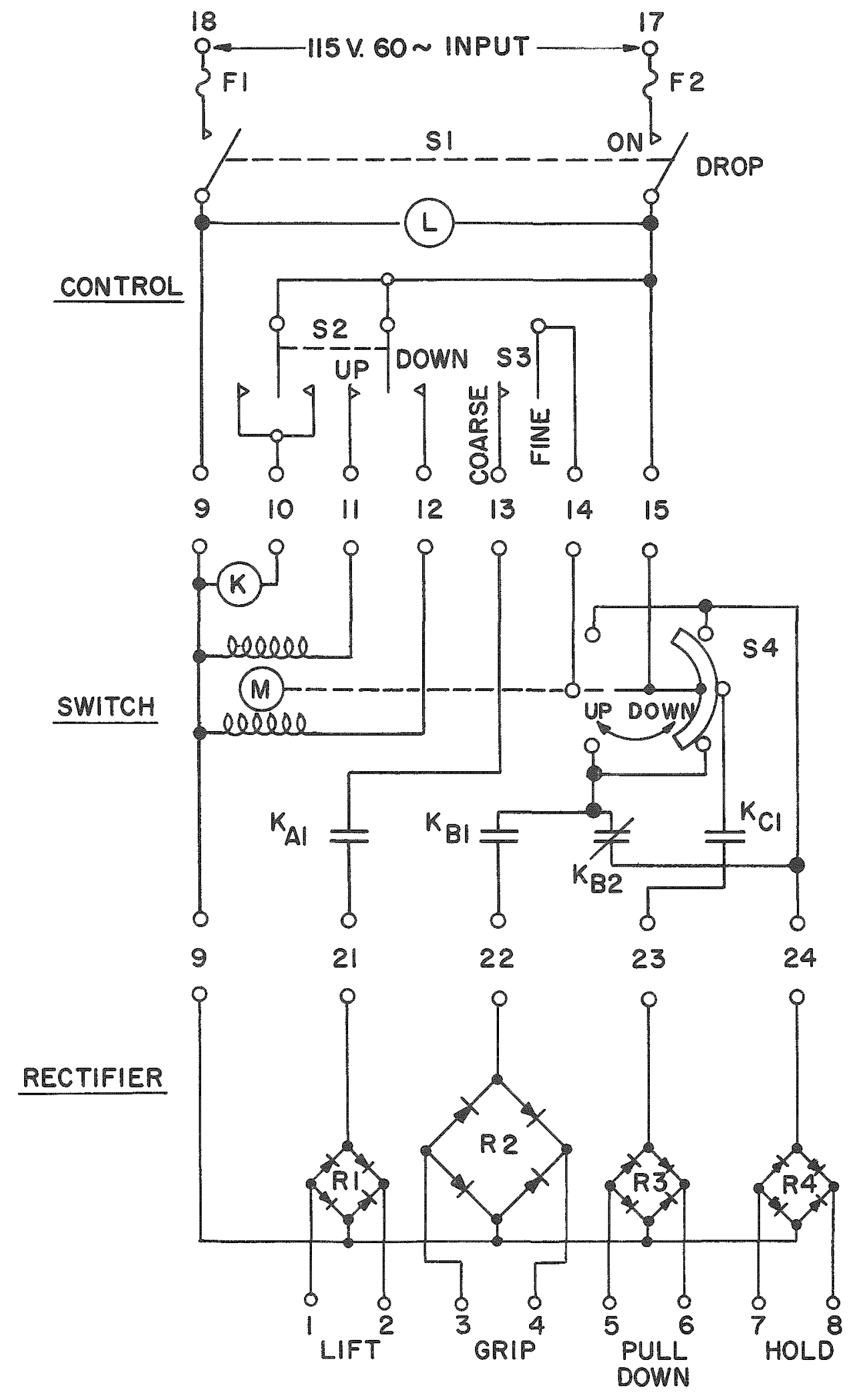

POWER SUPPLY FOR ONE MAGNETIC JACK 


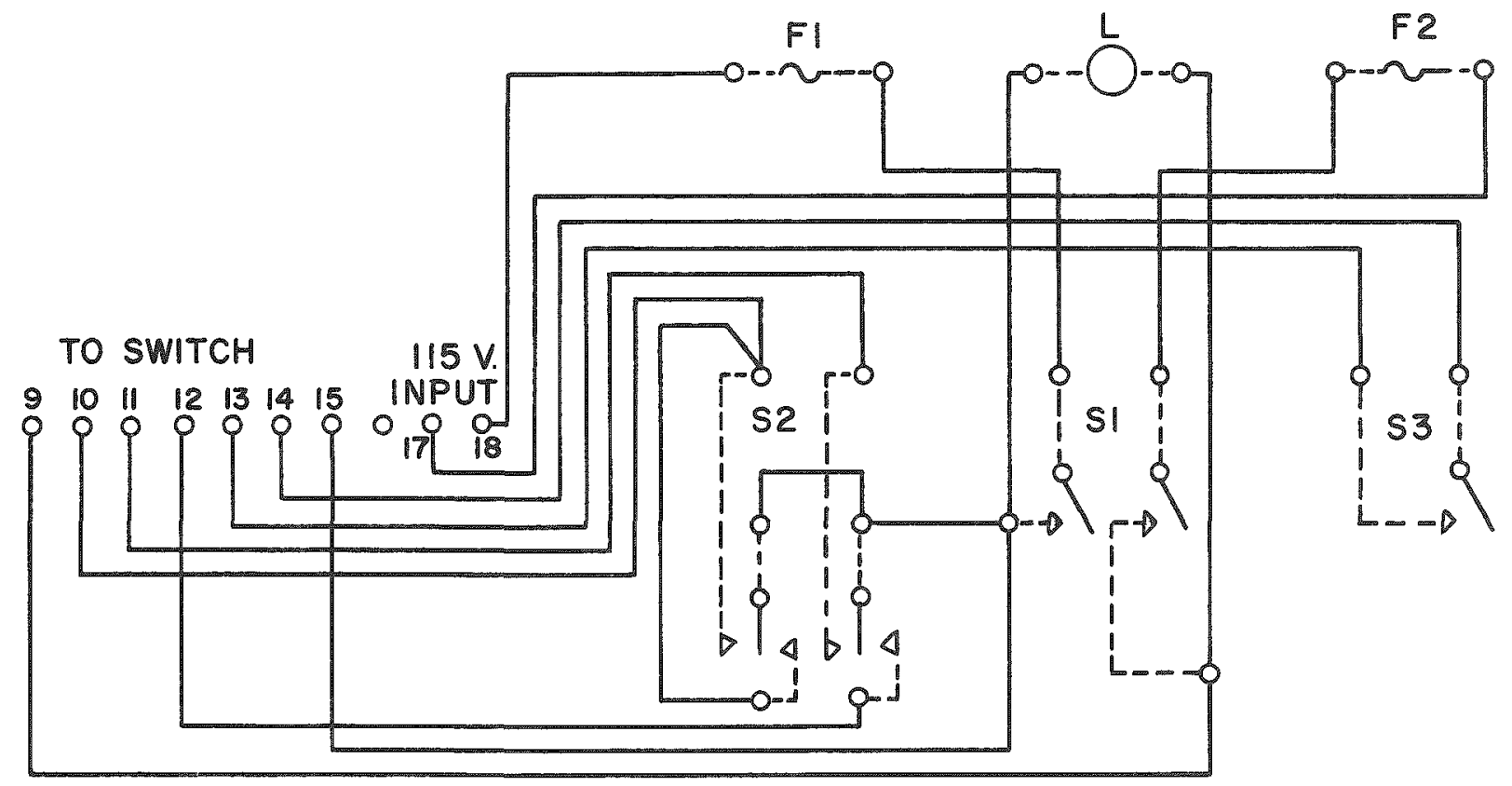

\begin{tabular}{|l|l|}
\hline S1 & Switch, DPST, 15 A \\
\hline S2 & Switch, DP3T, spring return to center off, 5A \\
\hline S3 & Switch, SPST, $10 \mathrm{~A}$ \\
\hline E1, F2 & Fuse, 30 A \\
\hline L & Indicating light, $115 \mathrm{~V}$. \\
\hline
\end{tabular}

CONTROL (for one rod)

Back View 


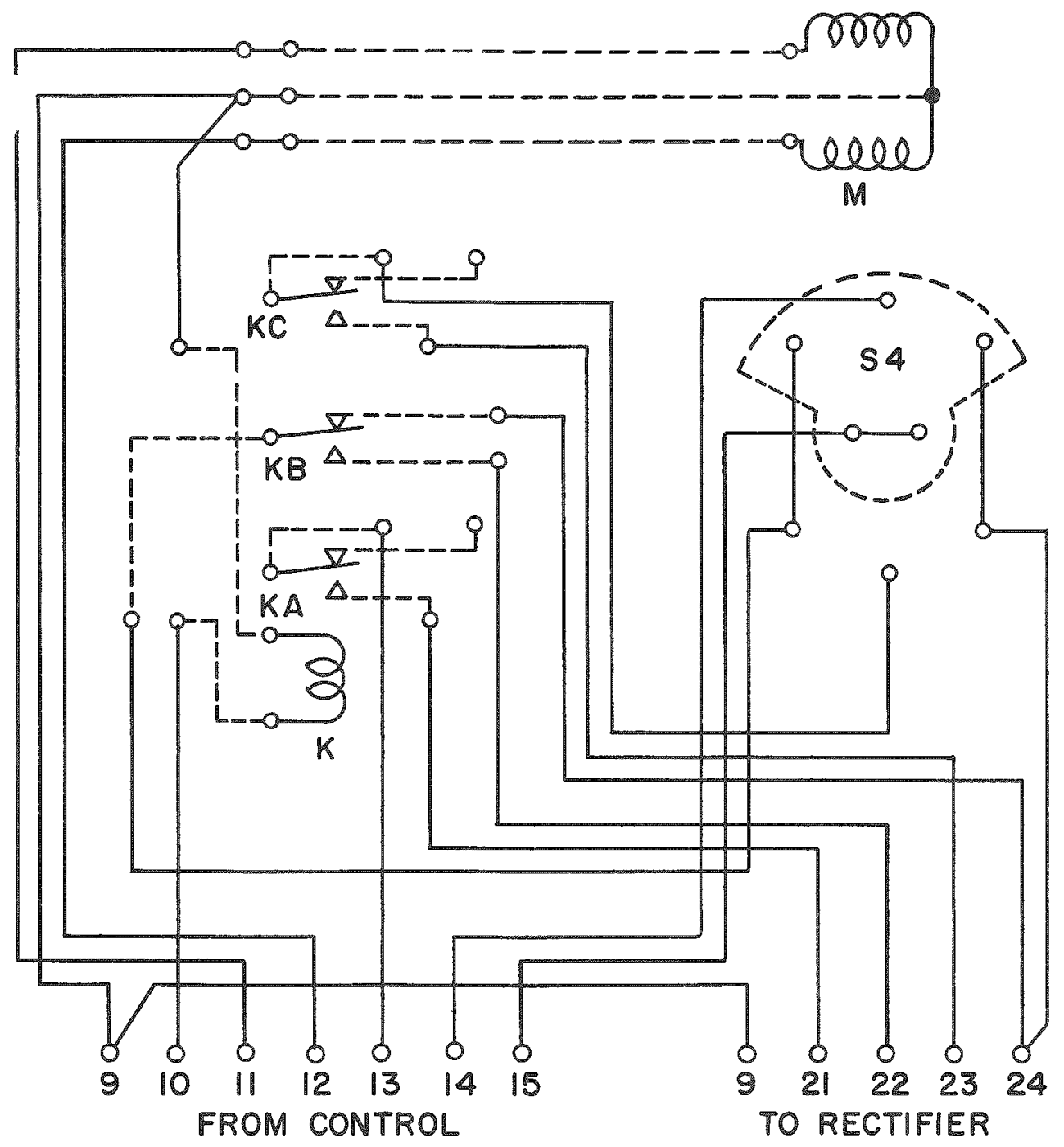

\begin{tabular}{|c|c|}
\hline S4 & Commutator switch, RE-1-23472-D, 3-D, 4-D \\
\hline M & $\begin{array}{l}\text { Gear motor, Merkle-Korff } \# S G-15,30 \text { rpm, } \\
9 \text { lb. in. torque, tandem reversible, } \frac{1}{4} " \text { diam } \times \frac{7}{8} " \\
\text { long horizontal shaft, no base, } 115 \mathrm{VAC}\end{array}$ \\
\hline$K$ & Relay, 3PDT, $115 \mathrm{VAC}$ coil, 15 A contacts \\
\hline
\end{tabular}

SWITCH (Commutator)

Back and Top View 


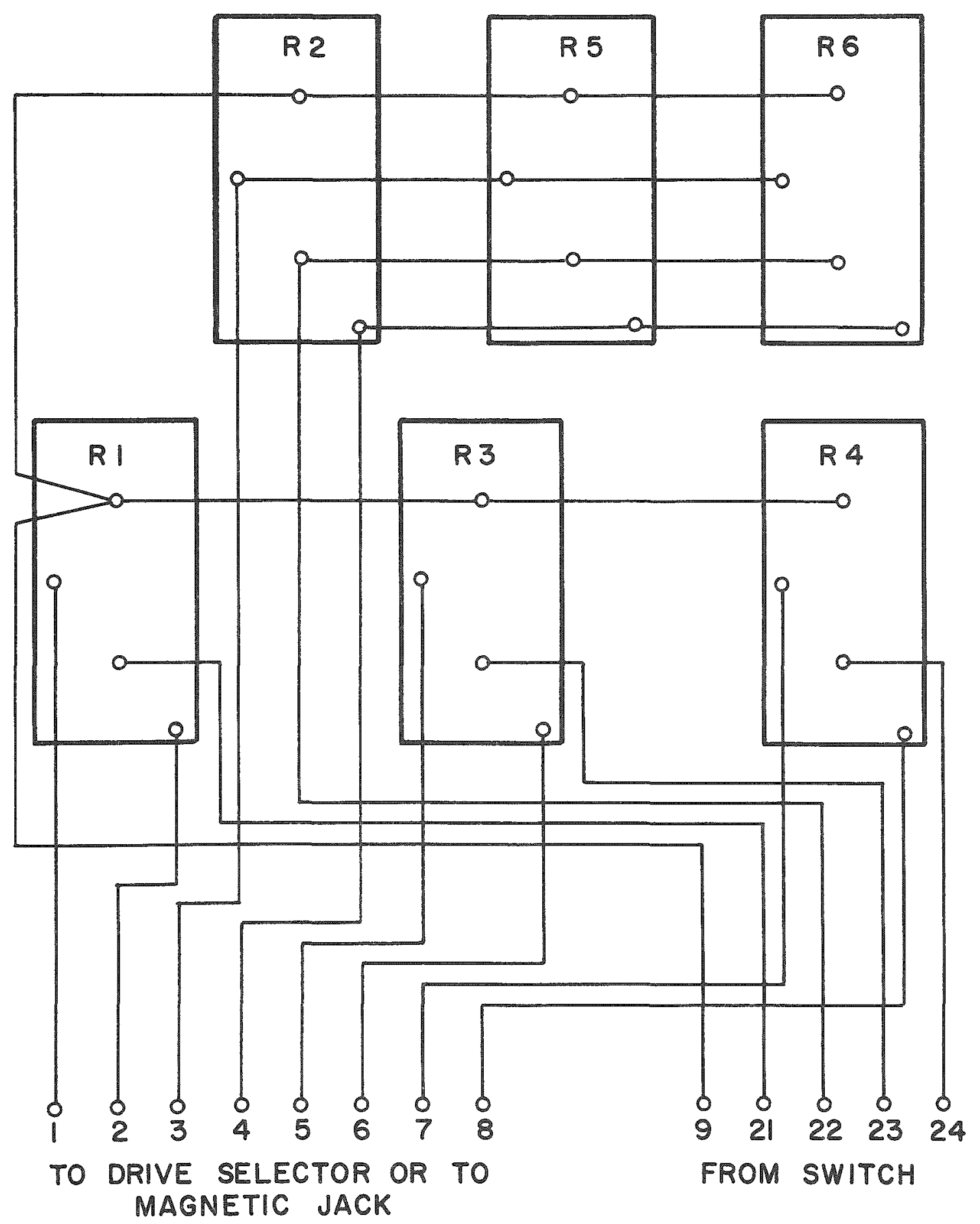

$R 1, R 2, R 3, R 4, R 5, R 6$, SELENIUM RECTIFIER, 5 A, IOOVDC, BRIDGE RECTIFIER (SELENIUM) BACK AND TOP VIEW 

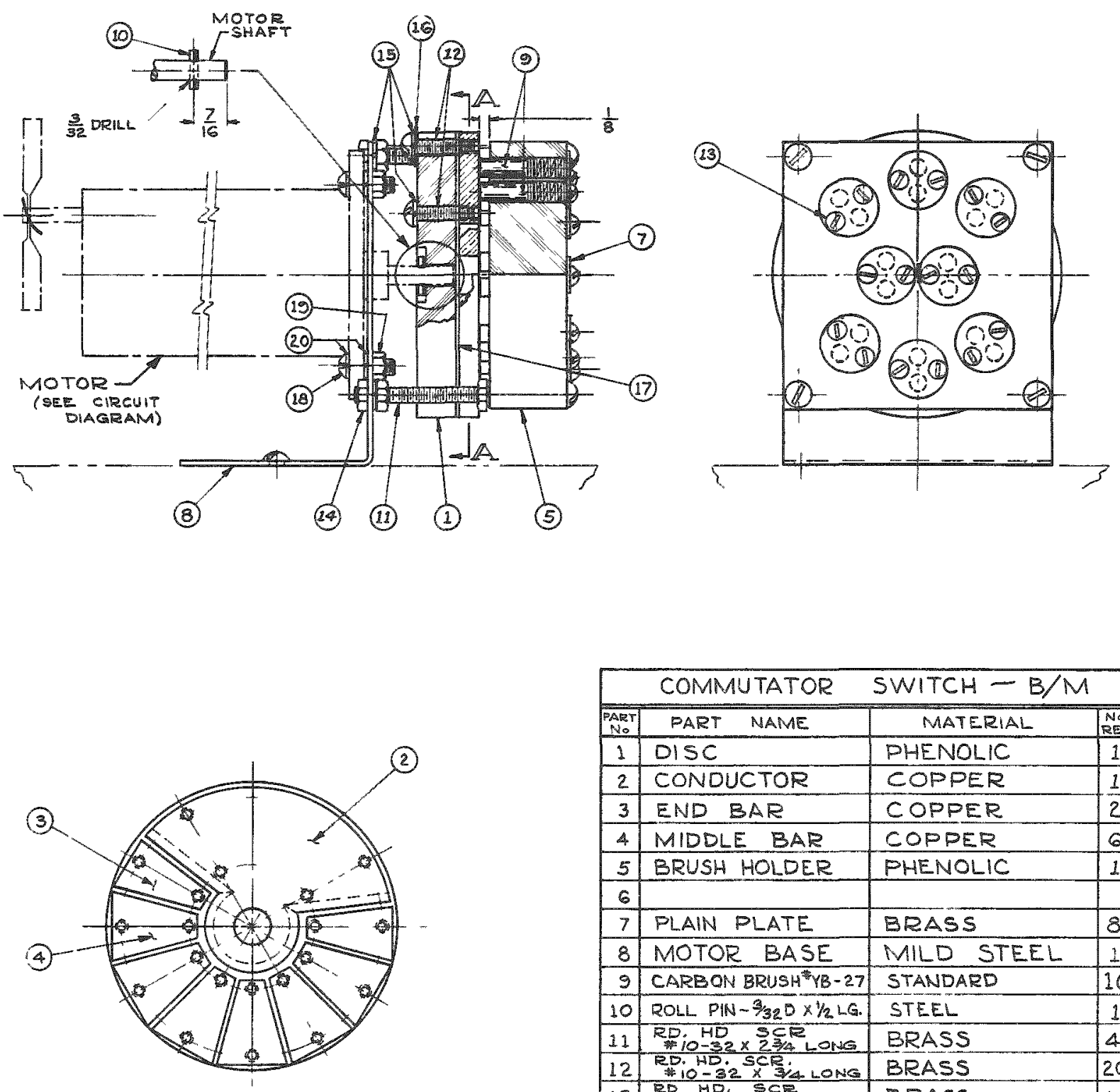

\begin{tabular}{|c|c|c|c|}
\hline & COMMUTATOR & \multicolumn{2}{|l|}{ SWITCH $-B / M$} \\
\hline Not & PART NAME & MATERIAL & No: \\
\hline 1 & DISC & PHENOLIC & 1 \\
\hline 2 & CONDUCTOR & COPPER & 1 \\
\hline 3 & END BAR & COPPER & 2 \\
\hline 4 & MIDDLE BAR & COPPER & 6 \\
\hline 5 & BRUSH HOLDER & PHENOLIC & 1 \\
\hline 6 & & & \\
\hline 7 & PLAIN PLATE & BRASS & 8 \\
\hline 8 & MOTOR BASE & MILD STEEL & 1 \\
\hline 9 & CARBON BRUSH & STANDARD & 16 \\
\hline 10 & ROLL PIN-3/32D $\times 1 / 2$ LG. & STEEL & 1 \\
\hline 11 & RD: $\mathrm{HO}$ 30R & BRASS & 4 \\
\hline 12 & $\begin{array}{l}\text { RDi } \\
\text { HD. SCR } \\
\end{array}$ & BRASS & 20 \\
\hline 13 & RD $140.32 \%$ LONG & BRASS & 16 \\
\hline 14 & HEX. NUT & BRASS & 12 \\
\hline 15 & LOCK WASHER - 10 & STEEL & 28 \\
\hline 16 & FLAT WASHER - 10 & BRASS & 10 \\
\hline 17 & $\begin{array}{l}\text { INSULATOR } \\
\text { I/S2 THK } \times 3^{3 / 4} \text { DIA }\end{array}$ & MICA SHEET & 1 \\
\hline 18 & RD. ${ }^{H D}$ SC SCR $\times 1 / 2$ LNG & BRASS & 4 \\
\hline 19 & HEX ${ }^{N}=8 \mathrm{~s}-32$ & BRASS & 4 \\
\hline 20 & LOCK WASHER 8 & STEEL & 8 \\
\hline
\end{tabular}

COMMUTATOR SWITCH ASSEMBLY

$R E-1-23474$ - D 

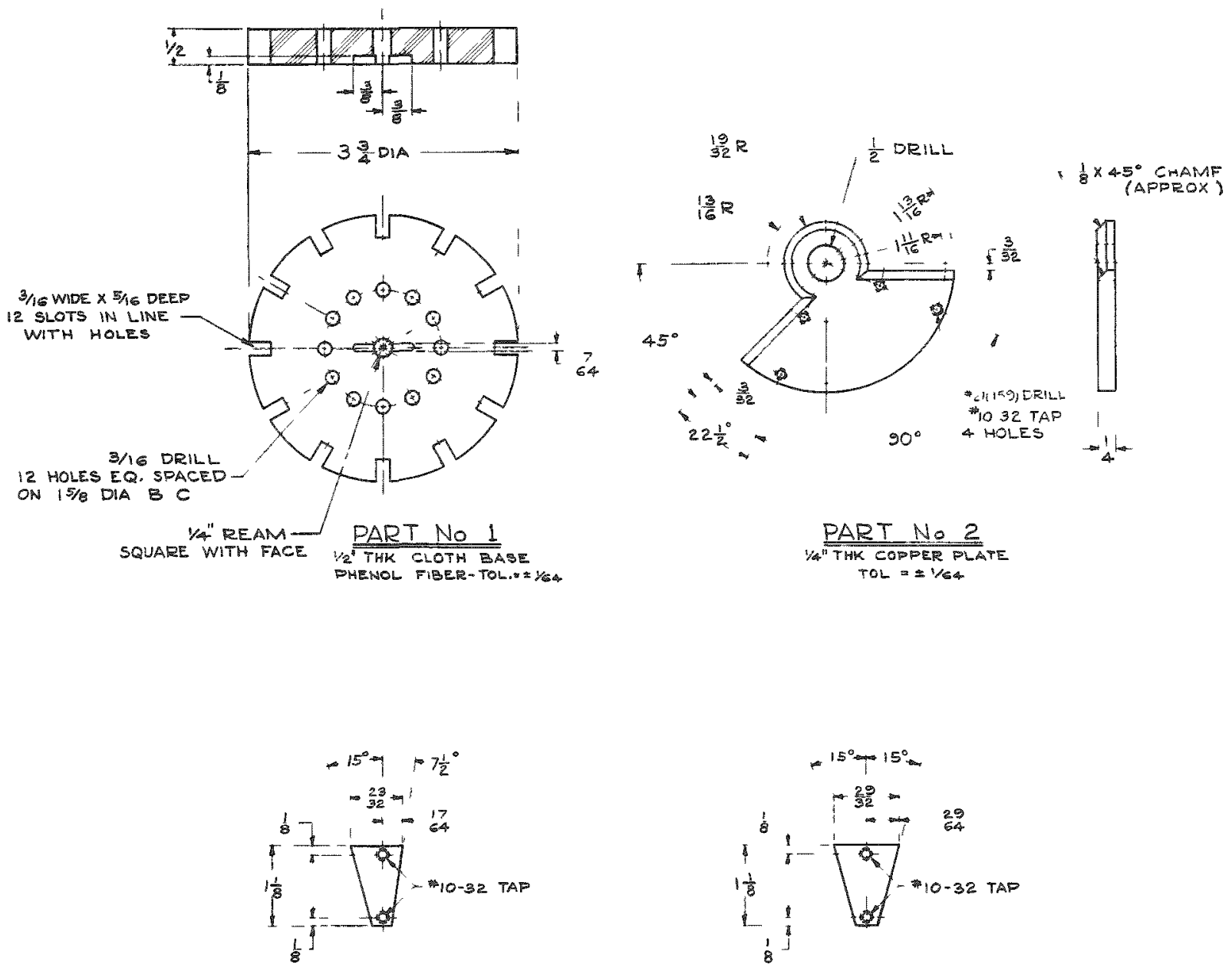

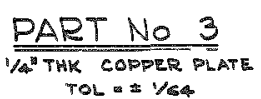

PART NO. 4

YATHK COPFER PLATE

TOL $=1 / 64$

COMMUTATOR SWITCH ROTOR PARTS

$R E-1-23472-D$ 


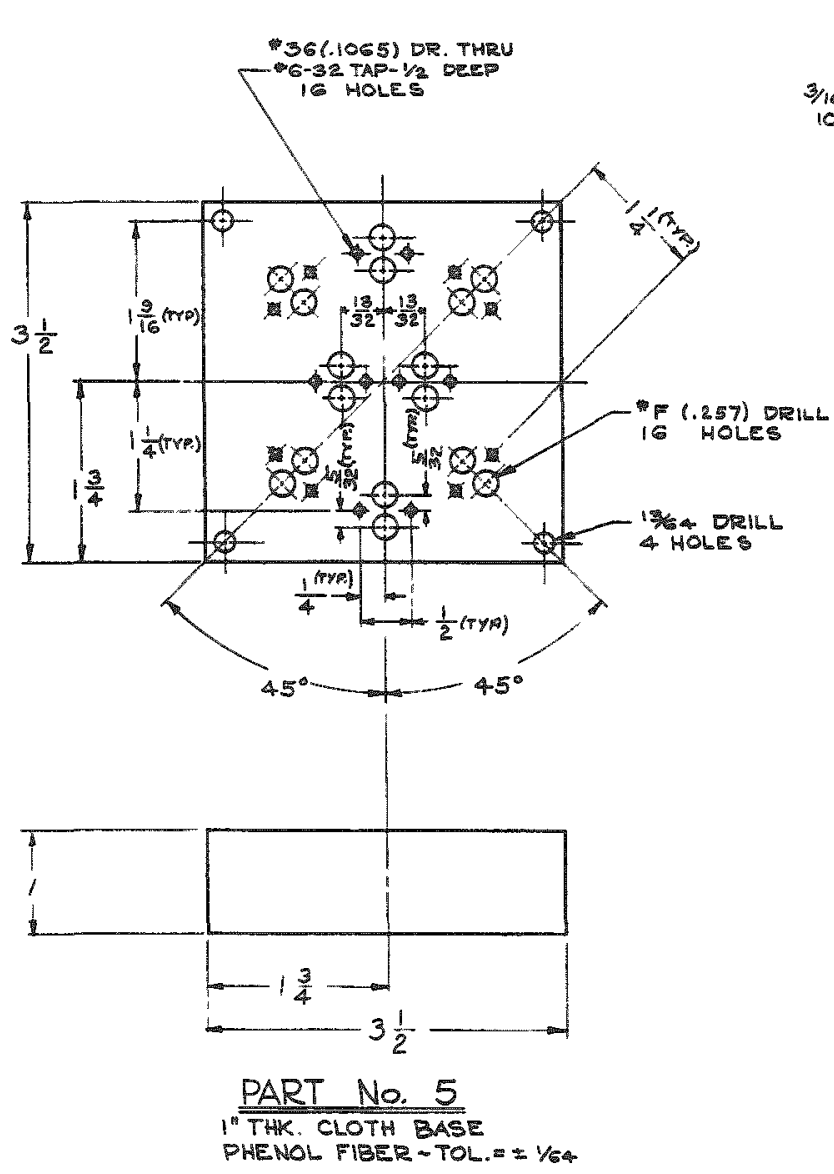

"THK. CLOTH BASE

PHEN FIBER - TOL. 2 I 164

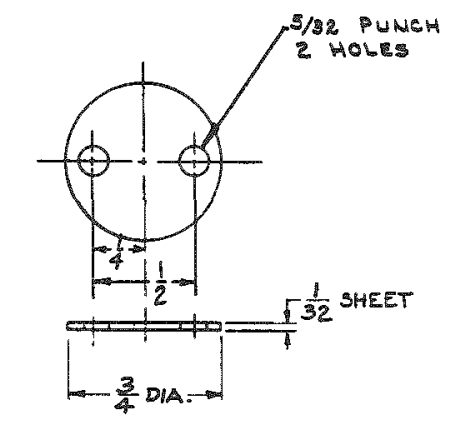

PART No. 7

1/32 THK. BRASS SHEET

COMMUTATOR SWITCH MOUNTING PARTS

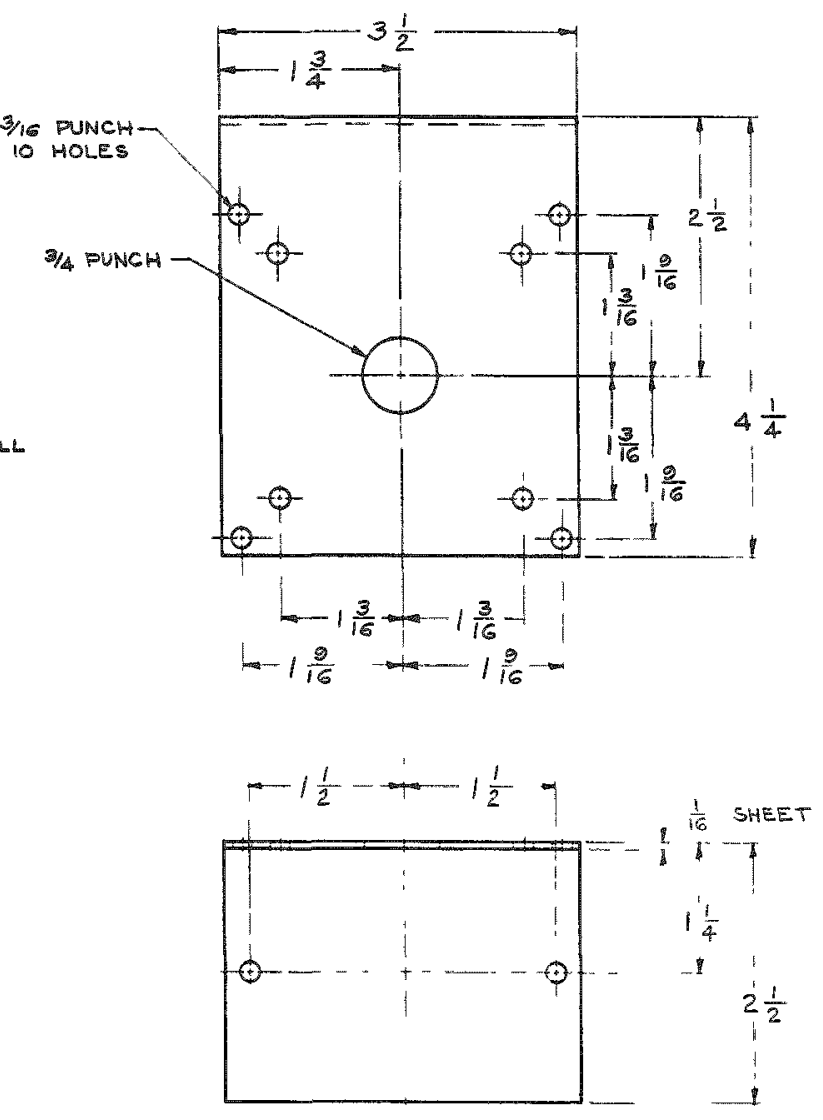

PART No. 8

1/G" THK. MILO STEEL SHEET - TOL $= \pm 1 / 32$ $R E-1-23473-D$ 


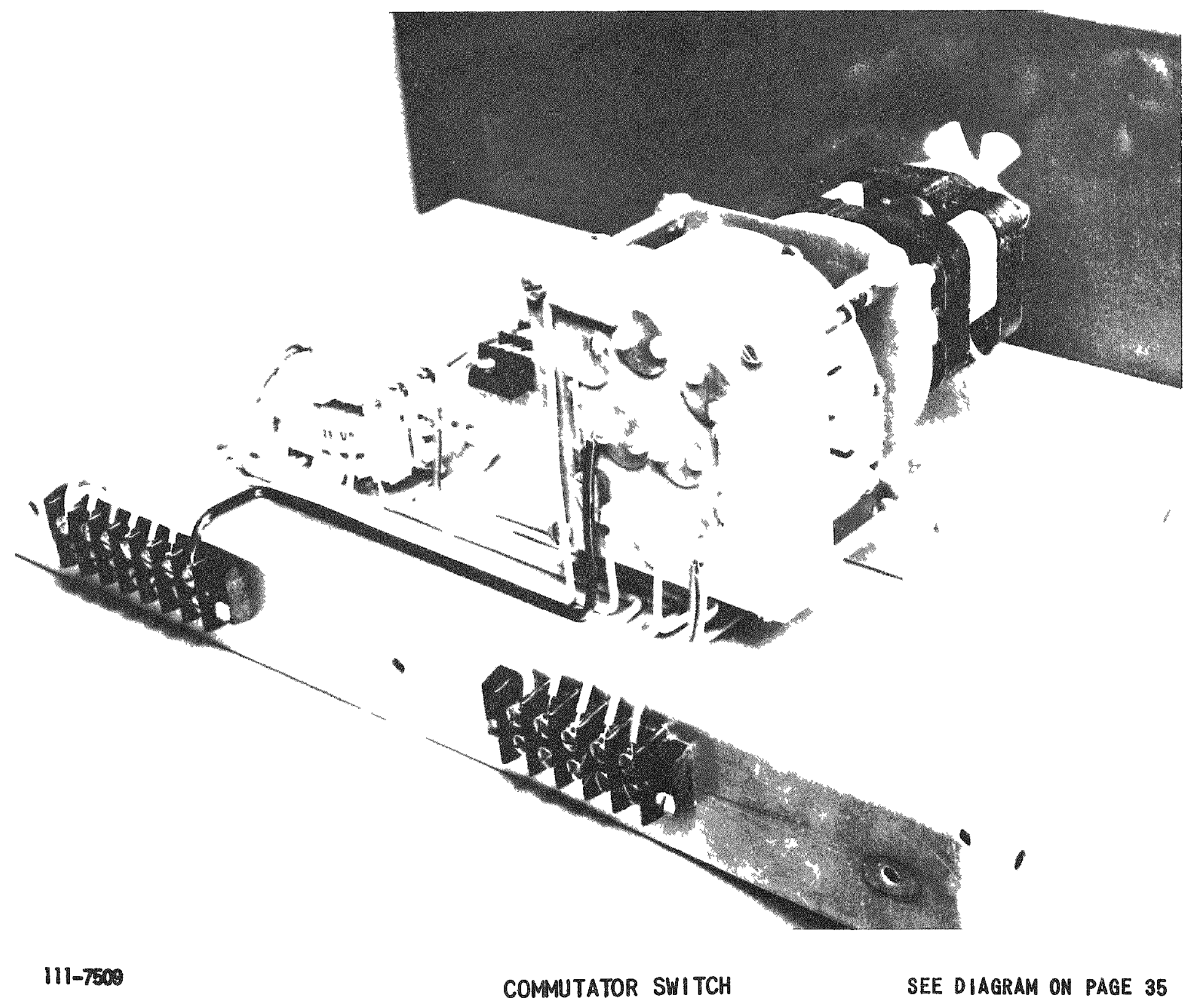


Electrical Components for Five Jack Drives

Although the components are shown on page 81 as mounted in two standard cabinets the position indicatcr meters may be mounted on the ALPR panel in place of the existing position indicators and the ALPR control panel may be used by rewiring it for the magnetic jack drive.

The position indicator components for five drives are:

Five coil as semblies, page 68

One voltage adjustment, page 84

One power supply, page 84

One selector, page 85

Five meter and lights assemblies, page 86

The power supply components for five drives are:

One drive selector. page 83

Two commutator switches, page 74

Two rectifier assemblies page 75 


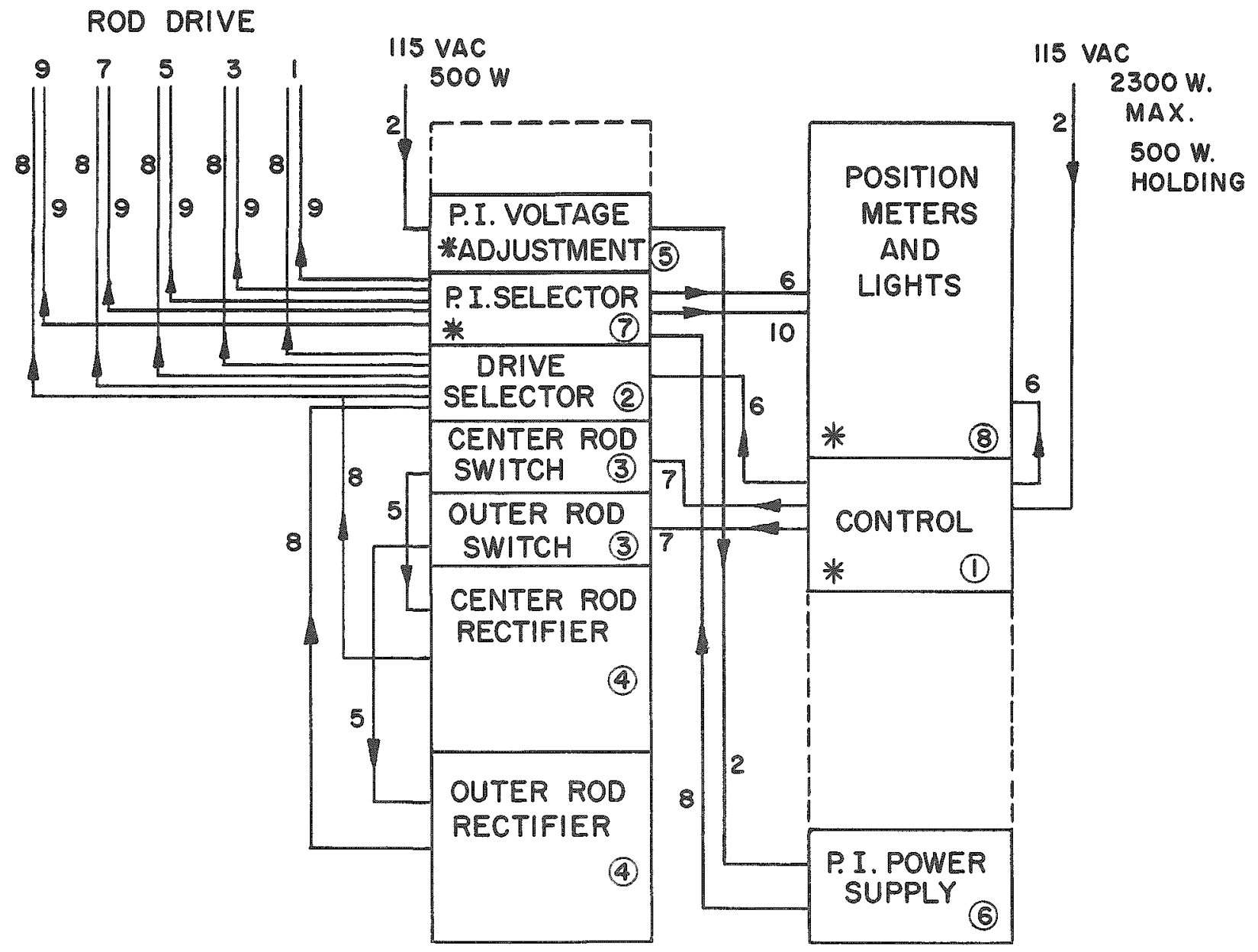

NUMBERS ON CABLES INDICATE CONDUCTORS
* PANELS WHICH HAVE COMPONENTS MOUNTED ON THE FRONT

ALPR MAGNETIC JACK CONTROL ROD DRIVE ELECTRICAL PANEL (FIVE DRIVES) 


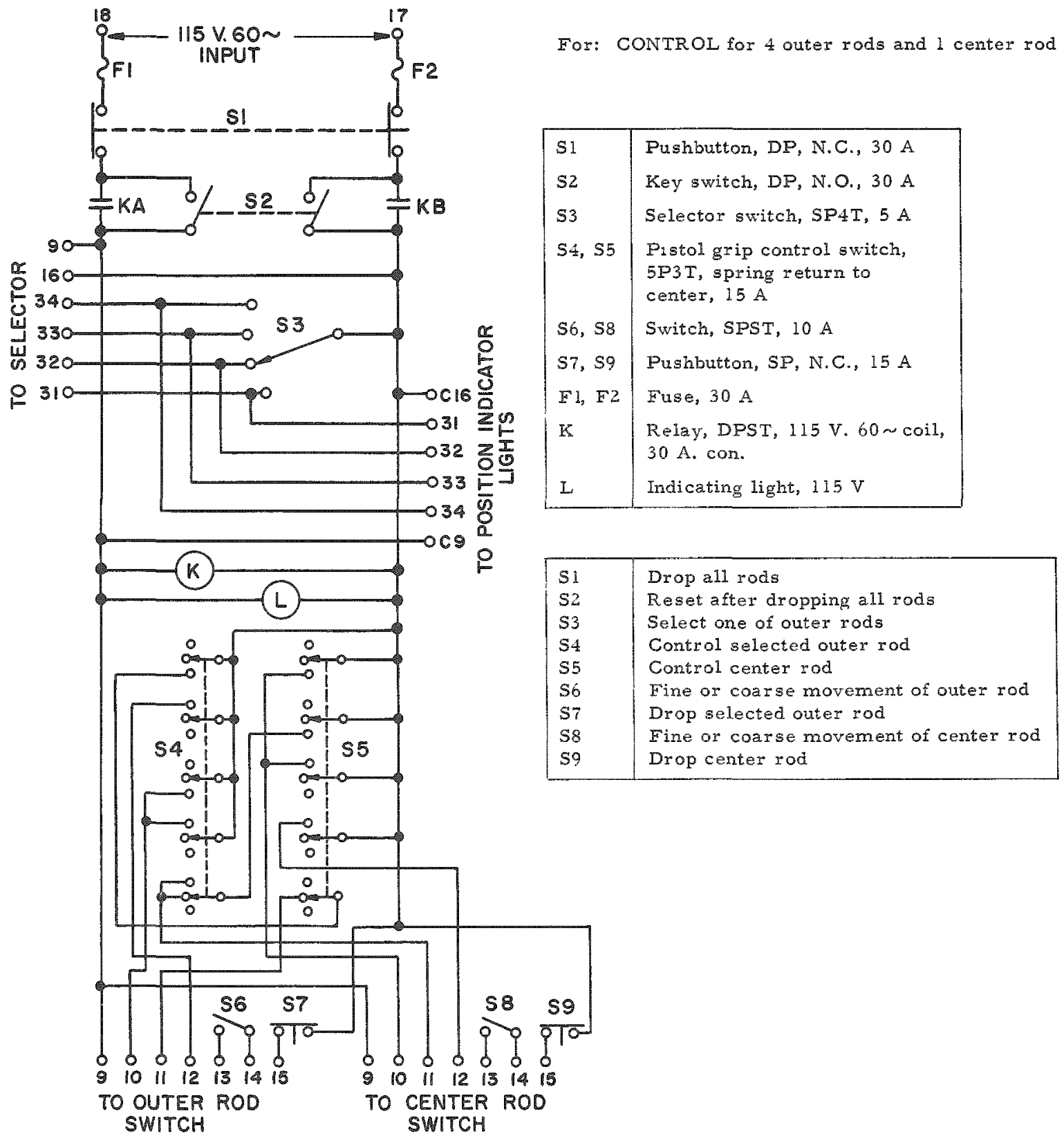

CONTROL

For 4 Outer Rods and 1 Center Rod 


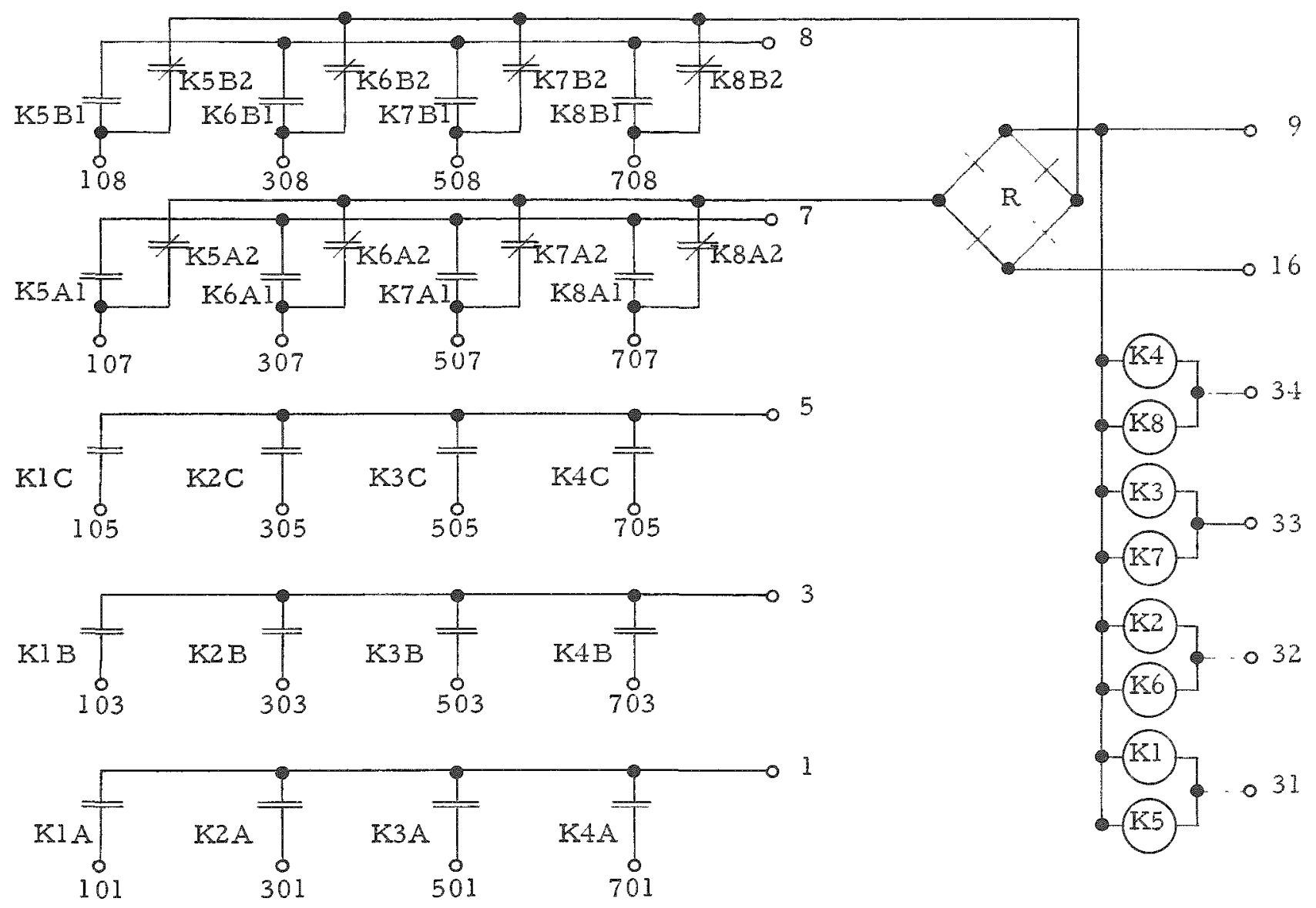

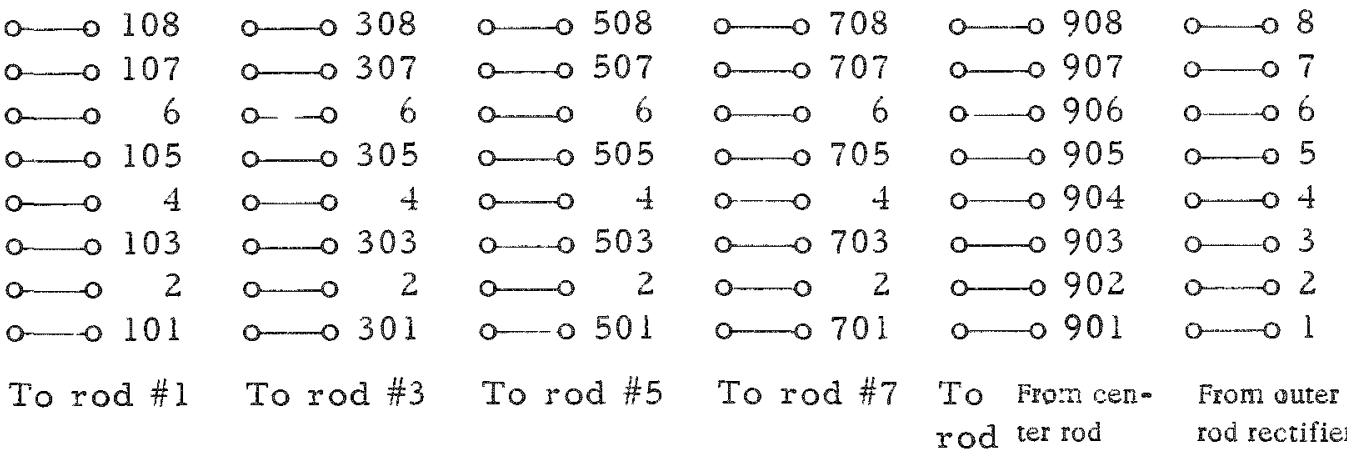

$$
\begin{aligned}
& \text { \#9 rectifier }
\end{aligned}
$$

$\begin{array}{llr}0 & 0 & 9 \\ 0 & 0 & 16 \\ 0 & 0 & 34 \\ 0 & 0 & 33 \\ 0 & 0 & 32 \\ 0 & 0 & 31 \\ \text { From }\end{array}$

control

\begin{tabular}{|l|l|}
\hline $\mathrm{K} 1, \mathrm{~K} 2, \mathrm{~K} 3, \mathrm{~K} 4$ & Relay, 3PST, 115 V.60 coil, 15 A contact \\
\hline $\mathrm{K} 5, \mathrm{~K} 6, \mathrm{~K} 7, \mathrm{~K} 8$ & Relay, DPDT, 115 V.60 coil, 15 A contact \\
\hline $\mathrm{R}$ & Silicon rectifier, 15 A, 125 VDC, bridge \\
\hline
\end{tabular}

DRIVE SELECTOR

Back View 


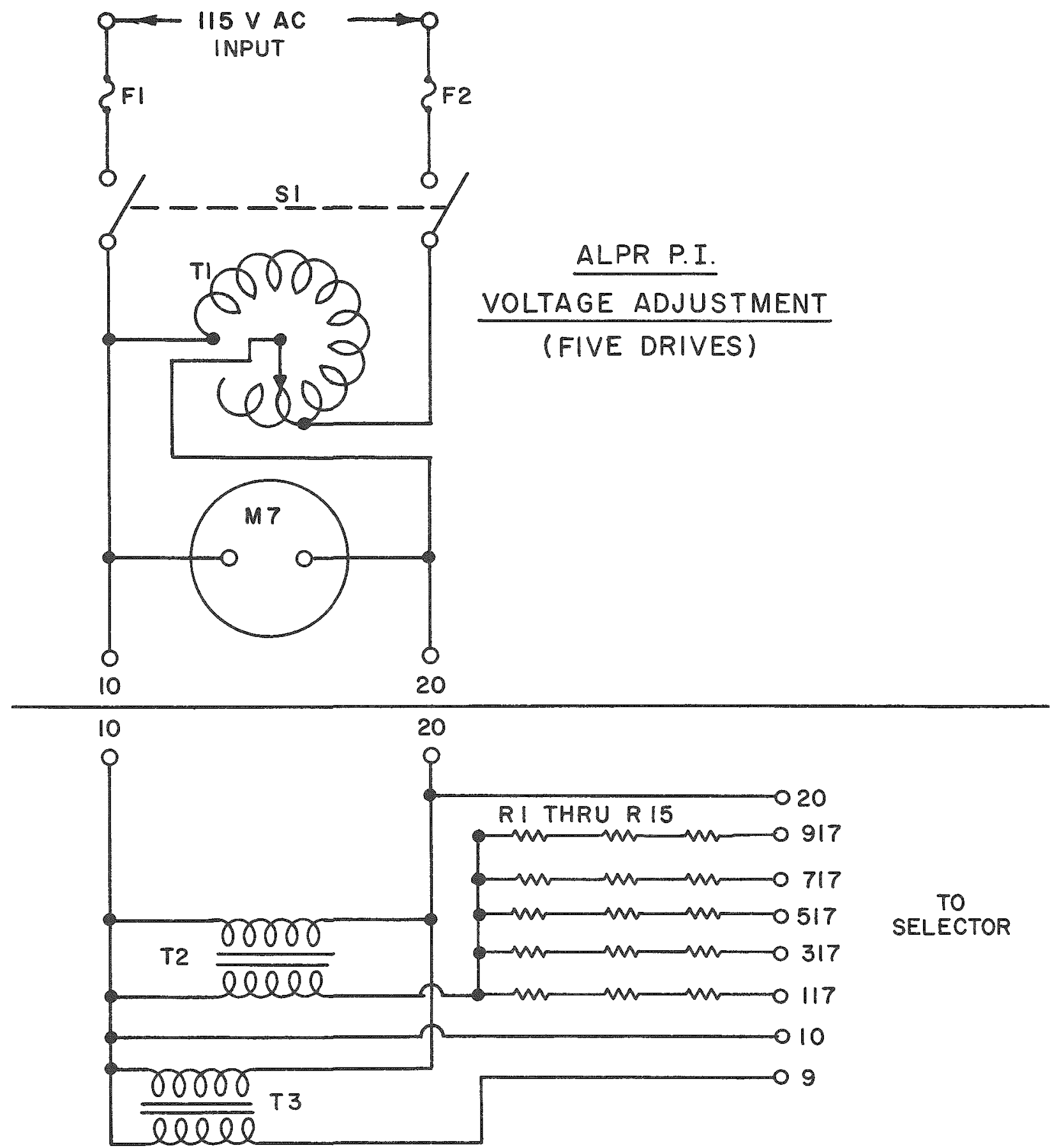

ALPR P.I. POWER SUPPLY

(FIVE DRIVES) 
52

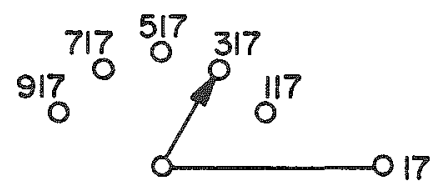

$916 \overbrace{016}^{716} 0_{0}^{516} 0^{316}$
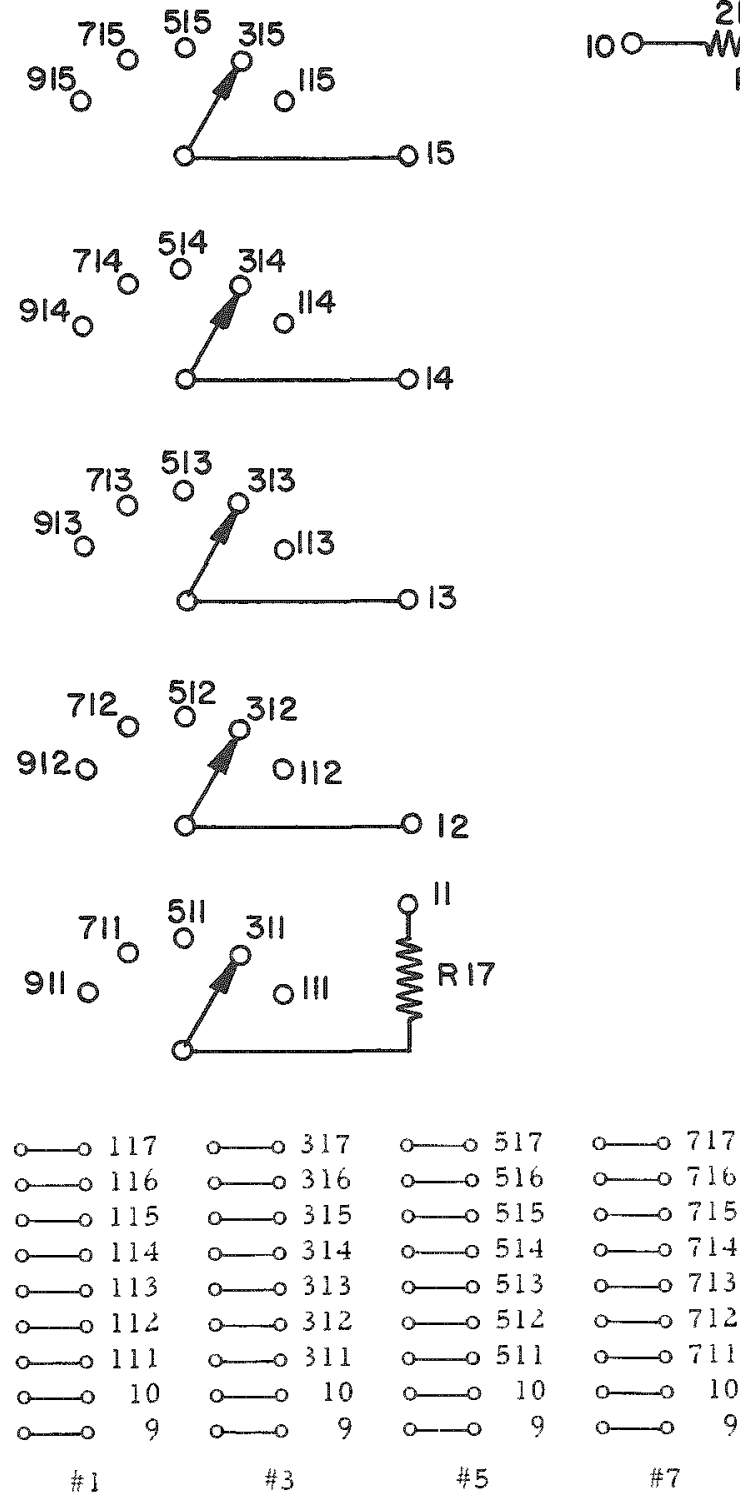

Io position indreator cols
53
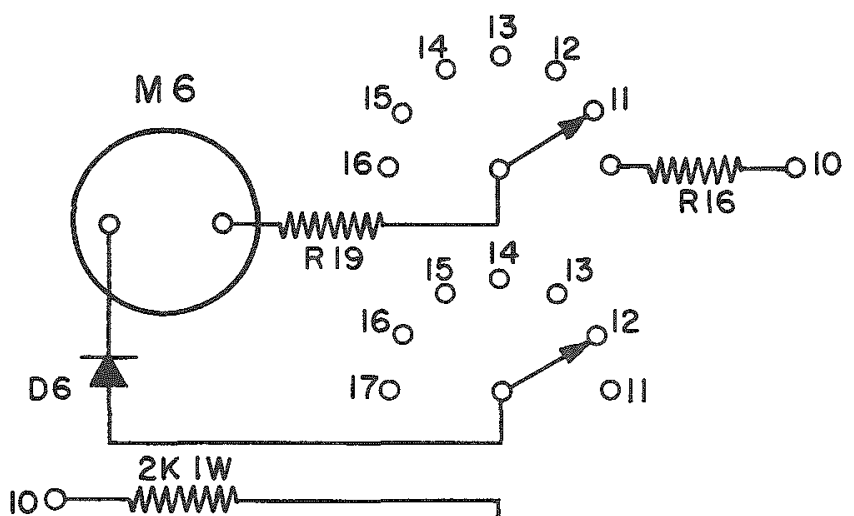

R 18

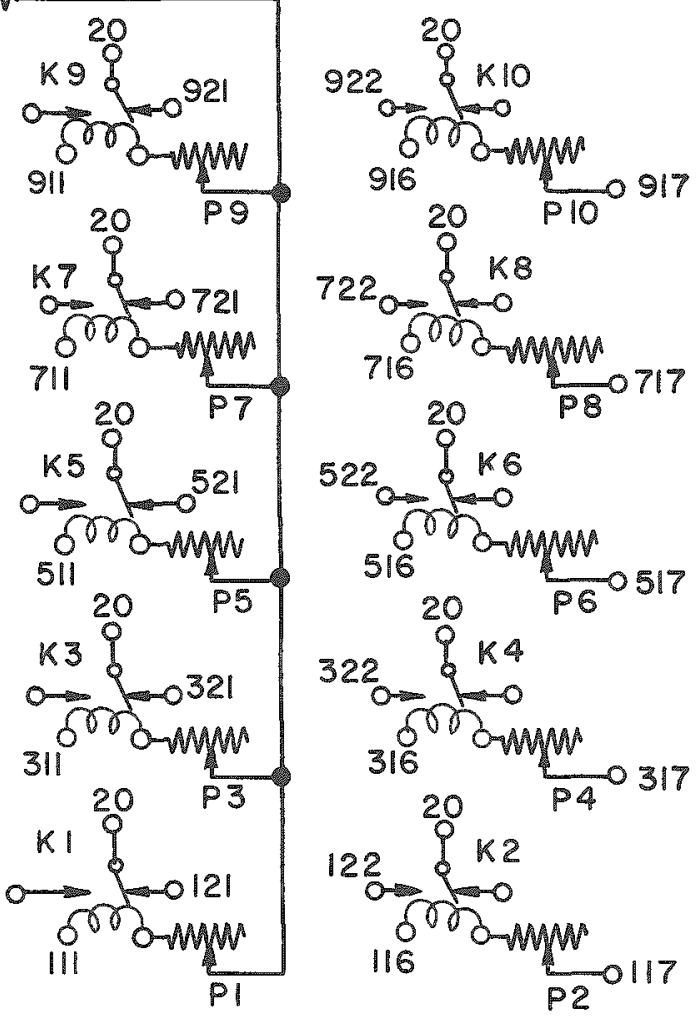

0917
-0916
-0915
-0914
099
-0913
-0912
-0911
-09
0

$0-091$

$2-0 \quad 30$

0.0922

$\infty 717$

$0-0517$

$0-0317$

$0-0117$

$0 \quad 017$

0717

$\multimap 517$

0317

$0-0921$

$a \rightarrow 722$

0721

0522

$0-0 \quad 10$

0117

0521

$0 \quad 10 \quad 0 \quad 0322$

moters

œ $\quad 9 \quad 0 \quad 321$

Erom powe $1^{\circ}$ supply

0122

lights

ALPR P. I. SELECTOR (Five drives)

Back and top view 

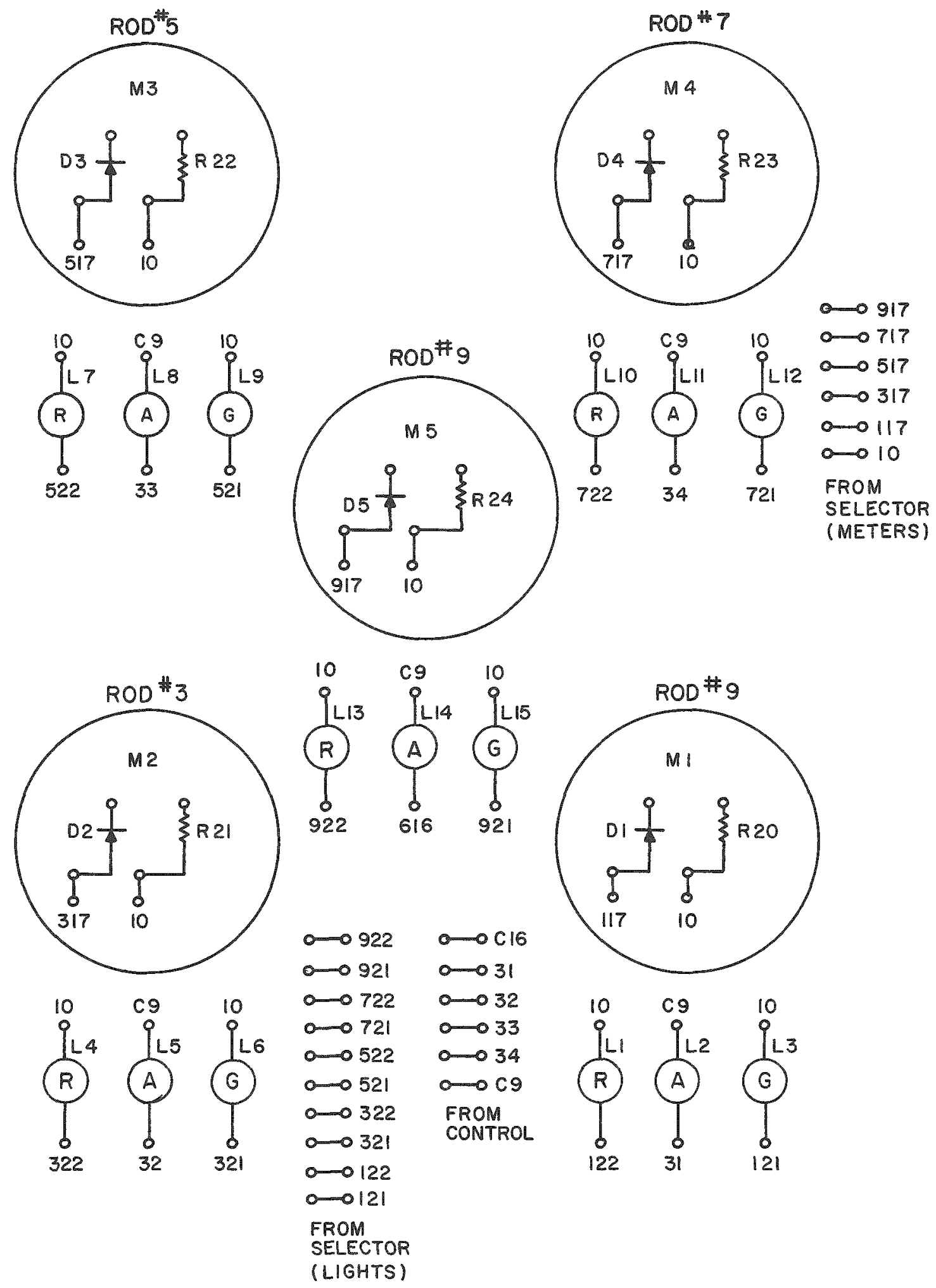

ALPR P. I. METERS AND LIGHTS

(FIVE DRIVES)

BACK VIEW 


\begin{tabular}{|c|c|}
\hline$F 1, F 2$ & Fuse, $15 \mathrm{~A}$ \\
\hline T 1 & $\begin{array}{l}\text { Adjustable transformer } 115 \mathrm{~V} \text {. input, } \\
0-135 \mathrm{~V} \text {. output. } 7.5 \mathrm{~A}\end{array}$ \\
\hline $\mathrm{T} 2$ & $\begin{array}{l}\text { Power transformer: } 115 \mathrm{~V} \text {. input, } \\
460 \mathrm{~V} \text {. output, } 500 \mathrm{~W}\end{array}$ \\
\hline T3 & $\begin{array}{l}\text { Filament transformer, } 117 \mathrm{~V} \text {. input, } 6.3 \mathrm{~V} \text {. output, } \\
10 \mathrm{~A}\end{array}$ \\
\hline R1through R15 & Resistor, $1000 \Omega: 100 \mathrm{~W}$ \\
\hline $\mathrm{R} 16$ & Resistor, $2200 \Omega, 1 \mathrm{~W}$ \\
\hline R 17 & Resistor, $300 \Omega, 1 \mathrm{~W}$ \\
\hline $\mathrm{R} 18$ & Resistor, $2000 \Omega, 1 \mathrm{~W}$ \\
\hline R 19 & Resistor, $1500 \Omega, 1 \mathrm{~W}$ \\
\hline R20 through R24 & Resistor, $74400 \Omega, \quad 1 \mathrm{~W}$ \\
\hline M1 through M5 & Microammeter, $0-300,8 \frac{3}{4} "$ long-scale, GE \#DB-16 \\
\hline M6 & Milliammeter, $0-1,4 \frac{1}{4} "$ long-scale, $G E \# D B-18$ \\
\hline M7 & Voltmeter, 0-130, 4 " exp. long-scale, GE \#AB-18 \\
\hline Dl through D6 & Silicon diode, PSI type IN628 \\
\hline $\mathrm{L} 1, \mathrm{~L} 4, \mathrm{~L} 7 . \mathrm{L} 10, \mathrm{~L} 13$ & Light: red, $115 \mathrm{~V}$ \\
\hline $\mathrm{L} 2, \mathrm{~L} 5, \mathrm{~L} 8, \mathrm{~L} 11, \mathrm{~L} 14$ & Light, amber, $115 \mathrm{~V}$ \\
\hline L3, L6, L9, L12, L15 & Light, green, $115 \mathrm{~V}$ \\
\hline S1 & Switch, DPST, $15 \mathrm{~A}$ \\
\hline $\mathbf{s 2}$ & Selector switch, 7 sec, 5 pos, N-S \\
\hline S3 & Selector switch, 2 sec, 7 pos, N-S \\
\hline $\mathrm{Kl}$ through $\mathrm{K} 10$ & Sensitive relay, sigma \#5RS-12AS-S1L \\
\hline Pl through P10 & Potentiometer. $1000 \Omega: 1 \mathrm{~W}$ \\
\hline
\end{tabular}



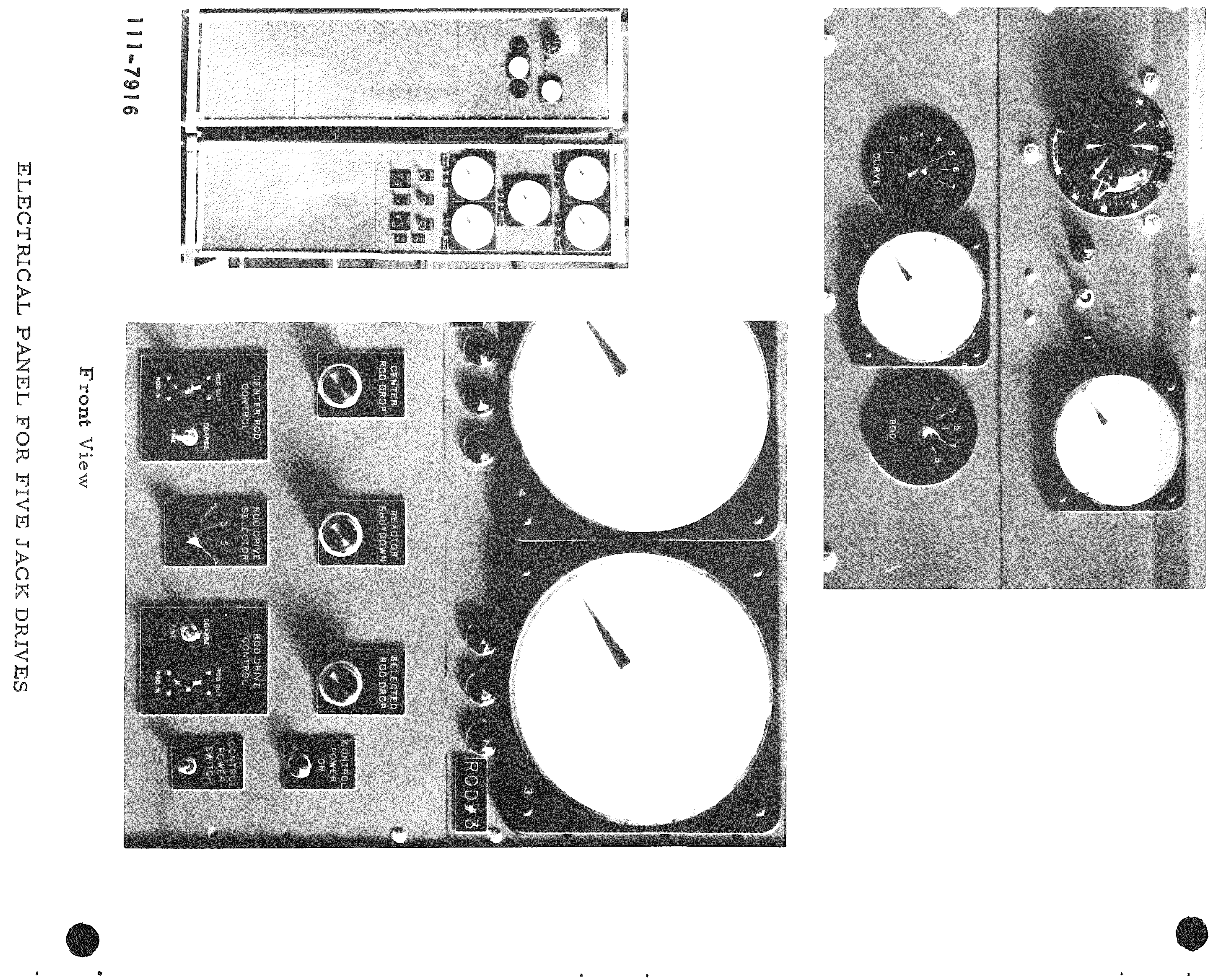


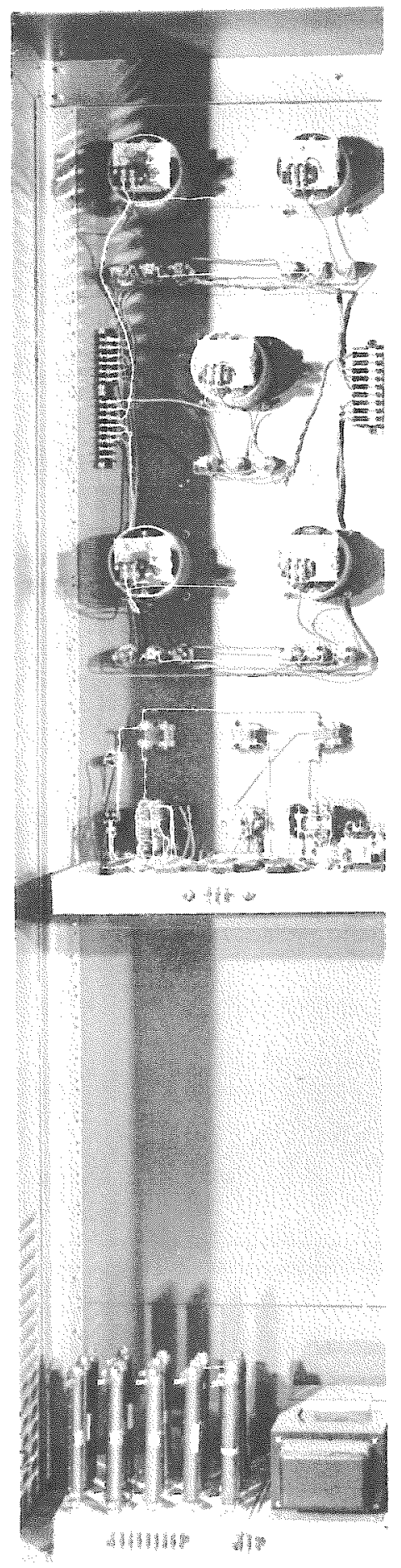

$111-7506$

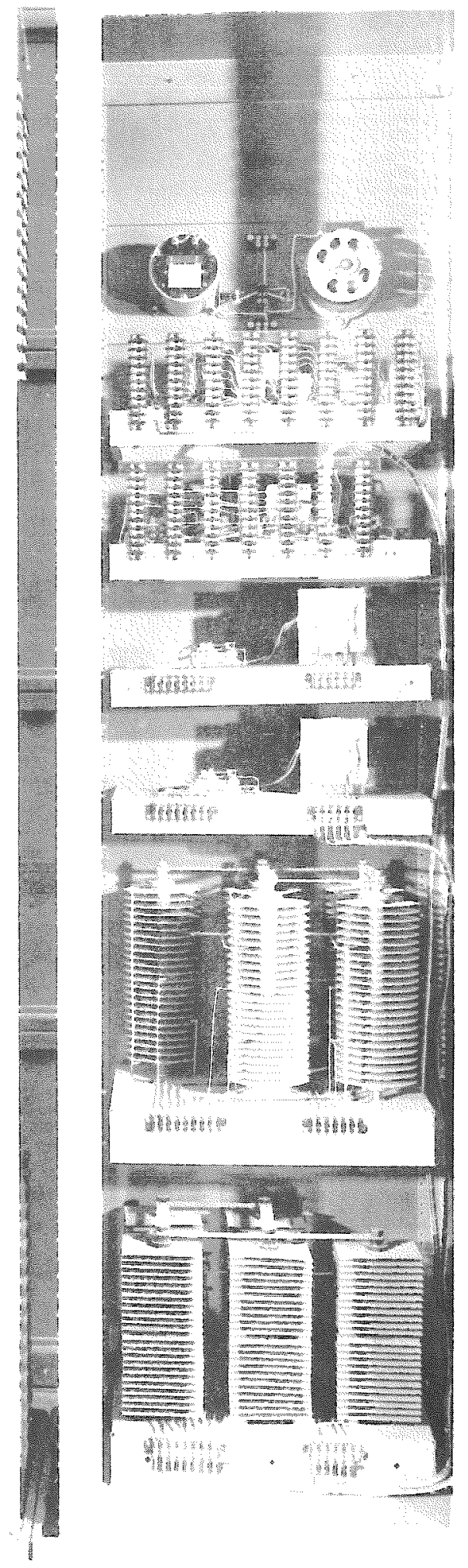

BACK VIEW 
Test Results

The components of the six \#27 magnetic jack drives are numbered from 1 through 6 . The first drive to be installed on ALPR, the test data for which are given here, is numbered as follows: jack \#2, drive rod \#5, rod connection \#2, position indicator coils \#3, position indicator meter \#2.

The jack was tested for 15 days under simulated reactor conditions of 300 -psig steam on the test fasility which was used to test the rack-andpinion drives. The jack was in operation $77 \%$ of the time.

Rod connection \#1 was used in this test and in the tests of the other jacks. Rod connection \#2 will be given a test before shipping.

The extension rod has a diametral clearance of $\frac{1}{32}$ in. where it goes into the steam space. This clearance is small enough to keep water up in the drive, thus allowing the jack to be cooler than the reactor (420F)。 The flange at the bottom of the jack was $390 \mathrm{~F}$ in still air. It was $340 \mathrm{~F}$ with a 12 in. fan blowing on it.

The step length. especially in the down direction, is effected by the temperature of the coils, the presence of water in the jack, and the coeffi cient of friction. The step length in the up direction was 0.087 to 0.098 in. and in the down direction was 0.122 to $0.142 \mathrm{in}$. The switch made 29 rpm, thus giving a rod speed of 2.5 to 2.8 in. per minute up and 3.5 to $4.1 \mathrm{in}$. per minute down.

The minimum amount of current to hold the rod was 0.40 to 0.60 ampere. The operating current was 2.6 to 4.1 amperes. The control rod assembly weighed 110 pounds.

A commutator switch, which was used on this and other tests, failed after 980,000 revolutions ( 2 years assuming the control rod is moving $3.2 \%$ of the time) due to burning of the copper, which caused one of the carbon. brushes to lock the rotor. The switch was repaired by refacing the commutator. This may be done several times without reducing the thickness of the copper too much.

The position indicator was tested with a magnetic jack on a test facility that showed the position of the rod through a sight glass while the drive contained water at 300 psig and at various temperatures. At $100 \mathrm{~F}$ the position indicator input was set at 110,0 volts and at 230 F it was set at 105.0 volts. The following table shows the position indicator error. 


\begin{tabular}{|c|c|c|c|}
\hline \multirow{2}{*}{$\begin{array}{c}\text { Actual } \\
\text { Position }\end{array}$} & \multicolumn{2}{|c|}{ Coarse Meter } & \multirow{2}{*}{$\begin{array}{c}\text { Fine } \\
\text { Meter } \\
\text { at } 230 \mathrm{~F}\end{array}$} \\
\hline & $100 F$ & $230 F$ & \\
\hline 0 & 0.1 & -0.1 & -0.10 \\
\hline 5 & 4.8 & 4.7 & 4.88 \\
\hline 10 & 9.8 & 9.7 & 10.00 \\
\hline 15 & 15.0 & 15.0 & 14.98 \\
\hline 20 & 20.0 & 20.2 & 20.02 \\
\hline 25 & 24.9 & 25.2 & 25.02 \\
\hline 30 & 29.9 & 30.5 & 30.05 \\
\hline
\end{tabular}


- 
APPENDIX C

DETAILS OF THE HIGH PRESSURE AND THE EBWR MAGNETIC JACKS

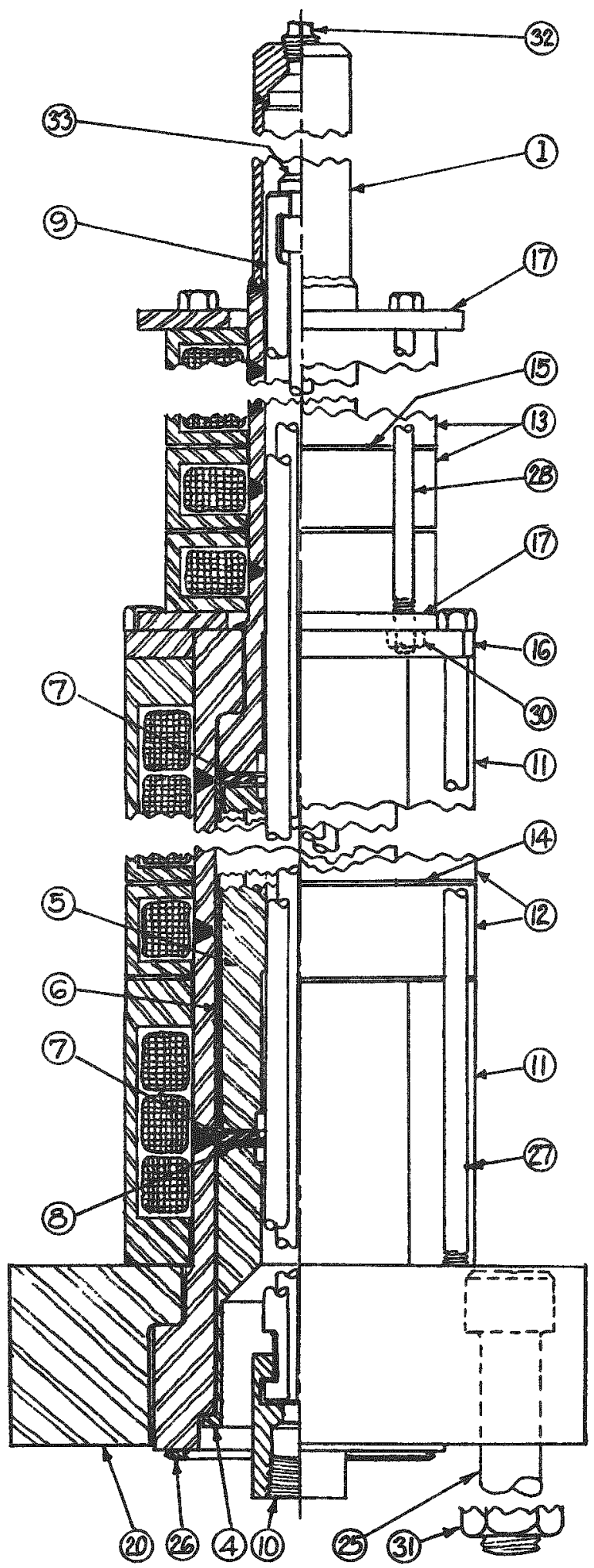



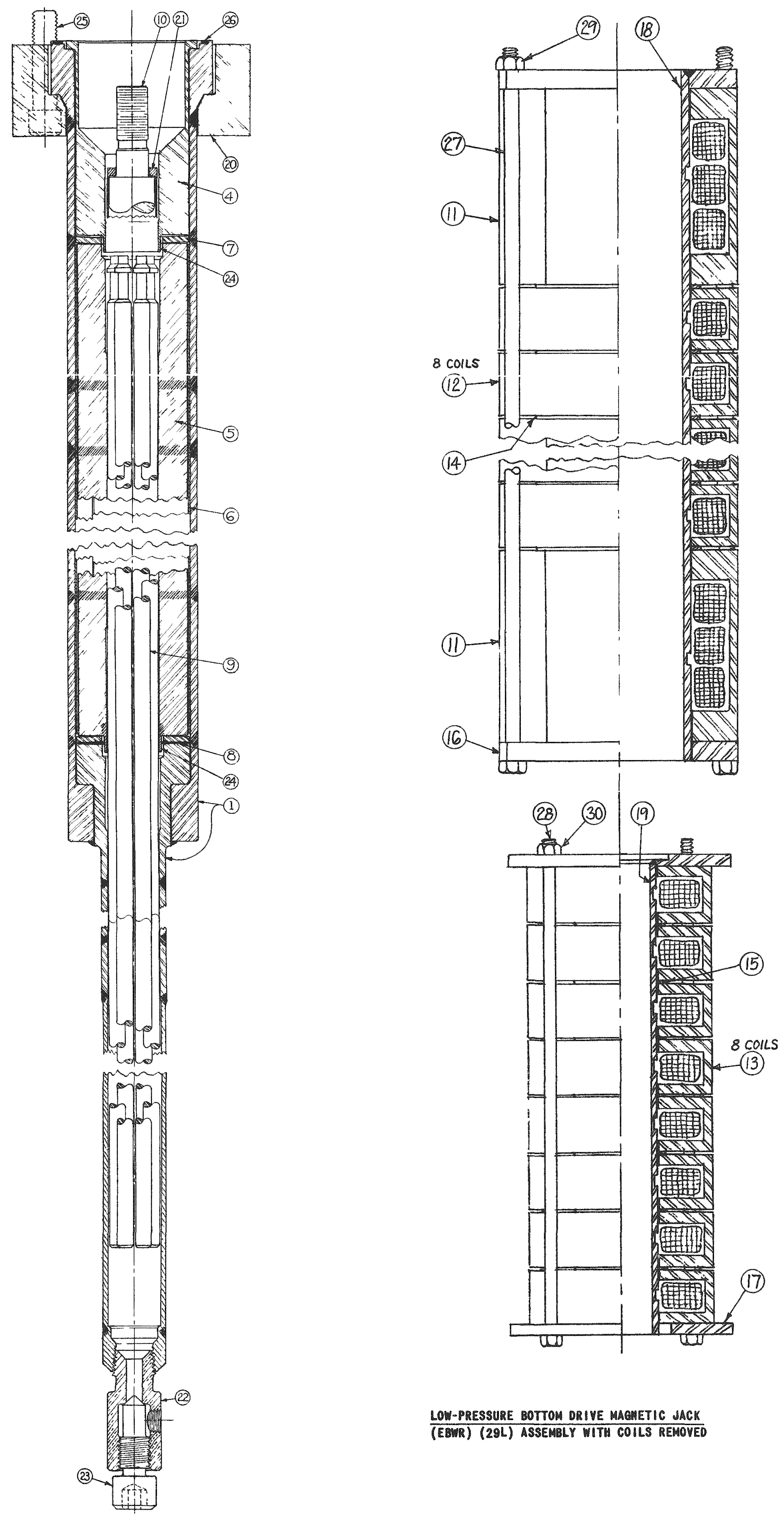
COIL WIRING DIAGRAM

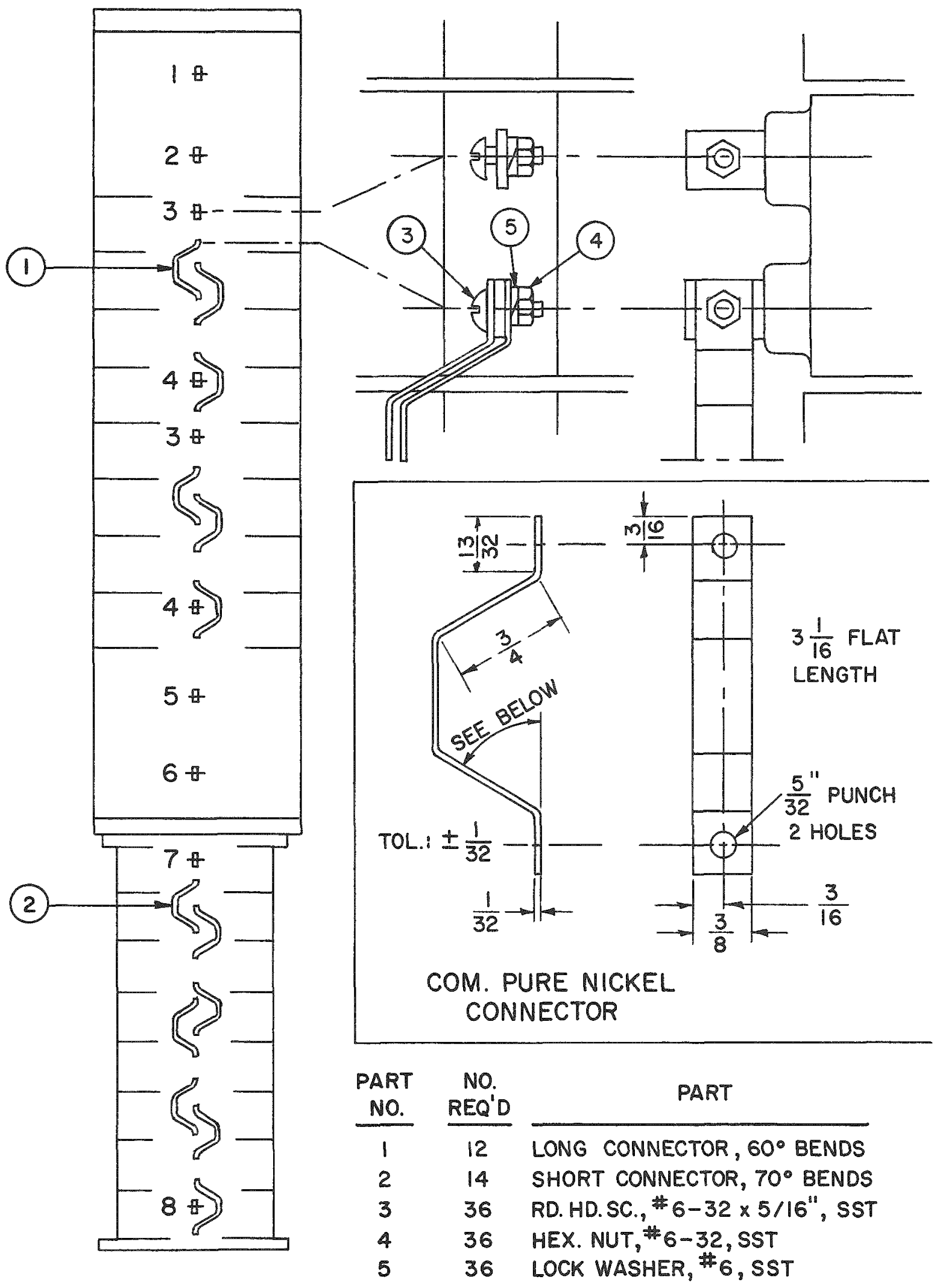


DRA WING LIST FOR THE HIGH-PRESSURE MAGNETIC JACK (29H)

\begin{tabular}{|c|c|c|c|c|}
\hline $\begin{array}{l}\text { Part } \\
\text { No. }\end{array}$ & $\begin{array}{c}\text { Number } \\
\text { Required }\end{array}$ & Part & $\begin{array}{l}\text { Drawing } \\
\text { Number }\end{array}$ & $\begin{array}{c}\text { Page } \\
\text { No. }\end{array}$ \\
\hline \multirow[t]{10}{*}{1} & 1 & Pressure shell & RE-1-31081-A & 98 \\
\hline & 1 & Body & $R E-1-31085-A$ & 99 \\
\hline & 1 & Flange & $R E-1-31086-A$ & 99 \\
\hline & 1 & Tube & $R E-1-31087-A$ & 99 \\
\hline & 1 & Head & $R E-1-31088-A$ & 99 \\
\hline & 1 & Extension & $R E-1-31089-A$ & 100 \\
\hline & 1 & Flange & $R E-1-31090-A$ & 100 \\
\hline & 1 & Tube & $R E-1-31091-A$ & 100 \\
\hline & 1 & Pipe & RE-1-31092-A-1 & 100 \\
\hline & 1 & Cap & $R E-1-31092-A-2$ & 100 \\
\hline 4 & 1 & Plug & RE-1-31082-A & 98 \\
\hline 5 & 1 & Armature & $R E-1-31083-A$ & 98 \\
\hline 6 & 3 & Non-magnetic sleeve & $R E-1-31093-A-1$ & 102 \\
\hline 7 & 2 & Cushion washer & $R E-1-31093-A=2$ & 102 \\
\hline 8 & 1 & Shim (149"long) & $R E-1-31093-A-3$ & 102 \\
\hline 9 & 6 & $\{$ for $\operatorname{six}-\}$ & $R E-1-18795-B$ & 101 \\
\hline 10 & 1 & Rod connector (ft. travel) & $R E-1-17894-A$ & 101 \\
\hline 33 & 1 & Fillex rod & R.E-1-18799-A & 101 \\
\hline \multirow[t]{3}{*}{11} & 2 & Move coil & RE-1-31095-A & 103 \\
\hline & 4 & End plate & $R E-1-31096-A$ & 103 \\
\hline & 2 & Ring & RE-1-31097-A & 103 \\
\hline \multirow[t]{4}{*}{12} & 8 & Grip coil & $R E-1-31098-A$ & 104 \\
\hline & 16 & End plate & $R E-1-31099-A-1$ & 104 \\
\hline & 8 & Ring & $R E-1-31099-A-2$ & 103 \\
\hline & 14 & Coil & $R E-1-31100-A$ & 104 \\
\hline \multirow[t]{6}{*}{13} & 8 & Hold coil & $R E-1-31101-A$ & 105 \\
\hline & 16 & End plate & $R E-1-31102-A-1$ & 105 \\
\hline & 8 & Ring & $R E-1-31102-A-2$ & 105 \\
\hline & 8 & Coil & RE-1-31103-A & 105 \\
\hline & -- & Coil assembly notes & $R E-1-31104-A$ & 105 \\
\hline & 44 & Terminal & $R E-1-21540-A$ & 49 \\
\hline 14 & 9 & Large coil spacer & $R E-1-31094-A-1$ & 102 \\
\hline 15 & 7 & Small coil spacer & RE-1-31094-A-2 & 102 \\
\hline 16 & 1 & Large coil clamp & $R E-1-31094-A-3$ & 102 \\
\hline 17 & 2 & Small coil clamp & $R E-1-31094-A-4$ & 102 \\
\hline 20 & 1 & Flange ring & $R E-1-31084-A$ & 98 \\
\hline 25 & 8 & Flange bolt, soc. hd. sc, 1 & $-7 \times 6 \frac{1}{2}$, st. & \\
\hline 26 & 1 & Flange gasket, Flexitallic & $\# R 3-25 K$ & \\
\hline 27 & 4 & Large tie bolt, Hex hd., $\frac{1}{2}$ & $13 \times 29 \frac{1}{4}$, st. & \\
\hline 28 & 4 & Small tie bolt, Hex hd., $\frac{3}{8}-$ & $16 \times 15 \frac{1}{8}, s t$ & \\
\hline 30 & 2 & Small nut, Hex, $\frac{3}{8}-16$, st. & & \\
\hline 31 & 8 & Flange nut, Hex, $1 \frac{1}{4}-7$, st. & & \\
\hline 32 & 1 & Pipe plug, $\frac{3}{8}$, sst. & & \\
\hline
\end{tabular}

RE-31079-A 
DRAWLNG LIST FOR THE EBWR MAGNETIC JACK (29L)

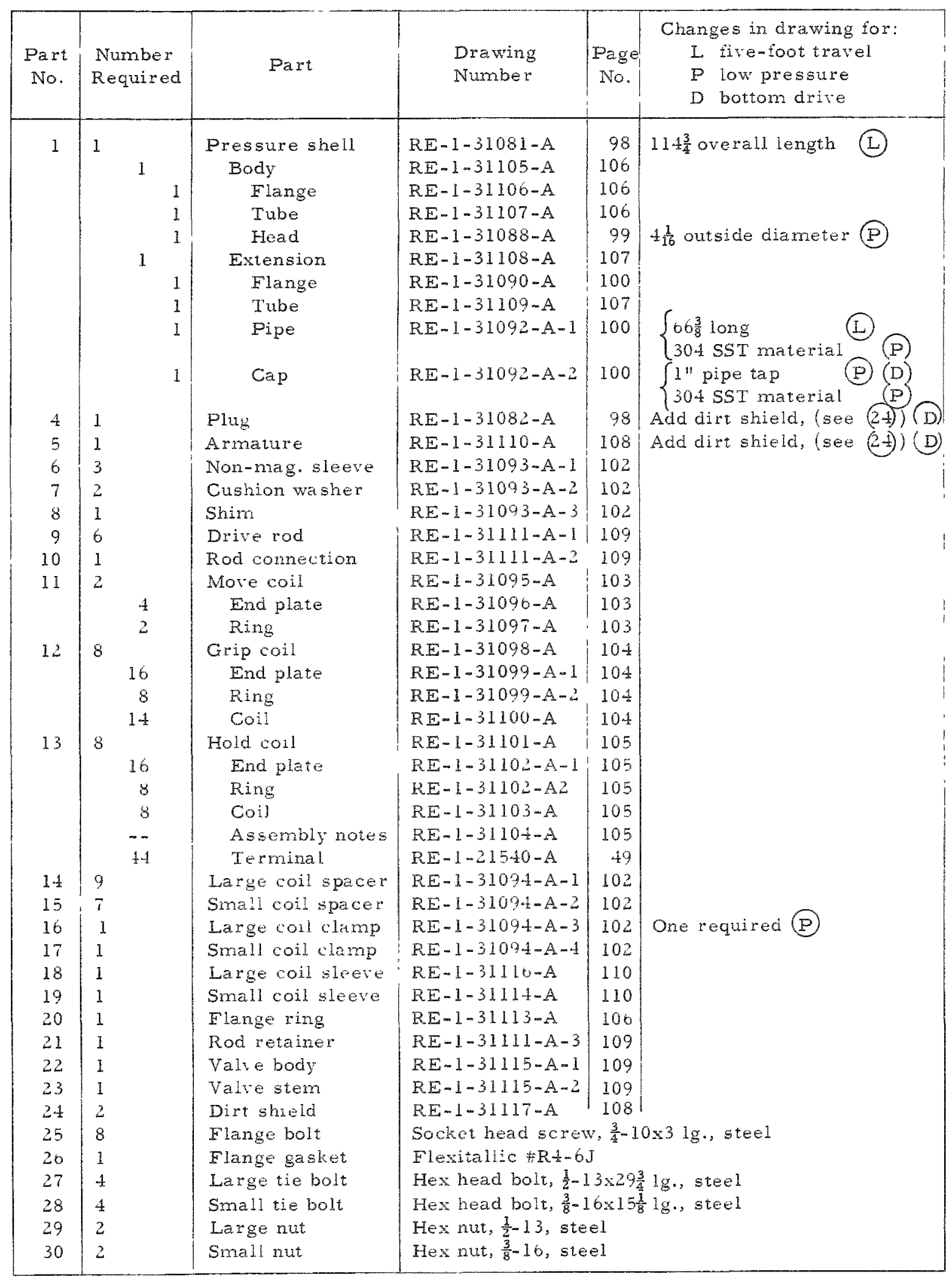



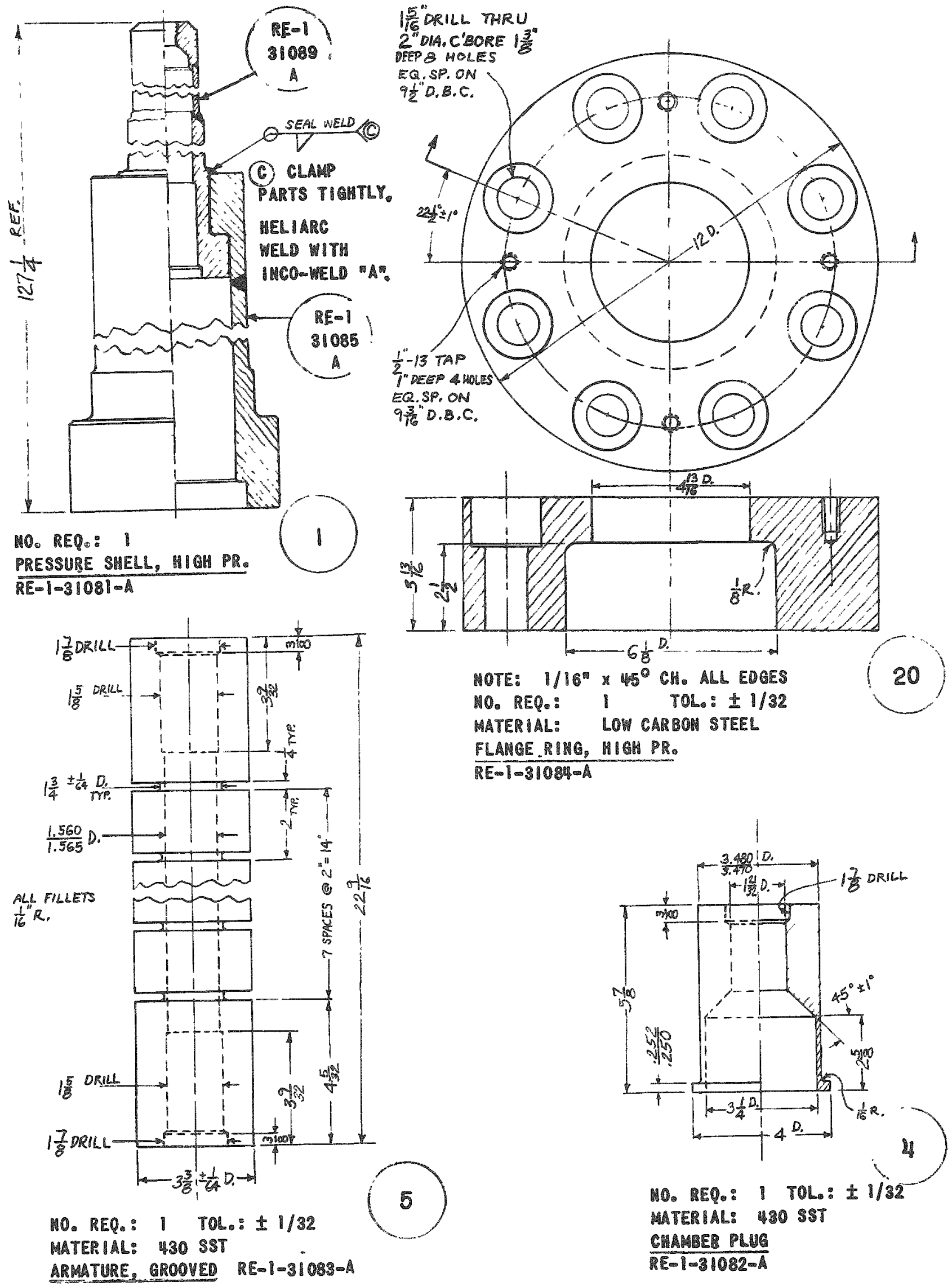

MATERIAL: LOW CARBON STEEL

FLAMGE. RING, MIGH PR. RE- 1-31084-A

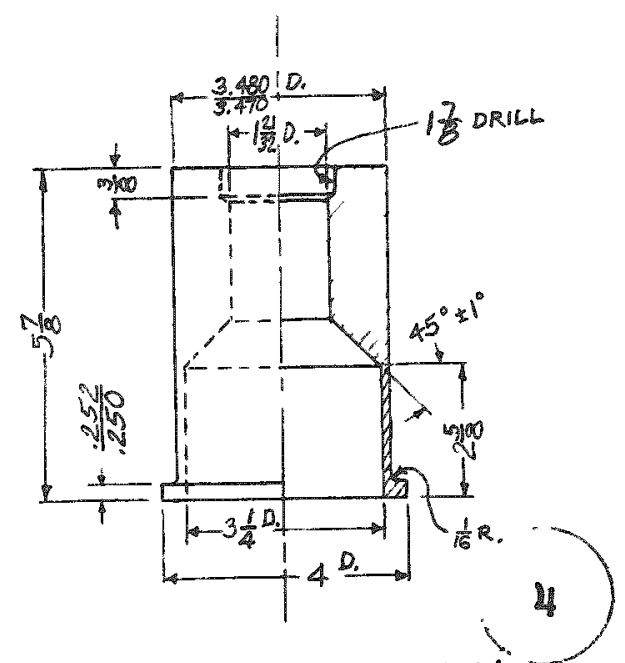

MO. REQ: 1 TOL: $\pm 1 / 32$ MATERIAL: H3O SST COAMABE PLUG ME-1-31082-A 


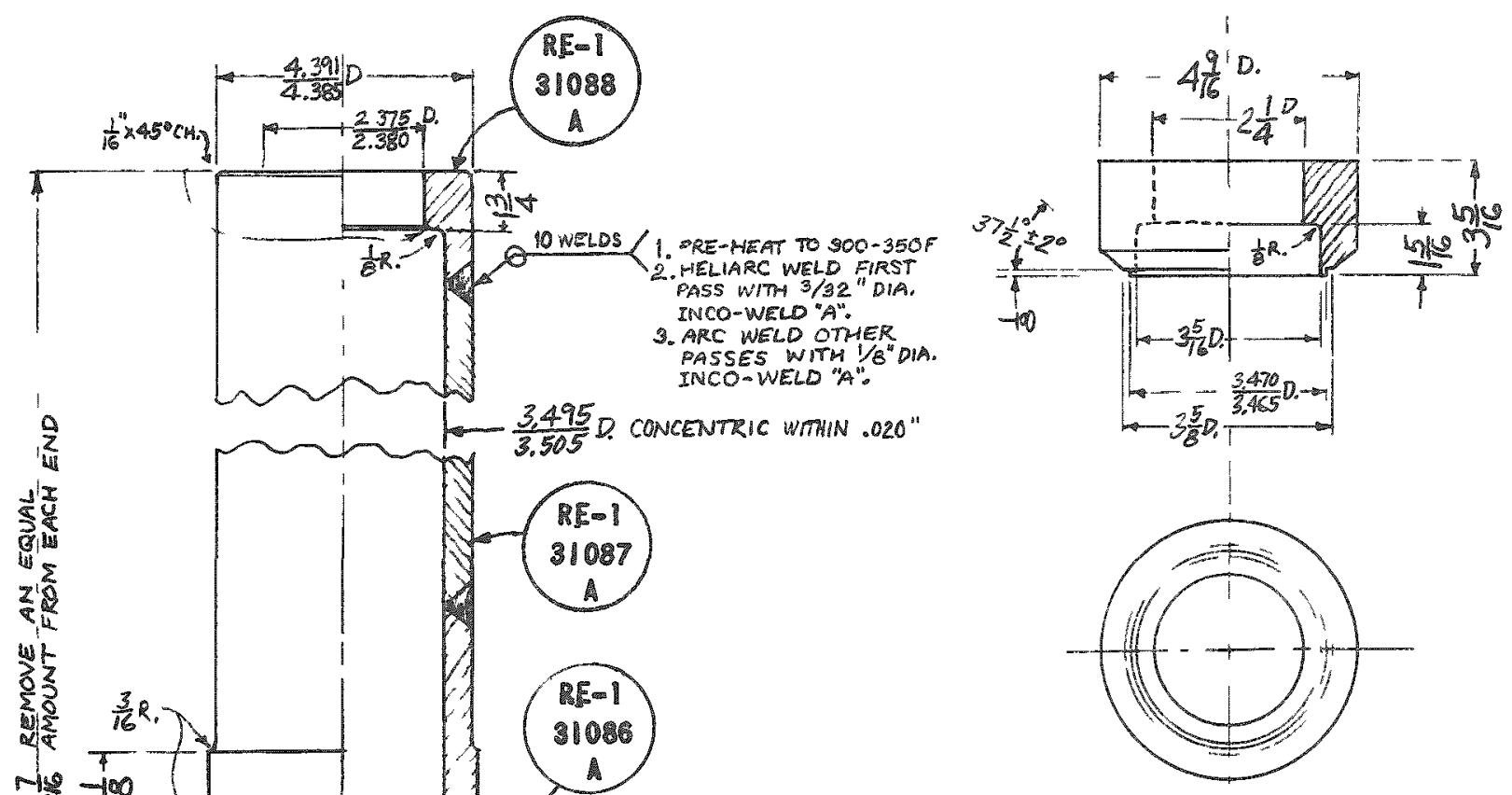

HO. REQ: I TOLO: $\$ 1 / 16$ MATERIAL: 430 SET BOOY HEAD RE-I-3108: $=A$

TOL:

PMESSURE

SHELL POOY HIGe PR.

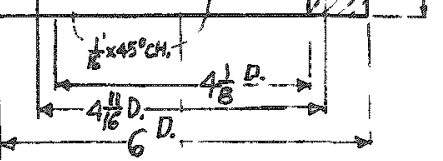
$R E=1-31055=A$

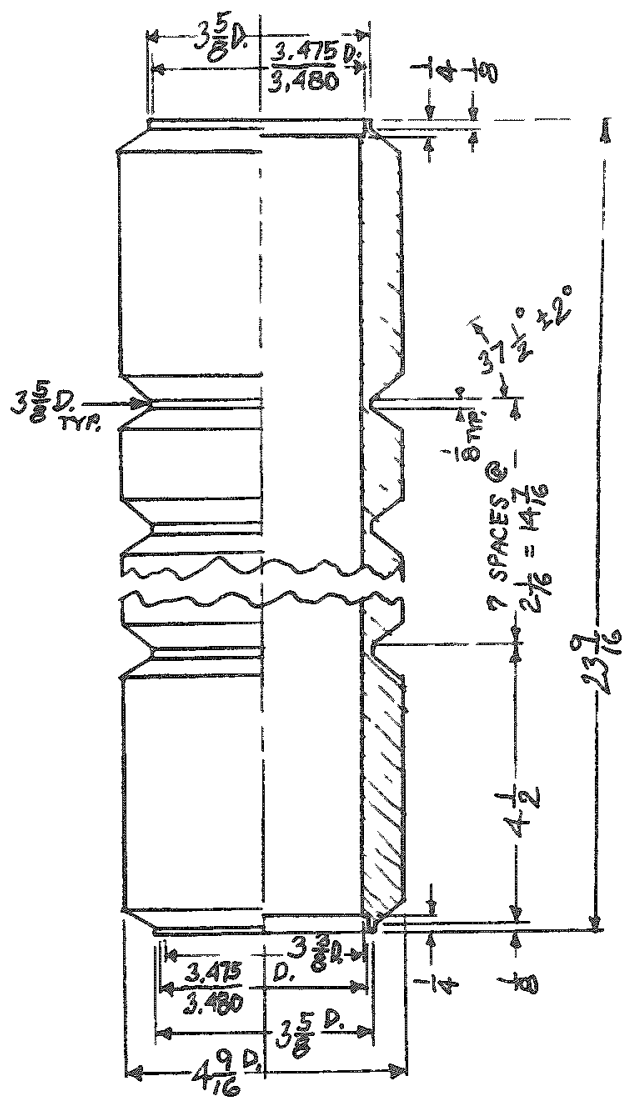

HO. RED: 1

TOL: $\pm 1 / 16$

MATEEIAL:

घ30 SET

DOOY FLAM

IOU PE.

DE-1-31066 $\propto A$

10. EEQ: I TOL: $\pm 1 / 16$

MATERIAL: YYSO SST

BODY TUEE, M MEM PRE. 


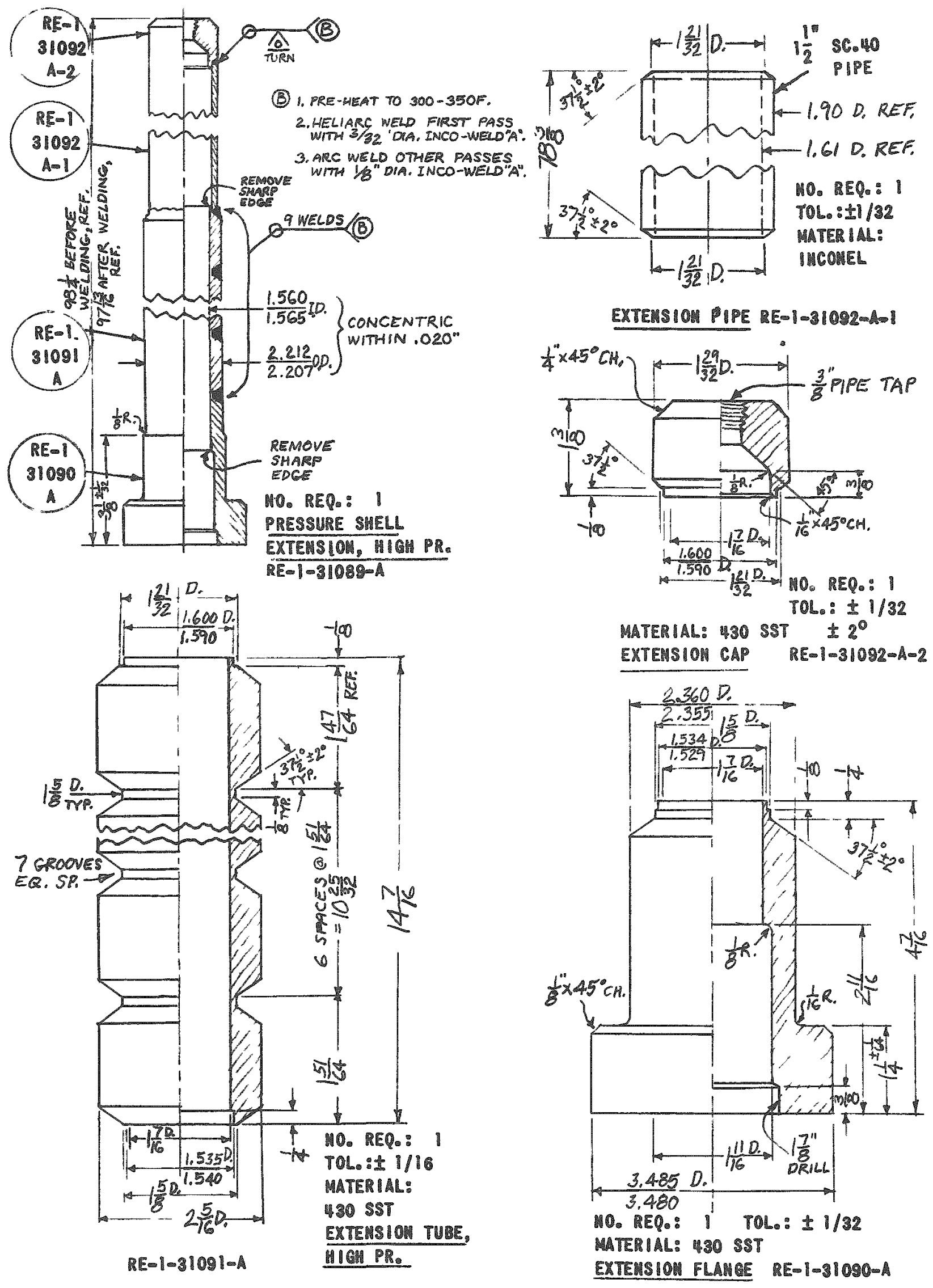




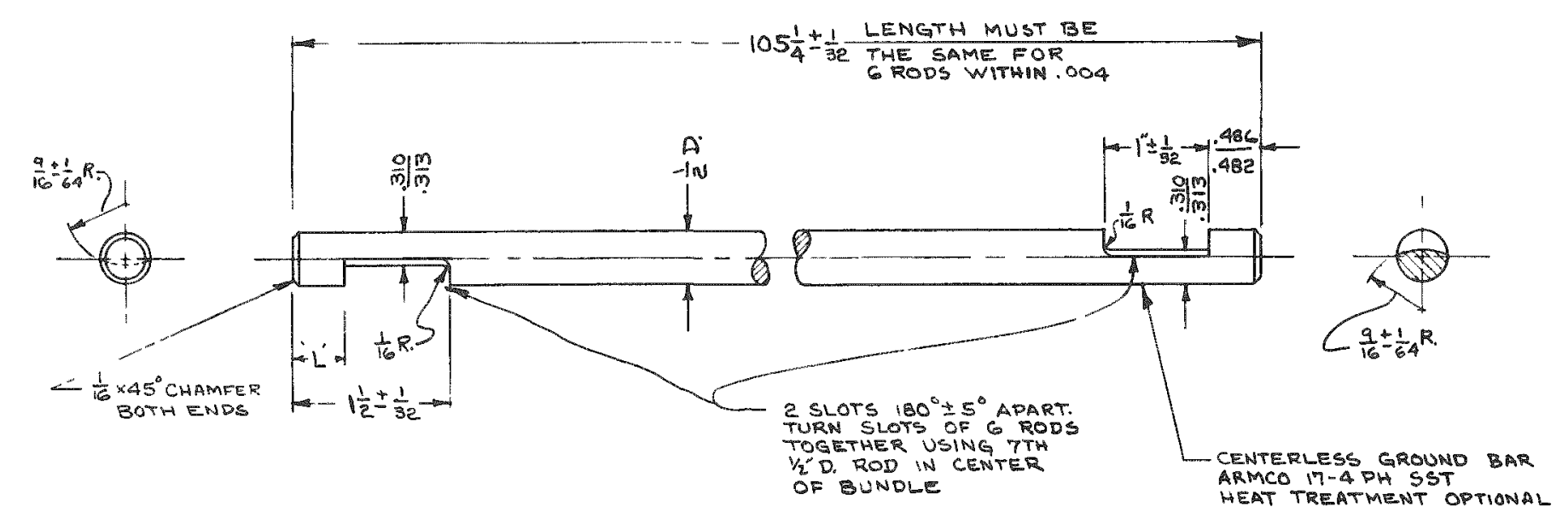

\begin{tabular}{|c|c|c|}
\hline PART & "L" & WQ.REQ' \\
\hline \hline 1 & $\frac{.986}{1482}$ & 5 \\
\hline 2 & 0 & 1 \\
\hline
\end{tabular}

" FILE KNOE FOR LENGTH "L" TO MATGH M/ OR SLIGHTLK BELOW ON ONE END OF

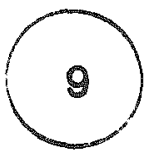

\section{DRIVE ROD HOTCHED RE- - - 18795 - B}
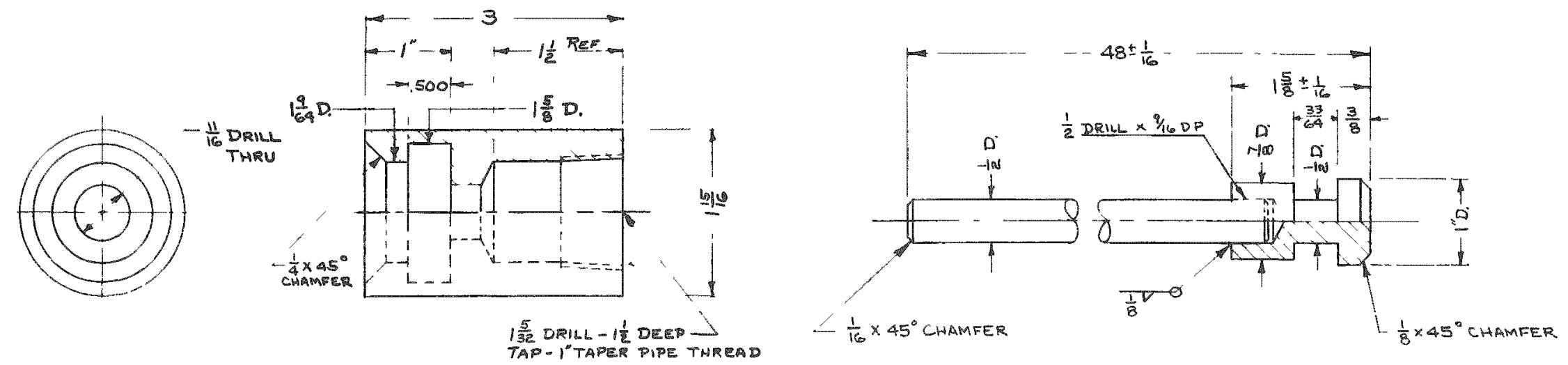

MO. REQ: I

MATERIAL: 304 SST

ROD CONMECTOR
FR. TOLO: $\pm 1 / / 6 \mathrm{C}$

DE. TOLE: \pm .005

RE $=17898$

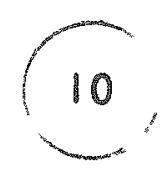

10. REQ: I

MATERIAL: 304 SST

FILLER ROD
TOL: $\pm 1 / 64$
$R E=1-18799-A$ 


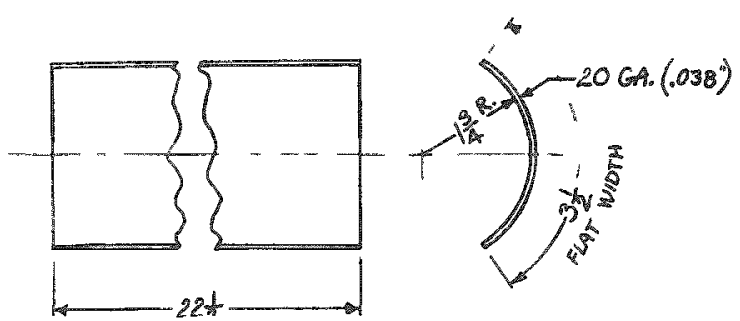

HO. REQ: 3 TOL : $\pm 1 / 16$ MATERIAL: 304 S\$T MON MAGHETIC SLEEVE RE- 1-31093-Á-1
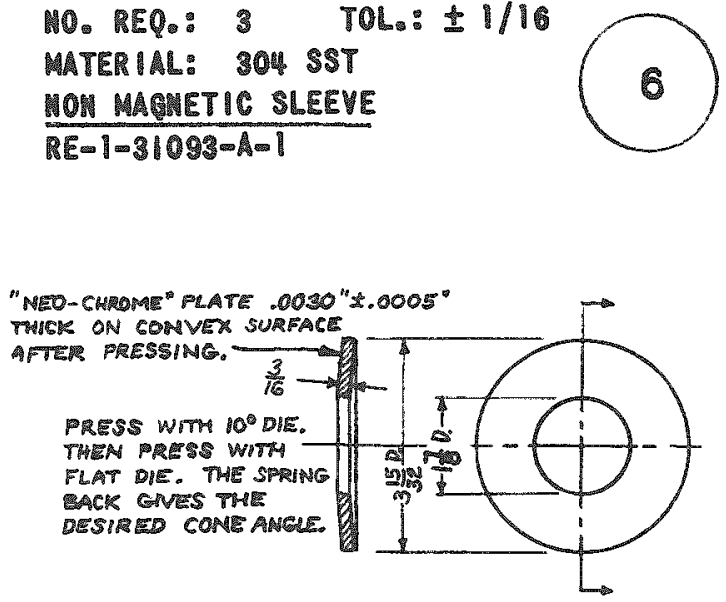

MO. REQ०: 2 TOLe: $\pm 1 / 64$ MATER IAL: 430 SST CUSH IOH HASHER $\overline{R E-1-31093-A-2}$
THLKNASS IS

DETERMINEO SY

TEST TO QIVE

OESIRED STE UENGT

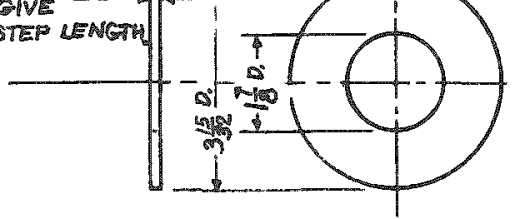

MO. REQ: I TOL: $\pm 1 / 6 \%$ MATER IAL: H3O SST SUIM

$\overline{R E=I-31093 ~}=A-3$

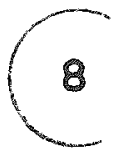

MO. REQ: 10

MATERIAL: HIO OA (.0598")

LOW CARBON STEEL

LARGE COIL SPACER

RE-1-31094-A-1

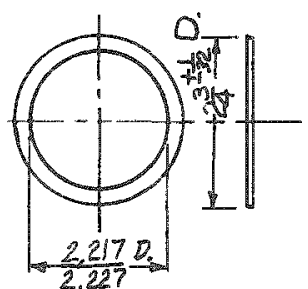

HO. REO: 8

MATERIAL: WIC OA (.0598")

LOV CARBOW STEEL

SMALL COIL SPACER

RE-1-31094-Aि-2
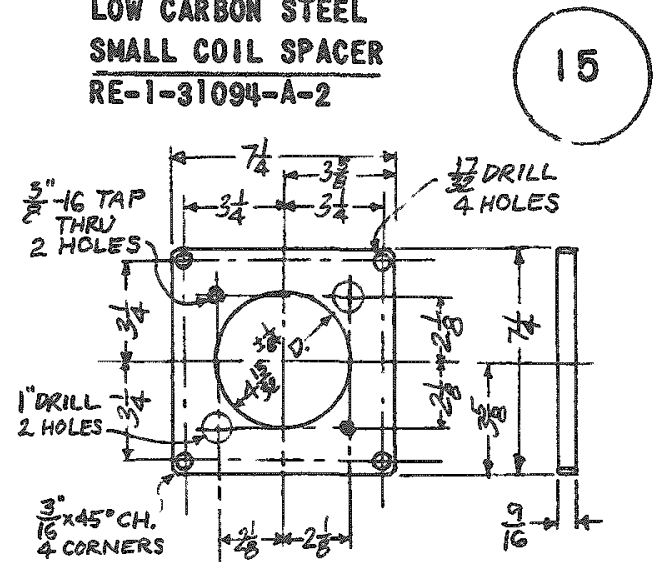

MO. REQ: I TOL: $1 / 1 / 32$

MATERIAL: LOW CARBON STEEL

LARGE COIL CLAMP

ME I-31094-A-3

NOTE:

CADMIUM PLATE

$.0008^{m} \pm .003^{m}$

STEEL

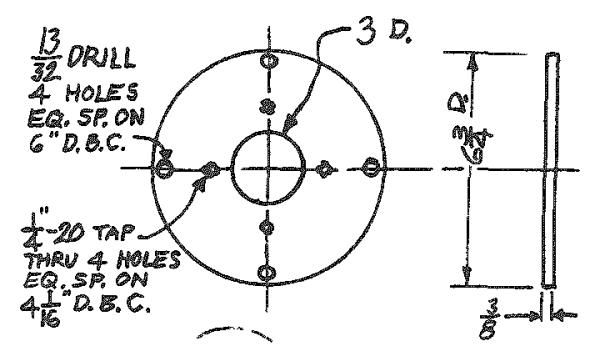

LOM CARBOSE

SMALL COIL CLAMP

RE-1-31094-A=4

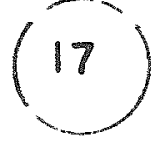

STEEL PARTS 


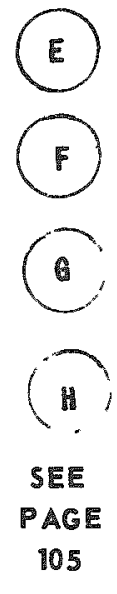

SPEC:

1290 TURAS

12.0 OHMS AT T7 $7 \mathrm{~F}^{\circ}$
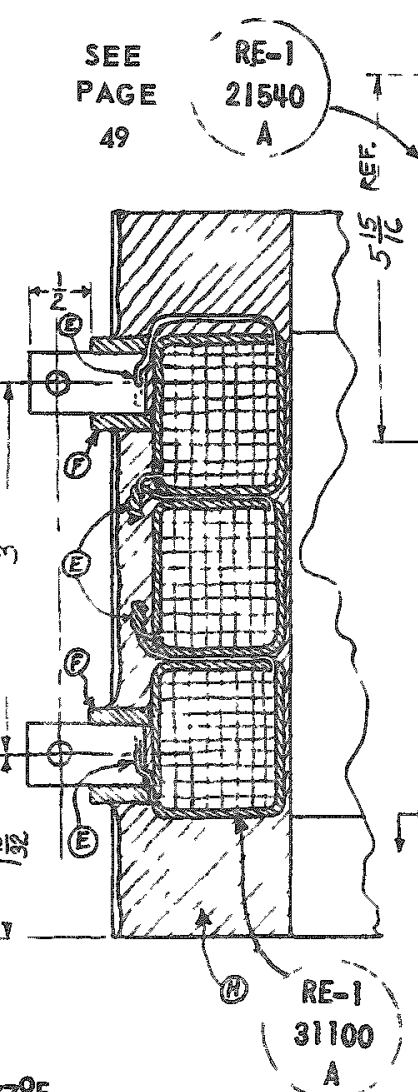

HO. REQ: 2, TOLE: $1 / 132$.

MOVE COIL, POTTED REOI-31095-A

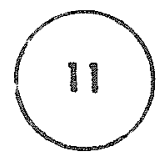

(6) $\#-$

$m$

$=\frac{\mid 1 \backslash 1}{1} \quad 1$
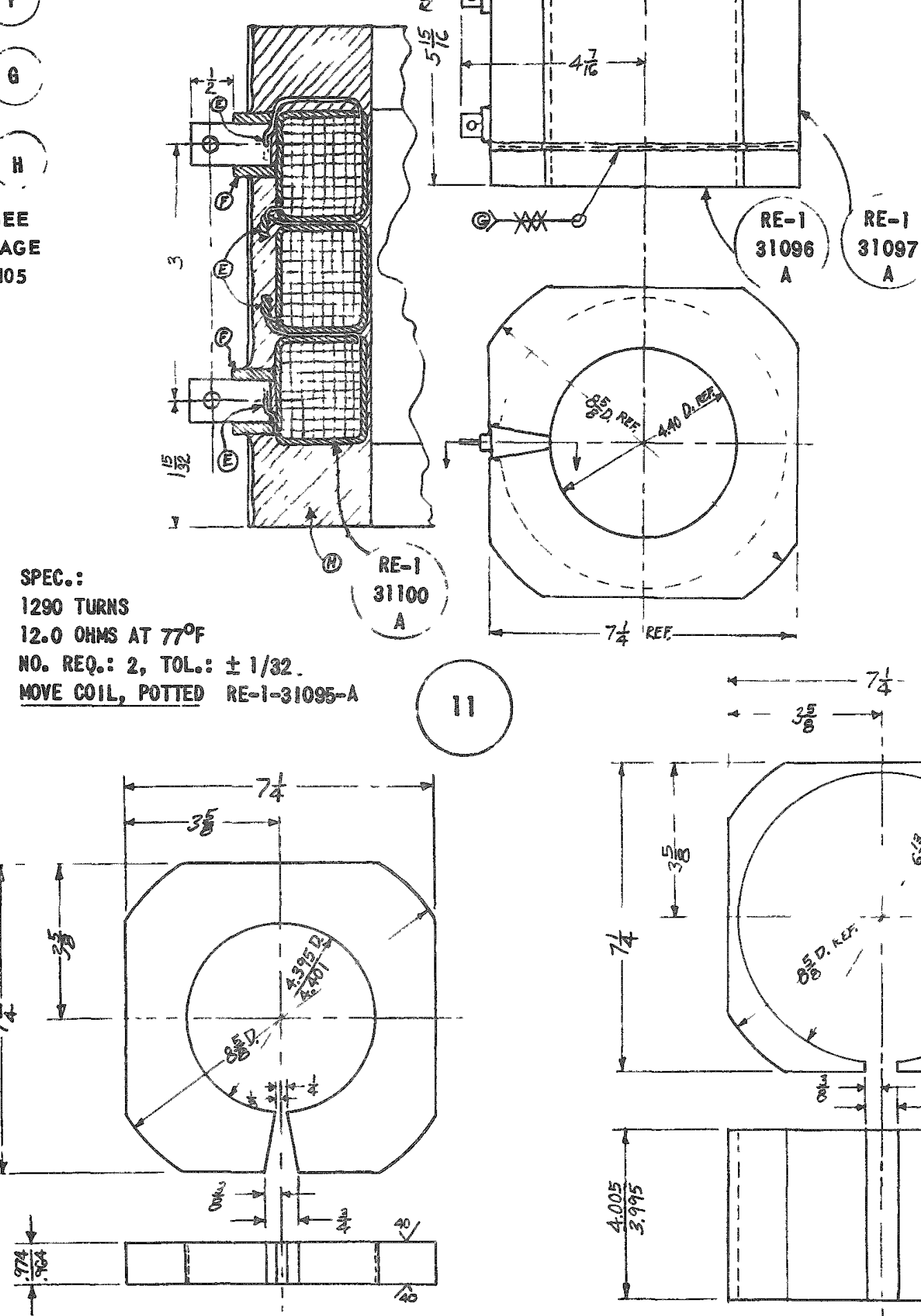

MO. REQ: 4 TOL: TI/P2

MATERIAL: LOW CARROS STEEL

MOVE COL EMD PLAT REOH=31096-A

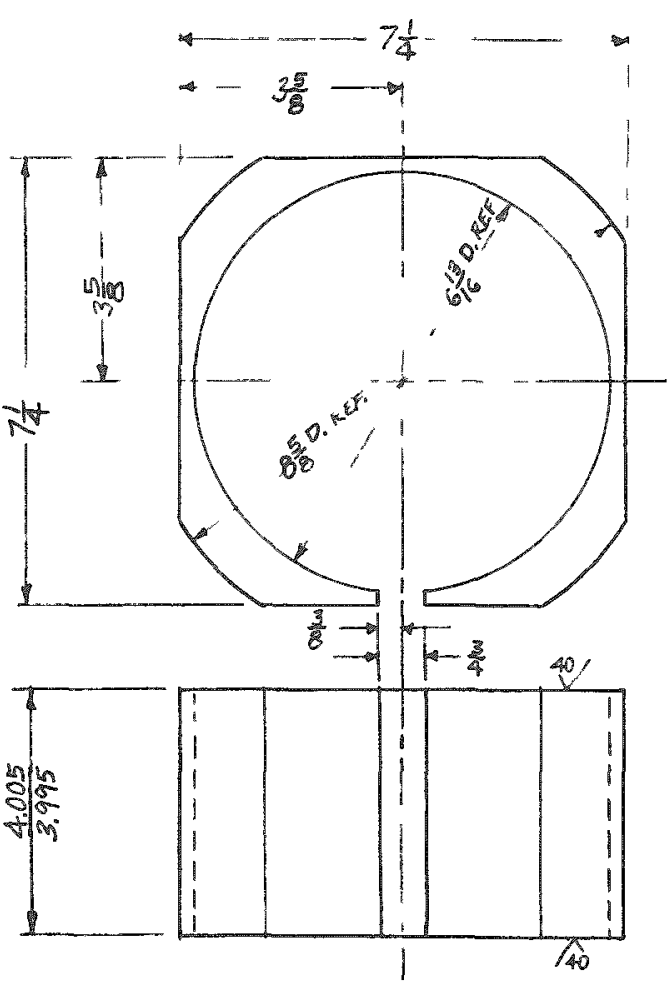

W0. REQ: 2, TOL: $\pm 1 / 32$, MATERIAL:

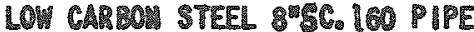
MOVE COLL RING RE-I-31097-A 


$$
\text { SEE PAGE } 105
$$

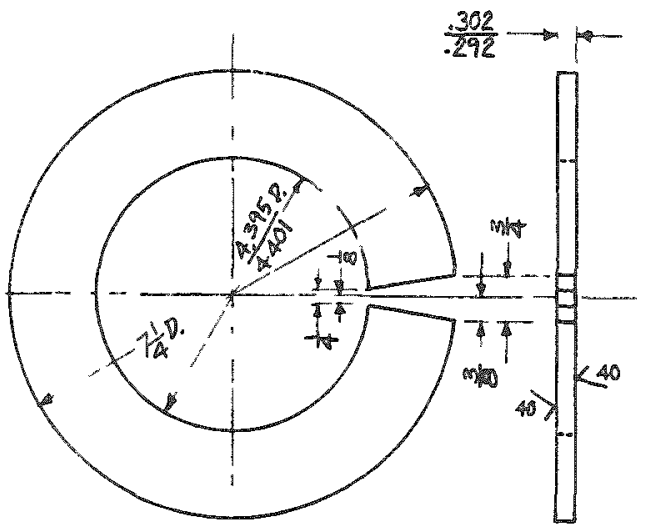

HO. REQ: 16. TOL: $\pm 1 / 32$ MATERIAL: LOW CARPON STEEL GR IP CQIL EMD PLATE RE=|-\$1098 A- I

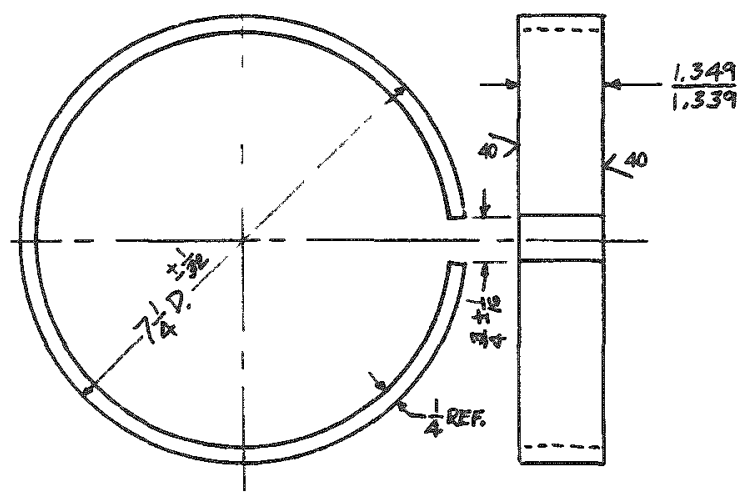

MO. REQ:

MATERIAL: LOW GAROW STEEL

GIP CQIL RIME

RE-1 - $31028-A-2$

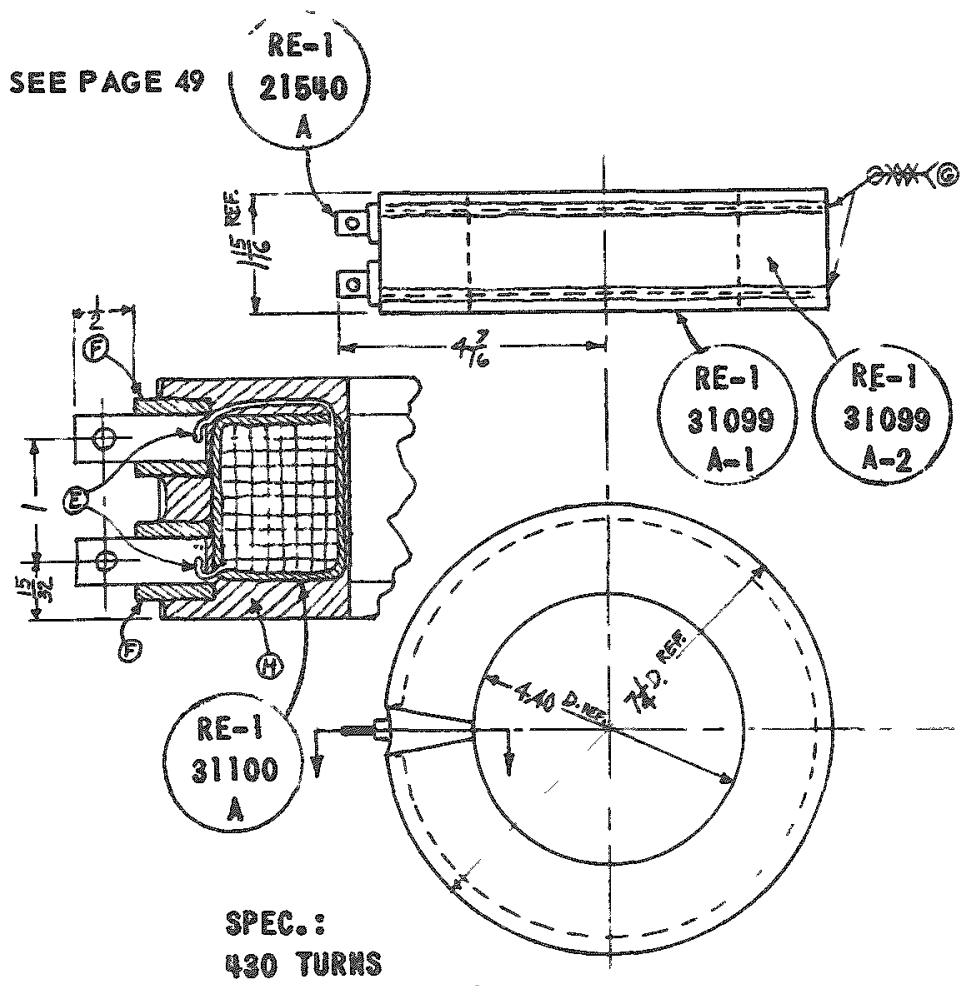

430 TURหม

W. O OMMS AT $77^{\circ} \mathrm{F}$

HO. REQS: 8 . TOL: $\pm 1 / 32$

GRIP COLL, POTTED RE-I-31098-A

12

430 TUINS OF

\#/8 DOUSLE GLASS-

SILICONE MAGNET WIRE

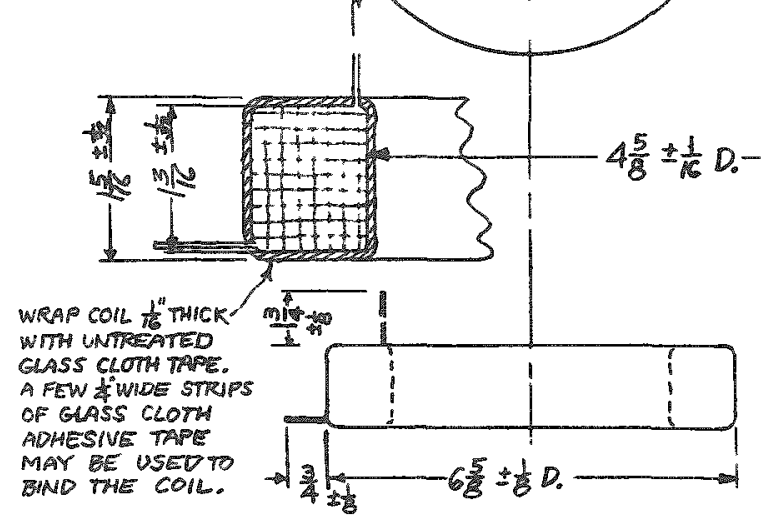

MO. REQ⿻: IH

aR IP COLL

RE=1-\$1100 $=$ 


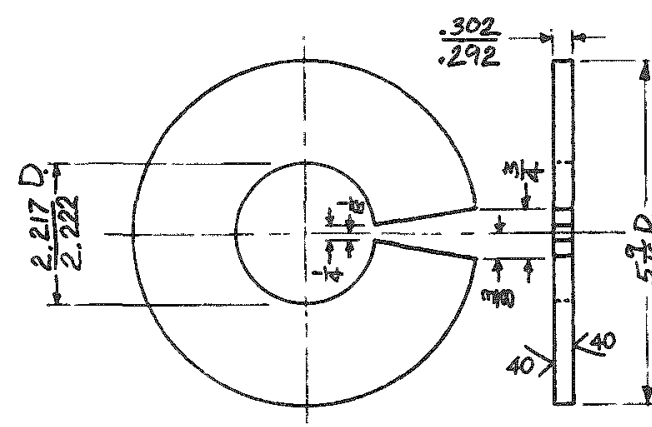

HO. REQ⿻: 16, TOLO: $\pm 1 / 32$ MATERIAL: LOW CARBON STEEL HOLO COIL END PLATE $R[-|-3| 102-A=1$

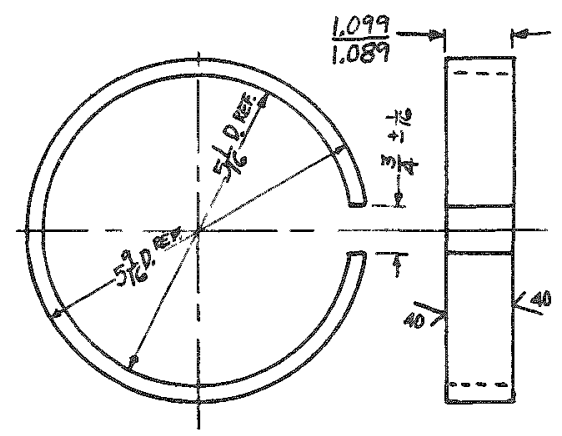

MO. REQ: 8 , TOL: $\pm 1 / 32$ MATERIAL: LOW CARBON STEEL HOLO CQLL RIMG $\overline{R E=|=3| 102-A=2}$

Coil Assembly Notes

E. Silver solder the wire connection with "Easy wFlo.

F. Wrap the terminals and the long lead wire $1 / 8^{\text {" }}$ thick with $3 / 4$ " wide untreated glass cloth tape. Hold the end of the tape with a $1 / 8^{n}$ wide strip of glass cloth adhesive tape.

G. Clamp the parts in the welding jig and seam weld by fusing the base metal (no filler rod). The weld is required to be strong enough to hold the parts together during ordinary handling and to be leak-proof enough to hold the potting material while it is liquid.

11. Clamp the welded assembly in the teflon mold a nd vacuum impregnate with epoxy resin prepared as follows: to shell Epon Resin 815 add $10 \%$ by weight of MMM Cardelite N.C. 513; heat mixture to $140^{\circ} \mathrm{F}$ : to mixture add $14 \%$ by weight of shell Epon Curing Agent CL (heated until melted) stir well; use inmediately. Keep the filled mold at room temperature for 12 hours to allow the resin to ge1. place filled mold in $180^{\circ} \mathrm{F}$ to $200^{\circ} \mathrm{F}$ furnace for two (2) hours.

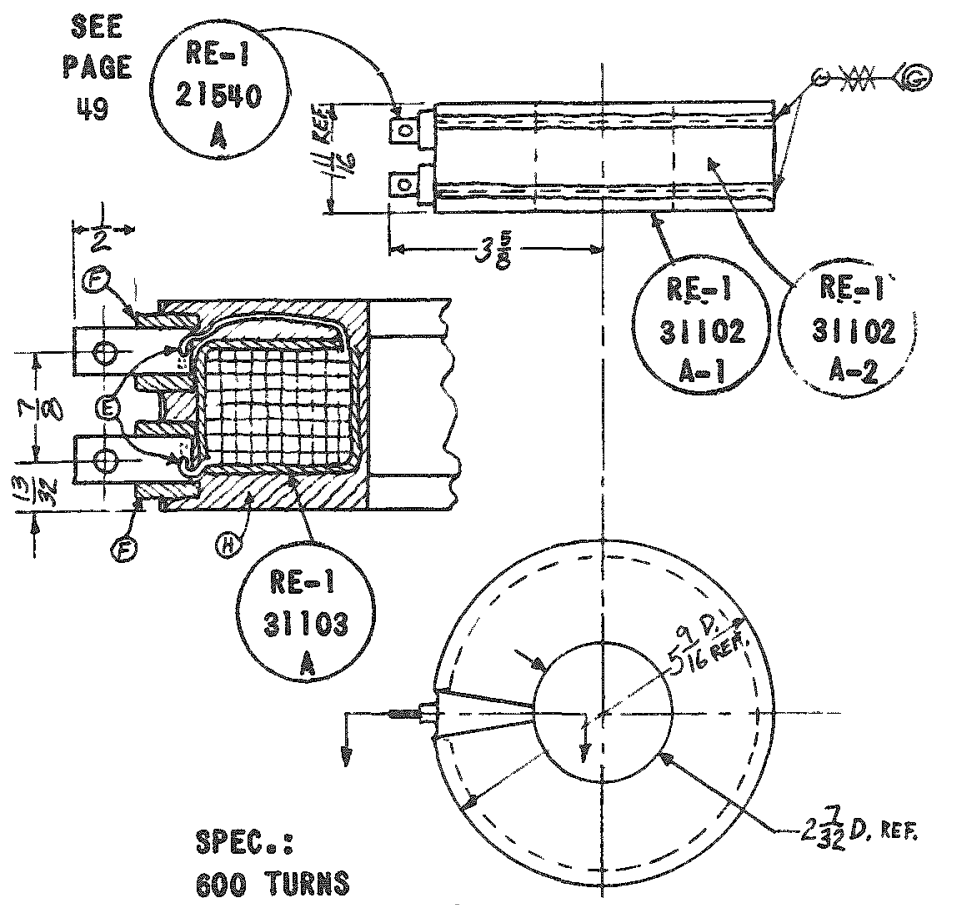

5.8 OUMS AT $77^{\circ} \mathrm{F}$

NO. $\mathrm{REQ},:$ : TOL: $\pm 1 / 32$ HOLO COLL, POTTED RE-I-3IIOI-A
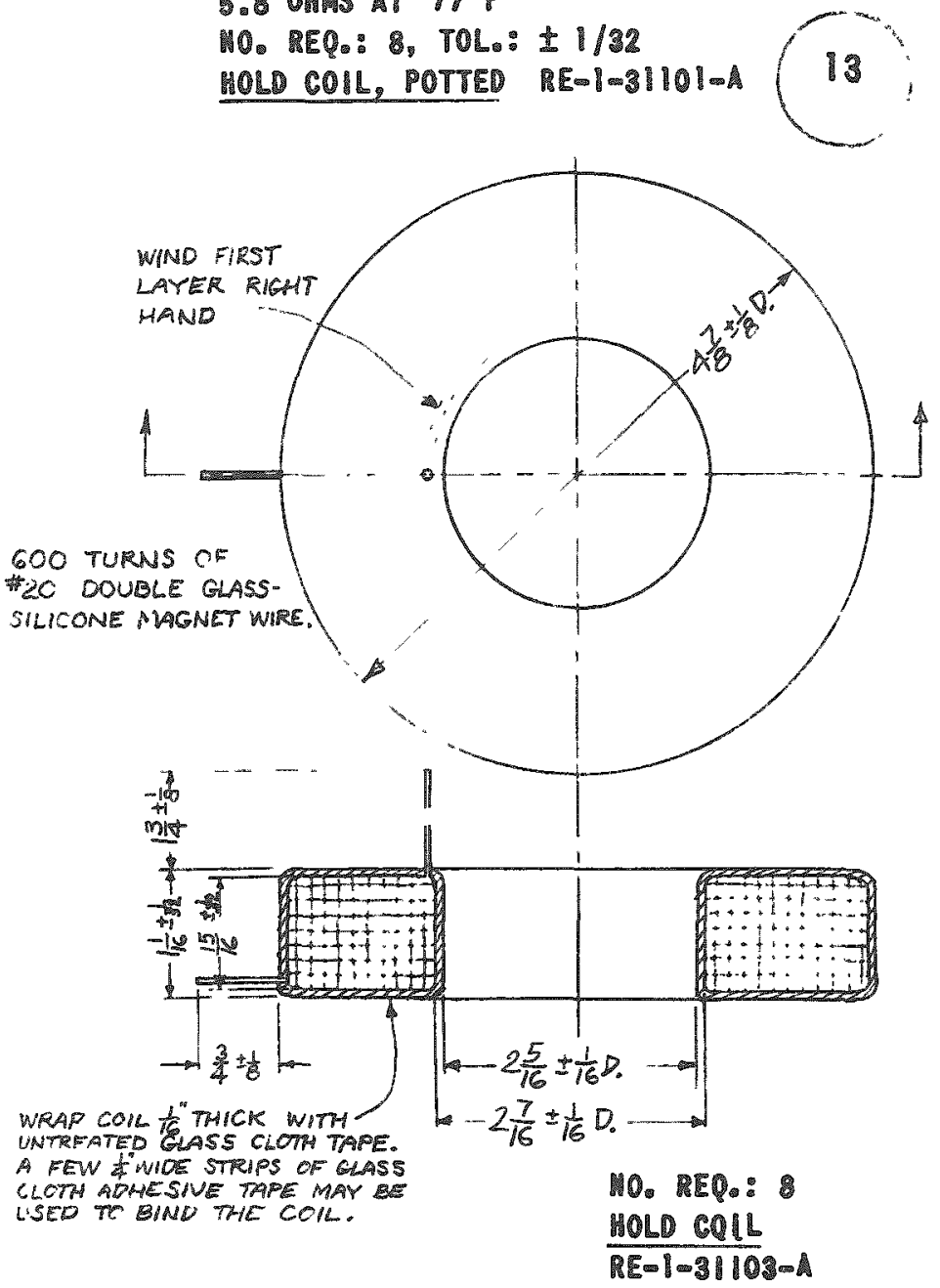


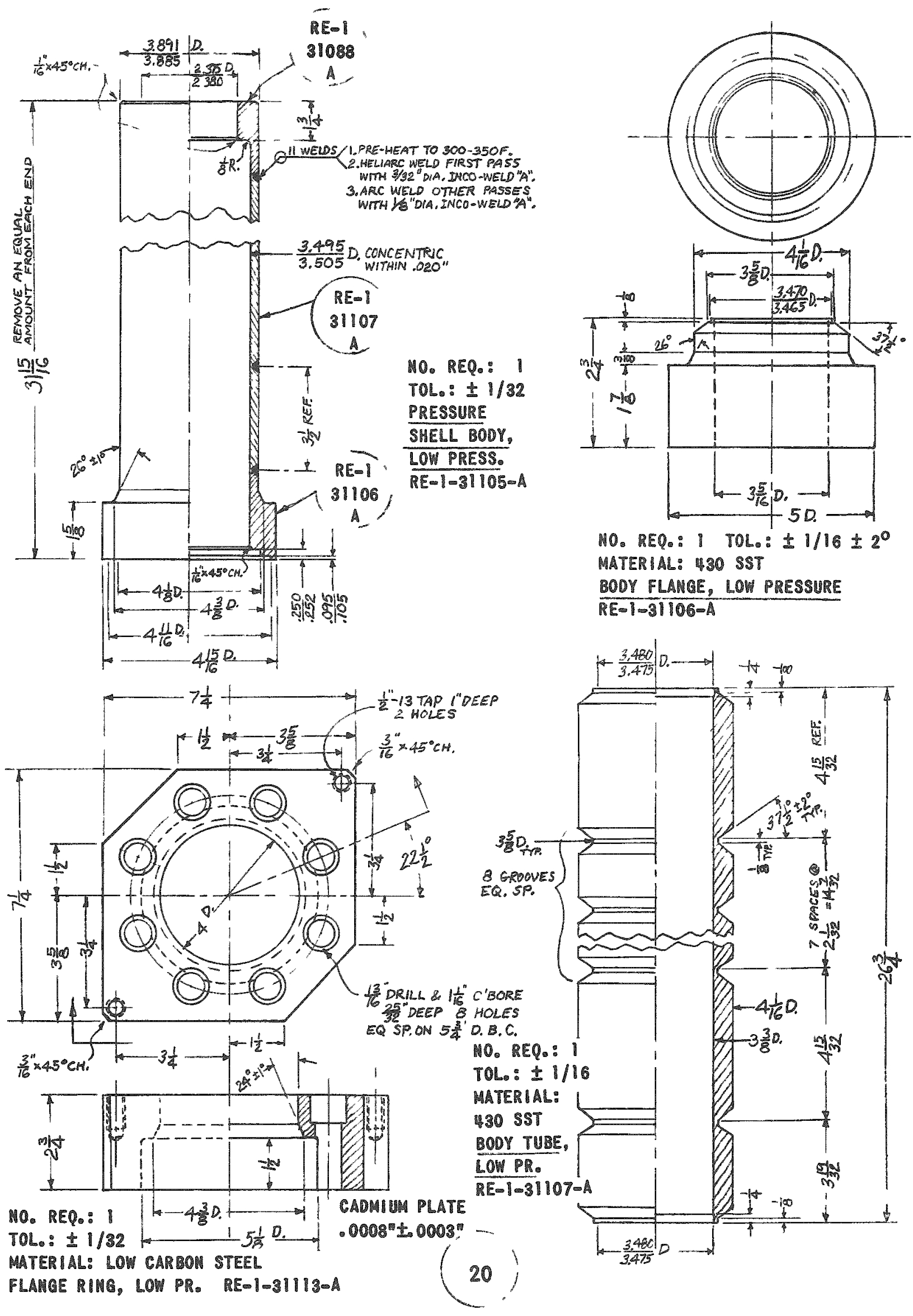




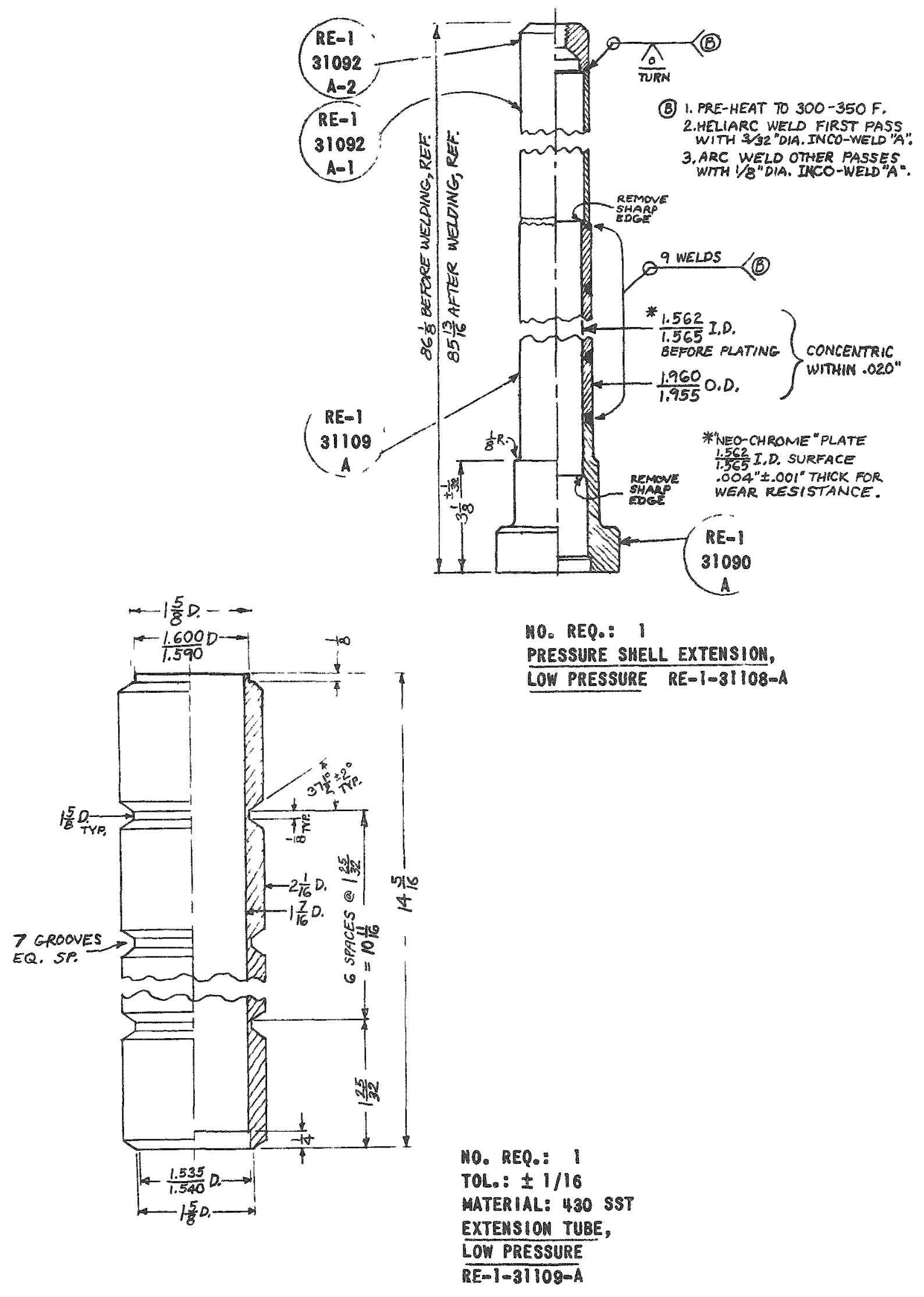




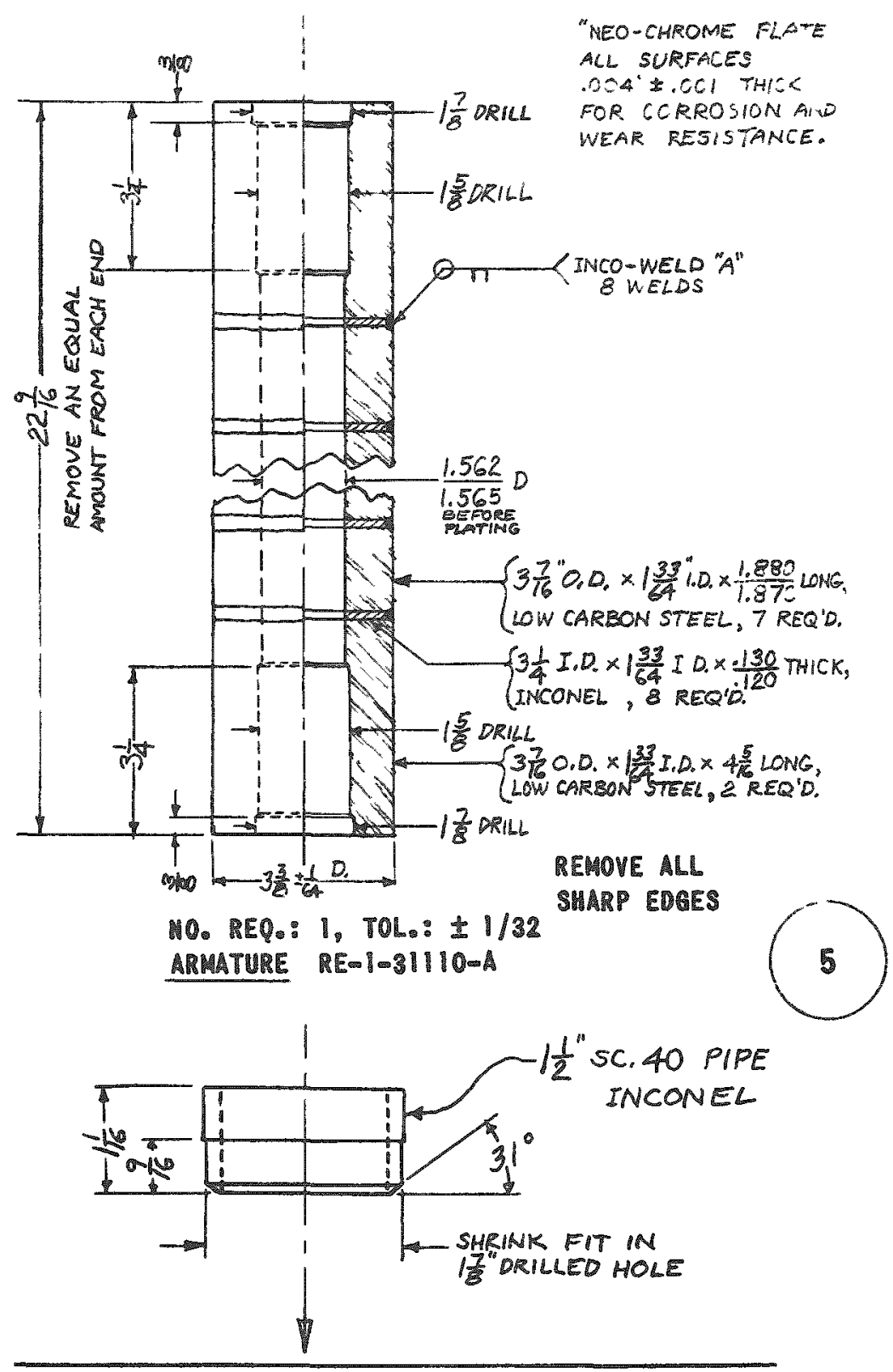

TURN AFTER SHRINK FIT ASSEMBLY

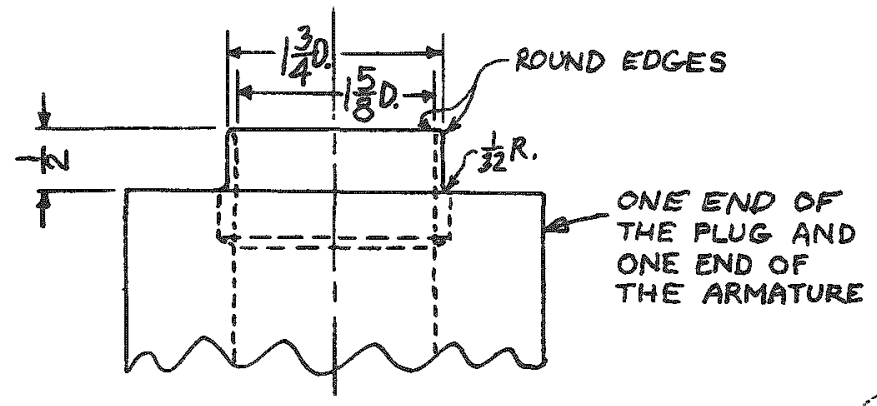

10. MEQ: 2. TOL: $\pm 1 / 64$ DIRT SUITL RE- I-3IIT-A 


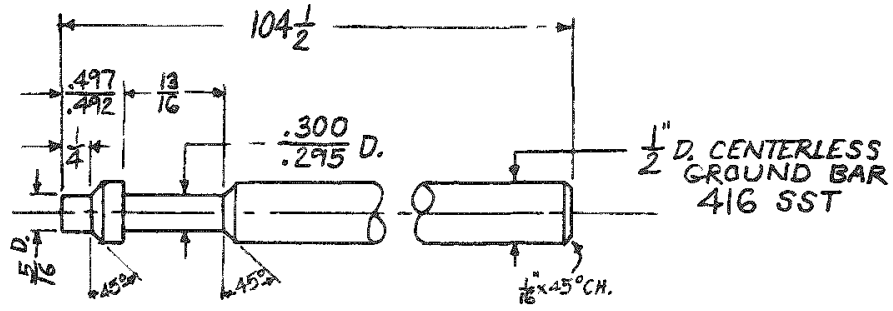

WO. REQ: 6

TOL.: $\pm 1 / 32$

DRIVE MOD

RE-|-3ाT| -A=|
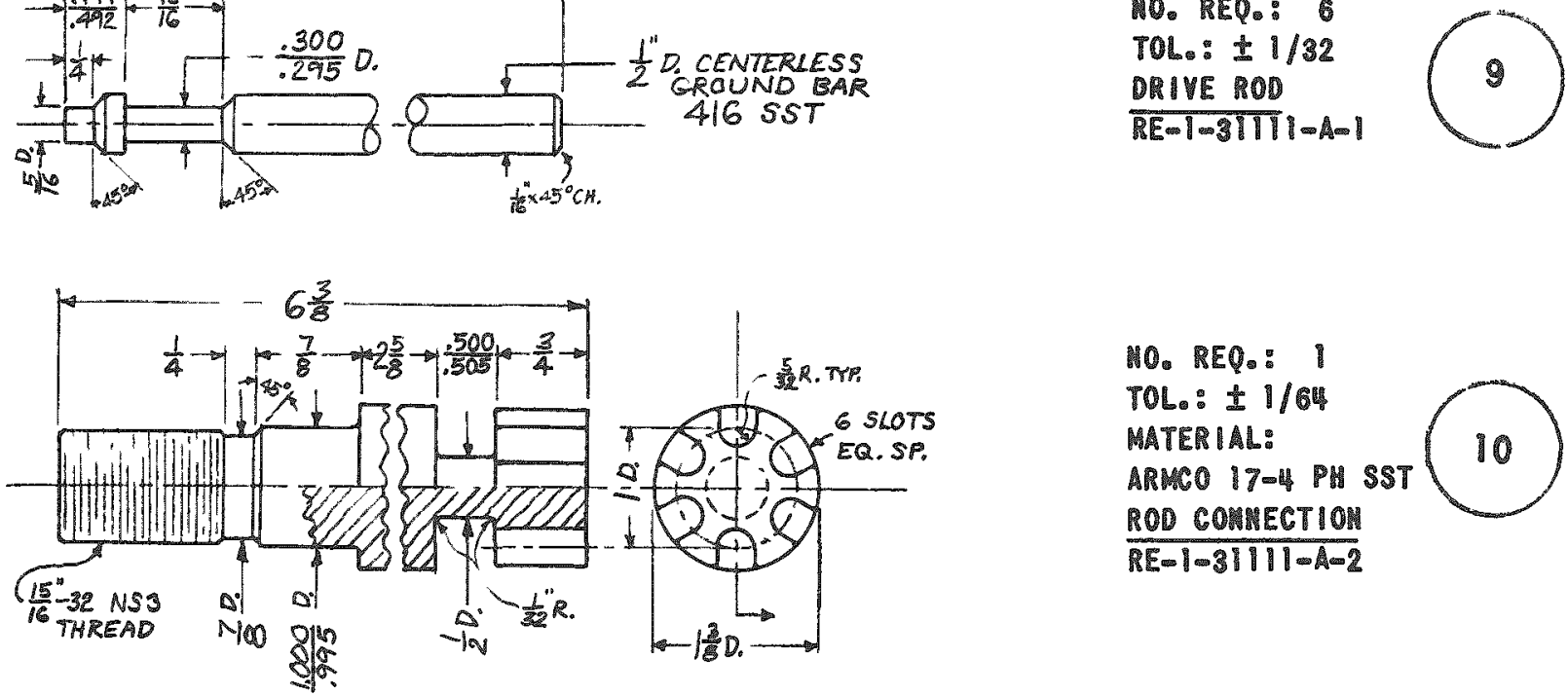

HO. REQ: 1 TOL: $\pm 1 / 64$ MATER IAL: ARMCO 17-4 PH SST ROD COMRECTION $\overline{R E-\mid-3}||||-A-2$

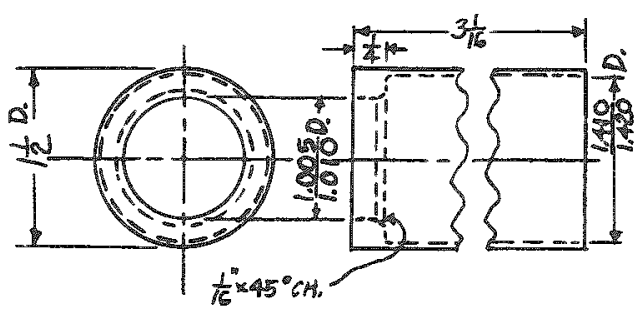

MO. REO: I

TOL: $\pm 1 / 32$ MATERIAL: 304 SST ROO RETAIMER $\overline{R E-|-3 !|||=A-3}$

HO. REQ: I TOL. $\pm 1 / 32$ MATERIAL: ALUMIMUM BRONZE VALYE BOOY

1ㅁDRLE

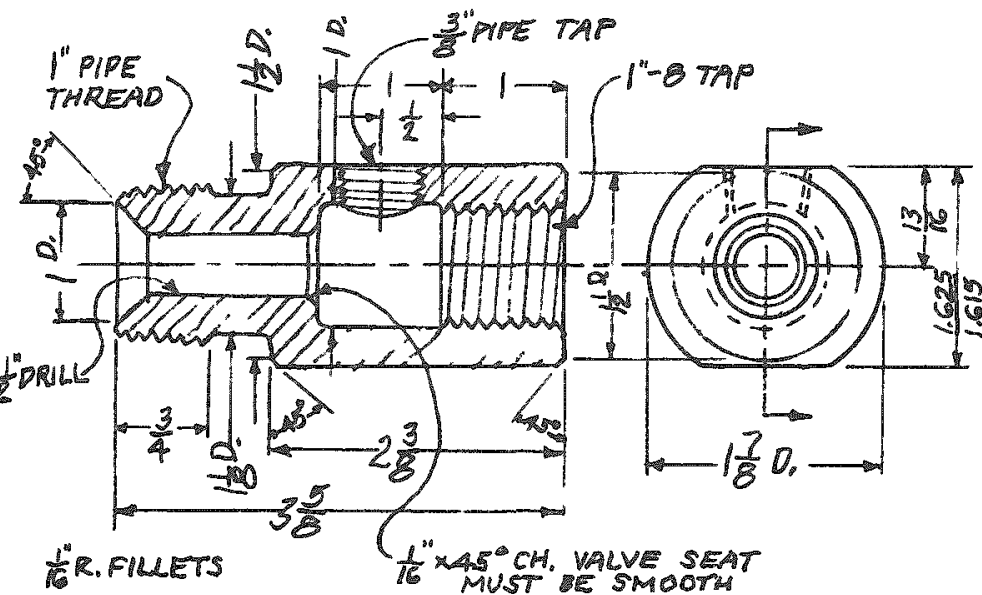

$\overline{R E=\mid-31115=A-1}$
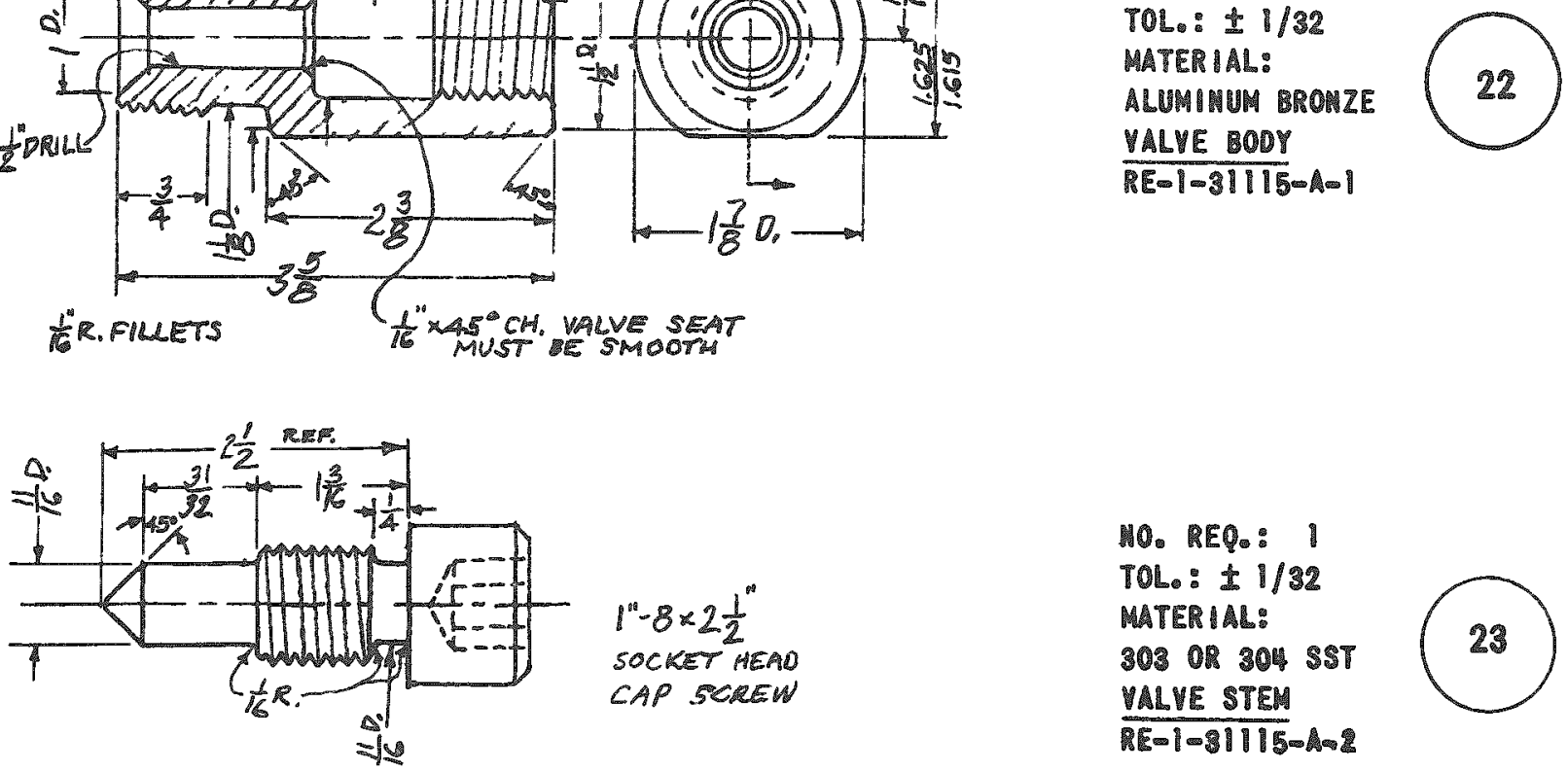

$1^{\prime \prime}-8 \times 2 \frac{1}{2}^{\prime \prime}$

SOCKET HEAD

CAP SCREW
MO. REO: 1

TOLO: $\pm 1 / 32$

MATERIAL:

303 OR 304 SST

VALVE STEM

RE్|-31115-A-2 


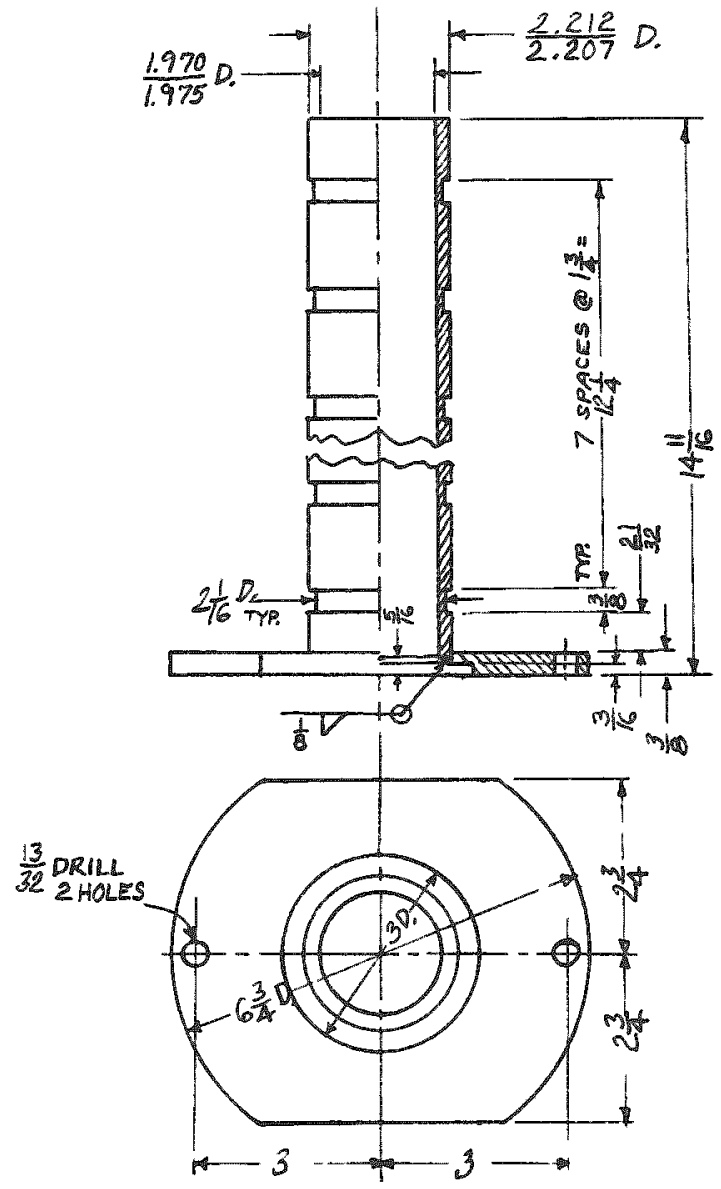

CADMIUM PLATE $.0008^{\circ} \pm .0003^{m}$

MO. REQS: I TOL: $\pm 1 / 32$ MATERIAL: LOV GARBOH STEEL SMALL COLL SLEEVE RE-1-31114-A

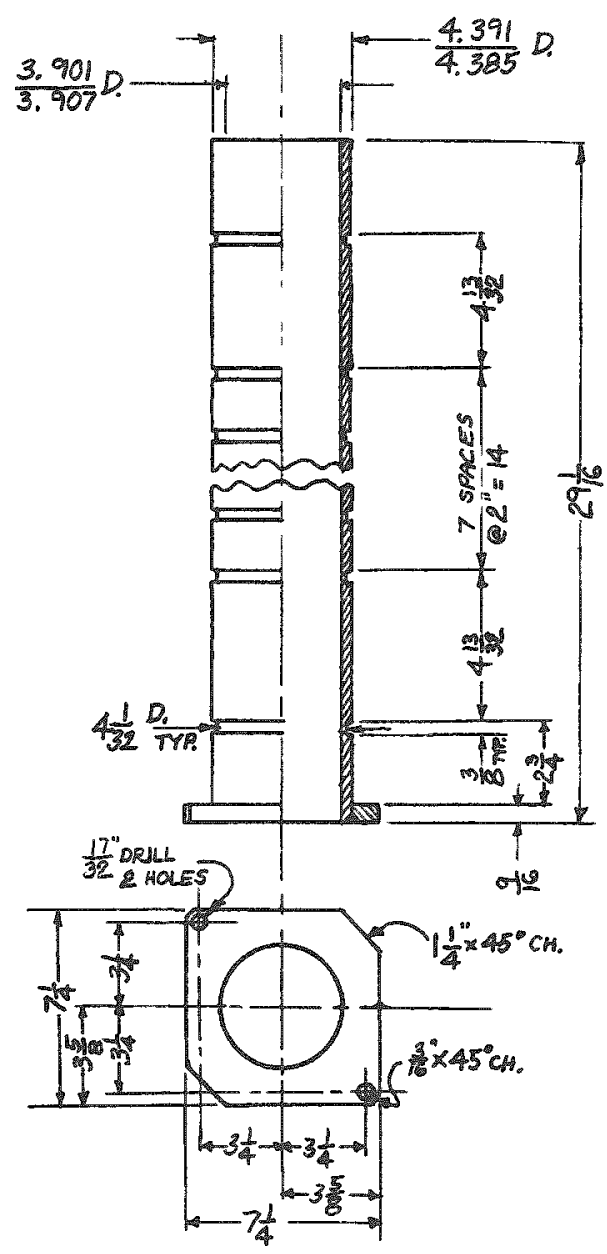

CAOMIUM PLATE $.0008^{\text {t. }} 0003^{\text {m }}$

HO. REP: 1 TOLE: $\pm 1 / 32$ MATER IAL: LOW CARBON STEEL LARGE COIL SLEEVE RE= I-3!II6-A 


\section{APPENDIX D}

\section{POSITION INDICATORS}

Position indicators used with the magnetic jack are of the electromagnetic, stationary-coil type. This type is used because it avoids, as does the magnetic jack, the use of shaft seals and mechanisms near the reactor which might require maintenance. Basically, these position indicators consist of a coil that fits over a nonmagnetic pipe which is the portion of the pressure shell which is used for containing the drive rod as it moves through the jack. Since the drive rod is magnetic, the length of rod in the coil effects the impedance of the coil. Measuring the impedance gives the position of the rod.

The impedance-measuring system which seems to be most attractive involves the measuring of the voltage across the coil, which is supplied with a 60-cycle constant (or nearly constant) current. This voltage increases by a factor of eleven when the rod is inserted in the coil. A bridge circuit is not used because it is more complicated and because of the possibility of loose connections overloading the meter.

For this size of device (a cluster of six $\frac{1}{2}$-in. diameter rods in a $1 \frac{1}{2}$-in. standard pipe), a coil of \#18 wire with 200 turns per inch of coil length has about the right amount of copper. Less copper has too much resistance and more copper has too much self-inductance.

The coil shown on page 113 is used for all of the position indicators described here. They are assembled to suit the particular application. The first coil of an assembly is supplied with a slightly higher voltage than the rest of the coils, to compensate for its being at the end. Closer readings and a smaller temperature error are obtained by using a larger number of shorter coils; however, there is little improvement below a two-inch spacing.

The table on page 112 describes six types of position indicators in the order of their simplicity. 
COMPARATIVE DESCRIPTION OF SIX TYPES OF POSITION INDICATORS

\begin{tabular}{|c|c|c|c|c|c|c|}
\hline TYPE & light bulb & light and meter & automatzc meter & linear scale meter & decade switch & automatic digital \\
\hline BUILT AND TESTED & Jan. 1955; June 1959 & June 1957 & March 1958 & April 1958 & Feb. 1959 & \\
\hline COARSE INDICATION & light bulbs & light bulbs & bar indicator & $207^{\circ}$ linear scale & calibrated scale & digital display \\
\hline $\begin{array}{l}\text { COARSE READING } \\
\text { PROCEDURE }\end{array}$ & $\begin{array}{l}\text { position is read on scale } \\
\text { at dim light or between } \\
\text { bright lights and dark } \\
\text { lights }\end{array}$ & $\begin{array}{l}\text { position is read } \\
\text { on scale at dim } \\
\text { light or between } \\
\text { bright lights and } \\
\text { dark lights }\end{array}$ & $\begin{array}{l}\text { position is } \\
\text { indicated by } \\
\text { length of red } \\
\text { line }\end{array}$ & $\begin{array}{l}\text { position is read } \\
\text { directly in inches } \\
\text { on meter scale }\end{array}$ & $\begin{array}{l}\text { position is read } \\
\text { directly in in- } \\
\text { ches on meter } \\
\text { scale }\end{array}$ & $\begin{array}{l}\text { numbers are } \\
\text { read }\end{array}$ \\
\hline $\begin{array}{l}\text { COIL SWITCHING FOR } \\
\text { CLOSE INDICATION }\end{array}$ & manual selector switch & $\begin{array}{l}\text { manual selector } \\
\text { switch }\end{array}$ & $\begin{array}{l}\text { automatic se- } \\
\text { lector switch }\end{array}$ & $\begin{array}{l}\text { manual selector } \\
\text { switch }\end{array}$ & $\begin{array}{l}\text { two manual se- } \\
\text { lector switches }\end{array}$ & $\begin{array}{l}\text { two automatic } \\
\text { selector } \\
\text { switches }\end{array}$ \\
\hline CLOSE INDICATION & meter and graph & $\begin{array}{l}\text { meter with cali- } \\
\text { brated dial }\end{array}$ & $\begin{array}{l}\text { meter with cal- } \\
\text { ibrated shifting } \\
\text { dial }\end{array}$ & meter with graph & $\begin{array}{l}\text { meter with cal- } \\
\text { ibrated decade } \\
\text { dial }\end{array}$ & $\begin{array}{l}\text { multi-contact } \\
\text { meter-relay with } \\
\text { digital display }\end{array}$ \\
\hline $\begin{array}{l}\text { CLOSE READING } \\
\text { PROCEDURE }\end{array}$ & $\begin{array}{l}\text { 1. lights are unplugged } 2 \text {. me- } \\
\text { ter selector switch is plugged } \\
\text { in } 3 . \text { meter is switched to last } \\
\text { coil that reads high } 4 \text {. rheo- } \\
\text { stat is adjusted to make me- } \\
\text { ter read } 2.5 \text { rolts } 5 . \text { meter } \\
\text { is switched to next coil (coil } \\
\text { that reads in middle range) } \\
6 . \text { meter is read } 7 . \text { graph is } \\
\text { read }\end{array}$ & $\begin{array}{l}\text { 1. coil indicated } \\
\text { by light is selec- } \\
\text { ted } 2 \text {. number in- } \\
\text { dicated on selec- } \\
\text { tor switch dial is } \\
\text { added to meter } \\
\text { reading }\end{array}$ & $\begin{array}{l}\text { 1. position is } \\
\text { read directly on } \\
\text { meter scale }\end{array}$ & $\begin{array}{l}\text { 1. coil is selected } \\
\text { 2. voltage is ad- } \\
\text { justed 3. meter } \\
\text { is read 4. graph } \\
\text { is read }\end{array}$ & $\begin{array}{l}\text { 1. coil is se- } \\
\text { lected } 2 . \text { num- } \\
\text { bers indicated } \\
\text { on seclector } \\
\text { switch dials are } \\
\text { read as first } \\
\text { two digits and } \\
\text { meter is read } \\
\text { as the third } \\
\text { digit }\end{array}$ & $\begin{array}{l}\text { 1. numbers are } \\
\text { read }\end{array}$ \\
\hline $\begin{array}{l}\text { REGULATION FOR } \\
\text { CLOSE INDICA TION }\end{array}$ & rheostat & $\begin{array}{l}\text { volimeter, rhe- } \\
\text { ostat, coil with } \\
\text { fixed iron core }\end{array}$ & $\begin{array}{l}\text { automatic con- } \\
\text { stant voltage } \\
\text { power supply }\end{array}$ & $\begin{array}{l}\text { voltmeter, vari- } \\
\text { able transformer }\end{array}$ & $\begin{array}{l}\text { automatic con- } \\
\text { stant current } \\
\text { power supply }\end{array}$ & $\begin{array}{l}\text { automatic con- } \\
\text { stant current } \\
\text { power supply }\end{array}$ \\
\hline ADVANIAGES & simple, reliable & $\begin{array}{l}\text { good compromise } \\
\text { between simple } \\
\text { construction and } \\
\text { easy to read close } \\
\text { indication }\end{array}$ & $\begin{array}{l}\text { easy to read } \\
\text { close indication }\end{array}$ & $\begin{array}{l}\text { looks like standard } \\
\text { position indicators, } \\
\text { reliable }\end{array}$ & $\begin{array}{l}\text { easy to read } \\
\text { close indication, } \\
\text { reliable, mag- } \\
\text { nifies move- } \\
\text { ment, accurate }\end{array}$ & $\begin{array}{l}\text { digital indica- } \\
\text { tion, accurate }\end{array}$ \\
\hline DISADVANTAGES & $\begin{array}{l}\text { close reading requires } \\
\text { seven operations }\end{array}$ & $\begin{array}{l}\text { meter is inaccu- } \\
\text { rate if any light } \\
\text { bulb burns out }\end{array}$ & $\begin{array}{l}\text { depends on sen- } \\
\text { sitive relays }\end{array}$ & $\begin{array}{l}\text { close reading rem } \\
\text { quires four opera- } \\
\text { tions }\end{array}$ & $\begin{array}{l}\text { requires a wire } \\
\text { for each inch of } \\
\text { indication from } \\
\text { drive to control } \\
\text { panel }\end{array}$ & $\begin{array}{l}\text { complicated } \\
\text { construction }\end{array}$ \\
\hline REFERENCES & pages 114 thru 117 & $\begin{array}{l}\text { ANL-5768, } \\
\text { pages } 20 \text { thru } 24\end{array}$ & $\begin{array}{l}\text { pages } 118 \text { thru } \\
121\end{array}$ & appendix $B$ & $\begin{array}{l}\text { pages } 122 \text { thru } \\
125\end{array}$ & \\
\hline
\end{tabular}




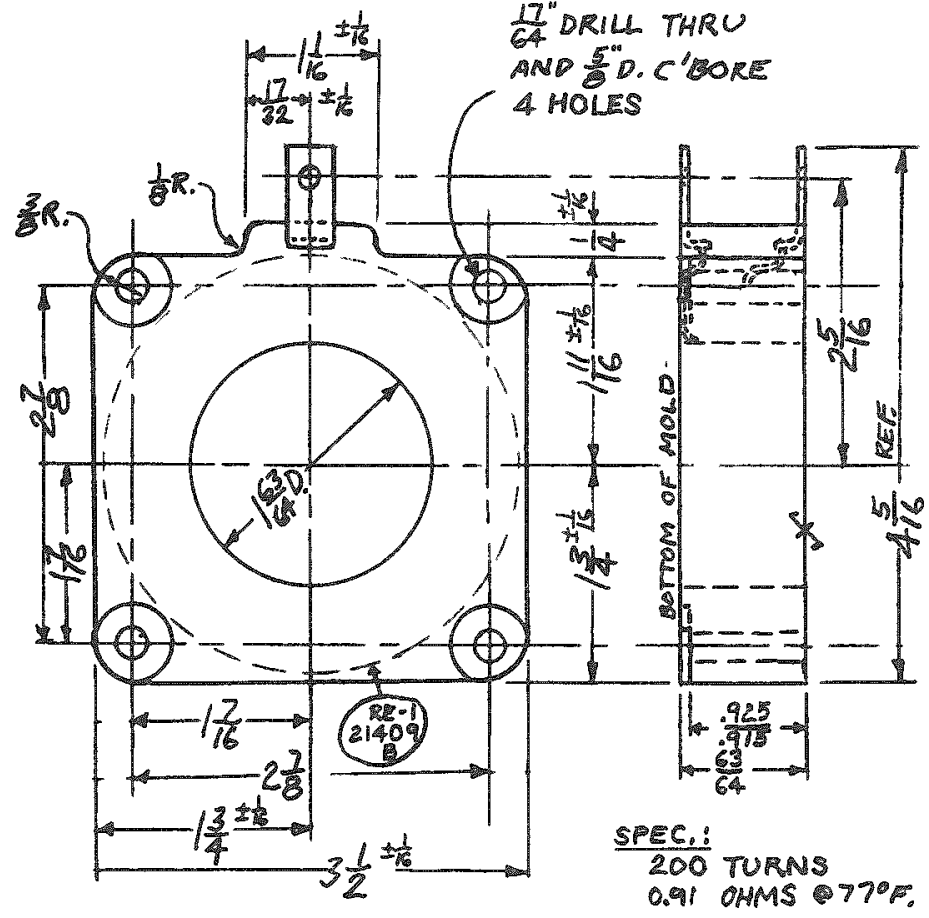

TOL. $: \pm \frac{1}{6 T^{\circ}}$

\section{MOLDED POSITION IHDICATOR COLL CONSTRUCTION HOTES}

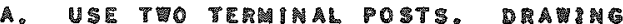

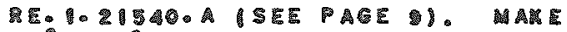
- 1 \% 留 TH SMAL MOLE.

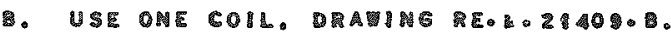
CUT OUTET LEAD TO $1 / 2$ LON AND I

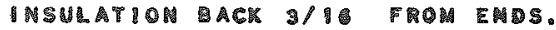

C. SHEVR SOLDET THE LEAD VIES TO THE

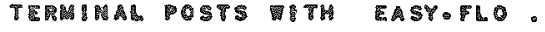

D. HACE THE COIL IN THE MOLD ITM THE

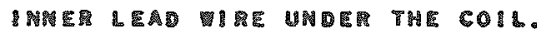

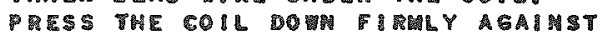
THE BOTTON OF THE WOL

E. VACUUA

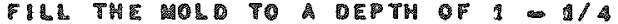

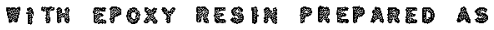

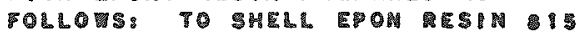

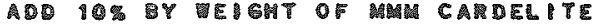

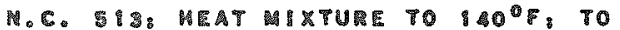

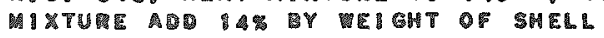
5 METEO STIR VEL USE I A KRE THE FILE

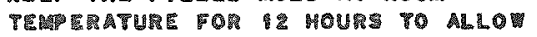

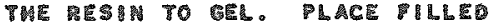

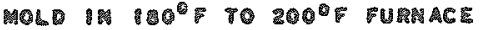

MOLDEO POSITHON MOHGATOR COI

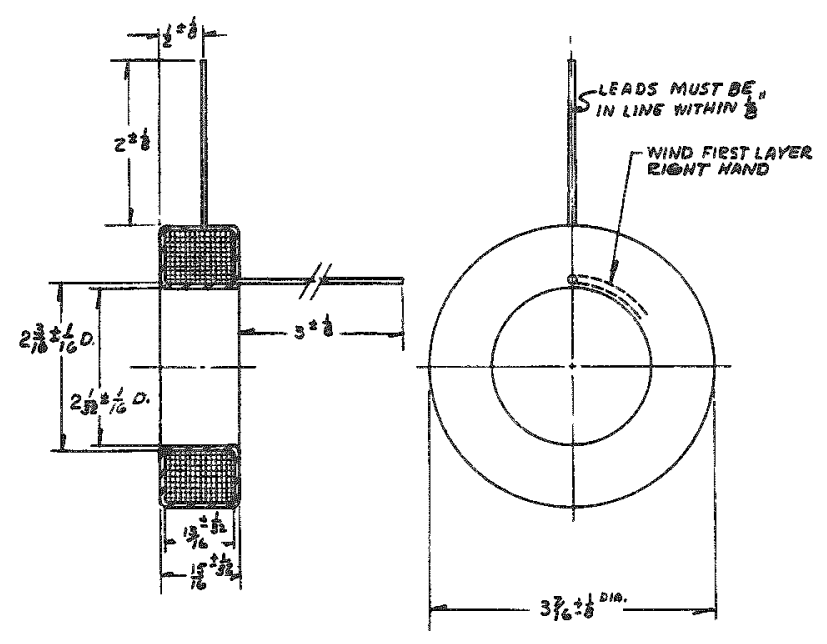

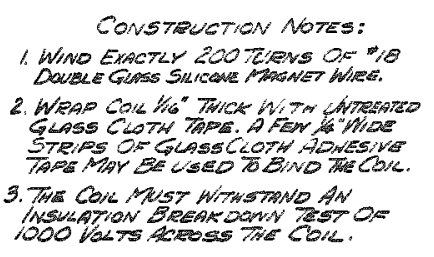

CONSTRUITTON NOTES: WINO EXACTLY 200 TCRES OF

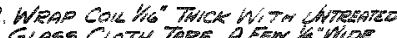
STRIPS OF GLASS COTH HOWESH 3. TH COSL NUST WITHSTHO AN ANSWATIN BREA DEN DSTO 
Light Bulb Type

This type of position indicator is extremely simple and reliable. It is best suited to power reactors where the approximate position of the control rods should be easily seen and where precise measurements of position are needed only occasionally.

The diagram of a position indicator of this type for a 31 -in. travel is shown on page 115. A three-inch coil spacing is close enough, since closer spacing gives an overlapping effect which cancels any benefit derived from having more lights. Using more than one $1-i n$. coil for each 3-in. space would give a greater change in voltage across the light; however, one coil gives sufficient contrast and is more economical.

The voltage across the coil varies from 0.92 to $2.23 \mathrm{v}$ with the light bulbs in the circuit and varies, as shown on page 116, with the light bulbs removed.

The procedure for obtaining close indication, shown below, eliminates the error due to changes in input voltage and almost eliminates the error due to changes in temperature. The position may be read to within one tenth of an inch. The effect of a $150^{\circ} \mathrm{F}$ change in temperature is less than this one tenth of an inch.

The series of coils are held together by $\frac{1}{w}-$ in. threaded rods and nuts on both sides of each coil.

\section{TO OBTAIN CLOSE POSITION INDICATION}

1. Unplug the lights and plug in the meter circuit.

2. Turn the selector switch to the highest number which gives a high meter reading.

3. Adjust the rheostats to make the meter read full scale.

4. Turn the selector switch to the next higher number.

5. Convert the meter reading to inches on the curve numbered as indicated by the selector $\mathrm{s}$ witch. 


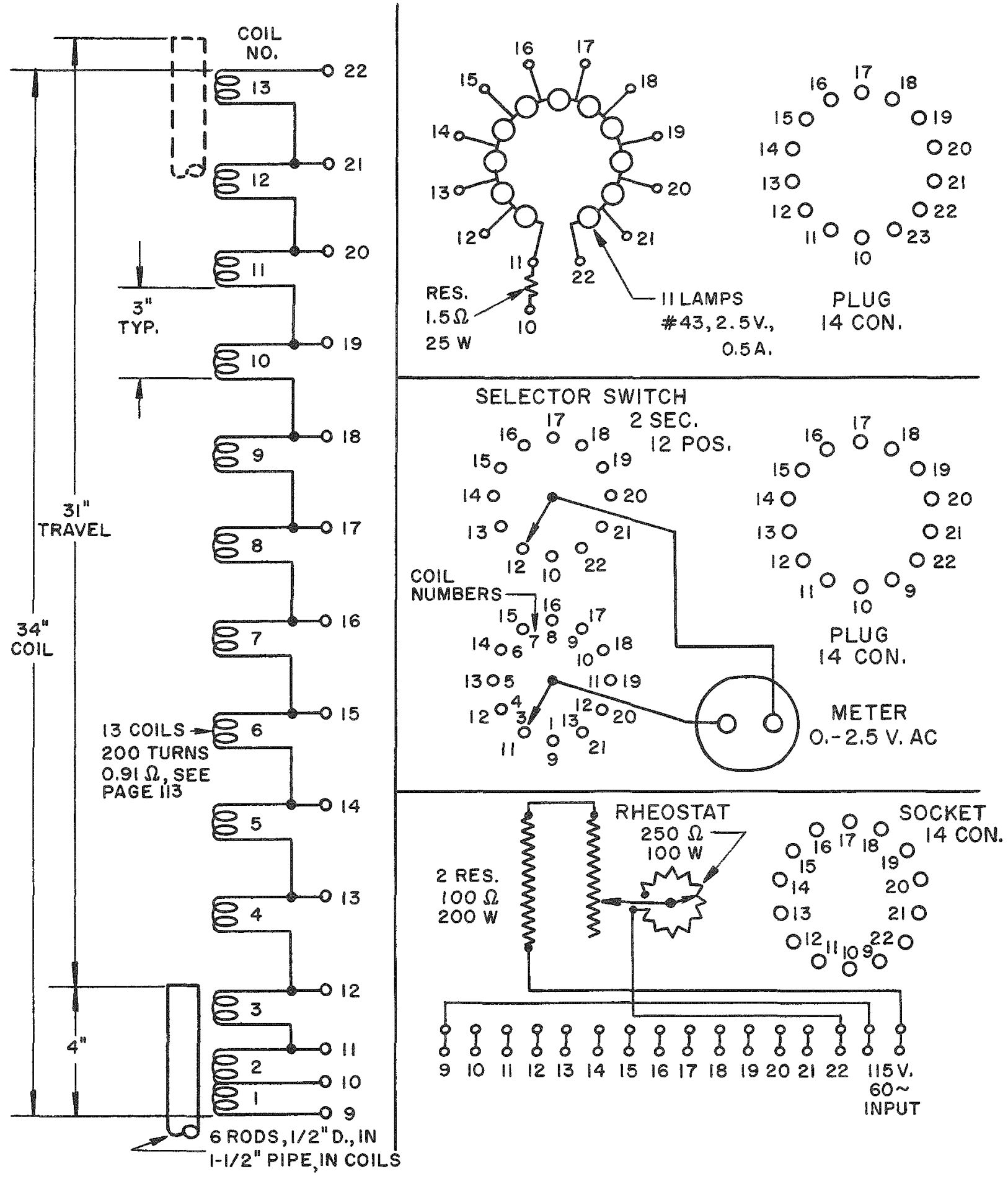

LIGHT BULB-TYPE POSITION INDICATOR (SCHEMATIC) 
VOLTAGE VARIATION ACROSS COIL

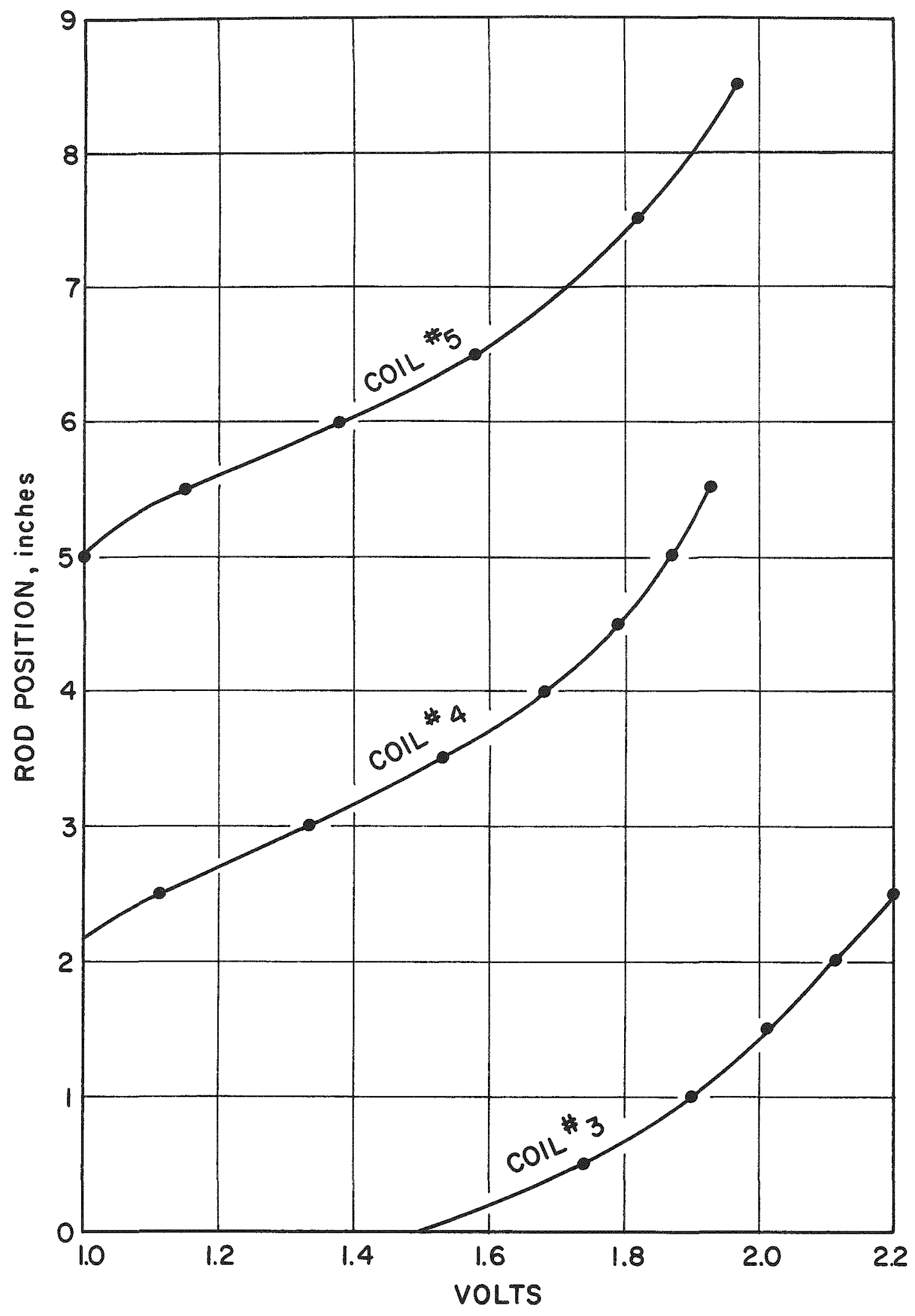




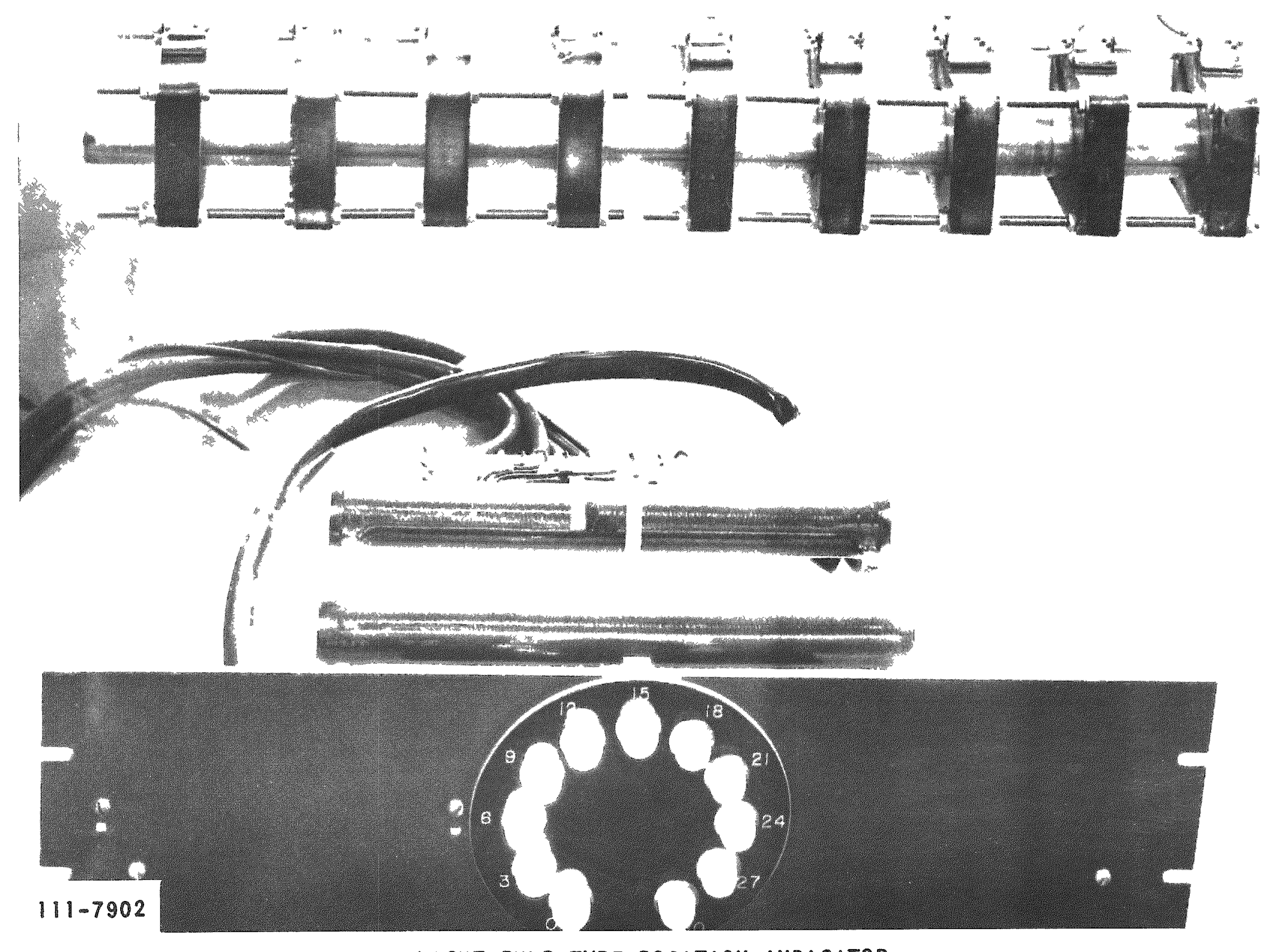

LIGHT BULB TYPE POSITION INDICATOR 


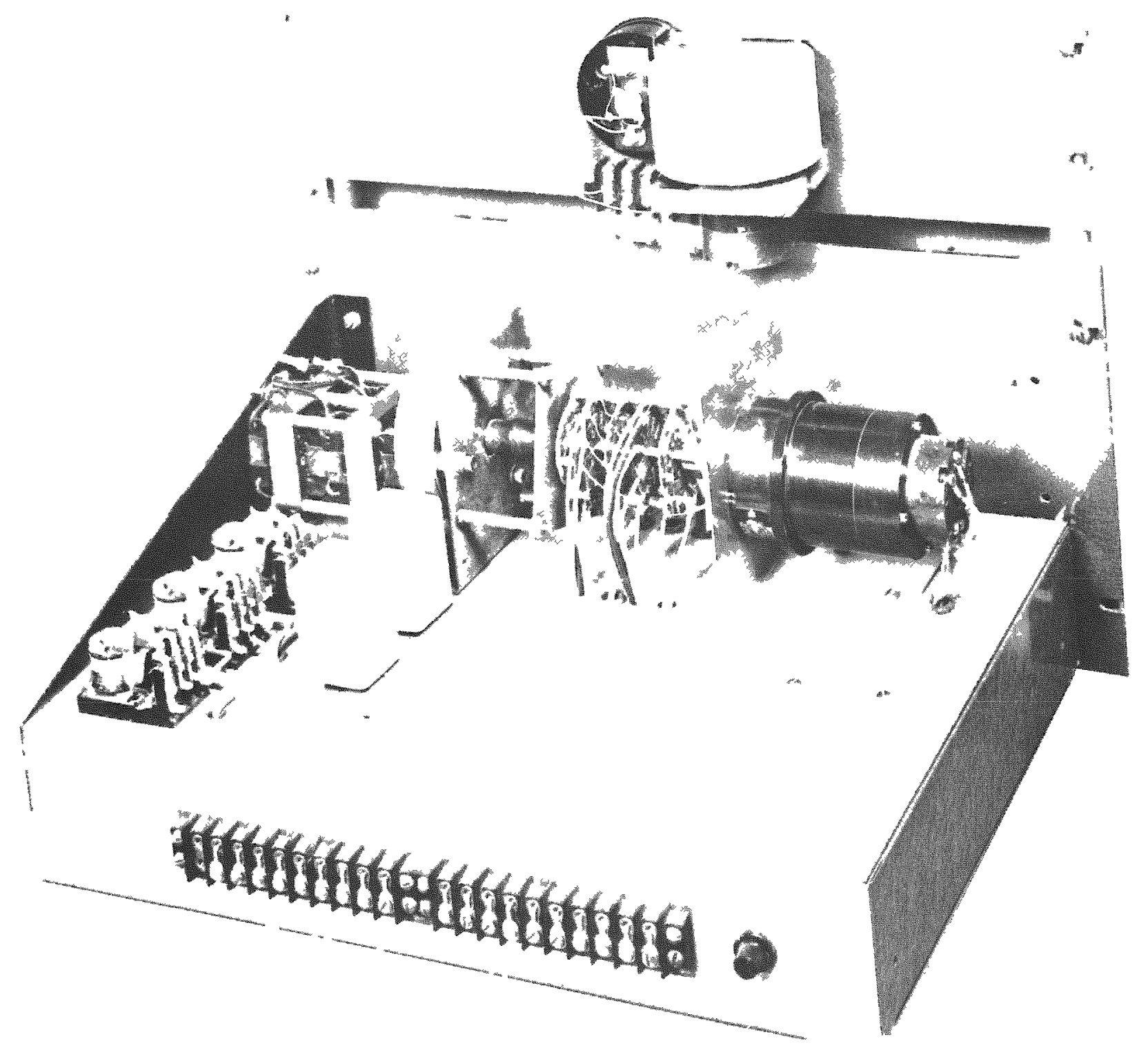

$111-7906$

AUTOMATIC METER TYPE POSITION INDICATOR

(BACK VIEW) 


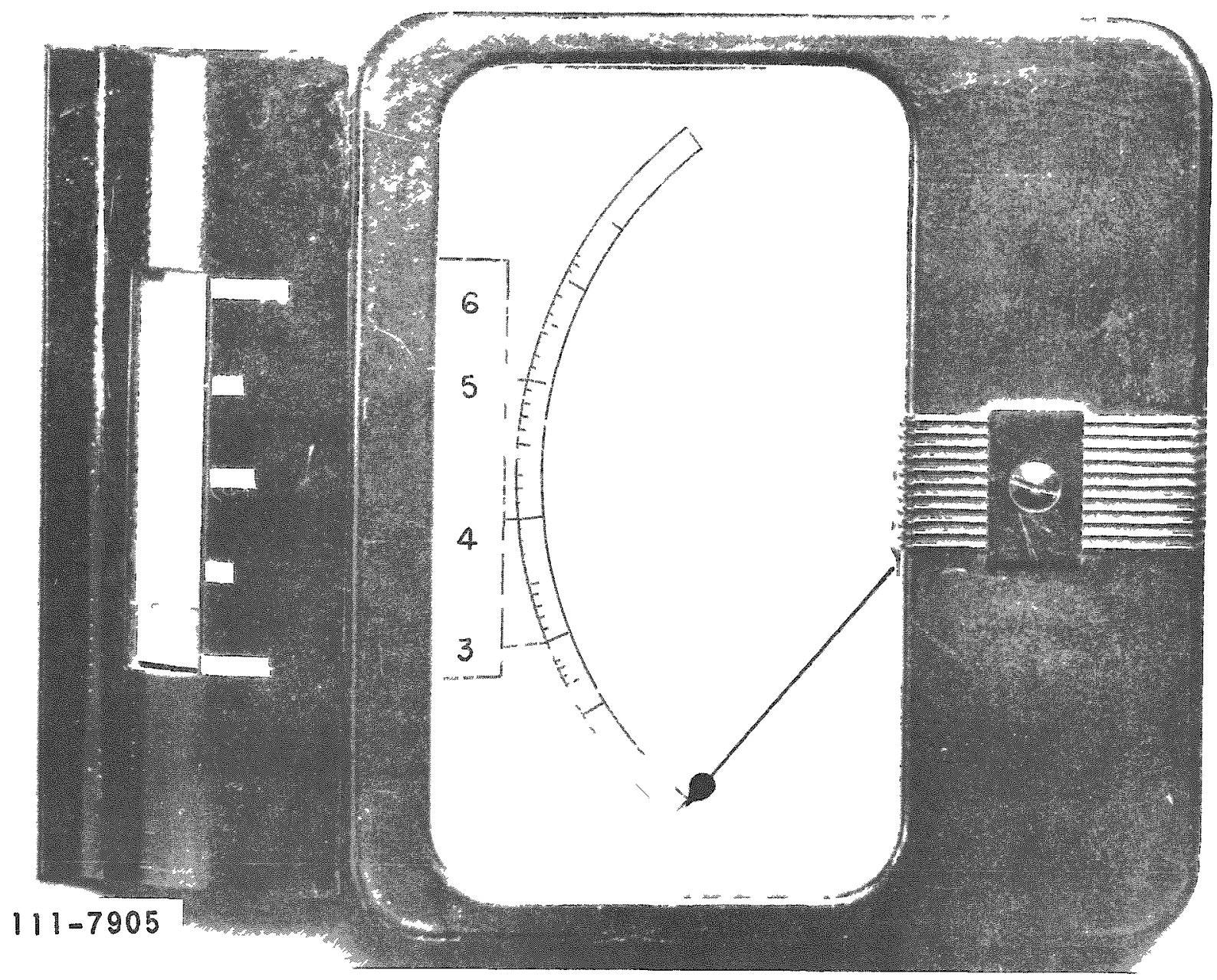

AUTOMATIC METER TYPE POSITION INDICATOR PANEL 


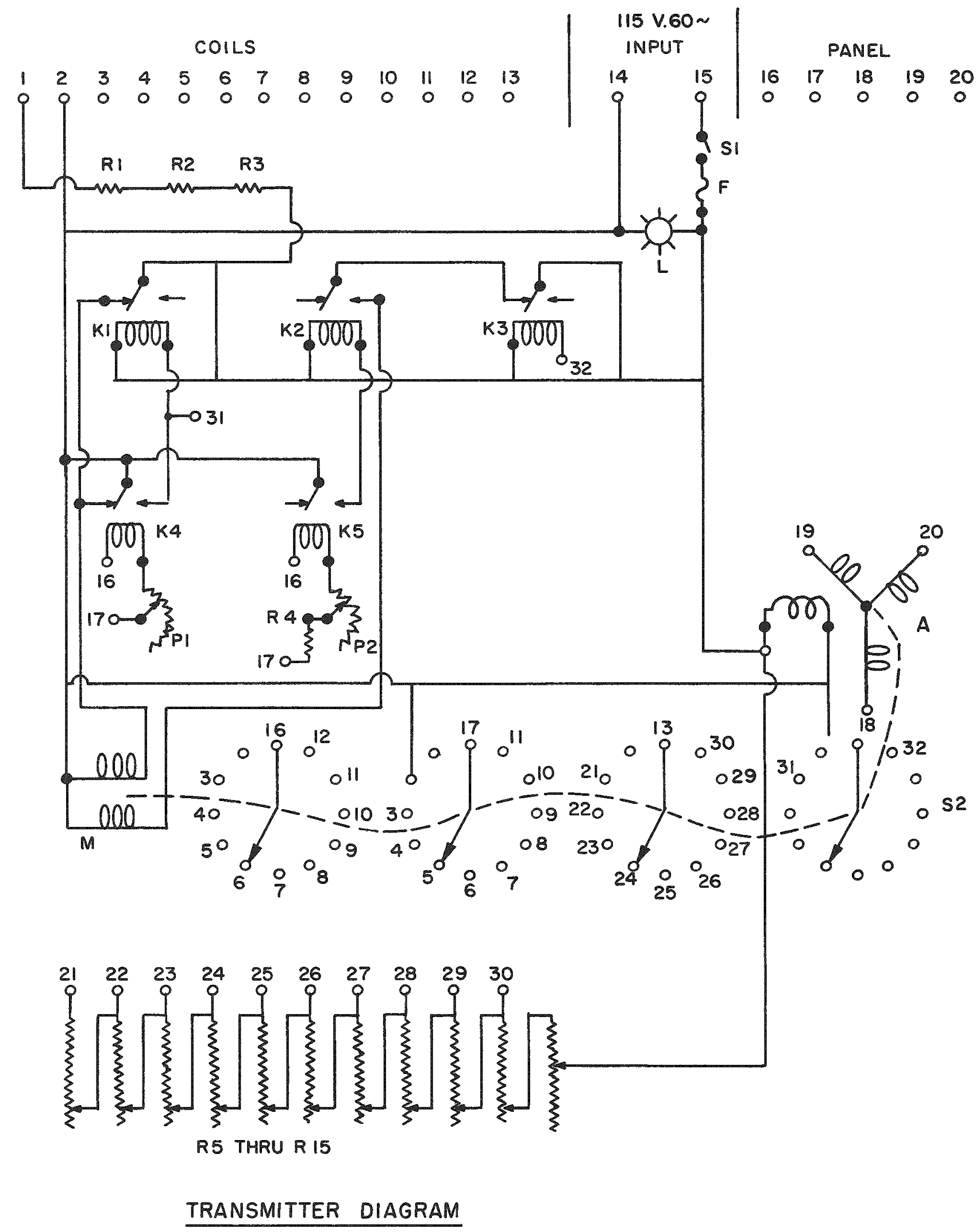
AUTOMATIC METER POSITION INDICATOR 


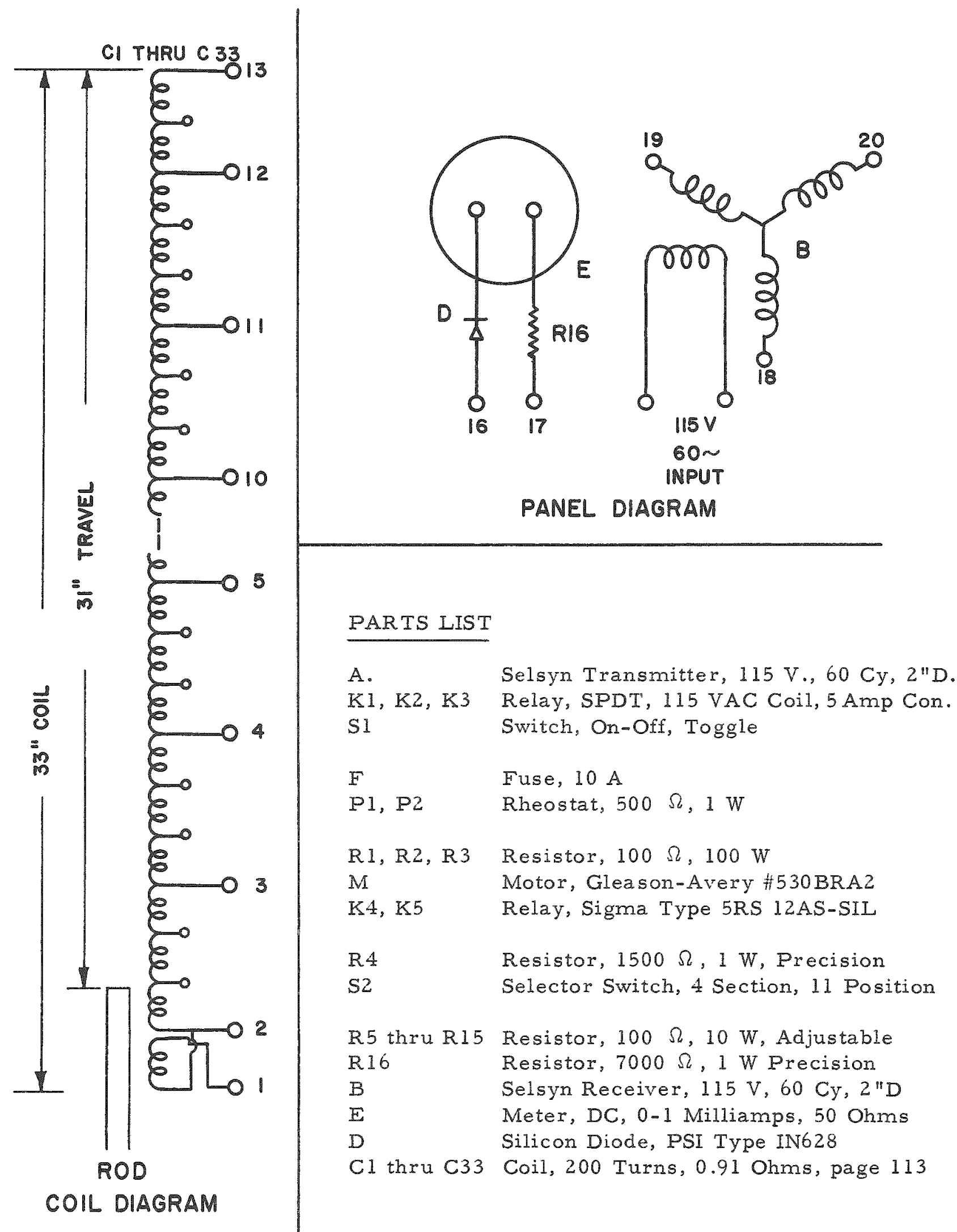


Test Results of the Decade Switch-type Position Indicator

A test was made to determine the effect of changes in temperature. The part of the system which is located at the drive consists of the drive rod, the pipe and the set of coils. Any one of these will increase the meter reading if temperature increases. This would give a lower position reading, since the inch scale is reversed. The following table gives the effect of temperature on the 0 to 48 -in. meter at various rod positions:

\begin{tabular}{|l|rrrrrrrrr|}
\hline rod position & \multicolumn{1}{|c|}{0} & 6 & 12 & 18 & 24 & 30 & 36 & 42 & 48 \\
\hline inches per ${ }^{\circ} \mathrm{F}$ & 0.067 & 0.053 & 0.042 & 0.034 & 0.027 & 0.020 & 0.013 & 0.0078 & 0.0045 \\
\% due to rod & 44 & 44 & 43 & 43 & 42 & 39 & 35 & 30 & 24 \\
\% due to pipe & 51 & 50 & 50 & 50 & 50 & 50 & 48 & 42 & 28 \\
\% due to coil & 5 & 6 & 7 & 7 & 8 & 11 & 17 & 28 & 48 \\
\hline
\end{tabular}

The effect of temperature on the 0 to 1 -in. meter is $0.0023 \mathrm{in}$. per ${ }^{\circ} \mathrm{F}$ at the 1 -in. end of the scale, and is $0.0033 \mathrm{in}$. per ${ }^{\circ} \mathrm{F}$ at the 0 -in. end. 


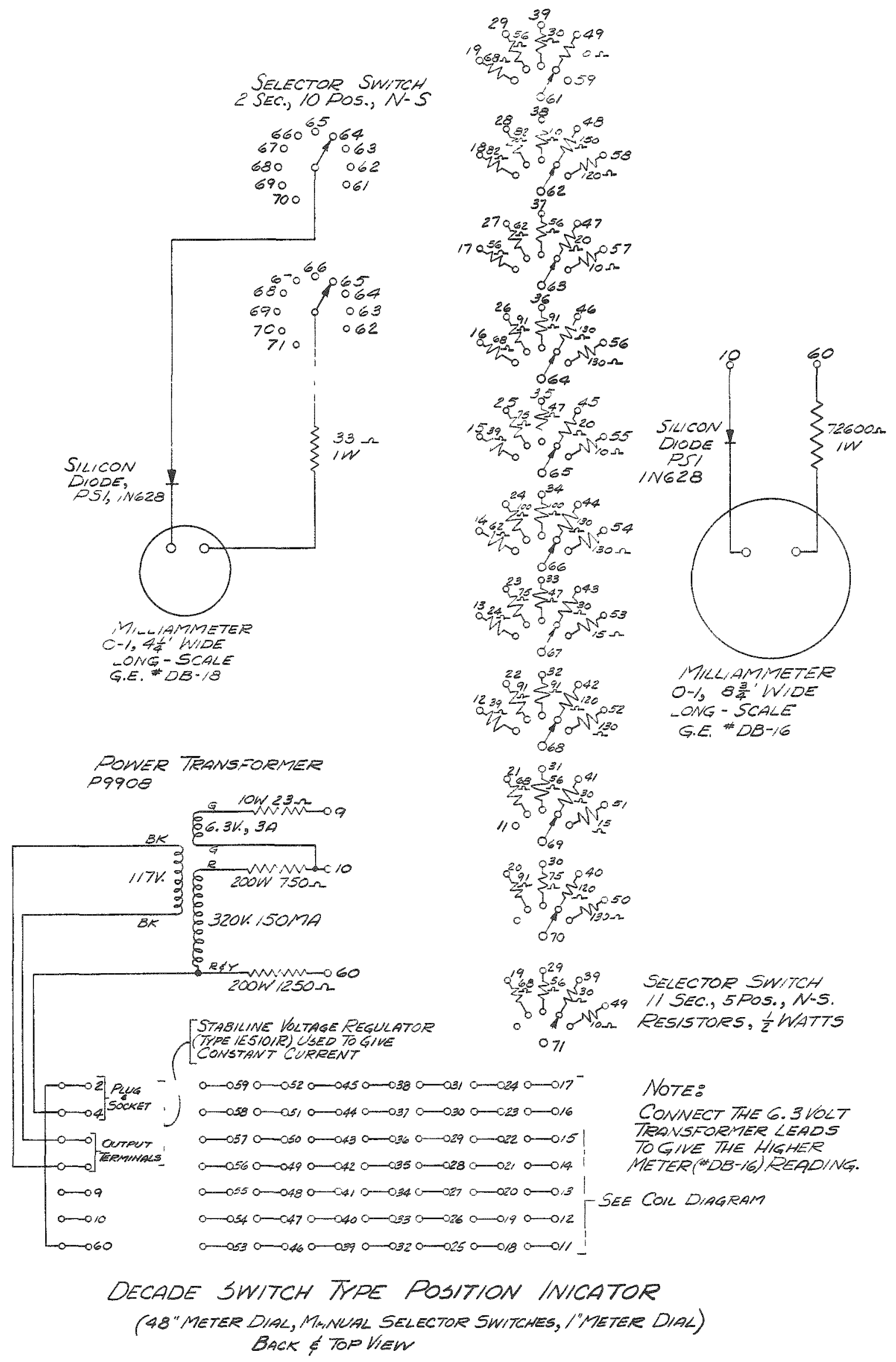

RE-2-30138-C 


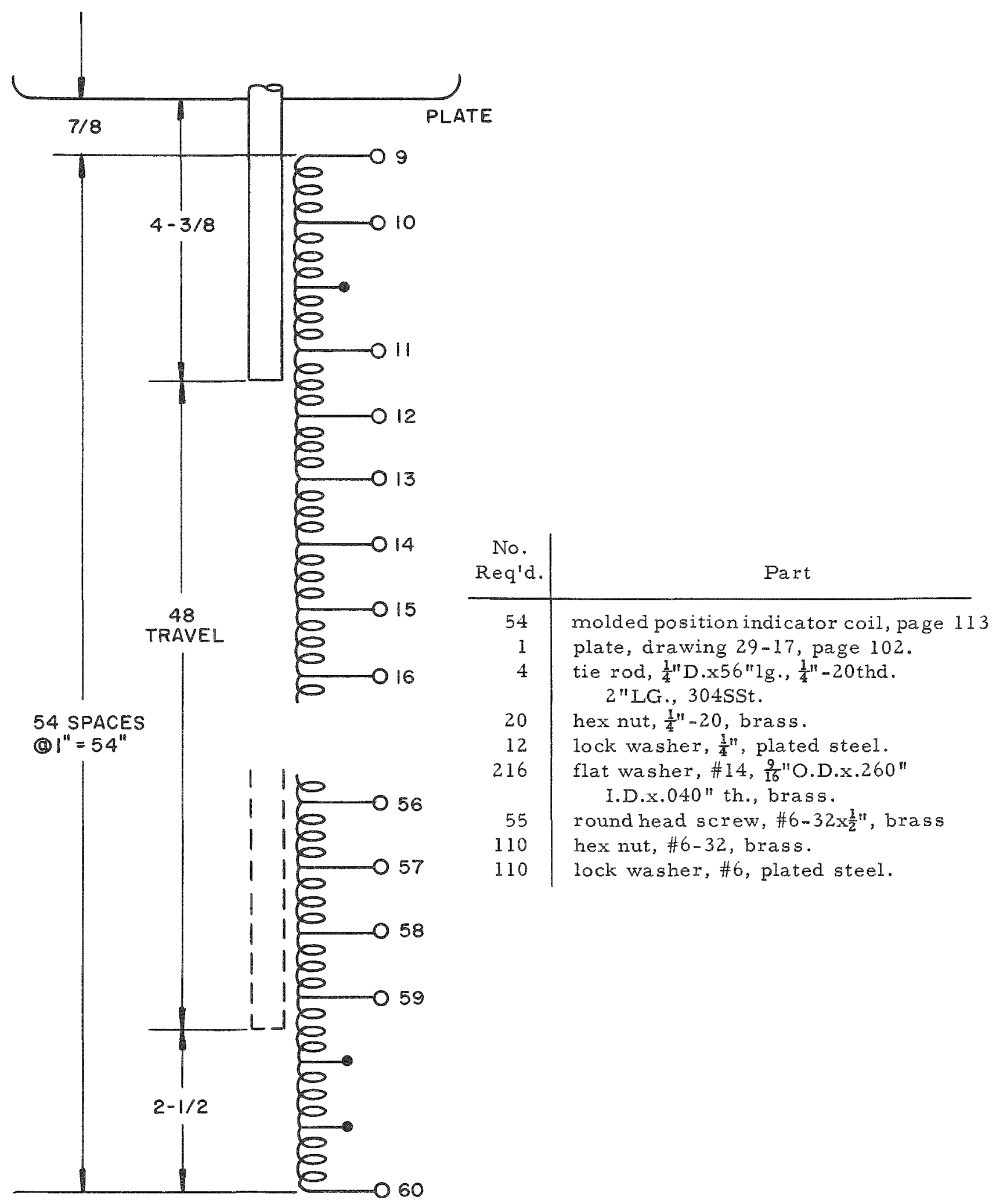



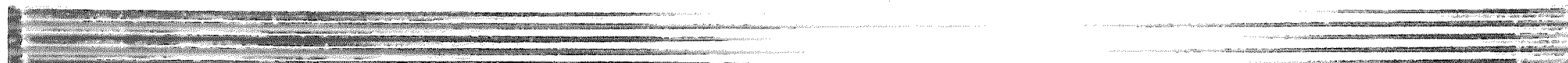

10

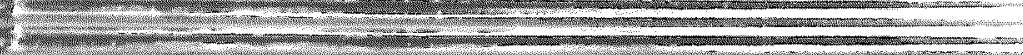

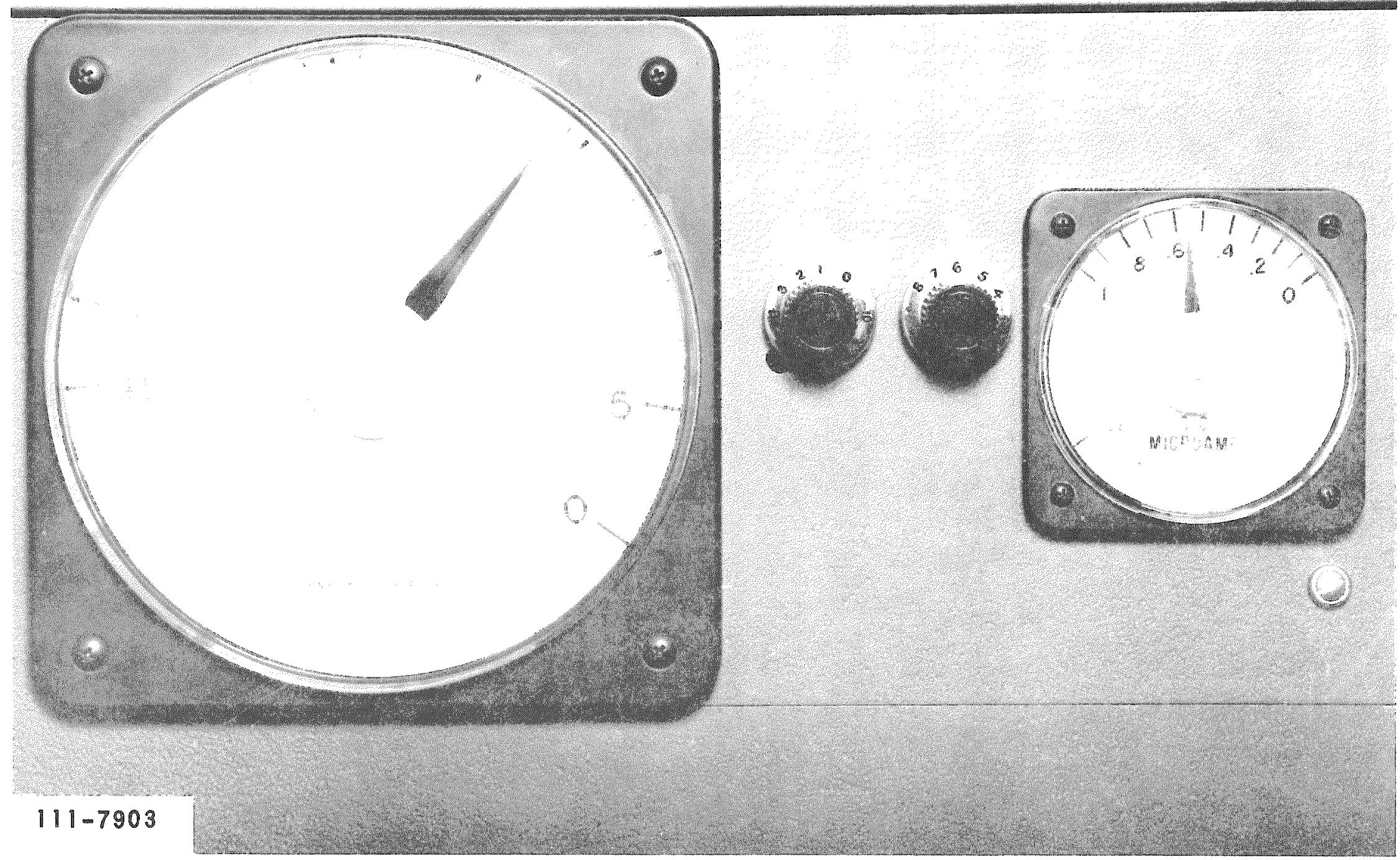

DECADE SWITCH TYPE POSITION INDICATOR PANEL 
-

- 


\section{APPENDIX E}

\section{DESTRUCTION TEST OF A MODEL OF THE PRESSURE SHELL}

Introduction

Driving the control rods of a nuclear reactor requires that controlled power be transmitted to the inside of the reactor pressure vessel, preferably while maintaining an hermetically sealed system. The transmission of magnetism through the wall of a pressure vessel is one way of doing this. This is the basis of the magnetic jack control rod drive, the pressure shell of which 1 s the subject of this report. On page 12 are 2 drawing and specifications of this high-pressure magnetic jack. The test vessel is a short, but otherwase identical, model of the actual vessel. The drawings of these are on page 145.

This pressure vessel is unlque in that it requires magnetic ring sections separated by narrow nonmagnetic sections and also one long nonmagnetic section. Moderate corrosion and heat resistance is another requirement For the $3 \frac{1}{2}$ in. ID tube a wall thickness equal to about one eighth of the inside diameter is desirable from the standpoint of magnet design. This is also a good compromse between having low stresses and a coil of small diameter. A coil of small diameter is desirable for its low electrical resistance and for keeping down the size of the magnetic jack. The $\frac{9}{\frac{9}{6}}$ in. ID tube is made extra heary so that it will not break under pressure if the end of the long pipe happens to be bumped. The long nonmagnetic section is made of $1 \frac{1}{2}$ in. schedule 40 pipe for economical reasons. In special cases the bore could be $1 \frac{9}{16}$ in. in diameter to reduce the stresses.

The pressure shell is made in two pieces which are assembled after final machining. The small-diameter piece (extension) is inserted through the larger piece (body) so that the pressure load is taken on the back of extension flange and the inside of the body head. A small fillet weld seals the joint. Making the vessel in two parts is done to facilitate boring the small tube and also to help allow for axial shrinkage due to welding. Each large weld shrinks about $\frac{1}{16}$ in. axially and the small welds shrink about $\frac{3}{64}$ in.

The parts to be welded together are provided with a back-up ring integral with one of the mating parts and a small area for butting the parts together. This preparation gives a joint which is straight and concentric. The other welds, the only purpose of which is to provide the nonmagnetic sections, are made in grooves cut in the rough-machined tubes. 
Inco-weld "A" was selected for the weld metal. Stainless steel, AISI type 430, was selected for the base metal (magnetic sections). Inconel was selected for the long nonmagnetic section. These materials have about the same thermal expansion.

The vessel is welded with a relatively new weld rod material in a geometry which cannot be calculated readily; however, the gasket and flange designs incorporate other experiences at ANL. 3 Therefore this test was performed to check the material and design as required by the ASME Boiler and Pressure vessel Code Par. UG101 of section VIII.

Test Apparatus

The test was made at the Steel City Testing and Engineering Laboratories, since Argonne does not have facilities for the high pressures involved. The large end of the vessel was closed off with a blind flange (see page 146). The other end of the vessel was connected to a high-pressure hose. For the first test the hose was connected to a hand pump. For the other two tests an air-driven, reciprocating water pump was used.

Test Data.

The test vessel was the same for all three tests except that after the second test the flange end of the tube was cut off and a new thicker flange was welded on the tube.

The test data are described on pages 130 through 135 , which are reprints of the test reports from the Steel City Test Lab.

\section{Test Results}

\begin{tabular}{|c|c|c|c|}
\hline Test Number & 1 & 2 & 3 \\
\hline Pressure, psi. & 11,300 & 12,650 & 12,800 \\
\hline Result & $\begin{array}{l}1 \frac{1}{2}-i n \text { pipe section } \\
\text { began to yield }\end{array}$ & $\begin{array}{l}\text { flanged end of } \\
\text { large tube sec- } \\
\text { tion (as origi- } \\
\text { nally designed) } \\
\text { failed }\end{array}$ & $\begin{array}{l}\text { large tube section } \\
\text { failed (flange } \\
\text { cracked due to } \\
\text { failure of tube } \\
\text { section }\end{array}$ \\
\hline Page no. of photo & 126 & 126 thru 131 & 132,133 \\
\hline $\begin{array}{l}\text { Diameters: } \\
\text { large tube before } \\
\text { large tube after }\end{array}$ & 4.39 & 4.41 & $\begin{array}{l}4.41 \\
\text { ruptured }\end{array}$ \\
\hline $\begin{array}{l}\text { middle tube before } \\
\text { middle tube after }\end{array}$ & $\begin{array}{l}2.21 \\
2.21\end{array}$ & $\begin{array}{l}2.21 \\
2.21\end{array}$ & $\begin{array}{l}2.21 \\
2.21 *\end{array}$ \\
\hline $\begin{array}{l}1 \frac{3}{2}-\text { in. pipe before } \\
1 \frac{1}{2}-\text { in. pipe after }\end{array}$ & $\begin{array}{l}1.90 \\
2.06\end{array}$ & $\begin{array}{l}2.06 \\
2.10\end{array}$ & $\begin{array}{l}2.10 \\
2.12\end{array}$ \\
\hline
\end{tabular}

*2.22 near joint with pipe

${ }^{3}$ N. Balai, T. L. Kettles, and R. E. Bailey, Reactor Pressure Vessel Design for Nuclear Applications, Symposium on Radiation Effects on Materials, Vol.3, Special Technical Publication, No. 233, ASTM (1958) 
The test shows that the large tube section is the weakest part of the vessel. This is good, since the tube thickness is the part which is least convenient to make heavier. The middle tube showed no yielding. The pipe came with a smooth finish and an extra thick wall (0.150 in.). Perhaps a pipe of standard quality would have failed.

Apparently the 430 SST steel bar which was used for the large tube was of low quality, since the test showed an ultimate stress of 59,000 psi. The ultimate stress should be about 75,000 psi.

The flexitallic gasket (2500 psi standard) was slightly deformed where the flange split, but showed no sign of failure or leakage. This indicates that the gasket and the bolting are adequate.

None of the welds failed and the appearance of the crack in the vessel indicates that the weld is quite ductile.

\section{Conclusions}

The rest indicates that the vessel has a design pressure of 3200 psi at room temperature. Calculations indicate a code design pressure of 2800 psi at $100 \mathrm{~F}$ (radiographed welds of $90 \%$ efficiency).

Two changes in the design resulted from the test: the flanged end of the ressel was made thicker and the pipe plug hole at the other end was changed from $\frac{1}{2}$ to $\frac{3}{8} \mathrm{in}$.

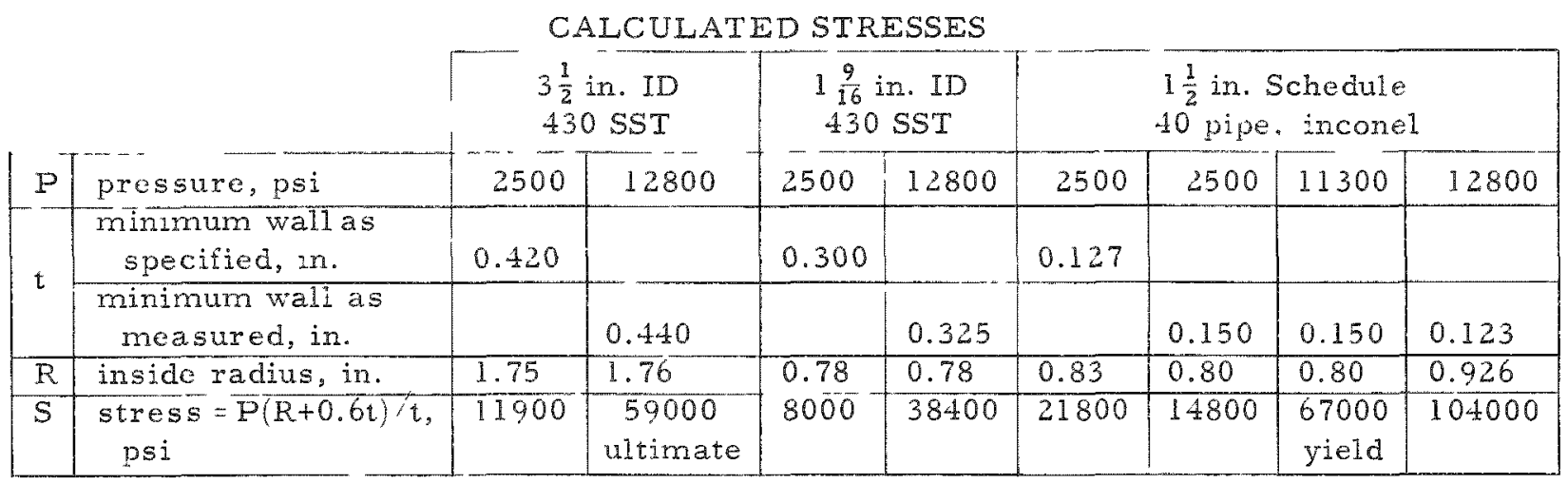

\begin{tabular}{|c|c|c|c|}
\cline { 3 - 4 } \multicolumn{2}{l|}{} & $\begin{array}{c}\text { flange used for tests } \\
\text { no. } 1 \text { and } 2\end{array}$ & $\begin{array}{c}\text { flange used for test no. } 3 \\
\text { (final design) }\end{array}$ \\
\hline$P$ & pressure, psi & 2500 & 2500 \\
\hline & actual flange thickness, in. & $2 \frac{1}{8}$ & $2 \frac{5}{8}$ \\
\hline$t$ & $\begin{array}{c}\text { thickness used in calculating } \\
\text { to allow for centerbore, in. }\end{array}$ & 2 & $2 \frac{1}{2}$ \\
\hline$S_{H}$ & logitudinal hub stress, psi & 9000 & 6750 \\
\hline$S_{R}$ & radial flange stress, psi & 2730 & 1670 \\
\hline$S_{T}$ & tangential flange stress, psi & 9520 & 5990 \\
\hline
\end{tabular}




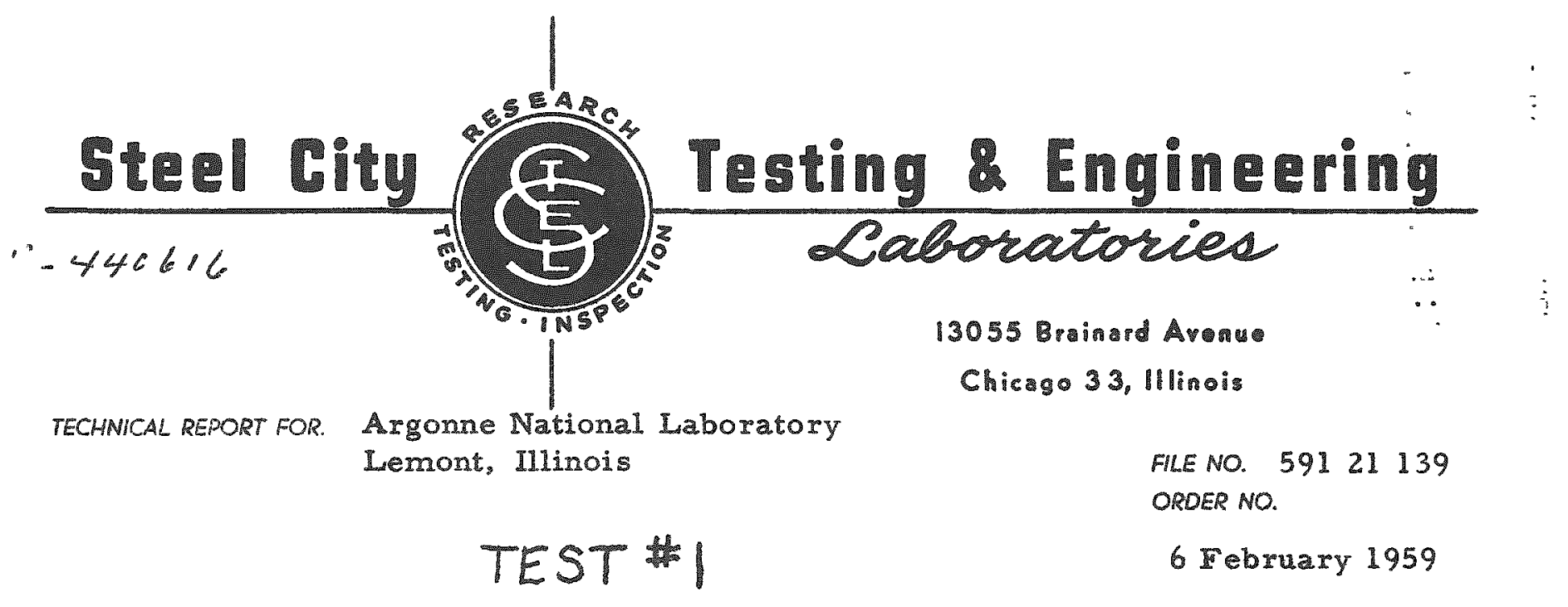

SURUECT: Pipe Assembly

INVESTIGATION Hydraulic pressure test on capped pipe assembly.

\section{FOREWORD:}

A three diameter welded pipe assembly was capped at the large end by the use of a gasket and two bolted flanges. The small end of the assembly was made with a pipe thread and thru this connection the assembly was connected to a hydraulic pump. The assembly was then pressurized until failure occurred.

\section{TEST PROCEDURE:}

The eight $11 / 4-8 \mathrm{~N}$ studs and nuts were thoroughly cleaned and greased. The gasket surfaces were cleaned and the test unit assembled. The nuts were systematically torqued to 550 pound feet. The assembly was then filled with water and connected to a high pressure pumping system. The pressure was slowly increased 


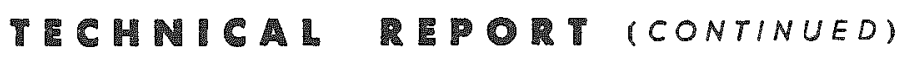

TEST \#

FO R: $\quad$ Argonne National Laboratory

and observed to determine the first point of failure.

\section{RESULTS OF TEST:}

The smallest diameter section of the pipe assembly began to yield and increase in size at 11,300 psig. The pressure was relieved and the extent of damage was examined. Mr. M. T. Burns requested that the pressure be re-applied to the test unit. With the second application of pressure the yield pressure was raised to 12,000 psig and maintained for a short period of time to increase the extent of damage. At this point the test was concluded.

Respectully submitted,

EFI/ac

STEEL CITY TESTING \& ENGINEERING LABORATORIES, INC.

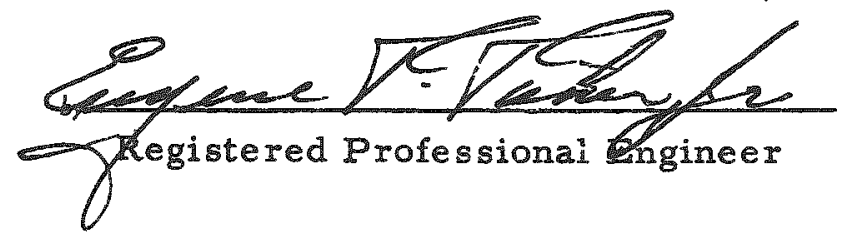




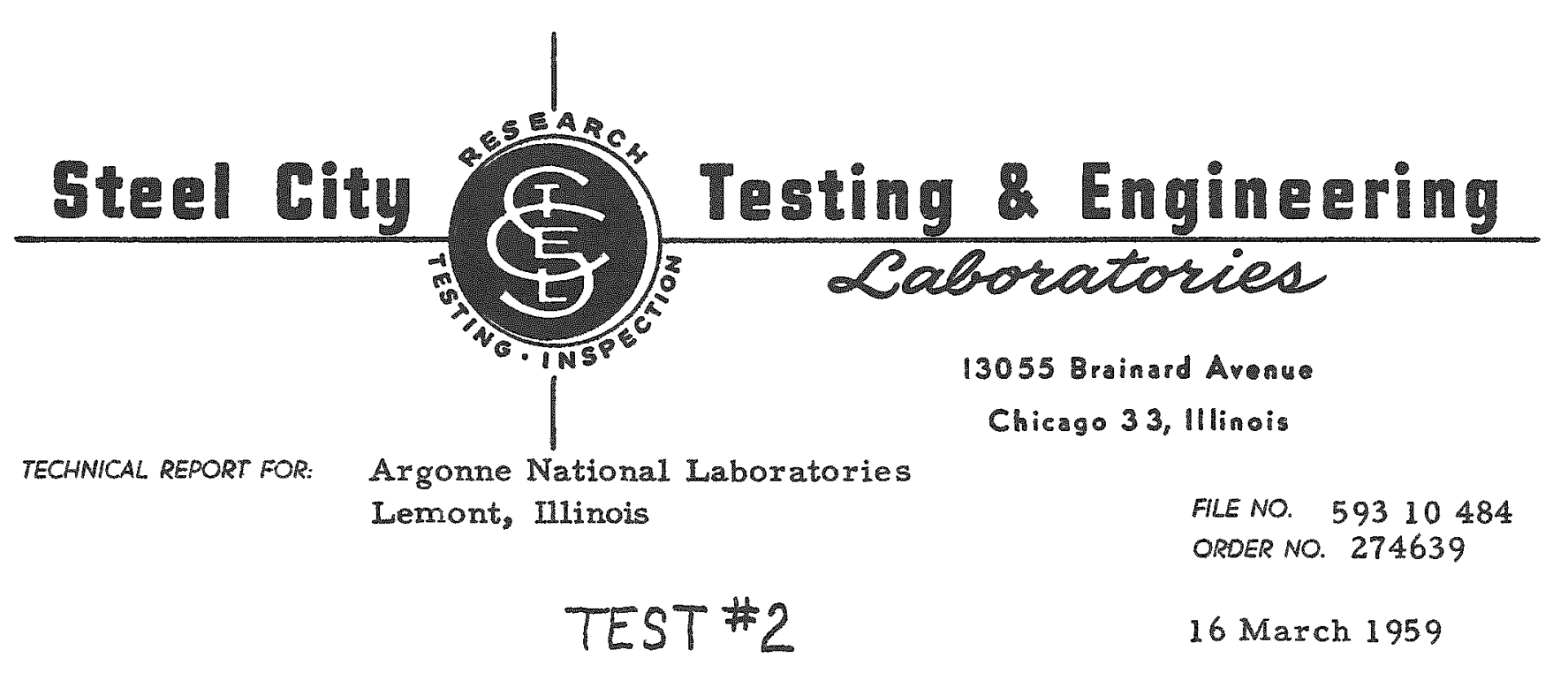

SUBJECT: Pipe Assembly

INVESTIGATION Hydraulic Pressure test on capped pipe assembly.

\section{FOREWORD:}

A three diameter welded pipe as sembly was capped on the large end by the use of a Flexitallic gasket and two bolted flanges. The small end of the assembly was made with a half inch pipe thread and through this connection the assembly was connected to a hydraulic pump. The assembly was then pressurized until failure occurred.

This unit was previously tested on our file number 59121139. At this time the unit was considered to have failed by $M r . M . T$. Burns of Argonne National Laboratory and the test was concluded. This same unit as assembled in this previous test was retested and the hydraulic pressure applied until an actual metal failure occurred. 


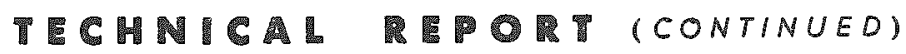

TEST 2

FO R: Argonne National Laboratories

\section{TEST PROCEDURE:}

The assembly was filled with water and then connected to a high pressure pumping system. The pressure was slowly increased until failure occurred.

\section{RESULTS OF TESTS:}

The small diameter section of the pipe assembly continued to yield as pressure was applied. This yielding caused the half inch pipe connection to leak. The pressure was then relieved and the pipe joint tightened. This operation was repeated twice before the conclusion of the test.

At 12, 650 psig, the heavy flanged collar on the largest of the three pipe sections cracked in several places, causing the Flexitallic gasket to blow out with the loss of all pressure and charging

fluid. Figure Nos. 1, 2, 3, 4, 5 and 6 depicts the failed section after disass embly.

Mr. Joseph Young from Argonne National Laboratories, witnessed the test. Mr. Young returned the test unit to Argonne National Laboratories at the completion of the test.

MNP/jw

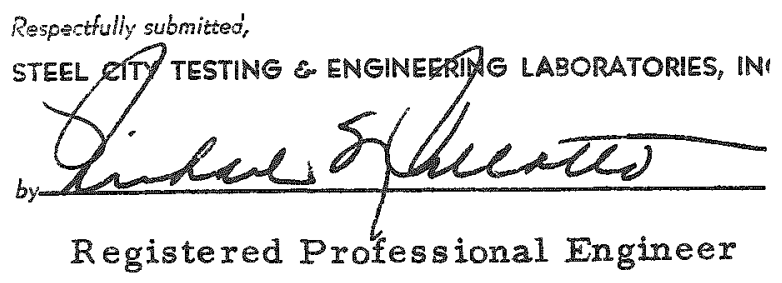




\section{Steel City $\frac{\text { Testing \& Engineering }}{\text { Caboratoried }}$ 13055 [Bainard Avenu \\ Chicago 33 , lllinois \\ TECHNICAL REPORT FOR: Argonne National Laboratories Lemont \\ FILE NO. 59428871 \\ Illinois \\ ORDER NO. 443378 \\ TEST \#3 \\ 29 April 1959}

SUUECT: Pipe Assembly

INVESTIGATION Hydraulic Pressure test on capped pipe assembly.

FOREWORD:

A three diameter welded pipe assembly was capped on the large end by the use of a Flexitallic gasket and two bolted flanges. The small end of the assembly was made with a half inch pipe thread and through this connection the assembly was connected to a hydraulic pump. The assembly was then pressurized until failure occurred. 


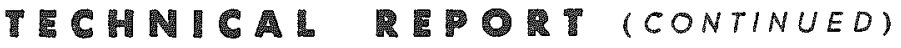 TEST \#3}

F OR: Argonne National Laboratories

\section{TEST PROCEDURE:}

The assembly was filled with water and then connected to a high pressure pumping system. The pressure was slowly increased until failure occurred.

RESULTS OF TESTS:

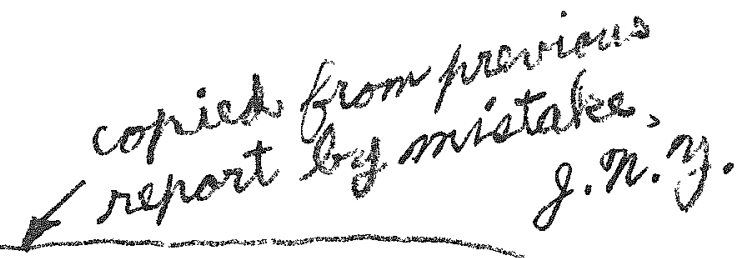

At 12,800 psig, the heavy flanged collar on the largest of the

three pipe sections cracked in several places, causing the Flexitallic gasket to blow out with the loss of all pressure and charging

fluid. Figure No. 1 depicts the failed section before disassembly.

Figure No. 2 and 3 depicts the failed section after disassembly.

Mr. Joseph Young from Argonne National Laboratories,

witnessed the test. The test specimen was packaged and returned

to Argonne National Laboratories, Lemont, Illinois.

$\mathrm{MNP} / \mathrm{jw}$

Respestully submitteg

STEEL CITY TFSTING \& ENGINEERING LABORATORIES, INC.

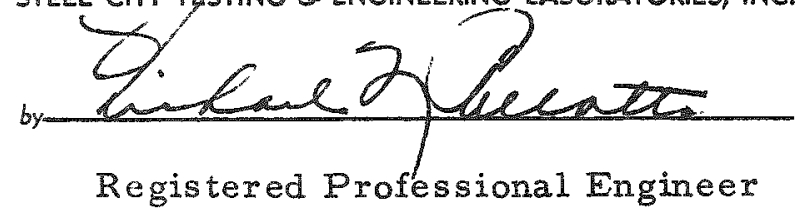


F OR: Argonne National Laboratories

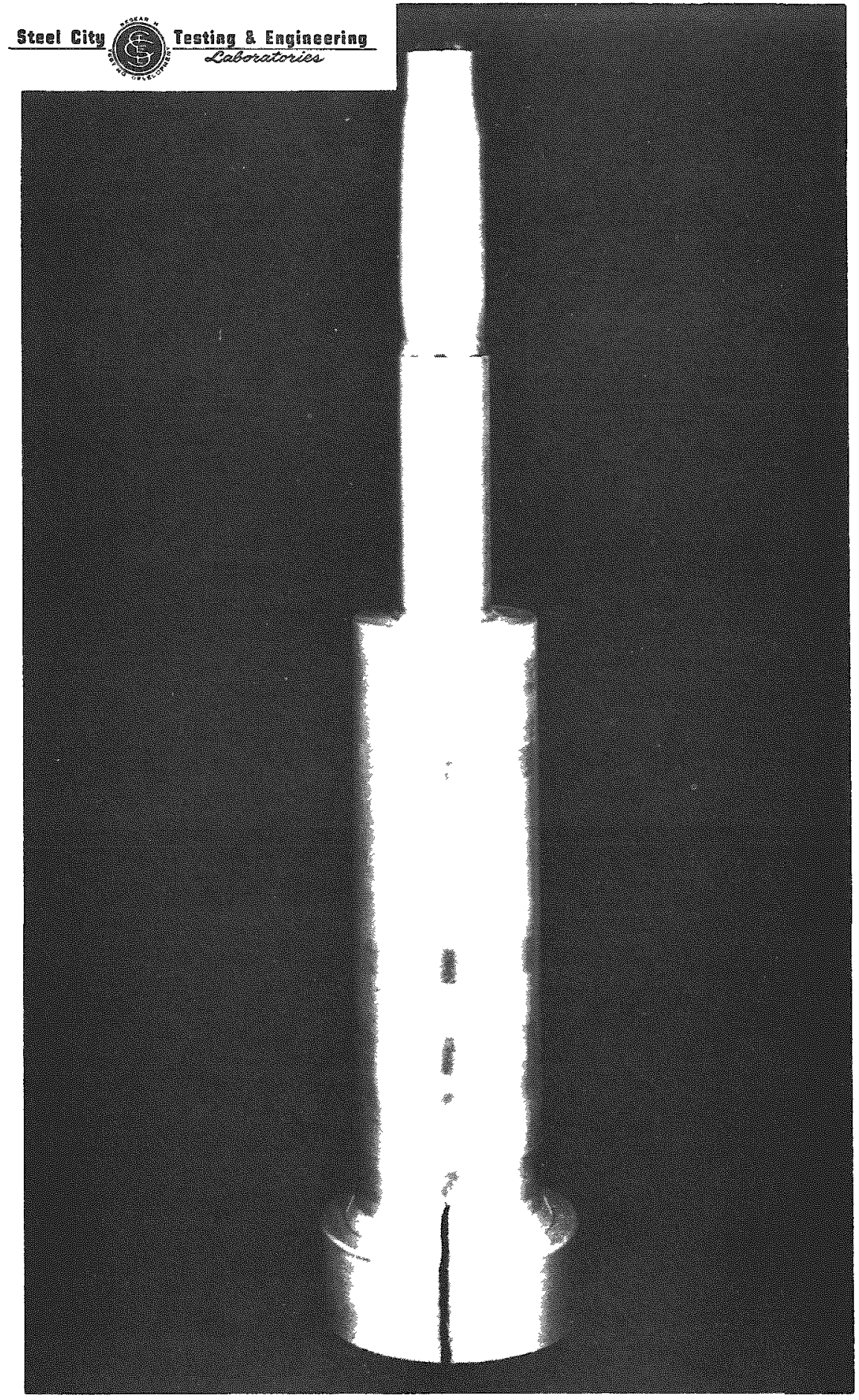

Figure No. 1

Large crack at flanged end. Note deformation of material on smallest diameter pipe section. 
TEST 2

FOR: Argonne National Laboratories

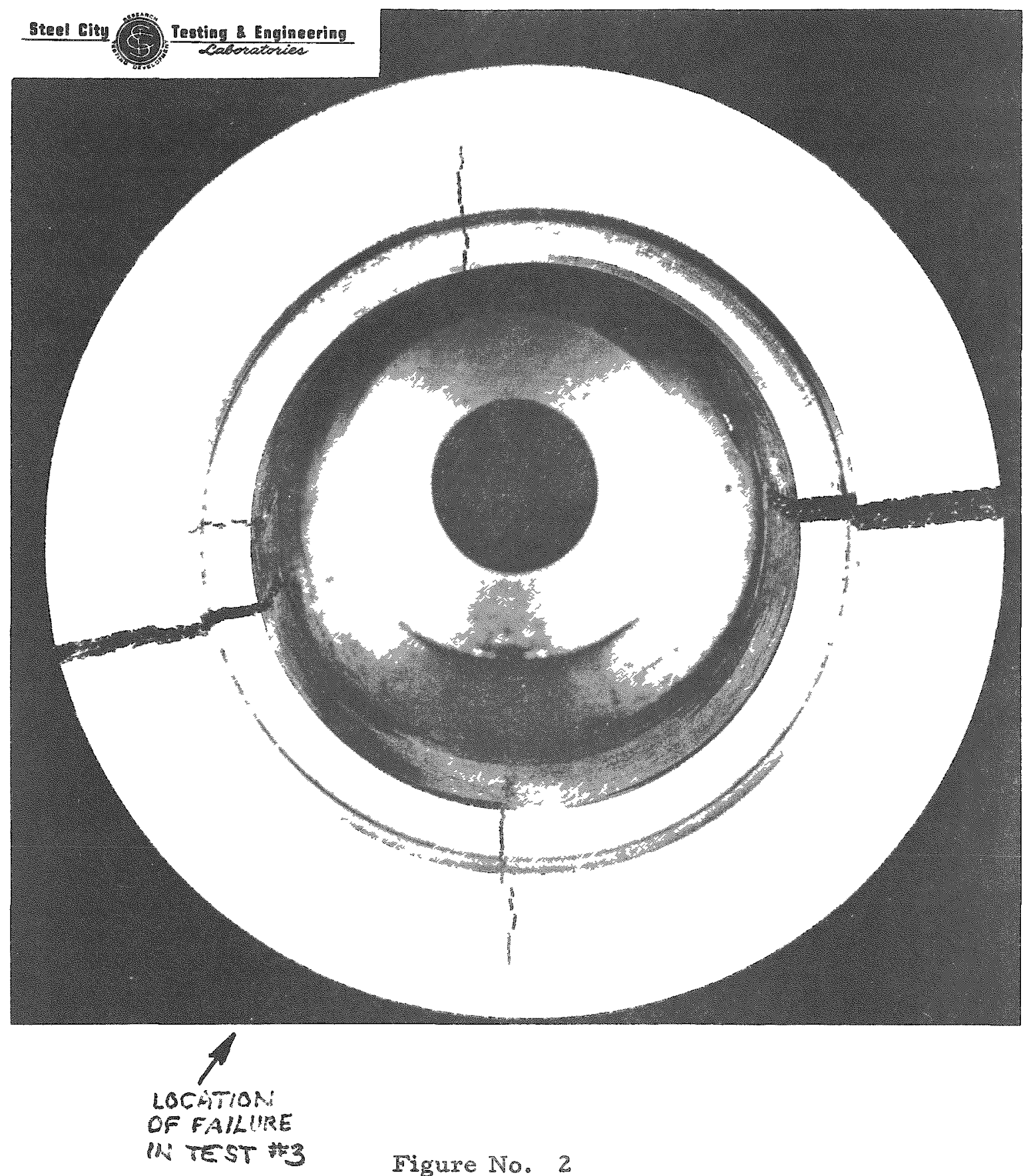

End view of failure 


\section{TEST 2}

F OR: Argonne National Laboratories

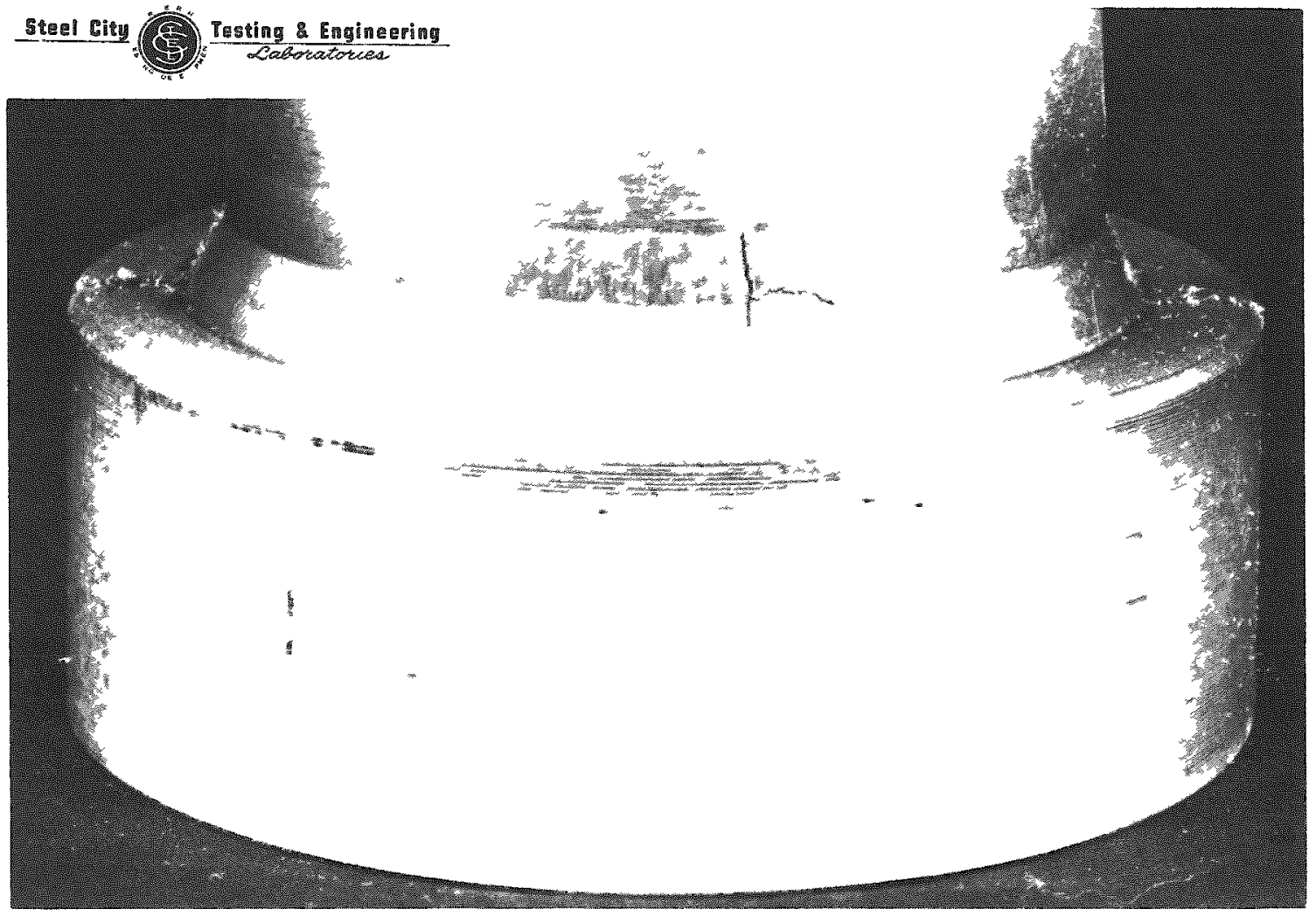

Figure No. 3

Side view of failure 
TEST \#2

FOR: Argonne National Laboratories

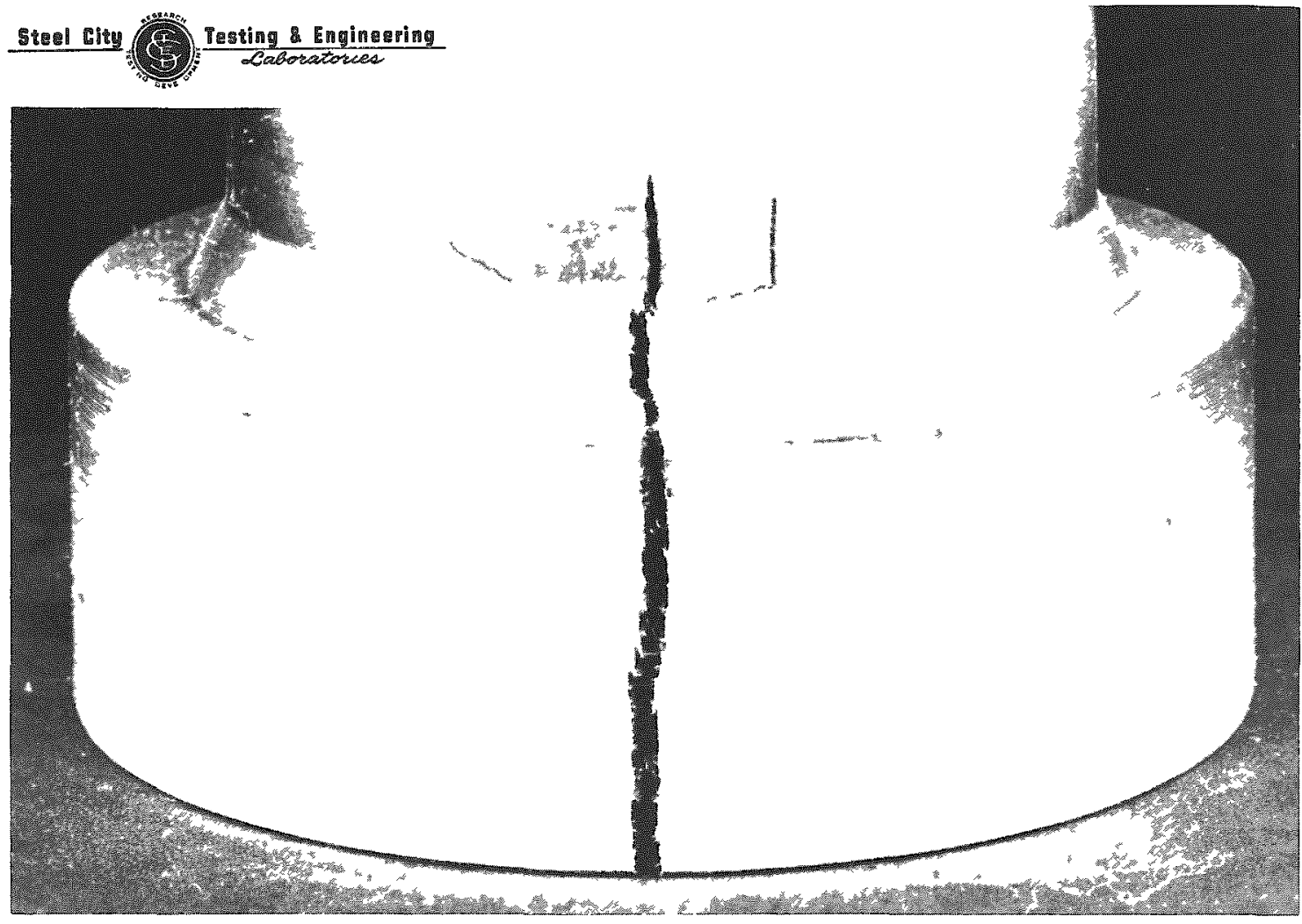

Figure No. 4

Side veiw of failure 


\section{FOR: Argonne National Laboratories}

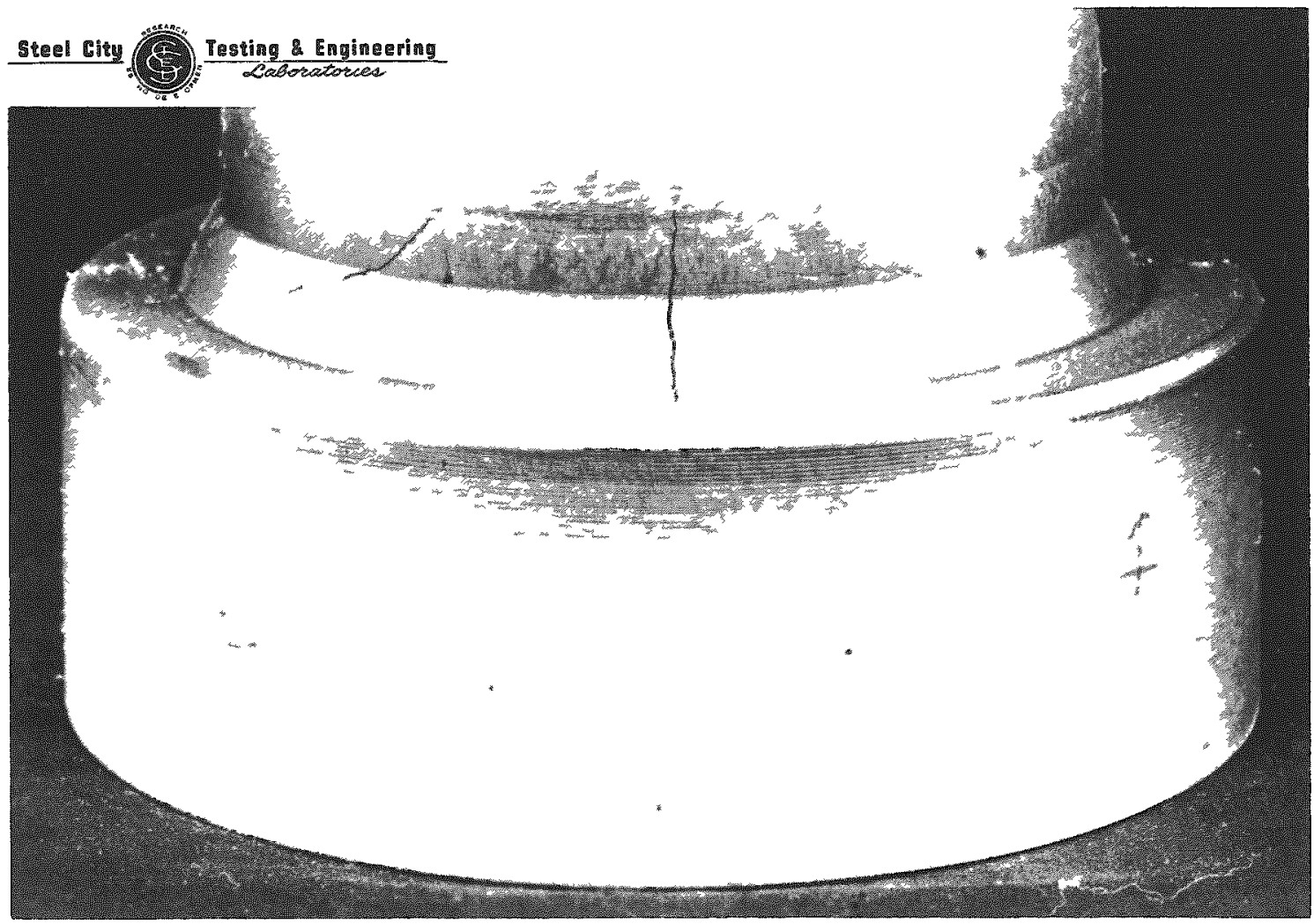

Figure No. 5

Side view of fallure 


\section{TEST \#2}

F OR: Argonne National Laboratories

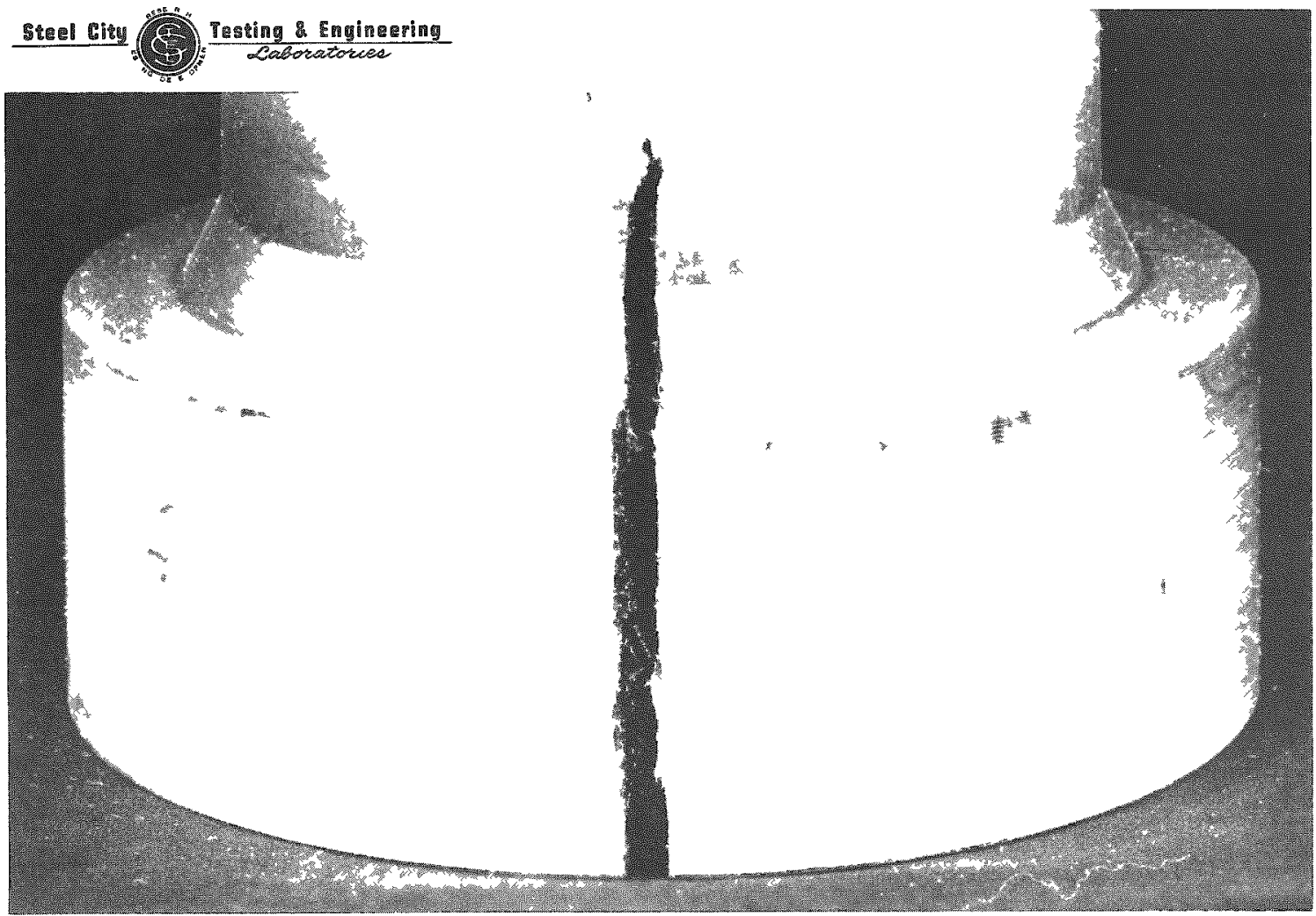

Figure No. 6

Side view of failure 
TEST \# 3

For: Argonne National Laboratory

steel ciity (6) Testing \& Engineering

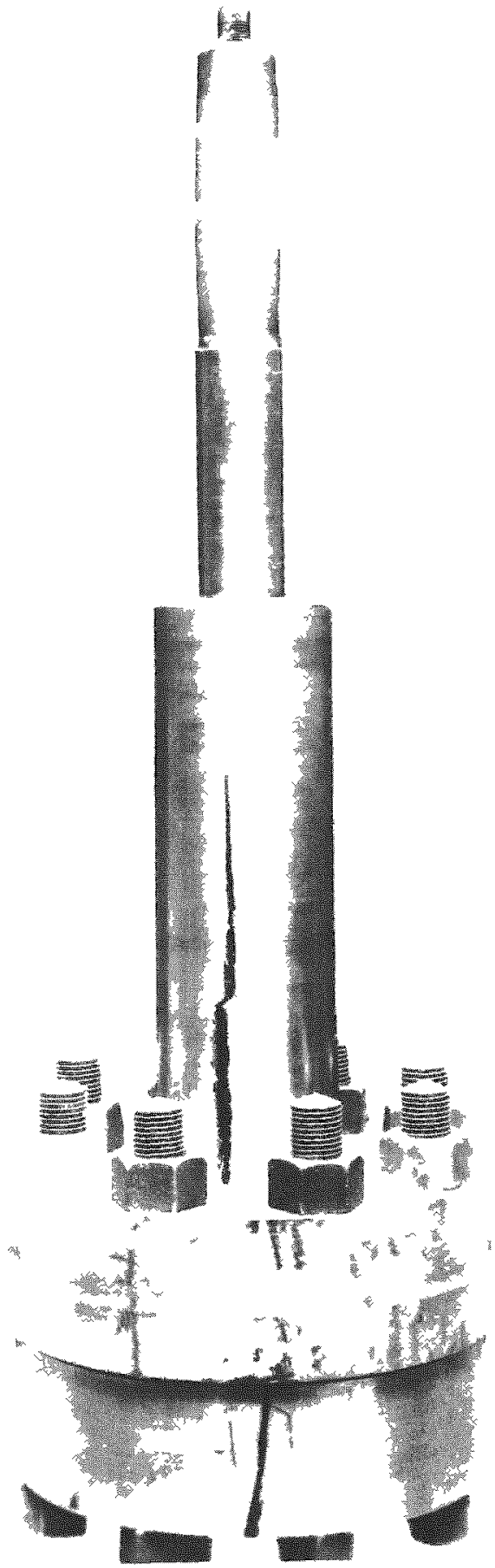

Figure No. 1

Side View 


\section{TEST TE TICHNICAL REPOT}

For: Argonne National Laboratory

Steel city $\sqrt{\text { (F) }}$ Iesting \& Engineering

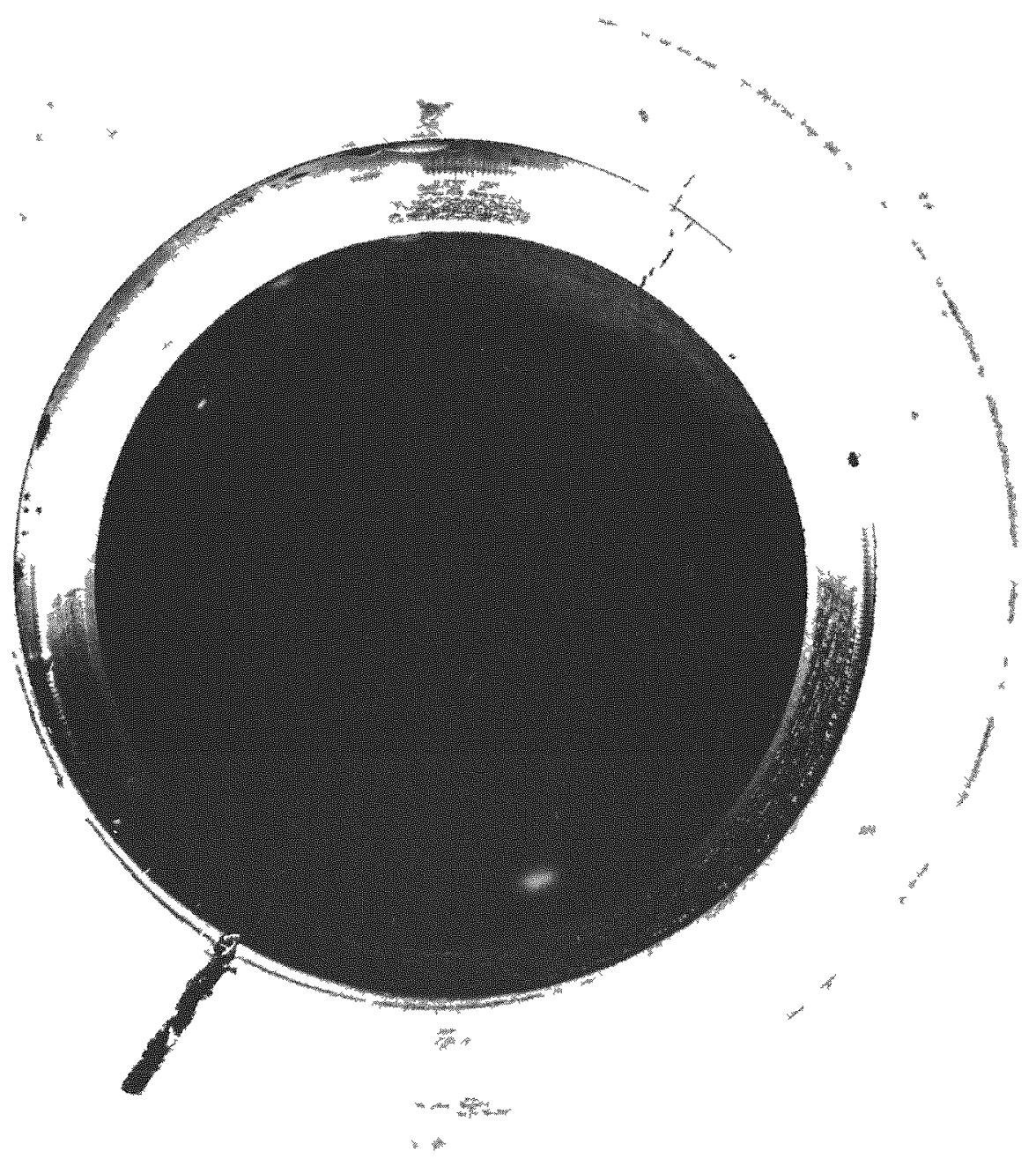

Figure No. 2

Bottom View - Disassembled 
For: Argonne National Laboratory

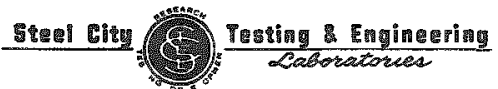

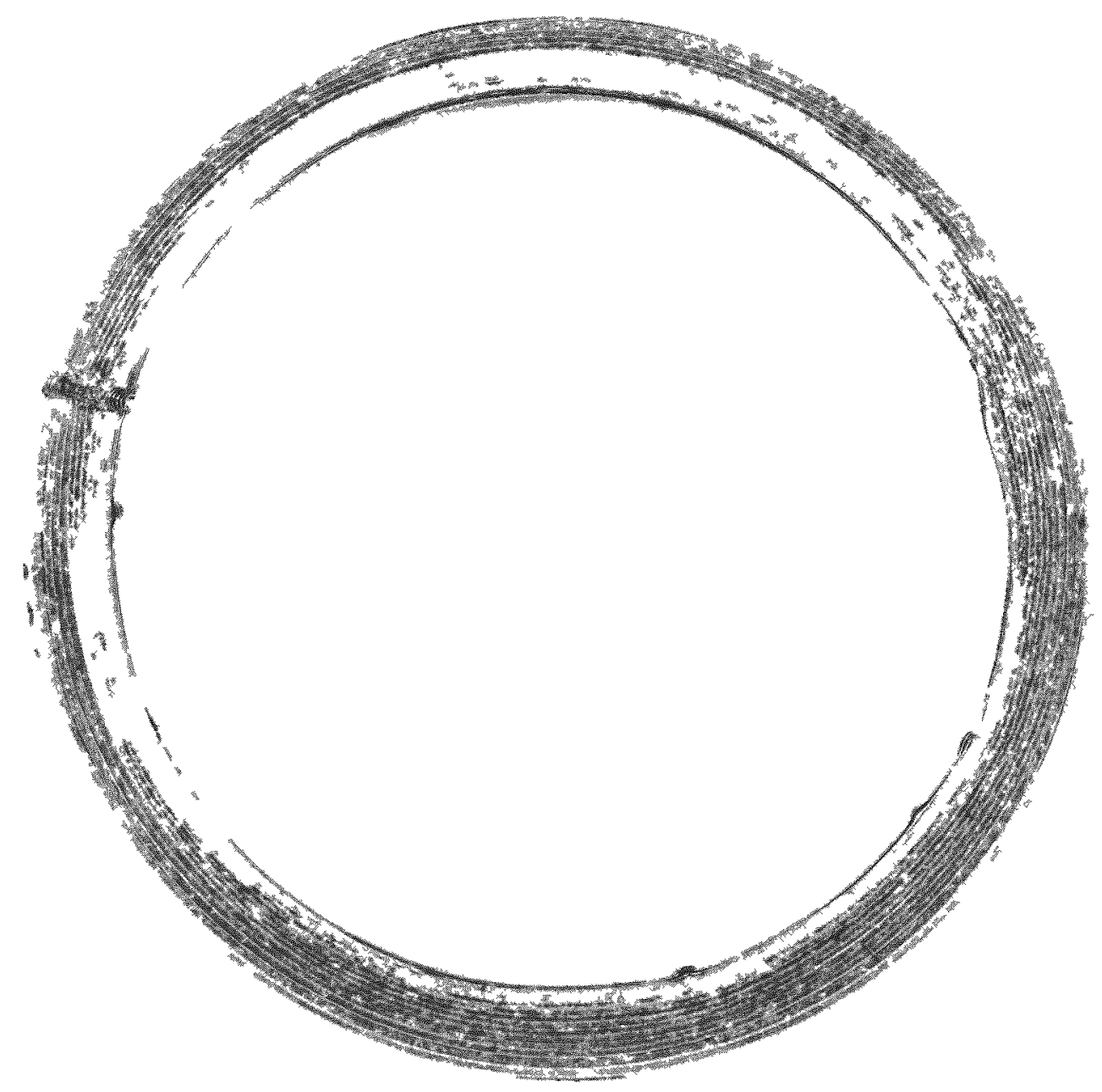

Figure No. 3

Flange and Gasket - Disassembled 
(4) 1. PRE-HEAT $300^{\circ}$ TO $350^{\circ} \mathrm{F}$

2. HELIARC WELD FIRST PASS $3 / 32$ DIA INCO-WELD A

3. ARC WELD OTHER PASSES WITH 1/8 DIA INCO-WELD "A"

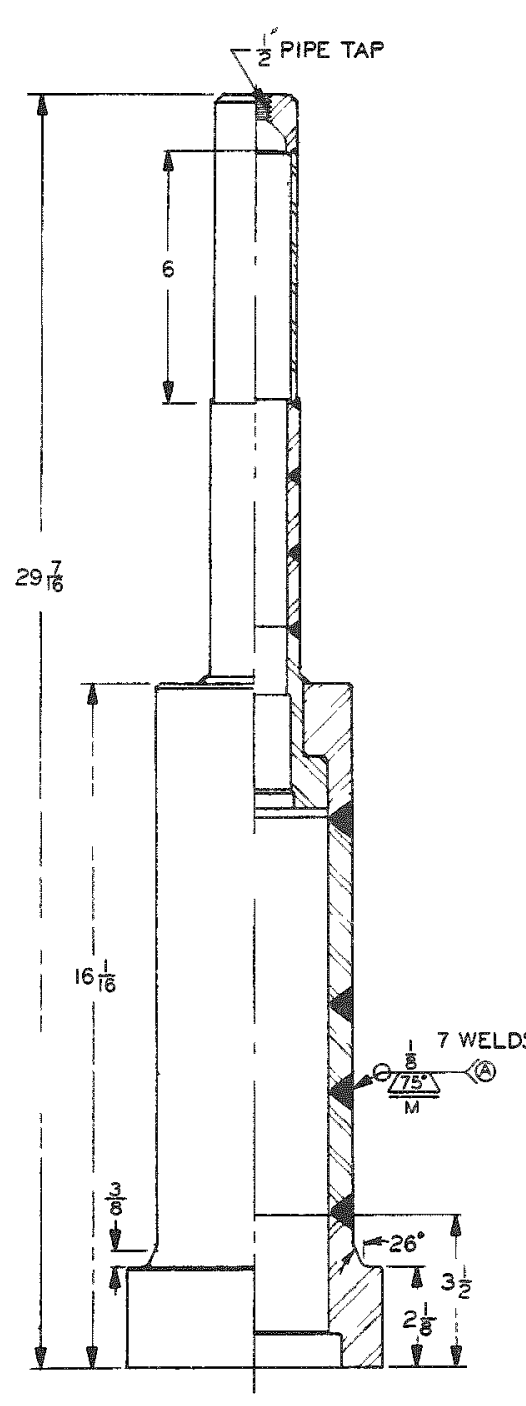

MODEL USED IN

TEST 1 है?

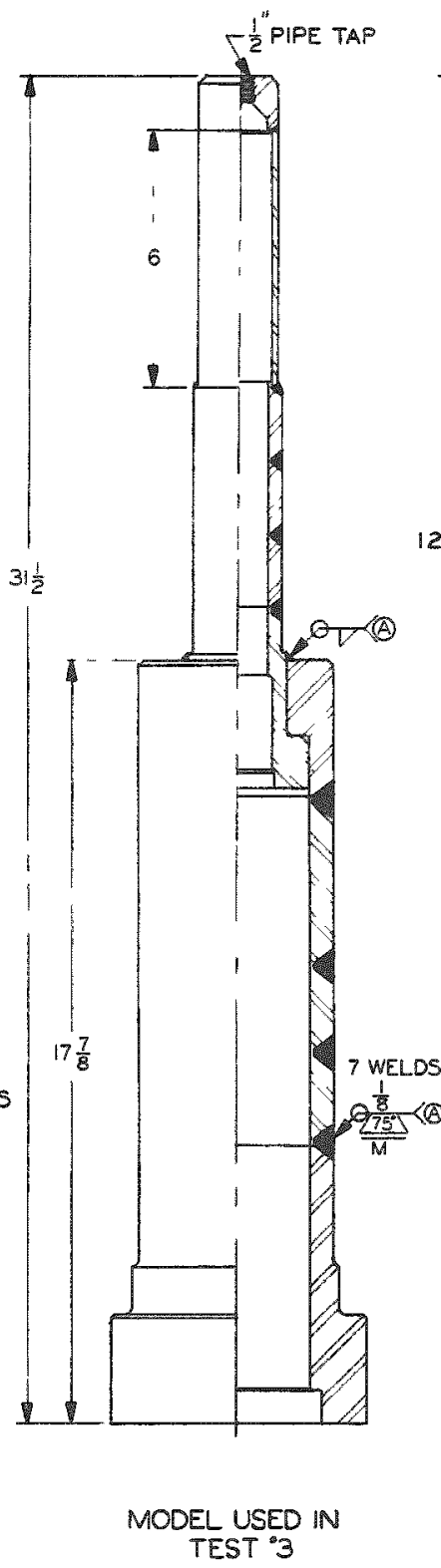

TEST ${ }^{\circ} 3$

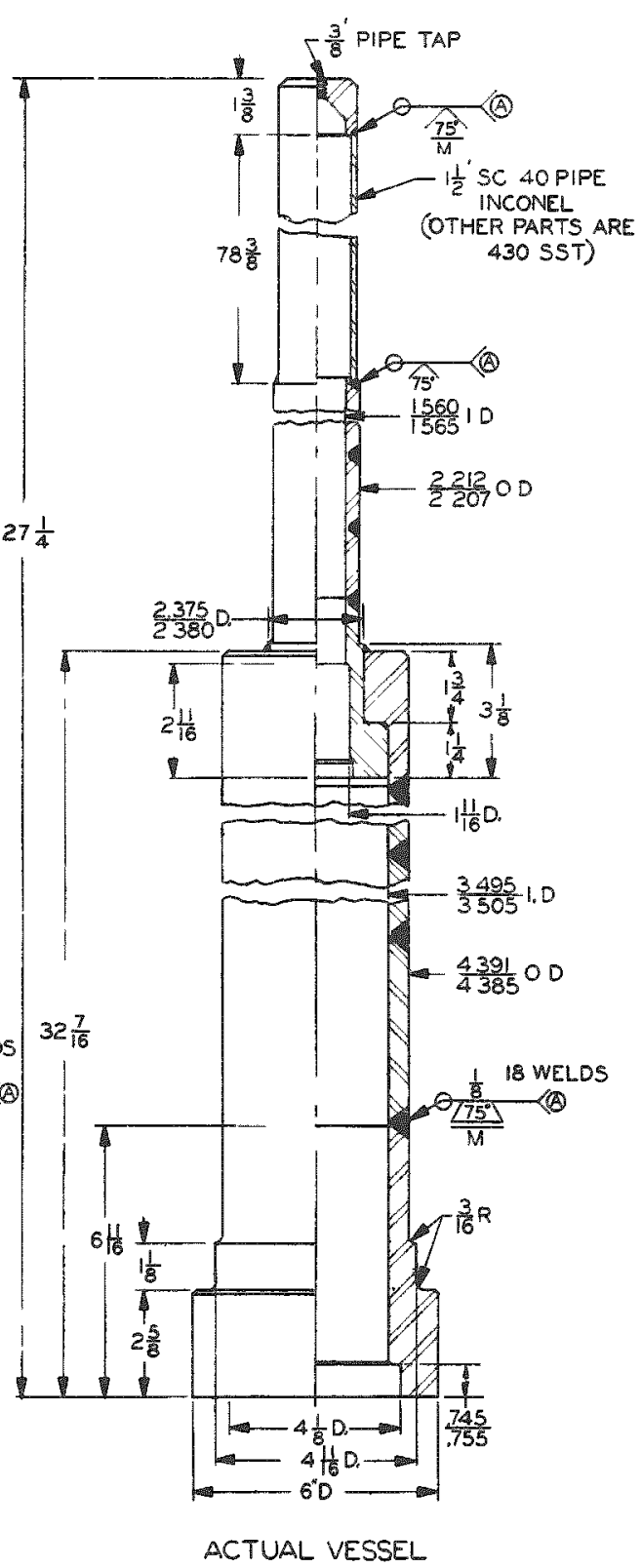




\begin{tabular}{|c|c|c|c|}
\hline $\begin{array}{c}\text { DETAIL } \\
\text { NO }\end{array}$ & NAME & \multicolumn{1}{|c|}{ MATERIAL } & NO \\
\hline 1. & NUT & $1-1 / 4-8$ STEEL & 16 \\
\hline 2 & STUB & I-1/4-8XII B-14 STEEL & 8 \\
\hline 3 & GASKET & $\begin{array}{l}\text { FLEXITALLIC"R3-25K, 304SST } \\
\text { AND A SBESTOS }\end{array}$ & 1 \\
\hline 4 & FLANGE RING & LOW CARBON STEEL & 1 \\
\hline 5 & BLIND FLANGE & LOW CARBON STEEL & 1 \\
\hline
\end{tabular}

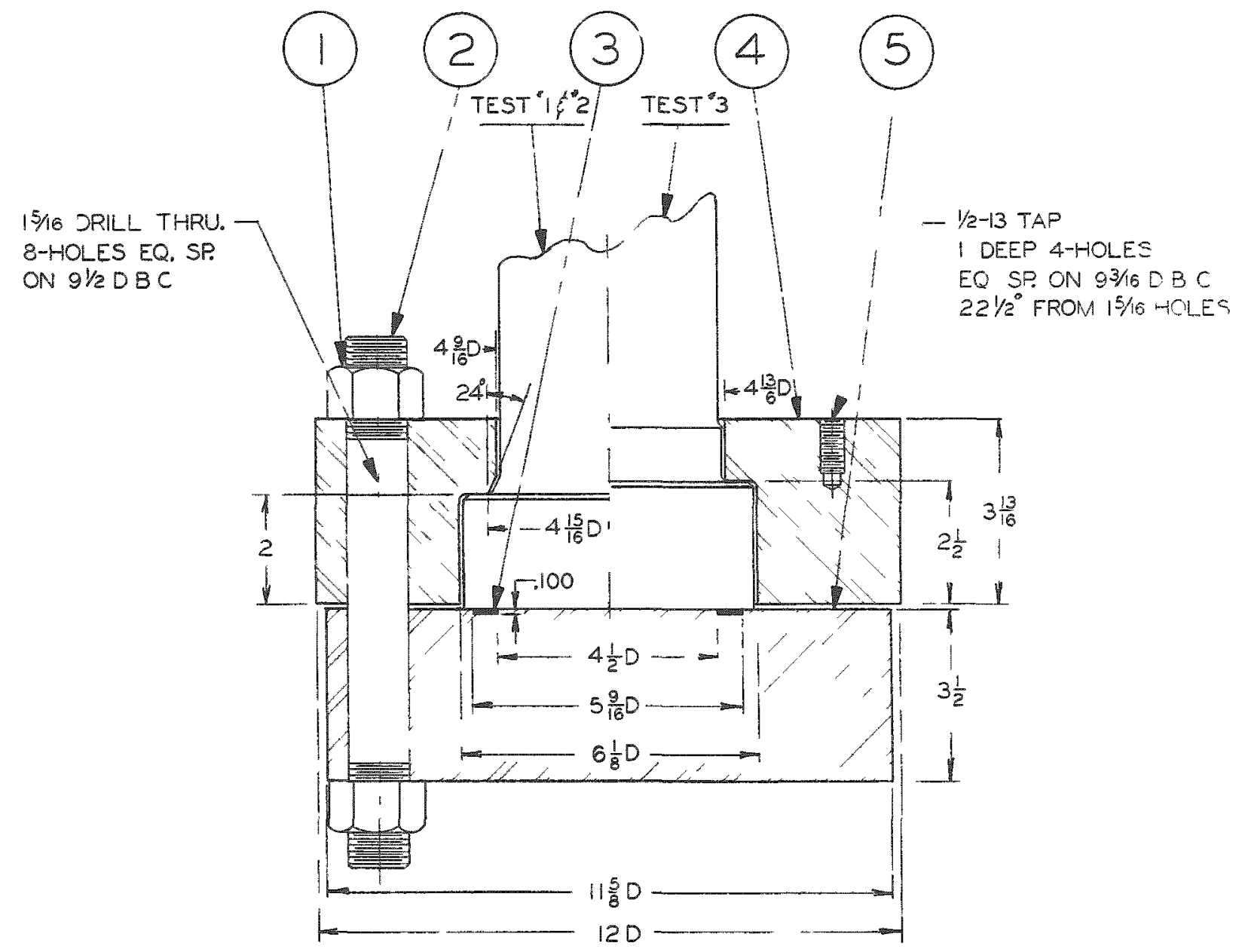

TEST MODEL FLANGE ASSEMBLY 


\section{INDEX}

Above the reactor drive, $9 *, 26 * 34$, also see Jack \#27, \#29H

Acknowledgement, 31*

ALPR jack drive, see Jack \#27

Antigravity-scram, 34 through 36

Armature, 14*, 38*, 55, 98, 108

Below the reactor drive, 9*, 26*, 34, also see Jack \#29 L

Capacity, 12 through 42

Chrome plating, 9*, 11

Clearance, 14*, 25*,90

Coils, connections for, $10,45,49,95$

magnet, 16*, 94, 46 through 49, 103, 104, 105

position indicator, $68,101,113$

test of, see Test results

Connection, coil, see Coils

control rod, 9, 58 through 66

pressure vesse1, *25, 14

Control, 16*17*, 18*, 11, 15, 71,72,73,80,81,82,88

Cooling 26*, 37 through $40,90,14,21$

Cost, 31*, 10,19

Cushion washers, 15*, 44*, 56, 102

Dash pot, 25*, 28 through 32,58

Decelerator, see Dash pot

Description, functional, 6*,8*, 9*, 10

Development, future, 22

since ANL-5768 was written, 10

Dirt, 29*, 11

Drives, other types of electromagnetic, $78 *, 80 *, 19$

Drive rod, $9 *, 44 *, 11,57,101,109$

EBWR jack drive, see Jack \#29L

Failure, 26*, 27*, 117 through 143

*ANL-5768; note that the parts list on page 35 of ANL -5768 should be on page 50 , and vice versa. 


\section{INDEX}

Friction, 9*, 15

Function of a control rod drive, 6*

High pressure jack drive, see Jack \#29H

Jack \#18B, 10*

Jack \#20,7*

Jack \#21E, 11*

Jack \#24, 12*

Jack \#27, 5, 41 through 57

Jack \#29H, 11,93,96,98 through 105

Jack \#29I, 11, 13,94,97,98 through 110

Life, 9*, 26*, 20,11,90

Load, 26*, 27*,28*, 90, 15

Magnetic circuit calculations, 67 through $77 *, 23$ through 27

Malfunctions, see Failure

Materials, 9*, 14*, 15*, 16*,70*, 128

Nonmagnetic sleeve, 14*, 45*, 11, 56, 102

Operation, see Description

Patents, 9

Performance, see Test results

Position indicator, 111,112

automatic digital type, 112

automatic meter type, 112, 118 through 121

coils, see Coils

comparative description, 112

decade switch type, 112,122 through 125

light and meter type, 20 through 24*, 112

light bulb type, 112, 114 through 117

linear scale meter type, 112,67 through $70,80,81,84,86$

test, see Test results

Power consumption, 26*, 27*,90 


\section{INDEX}

Power supply, 17*, 18*, 9, 11, 16, 71, 72, 74 through 81,89

Pressure, 26*, 127 through 146, 12, 42

Pressure shell design of, 15*, 16*,36*,37*,52,53,98, 99, 100, 106, 107, 127 through 146,21

test of, see Test results

Reversing, 9*,72

Safety, $27 *, 35,127$ through 146

Scram, 9*, 28*, 11, 34 through 37, 28 through 32

Selector, drive, 17*, 18*, 83

position indicator, 85

Size, 12, 19, 42

SL-1 jack drive, see Jack \#27

Slippage, 28*, 15, 19

Speed, 26*,28*, 11,71,90,22

Step length, 6*,26*, 10,56,71,90, 102

Summary, 10

Switch, coil sequencing, 20*,74,76,77,78,79,90

Temperature, 26*,28*,90,91,37 through 40,21, 18

Test results, jack, 5*, 25*, 26*, 15,90

magnet coil, 26*, 37 through 40

position indicator, 29*, 30*, 90

power supply, 90

pressure shel1, 127 through 146

Wear, $26 *, 29 *, 10$ 